\title{
Preliminary Technical Risk Analysis for the Geothermal Technologies Program
}

Technical Report NREL/TP-640-41156

March 2007

J. McVeigh and J. Cohen

Princeton Energy Resources International

M. Vorum, G. Porro, and G. Nix

National Renewable Energy Laboratory

NREL is operated by Midwest Research Institute Battelle Contract No. DE-AC36-99-G010337

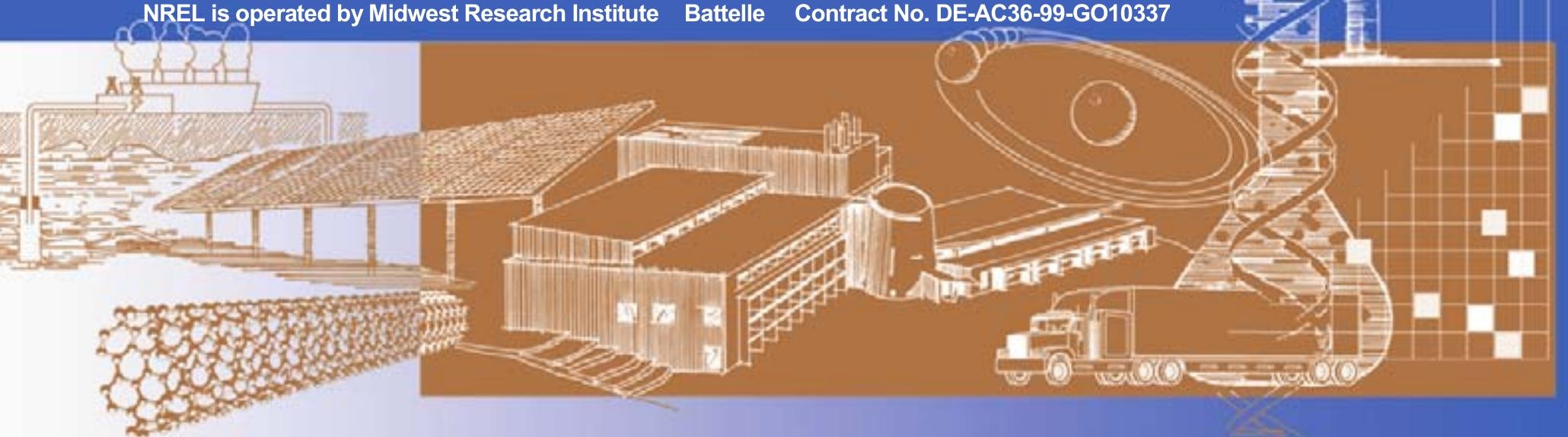


Preliminary Technical Risk Analysis for the Geothermal Technologies Program

J. McVeigh and J. Cohen

Princeton Energy Resources International

M. Vorum, G. Porro, and G. Nix

National Renewable Energy Laboratory

Prepared under Task No. GT04.1101
Technical Report NREL/TP-640-41156

March 2007

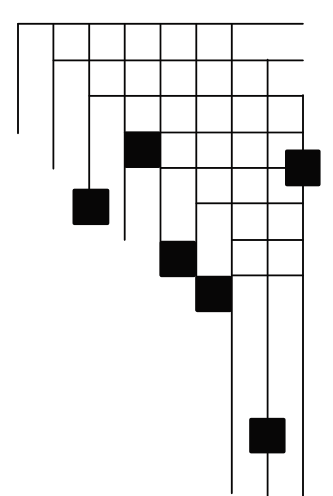




\section{NOTICE}

This report was prepared as an account of work sponsored by an agency of the United States government. Neither the United States government nor any agency thereof, nor any of their employees, makes any warranty, express or implied, or assumes any legal liability or responsibility for the accuracy, completeness, or usefulness of any information, apparatus, product, or process disclosed, or represents that its use would not infringe privately owned rights. Reference herein to any specific commercial product, process, or service by trade name, trademark, manufacturer, or otherwise does not necessarily constitute or imply its endorsement, recommendation, or favoring by the United States government or any agency thereof. The views and opinions of authors expressed herein do not necessarily state or reflect those of the United States government or any agency thereof.

Available electronically at http://www.osti.gov/bridge

Available for a processing fee to U.S. Department of Energy and its contractors, in paper, from:

U.S. Department of Energy

Office of Scientific and Technical Information

P.O. Box 62

Oak Ridge, TN 37831-0062

phone: 865.576 .8401

fax: 865.576 .5728

email: mailto:reports@adonis.osti.gov

Available for sale to the public, in paper, from:

U.S. Department of Commerce

National Technical Information Service

5285 Port Royal Road

Springfield, VA 22161

phone: 800.553.6847

fax: 703.605.6900

email: orders@ntis.fedworld.gov

online ordering: http://www.ntis.gov/ordering.htm 


\section{Table of Contents}

\section{$\underline{\text { Page }}$}

Executive Summary 1

Introduction 4

Summary of Method $\quad 5$

Consistency With Other DOE Risking Efforts 5

Challenges and Benefits of Risk Estimation and Interpretation 5

$\begin{array}{ll}\text { Conclusions } & 7\end{array}$

$\begin{array}{lc}\text { Recommendations } & 8\end{array}$

Risk Assessment Participants 9

The Geothermal Risk Analysis Team 9

The Geothermal Expert Team $\quad 9$

GETEM Reference Cases and Input Organization 11

The GETEM Model Reference Cases 11

The GETEM Model Input Variables 11

Geothermal Technology Improvement Opportunities 13

$\begin{array}{ll}\text { Risk Cases Considered } & 19\end{array}$

$\begin{array}{ll}\text { Geothermal Expert Team Scoring Matrices } & 19\end{array}$

Suggested Scoring Process for the Expert Team 27

$\begin{array}{ll}\text { MYPP Cases Scoring } & 27\end{array}$

Changes Made to Experts Inputs 28 
$\begin{array}{ll}\text { Summary of Results } & 30\end{array}$

Case-Specific Results $\quad 32$

Hydrothermal Binary 2010 Experts Case 33

Hydrothermal Flash 2010 Experts Case $\quad 35$

EGS Binary 2010 Experts Case 37

EGS Flash 2010 Experts Case $\quad 39$

EGS Binary 2040 Evolutionary Experts Case $\quad 41$

Hydrothermal Binary 2010 MYPP Case 43

EGS Binary 2010 MYPP Case $\quad 45$

Appendix A: Hydrothermal Binary Power System Case - Inputs A-1

Appendix B: Hydrothermal Flashed-Steam Power System Case - Inputs B-1

Appendix C: EGS Binary Power System Case - Inputs $\quad$ C-1

Appendix D: EGS Flashed-Steam Power System Case - Inputs $\quad$ D-1

Appendix E: Consensus Expert Team Scoring Matrices E-1

Appendix F: Cumulative Probability Distribution Functions of LCOE by Case F-1 


\section{Executive Summary}

This report introduces the development and first use of a management tool for risk analysis for the Geothermal Technologies Program (GTP, "the Program") of the U.S. Department of Energy (DOE). These first eight pages are an overview of a technical risk analysis task, leading into a presentation of comprehensive details of the task and its outcomes.

The analysis task developed a probabilistic, quantitative risk assessment of potential success of research goals for the Program. The goals are outlined in the Program's 2005 Multiyear Program Plan (MYPP).

As context, the focus here is on technical risk analysis. This sets a stage for a necessary evolution of Program risk analysis into other areas. Risk can be considered in forms such as:

$\begin{array}{ll}>\text { Technical risk } & >\text { Management risk } \\ >\text { Market risk } & >\text { Financial risk } \\ >\text { Political risk } & \end{array}$

Technical risk analysis estimates a degree and a certainty to which research and development (R\&D) work may fulfill goals of achieving technology improvements. Improvements may fall below, at, or above the goals. The approach used here expresses risk as pairs of values: a probability of success and a magnitude of technical effect or impact compared to a goal. The technical impact can be measured in terms of technology performance or its cost of utilization; and the probability is estimated as a percent likelihood of achieving the impact. Risk can further comprise one pair of values as a point estimate of risk, or be defined as a probability distribution function (PDF) comprising a range of varying impacts with respective probabilities of occurrence.

Across the DOE offices, efforts are under way to integrate methods for analyzing, managing, and communicating risk. This technical risk analysis task for the Geothermal Program can evolve toward adding capabilities - for example, in the aspect of management risk - to include risk analysis of Program budgets and schedules. Those topics would address needs such as predicting variations of outcomes that may result from R\&D work as functions of changes in budget or of schedules; and assessing tradeoffs in R\&D results due to competition among research lines for constrained budget resources. These are topics of future risk analyses.

Finally, each risk analysis task is one step in an iterative, ongoing cycle of progress management. This initial technical risk analysis has established a starting point as a template, which can be progressively filled in and expanded in risk-based reassessments of performance and goals. 
The technical risk analysis approach examines estimates of variable risks assigned to performance and economic benefits that may be achieved via Program research work. Risk results are expressed in terms of a key Program metric: levelized cost of energy ${ }^{1}$ (LCOE), and associated statistical information. This first analysis assumes a flat budget trend over the term of future performance estimates, at funding levels sufficient to accomplish the work scope projected in the Program's MYPP. That means that the risk team has considered technical challenges on the merits of being able to succeed in meeting goals in the projected time frames, but not on availability of $R \& D$ resources.

This preliminary analysis indicates that the Program is on course toward meeting its portfolio of economic and performance goals for the near-term target in 2010. For the longer-term goals, projected improvements in technology cost and performance present a narrow window of probability for success. Very important, the analysis provides data with which to prioritize performance levels that are critical to reach long-term success with improved certainty.

Specifically, the analysis employs a statistical sampling method using Monte Carlo simulation to drive a spreadsheet-based model named the Geothermal Electric Technology Evaluation Model (GETEM). GETEM is a techno-economic systems analysis tool for evaluating and comparing geothermal project cases. By itself, GETEM is a deterministic model; it computes LCOE values for a set of user-specified input variables that address about four dozen project criteria. A particular baseline geothermal project case is defined by allocating a profile of values to the input variables. A complementary feature of GETEM is an ability to examine "improved technology" cases derived from the baseline by applying potential benefits of research in terms of improvements to the baseline input variables. Each set of baseline and improvement data defines a profile of two related development cases. It compares the "present" with a conditional "future." By combining Monte Carlo sampling with GETEM as a risk model, it evaluates multiple ranges of potential impacts of $\mathrm{R} \& \mathrm{D}$, coupled with corresponding levels of probability of the occurrence of those impacts. The evaluation computes probability distributions of LCOE for geothermal power projects, rapidly assessing complex risk profiles for cases in great detail.

The R\&D impacts and probability distributions for this task were estimated by a risk team including independent experts, DOE laboratory researchers, and laboratory subcontractors. This GETEM-based risk analysis uses baseline data from the GTP Multiyear Program Plan (MYPP), and ranges of values of technology improvement opportunities ${ }^{2}$ (TIOs). The baseline values of GETEM input variables were adjusted to define cases for "improved technology" that reflect the risk team's estimates of improvements derived from the TIO values. Associated probabilities were proposed by the risk team. Combining the TIO inputs and probabilities enables the risk model to examine probabilistic implications of uncertain outcomes of technology R\&D on the

\footnotetext{
${ }^{1}$ The LCOE is a present value of a producer's cost of electricity for commercial and industrial power systems, usually named "busbar cost." It covers exploration, development, construction, and operating phases of a project. LCOE accounts for time-dependent values of equity, borrowed capital, operation and maintenance costs, and discounted values of other cash-flow terms such as taxes, insurance, escalation, etc.

${ }^{2}$ A TIO is simply a specific capacity, characteristic, component, or function of a technology that may be improved by R\&D. For the GTP context, it can be a remote exploration technique, a way of interpreting geologic data, a hightemperature electronics design for downhole drilling instruments, new materials for well casings, enhanced heat transfer surfaces for a power plant, a design of steam turbines to better withstand wet steam, etc. Project TIOs can be rolled up into higher-level TIOs as packaged, program-level research subjects.
} 
LCOE of generated electrical power. The calculated results give management a picture of the likelihood of achieving GTP research goals.

Starting with the MYPP baseline data, the team created profiles for seven risk cases. Table E1 summarizes the seven cases on their baseline LCOE values, the improved LCOE ranges (i.e., the minimum, mean, and maximum LCOEs determined by the risk analysis model), and the probabilities of meeting reduced LCOE values for each case. The "case year" identifies the year by which the improvements are expected to be achieved.

Table E1. Summary of LCOE Range and Probability of Meeting $5 \phi / \mathrm{kWh}$ Goal by Case

\begin{tabular}{|c|c|c|c|c|c|c|}
\hline \multirow{2}{*}{ Case and Year } & \multirow{2}{*}{$\begin{array}{c}\text { Baseline } \\
2005 \\
\text { LCOE }\end{array}$} & \multicolumn{3}{|c|}{$\begin{array}{l}\text { Improved-Case } \\
\text { LCOE Range }^{3}\end{array}$} & \multicolumn{2}{|c|}{ Probability of Meeting } \\
\hline & & Min & Mean & Max & $\begin{array}{c}5 \phi / \mathrm{kWh} \\
\text { Goal }\end{array}$ & $\begin{array}{c}\text { Mean LCOE } \\
\text { by Case Year }\end{array}$ \\
\hline \multicolumn{7}{|c|}{ Results of Expert Team Estimates } \\
\hline HT Binary 2010 & 8.54 & 3.80 & 4.73 & 6.13 & $75 \%$ & $54 \%$ \\
\hline HT Flash 2010 & 4.73 & 2.94 & 3.43 & 4.13 & $100 \%$ & $54 \%$ \\
\hline EGS Binary 2010 & 28.5 & 5.71 & 11.5 & 18.9 & $N / A^{4}$ & $51 \%$ \\
\hline EGS Flash 2010 & 29.3 & 8.39 & 15.6 & 23.0 & $\mathrm{~N} / \mathrm{A}$ & $53 \%$ \\
\hline Evolutionary EGS Binary 2040 & 28.5 & 3.85 & 6.29 & 13.8 & $14 \%$ & $59 \%$ \\
\hline \multicolumn{7}{|c|}{ Results of MYPP Estimates } \\
\hline HT Binary 2010 & 8.54 & 4.35 & 4.74 & 5.10 & $99 \%$ & $52 \%$ \\
\hline EGS Binary 2010 & 28.5 & 12.5 & 14.3 & 17.8 & $\mathrm{~N} / \mathrm{A}$ & $52 \%$ \\
\hline
\end{tabular}

To summarize some general conclusions from these numbers, the Program has good potential of achieving research goals to attain cost-effective power for hydrothermal systems in the 2010 time frame. This means that goals for hydrothermal technology development could be increased, in order to increase a scope of potential for growth in that industry sector.

EGS technologies have an almost $60 \%$ probability of achieving an LCOE of $6.3 \notin / \mathrm{kWh}$ by 2040 , closely approaching a Program goal of $5 \notin / \mathrm{kWh}$. Therefore, the R\&D plans should be examined to increase the composite probability of reaching the goal.

\footnotetext{
${ }^{3}$ The LCOE mean values in Table E1 are calculated as probability-weighted averages.

${ }^{4}$ Three EGS entries in Table 2 are labeled "N/A" (not applicable). This is because Program goals project that technology improvements under DOE research will make it possible for new, greenfield power development projects to attain LCOE values of $5 \mathrm{k} / \mathrm{kWh}$. This goal is further scheduled to occur by 2010 for hydrothermal resource power systems, and by 2040 for EGS power systems. Therefore, the EGS cases would not meet the $5 \notin / \mathrm{kWh}$ threshold by 2010.
} 


\section{Introduction}

This report explains the goals, methods, and results of a probabilistic analysis of technical risk for a portfolio of R\&D projects in the DOE Geothermal Technologies Program (The "Program"). The analysis is a task by Princeton Energy Resources International, LLC (PERI), in support of the National Renewable Energy Laboratory (NREL) on behalf of the Program.

The main challenge in the analysis lies in translating $R \& D$ results to a quantitative reflection of technical risk for a key Program metric: levelized cost of energy (LCOE). This requires both computational development (i.e., creating a spreadsheet-based analysis tool) and a synthesis of judgments by a panel of researchers and experts of the expected results of the Program's R\&D.

For the computational development, NREL requested that PERI develop a probabilistic risk analysis method to evaluate ranges of potential impacts of R\&D on LCOE for geothermal power development projects. The method uses Monte Carlo simulation in conjunction with GETEM, a recently developed systems analysis tool. GETEM is a deterministic model set up to evaluate one set of conditions at a time, comparing one baseline profile to one pattern of technology improvements as a case study. Each case study represents a development project with unique geologic, technical, and economic conditions. Adding a risk analysis capability to GETEM involves using a range (probability distribution) of input estimates to calculate probabilistic results for potential improvements to a case study baseline. For each risk case study, the Monte Carlo routines successively drive GETEM through the ranges of risk values for all improvements, called technology improvement opportunities (TIOs), that are considered. The model statistically tracks and integrates the calculated case outcomes as probability distribution functions (PDFs).

To estimate risk parameters, the Program invited a team of laboratory and independent, privatesector experts to guide a group of DOE researchers in a task of quantifying potential impacts and success probabilities of $\mathrm{R} \& \mathrm{D}$ activities in geothermal technology. The task addresses technologies ranging from exploration, to geology and resource assessment, to well drilling and energy conversion.

Program success is measured, in part, on R\&D results that enable industry to reduce LCOE by using improved geothermal technologies to generate electrical power. This new risk analysis activity provides the Program a capability to assess and manage "risk" inherent in its unique work. This is achieved by quantifying and integrating the discrete potentials - i.e., probabilities - that specific lines of R\&D may succeed, and the ranges of impacts that success may entail. Those values are used as inputs by the Monte Carlo/GETEM risk model to compute PDFs expressing LCOE vs. probability of occurrence.

As a result, this task provides the Program with a capability to examine research work and associated risk, as it is currently known. Furthermore, that capability will enable the Program to progressively track work success and work risk. It enables staff at all levels of the Program to quickly and consistently adjust future analyses of risk, based on evolving estimates of research impacts and corresponding success probabilities. 


\section{Summary of Method}

GETEM is a system model for analysis of performance and economics of geothermal power projects. It enables users to quickly examine variables that characterize complex geothermal power systems, and quantify profiles of project phases from exploration through operation. Applying GETEM as a computation engine in risk analysis, the subject of this activity, requires adding statistical sampling features to GETEM to implement Monte Carlo simulation. This computer programming task is coupled with profiling a particular set of cases and risk probability characteristics as the bases for a preliminary technical risk analysis.

This task is developmental by virtue of creating a GTP-specific risk analysis tool (i.e., GETEM coded with the Monte Carlo method integrated). For this development, the risk modeling uses a set of profiles for geothermal binary energy conversion case studies that are defined in the 2005 GTP Multiyear Program Plan (MYPP). Those cases, along with additional flashed-steam conversion cases defined for this analysis, serve as benchmarks from which to assess potential effectiveness of GTP research work.

This developmental process is being done specifically to provide data and analyses to the Program management team for the annual DOE budget process. More generally, the risk methods and tools resulting from this task will serve ongoing Program oversight work.

\section{Consistency With Other DOE Risking Efforts}

The method of assigning risk parameters to a program's R\&D work - ranges of estimated degree of change in project cost and performance, and the likelihood of it occurring - is a high-profile topic within the evolving DOE approach to risk. The approach taken in this GTP-specific risk analysis study is consistent with the current state of DOE methods except as noted below.

\section{Challenges and Benefits of Risk Estimation and Interpretation}

The practice of assigning risk parameters is a critical step in examining individual and integrated risks across Program disciplines. Assigning risk probabilities combines science, analysis, and judgment. The team of experts for this task was asked to judge potential successes of Program research at project levels, and to also estimate how to roll up those judgments to higher-level performance metrics that comprise the GETEM input variables. This approach poses a dual challenge of, first, estimating unknown research outcomes and, second, translating those outcomes into composite improvements and probabilities of success for the GETEM inputs.

While this dual challenge is well recognized for its difficulty, it offers a prospect of highly effective insight for Program management. In particular, this approach equips any management team with an ability to assess and manage tasks down their administrative chain with consistency, and to evaluate and communicate Program performance up the chain. 
Specification of risk parameters in this type of study enables comprehensive comparison of the prospective effectiveness of different research activities under a set of assumptions concerning funding. This comparison can shed light on the weight of each technical subject's relative risk compared to other discipline-specific successes or shortfalls.

This study does not completely address all aspects of uncertainty associated with geothermal electricity generation. Rather, the study is focused on understanding the impact of the uncertainty associated with the effectiveness of Program R\&D on lowering the levelized cost of electricity generation. Significant uncertainty is associated with the characterization of geothermal resources. This is a unique aspect of geothermal development when compared to other renewable technologies. Resource supply uncertainty is being reviewed in a separate, comprehensive study of geothermal technology. It would be fruitful to integrate the findings of that study, using this risk analysis methodology to provide a holistic understanding of all the major sources of uncertainty for geothermal electricity generation. As one example, a high level of uncertainty and consequent risk pertains to the assessment of geothermal resources that can be reliably and economically engineered to create Enhanced Geothermal Systems (EGS). These systems are characterized as heat reservoirs within geologic formations that may be artificially stimulated to increase naturally low permeabilities, resulting in fracture pathways that combine high flow rates and high energy recoveries using water circulation.

While the uncertainty of successful EGS reservoir stimulation should be considered in comparison to other technology disciplines (e.g., the wellfield construction and energy conversion subprograms), the uncertainty associated with the abundance of EGS-type geothermal resources was not considered in this study. 


\section{Conclusions}

The following conclusions are observations about the development of the risk methodology and its quantitative results. The results are particular outcomes of the case studies of this analysis, which was set up to specifically examine implications of the current GTP Multiyear Program Plan. Changing the input profiles for the cases would change the computed results and may lead to alternative conclusions. However, without this first step of evaluating MYPP risk, the results of other cases cannot logically be used to suggest changes to the MYPP. That reflects both the purpose and the consistency of the statistical risk analysis methods here. For details explaining and supplementing these general conclusions and the following recommendations, review the "Case-Specific Results" section on Page 32. In particular, the plots in Figures 2-15 give informative breakouts of discrete TIO impacts on LCOE.

C-1. The Program has good potential of achieving research goals of attaining cost-effective power for hydrothermal systems in the near-term 2010 time frame. This means that goals for hydrothermal technology development could be increased, in order to increase a scope of technical and economic potential for growth in that industry sector.

C-2. TIO levels that yield a mean LCOE of $6.3 \phi / \mathrm{kWh}$ for EGS technologies in 2040 have almost $60 \%$ probability of success. Further examination of modeling results indicates that, while outcomes from currently planned $R \& D$ have a probability of resulting in LCOE close to the $5 \mathrm{k} / \mathrm{kWh}$ Program goal, the probability may be lower than desired. Therefore, the R\&D plans should be closely examined to target objectives that increase the composite probability of reaching the goal. This illustrates a key benefit of quantifying probabilistic risk - developing data with which to rate and focus goals and tasks by uncertainties.

C-3. This preliminary risk analysis focuses on what is technologically possible for planned activities under future budgets with level funding, assuming that level of funding is adequate to complete the work. This protocol may complement future methods to address budget and schedule risk; the technical risk analysis can be expanded to look at variable funding and schedule scenarios. Such refined analysis will require additional data and model development to incorporate R\&D deliverables, effort, and budget.

C-4. The TIOs for EGS and exploration technologies contribute a small portion of projected improvements for Hydrothermal 2010 cases, but they become important for EGS 2010 cases and even more important for EGS 2040 cases. By 2040, the EGS and exploration TIO contributions to LCOE reductions are noticeably greater than drilling cost reductions, and also much greater than conversion impacts. Their value warrants strong consideration of focused research and resource allocations.

C-5. Energy conversion TIOs are important in the 2010 cases, but become less important in the 2040 cases, because EGS and exploration TIOs become more dominant. This suggests targeting the Program's strategy and tactics to capture conversion technology gains early; and, thereafter, just tracking the technology (with associated reduced budget allocations) into the mid- and long-term time frames. 
C-6. Although there are different timing and budget implications for the most effective realization of various TIOs, all TIOs are essential to capturing full long-term gains.

\section{Recommendations}

We recommend expanding the risk assessment activities to address these objectives:

R-1. Focus the MYPP on those research activities that offer best success of meeting the $5 \notin / \mathrm{kWh}$ LCOE target by 2040 for EGS systems.

R-2. Complete the mapping of the GTP work breakdown structure (WBS) with respect to potential impacts, i.e., incorporate other information to determine which research areas/tasks give the most "bang for the buck" and in what time frame. This provides a basis to optimize program strategy, tactics, and activities.

R-3. Investigate alternative budget, schedule, and competitive task funding scenarios.

R-4. Develop better drilling cost models, especially those that can account for short-term perturbations due to oil and gas drilling demands. This may be as simple as incorporating additional parameters into the cost models, such as a ratio of open drilling permit applications to the number of available drill rigs. This will allow for investigation of issues such as determining most probable depths for optimizing LCOE for EGS systems as a function of geologic temperature gradients.

R-5. Expand the technical risk analysis to include other resources, such as geopressured reservoirs and coproduction from oil and gas wells.

R-6. Finally, this implementation of GTP technical risk analysis should be proposed as a platform to update data used by the Energy Information Administration (EIA) for the National Energy Modeling System (NEMS) program and database. Risk projections can be coupled with geologic resource data to generate periodically updated supply curves of geothermal resources. A resource supply curve provides energy costs as a function of installed capacity, and the data can be regionalized, whereas NEMS now uses a matrix of nominally site-specific energy and cost data to represent the U.S. geothermal energy potential on a restricted geographic basis. Addressing the NEMS database would be fundamentally beneficial in the near term, because the geothermal data in NEMS now are understood to be outdated. Furthermore, EIA has initiated some interpretations of commercial geothermal development potential, and this risk analysis tool may provide leverage by which to collaborate with EIA in better representing geothermal potential for NEMS. Preliminary discussions with EIA in this vein have been favorably received.

Looking forward, by incorporating risk in the supply curve characterization of geothermal resources, the Program can support NEMS applications that also seek to incorporate risk into national economic modeling. 


\section{Risk Assessment Participants}

\section{The Geothermal Risk Analysis Team}

The Risk Analysis Team included Joe Cohen and Jim McVeigh of PERI; Gerry Nix, Gian Porro, and Martin Vorum of NREL; and Pat Quinlan of Sentech, Inc. This team was responsible for coordinating the efforts of the Geothermal Expert Team, as well as collecting the individual technology improvement estimates from each of the experts, compiling a consensus of the expert team estimates, and reporting on these estimates. Additionally, PERI was responsible for developing the Monte Carlo simulation coding, using the estimates to run the probabilistic risk analyses, and compiling the detailed results for this report to DOE.

PERI has extensive experience in designing and modifying probabilistic risk analyses models. For example, PERI had a lead role in developing the DOE Wind Technologies Program's Wind Pathways risk model. PERI also supports DOE staff in the development of guidelines for risk analysis that are evolving within the Office of Energy Efficiency and Renewable Energy (EERE) and other branches.

\section{The Geothermal Expert Team}

Table 1 lists the experts who participated in this process of planning and implementing risk analysis for the Program. The Geothermal Expert Team was convened to assess the potential impacts and attendant probabilities of success of the Geothermal Research Program's R\&D activities on technology performance and cost. Members of the team performed their assessments and reviewed the consensus estimates between March 15, 2006, and March 31, 2006. The team was divided into three technology subgroups: 1) EGS and Exploration, 2) Wellfield and Drilling, and 3) Energy Conversion.

Table 1. Experts Participating in the Geothermal Risk Analysis ${ }^{5}$

\begin{tabular}{|l|l|l|}
\hline \multicolumn{1}{|c|}{ Organization } & \multicolumn{1}{c|}{ Name } & \multicolumn{1}{c|}{ Subgroup } \\
\hline GETEM Development Team & & \\
\hline Sandia National Laboratory (SNL) & Chip Mansure & Wellfield/Drilling \\
\hline SNL & Steve Bauer & Wellfield/Drilling \\
\hline Livesay Consultants & Bill Livesay & Wellfield/Drilling \\
\hline Black Mountain & Susan Petty & EGS/Exploration \\
\hline Idaho National Laboratory (INL) & Greg Mines & Energy Conversion \\
\hline Advisers & & \\
\hline INL & & \\
\hline Lawrence Berkeley National Laboratory (LBNL) & Joel Renner & Carol Bruton \\
\hline LBNL & Bill Bourcier & EGS/Exploration \\
\hline SNL & Doug Blankenship & Energy Contion \\
\hline SNL & Wellfield/Drilling \\
\hline
\end{tabular}

\footnotetext{
${ }^{5}$ Includes participation in any of the teleconferences (including kickoff), submission of individual scoring, or review/comments on group scoring.
} 


\begin{tabular}{|l|l|l|}
\hline NREL & Keith Gawlik & Energy Conversion \\
\hline NREL & Gerry Nix & Energy Conversion \\
\hline Barber Nichols & Ken Nichols & Energy Conversion \\
\hline BIBB \& Associates Inc. & John Brugman & Energy Conversion \\
\hline $\begin{array}{l}\text { Energy and Geoscience Institute (EGI), University } \\
\text { of Utah }\end{array}$ & Joe Moore & EGS/Exploration \\
\hline EGI & Phil Wannamaker & EGS/Exploration \\
\hline EGS Inc. & Paul Brophy & EGS/Exploration \\
\hline Global Power Solutions & Gary McKay & Energy Conversion \\
\hline Graphic Vision & Kathy Enedy & EGS/Exploration \\
\hline MIL-TECH UK Ltd & Roy Baria & EGS/Exploration \\
\hline Halliburton & Porter Underwood & EGS/Exploration \\
\hline Massachusetts Institute of Technology (MIT) & Jeff Tester & EGS/Exploration \\
\hline Ormat Technologies, Inc. & Daniel Schochet & Energy Conversion \\
\hline Software Enterprises Inc. & Ralph Veatch & EGS/Exploration \\
\hline The Industrial Company (TIC) & Richard Campbell & Energy Conversion \\
\hline University of Massachusetts Dartmouth (Retired) & Ron DiPippo & Energy Conversion \\
\hline Unocal (Retired) & D. Stephen Pye & Wellfield/Drilling \\
\hline
\end{tabular}


The remaining sections detail the bases, planning, and implementation of the risk analysis method. Results that are summarized above are described in detail below.

\section{GETEM Reference Cases and Input Organization}

\section{The GETEM Model Reference Cases}

It is important to note that the cost and performance inputs in GETEM define a number of site and project characteristics, namely the temperature, type, and depth of the resource; and the type of energy conversion system. The Risk Analysis Team, with guidance from the GETEM Development team, assigned case-study baselines for the analysis using multiple "Reference Cases." The Reference Cases were developed as performance benchmarks for the GTP Research Program. The following four cases are the Reference Cases from which improvements in technology cost and performance were projected.
1. Hydrothermal Binary ${ }^{6}$
2. Hydrothermal Flash
3. EGS Binary Shallow ${ }^{7}$
4. EGS Flash Deep

\section{The GETEM Model Input Variables}

For this analysis, the input variables and calculated values on the GETEM model input sheets (see Appendices A through D) are defined as belonging to one of the four following categories:

a. Plug Values - Inputs that remain fixed for the risk analyses and do not change regardless of "case" specification or as a result of $R \& D$.

b. Case Defining Plug Values - Inputs that define each "case" and were varied between cases, but are not used within a case to define R\&D improvements.

c. Model Calculations - performance and cost values that the model calculates; these were not varied by the experts, and could change as a result of changes in other inputs.

d. Research-improved Technology Performance Metrics (TPMs) - inputs that are "risked," or statistically sampled, by applying a distribution of improvements from R\&D that were estimated by the Geothermal Expert Team.

DOE EERE is developing a risk analysis methodology that defines TPMs as measures of a technology's performance or costs that can be used both to track program performance and to specify improvements projected for the Program's research efforts. For purposes of this analysis, the TPMs are a subset of the inputs to the GETEM model.

The GETEM-based risk analysis uses the baseline data and ranges of improvements from the TIOs to examine probabilistic impacts of technology changes on the LCOE of generated electrical energy. The results portray ranges of probabilities of meeting the GTP research goals. GETEM estimates LCOE for geothermal power projects. In GETEM, a user assigns input values

\footnotetext{
${ }^{6}$ Corresponds to a reference case used to estimate Program research in the MYPP.

7 Ibid.
} 
to a profile of parameters to define geothermal resource development projects. Each time the GETEM program file (an Excel spreadsheet) is saved, it uniquely defines a case that comprises a profile of "baseline" parameter values. The model is configured to give the user a comparison of the "baseline" case with an "improved" case, such that the input parameters can uniquely and simultaneously be varied toward different goals. The goals may include reducing capital costs, examining varying resource decline implications, and increasing equipment performance characteristics, etc. The GETEM code is configured such that power conversion systems are separately defined, depending on the user's application of either flashed-steam technology or binary energy conversion systems.

The GETEM Development Team was responsible for establishing the baseline parameters (i.e., the current cost and performance parameters of the technology). The Geothermal Expert Team was responsible for estimating ranges of improvements that may result from the TIOs, as well as probabilities of success of these improvements (i.e., the probability that GTP R\&D will result in a non-zero level of improvement, as defined by the improvement range).

Appendices A through D list the GETEM model inputs, broken out by the input categories listed on the preceding page, and showing the baseline input data for Hydrothermal Binary, Hydrothermal Flash, EGS Binary and EGS Flash technologies, respectively. The baseline GETEM inputs are taken from the Reference Case runs used in the MYPP. The Expert Team was not asked to comment on the baseline values. However, the experts were asked to suggest revisions and their rationales if they thought the baseline numbers should be altered.

As shown in the appendices, the GETEM model includes more than 50 individual inputs. The input categories are similar for the Binary and Flash Technology cases, although slight differences exist in some of the individual inputs. Table 2 lists the subset of GETEM inputs that were selected as TPMs for this risk analysis, and for which the Geothermal Expert Team was asked to estimate ranges and probabilities of improvement impacts.

Table 2. TPM Subset of the GETEM Model Inputs

\begin{tabular}{|l|l|}
\hline GETEM Inputs/TPMs & \multicolumn{1}{c|}{ Units } \\
\hline Utilization Factor & $\%$ \\
\hline Brine Effectiveness & Watt-hour / pound \\
\hline Plant Cost & $\$ /$ kilowatt $(\mathrm{kW})$ \\
\hline Production Well Cost & $\$ 1,000 /$ well \\
\hline Injector Well Cost & $\$ 1,000 /$ well \\
\hline Surface Equipment Cost & $\$ 1,000 /$ well \\
\hline Exploration Success & Ratio \\
\hline Confirmation Success & Ratio \\
\hline Stimulation Cost & $\$ 1,000 /$ well \\
\hline Production Well Flow Rate & gallons per minute / well \\
\hline Temperature Drawdown Rate & $\% /$ year \\
\hline Annual O\&M Nonlabor & $\%$ \\
\hline Number of O\&M staff & $\#$ \\
\hline
\end{tabular}




\section{Geothermal Technology Improvement Opportunities}

The TIOs are the specific ways that program R\&D can improve geothermal technology to affect the LCOE. To remain consistent with the developing DOE EERE Risk Analysis approach, we are using the TIO terminology instead of the Geothermal Program's term, technology improvement potential (TIP), but these are the same entities.

There are 75 individual TIOs identified by the Program, which have been grouped into 23 TIO Roll-ups by the GETEM Development Team. The 23 TIO Roll-ups are shown in Table 3 and are listed on the Geothermal Expert Team Scoring Matrices.

The full TIO list, provided by NREL, is shown in outline format following Table 3. 
Table 3. Technology Improvement Opportunity Roll-ups

\begin{tabular}{|c|c|c|c|c|}
\hline $\begin{array}{l}\text { TIO } \\
\text { No. }\end{array}$ & TIO Roll-up Name & TIO Description & $\begin{array}{l}\text { Technology } \\
\text { Subgroup }\end{array}$ & $\begin{array}{l}\text { TIOs } \\
\text { Included* }^{*}\end{array}$ \\
\hline 1 & Target Temperature Prediction & Increase accuracy of target temperature prediction & EGS/ Exploration & 1.1 .1 \\
\hline 2 & Fractures, Proppants, Rheology & Improve fracture methods, proppants, and rheology & EGS/ Exploration & 1.2 .1 \\
\hline 3 & Fracture Control/Packers & $\begin{array}{l}\text { Control of fracturing - new and improved borehole } \\
\text { packers }\end{array}$ & EGS/ Exploration & 1.2 .2 \\
\hline 4 & Fracture Prediction Modeling & $\begin{array}{l}\text { Develop numerical models that accurately predict } \\
\text { fracture growth and permeability development }\end{array}$ & EGS/ Exploration & 1.2 .3 \\
\hline 5 & Subsurface Circulation System & $\begin{array}{l}\text { Ability to create a subsurface circulation system as } \\
\text { designed }\end{array}$ & EGS/ Exploration & 1.2 .4 \\
\hline 6 & $\begin{array}{l}\text { Reservoir Performance } \\
\text { Modeling }\end{array}$ & $\begin{array}{l}\text { Develop numerical models that explain and extend } \\
\text { reservoir performance }\end{array}$ & EGS/ Exploration & 1.3 .1 \\
\hline 7 & Artificial Lift & Improve artificial lift technology & EGS/ Exploration & 1.3 .2 \\
\hline 8 & Short Circuit Mitigation & Improve short-circuit mitigation methods & EGS/ Exploration & 1.3 .3 \\
\hline 9 & Technical Systems Analysis & Perform systems analysis and integration & EGS/ Exploration & $\begin{array}{c}1.4 .1,1.4 .2 \\
1.5 .1\end{array}$ \\
\hline 10 & Remote Sensing & $\begin{array}{l}\text { Remote sensing exploration methods (InSAR, } \\
\text { hyperspectral imaging, GPS) }\end{array}$ & EGS/ Exploration & 2.1 \\
\hline 11 & Geophysics & $\begin{array}{l}\text { Geophysical exploration methods (seismic, } \\
\text { magnetotellurics) }\end{array}$ & EGS/ Exploration & 2.2 \\
\hline 12 & Geochemistry & Geochemical exploration methods (isotopes, gases) & EGS/ Exploration & 2.3 \\
\hline 13 & Resource Assessment & $\begin{array}{l}\text { National geothermal assessment and supply (EGS, } \\
\text { hydrothermal) }\end{array}$ & EGS/ Exploration & 2.4 \\
\hline 14 & Drilling Time Reduction & $\begin{array}{l}\text { Reduction of drilling time and expense, especially in hard } \\
\text { abrasive formations }\end{array}$ & Wellfield/ Drilling & $\begin{array}{c}3.9 .1-3.9 .3 \\
3.10 .2 \\
3.11 .2 \\
3.11 .4\end{array}$ \\
\hline 15 & Wellbore Lining Reduction & $\begin{array}{l}\text { Reduction of time and expense to line the wellbore } \\
\text { (including using less material and less costly material) }\end{array}$ & Wellfield/ Drilling & $\begin{array}{c}3.8 .1,3.8 .2 \\
3.11 .3 \\
3.12 .1 \\
\end{array}$ \\
\hline 16 & Flat Time Reduction & Reduction of nonessential flat time & Wellfield/ Drilling & 3.10 .1 \\
\hline 17 & $\begin{array}{l}\text { Instrumentation, Testing, } \\
\text { Simulation }\end{array}$ & $\begin{array}{l}\text { Development of basic information through analysis and } \\
\text { simulation efforts. }\end{array}$ & Wellfield/ Drilling & $3.1-3.6$ \\
\hline 18 & Completion and Production & Completion and production-related development projects & Wellfield/ Drilling & $3.7,3.11 .1$ \\
\hline 19 & Cycle Related & Cycle Related & Energy Conversion & $4.1 .1-4.1 .5$ \\
\hline
\end{tabular}




\begin{tabular}{|c|l|l|c|c|}
\hline $\begin{array}{c}\text { TIO } \\
\text { No. }\end{array}$ & \multicolumn{1}{|c|}{ TIO Roll-up Name } & \multicolumn{1}{|c|}{ TIO Description } & $\begin{array}{c}\text { Technology } \\
\text { Subgroup }\end{array}$ & $\begin{array}{c}\text { TIOs } \\
\text { Included }\end{array}$ \\
\hline 20 & Component Related & Component Related & Energy Conversion & $4.1 .6-4.1 .9$ \\
\hline 21 & Monitoring and Scaling & Monitoring and Scaling & Energy Conversion & 4.10 \\
\hline 22 & Design/Construction Related & Design/Construction Related & Energy Conversion & $4.11-4.13$ \\
\hline 23 & Automation/Enhanced Controls & Automation/Enhanced Controls & Energy Conversion & 4.14 \\
\hline
\end{tabular}

* The individual TIOs are listed in more detail on the following pages. 
The full TIO list for the Program is shown below, as provided by NREL:

\section{TIOs for Enhanced Geothermal Systems}

\subsection{Resource Characterization and Exploration}

1.1.1. Increase accuracy of target temperature prediction. Gradient and heat-flow data over entire United States at data density needed for firm conclusions of EGS potential

\subsection{Reservoir Design and Development}

1.2.1. Improved fracture methods, proppants, and rheology for EGS reservoirs

1.2.2. Control of fracturing in EGS reservoirs New and improved borehole packers, especially open-hole packers, for isolation of stimulation zones

1.2.3. Develop numerical models that accurately predict fracture growth and permeability development as a function of stimulation options and reservoir properties

1.2.4. Ability to create a subsurface circulation system as designed, and to control fracture growth and patterns for optimum fluid contact area and volume

\subsection{Reservoir Operation and Management}

1.3.1. Numerical models that explain reservoir performance and reliably extend predictions of performance into the future

1.3.2. Artificial lift technology - artificial lift equipment and methods with flexible setting depths, which can produce $200^{\circ} \mathrm{C}$ fluid at target flow rate of $54 \mathrm{~kg} / \mathrm{s}$ for at least 1 year

1.3.3. Improved short circuit mitigation methods - successful short-circuit control for temperatures up to $200^{\circ} \mathrm{C}$

\subsection{Systems Analysis}

1.4.1. Assemble, analyze, and interpret pertinent information on technologies relevant to EGS development from worldwide EGS research, petroleum reservoir development, mining operations, and other appropriate sources

1.4.2. Robust economic models to help guide EGS research and development

\subsection{Technology Transfer}

1.5.1. Collaborative relationships with industries large enough to move EGS development forward at desired rates to reach the 2040 goals. Involve at least one major energy company in the EGS Program by 2009

\section{TIOs for Exploration}

\subsection{Remote Sensing}

2.1.1. Show utility of InSAR for remote detection of systems

2.1.2. Integrate hyperspectral imaging with geophysical data

2.1.3. Show utility of GPS in detecting candidate sites

2.1.4. Improve modeling of permeability using remote sensing data

\subsection{Geophysics}

2.2.1. Improve resolution of magnetotellurics (controlled source audio, computer analysis)

2.2.2. Improve resolution of seismic (high frequencies, VSP, 3-D)

2.2.3. Integration of geophysical techniques (joint inversion modeling)

\subsection{Geochemistry}

2.3.1. Verify use of isotopes for identifying fluid source and deep permeability

2.3.2. Verify use of gases to identify hidden geothermal systems

2.3.3. Couple isotope and geochemistry data in transport models

2.3.4. Correlate geochemical interpretation with geophysical and geologic models 


\subsection{National Geothermal Assessment}

2.4.1. Updated national geothermal assessment including EGS

2.4.2. Develop a supply curve for hydrothermal systems based on U.S. Geological Survey (USGS) assessment

2.4.3. Develop a supply curve for EGS based on USGS assessment

2.4.4. Maintain exploration data

\section{TIOs for Wellfield Construction}

\subsection{Systems Analysis}

3.1.1. Cost model predicting the impacts of drilling technology improvements (input into greater $\notin / \mathrm{kWh}$ model).

\subsection{Numerical Simulation}

3.2.1. Rock/bit interactions understanding

3.2.2. Drilling instability understanding

3.2.3. Drilling system performance and reliability understanding

\subsection{Laboratory Testing}

3.3.1. Drilling Dynamics Simulator capabilities

3.3.2. Autoclave testing capabilities

\subsection{Field Testing}

3.4.1. Field validation tests successfully supporting smart development efforts

\subsection{High-Temperature Electronics}

3.5.1. Successful demonstrations of geothermal tool electronics

3.5.2. Increased availability of high-temperature services to the geothermal industry

\subsection{Development of Advanced Diagnostics}

3.6.1. Diagnostics While Drilling (DWD) availability and functionality in geothermal temperature regimes

3.6.2. Increased bit life through real-time trouble avoidance

3.6.3. Mean-time to Failure of DWD system electronics

3.6.4. Adaptation of non-wireline telemetry technologies for DWD

3.6.5. Flat-time reduction

3.6.6. Adaptation of DWD capabilities to support new drilling technologies

3.6.7. Real-time telemetry/look-ahead technologies to locate and drill to targets cost effectively.

\subsection{Engineering the Needed Infrastructure}

3.7.1. Commercially available high-temperature electronics components (a gauge of the number of new high-temperature component manufacturers)

\subsection{Well Design}

3.8.1. Well designs optimizing steel and cement use through site-specific analyses

3.8.2. Well designs minimizing steel through lean designs (e.g., monobore technology)

\subsection{Rock Reduction and Removal}

3.9.1. Rate of Penetration - granite (ROP)

3.9.2. Bit life (run distance)

3.9.3. Normalized rock reduction cost

\subsection{Wellbore integrity}

3.10.1. Flat-time reduction

3.10.2. Shortened drill and completion time 


\subsection{Well Construction/Completion}

3.11.1. Economic acid-resistant cements

3.11.2. Adaptation of Dual Tube Reverse Circulation (DTRC) drilling for use on generic rigs.

3.11.3. Wellbore/pump designs/deployment allowing pumps to be set at any depth without increasing casing diameter

3.11.4. Shoe-to-shoe drilling without stopping to plug each lost-circulation zone

3.12. Wellfield O\&M

3.12.1. New corrosion-resistant casing materials/coating systems to reduce well life-cycle cost

\section{TIOs for Energy Conversion}

4.1. Mixed Working Fluid Plants

4.2. Other Innovative Cycles

4.3. Innovative Cycles

4.4. Non-Turbine Cycles

4.5. Alternative Working Fluids (non-hydrocarbons) with Improved Heat Transfer Characteristics

4.6. Advanced Air-Cooled Condensers

4.7. Hybrid Cooling Systems

4.8. Improved Non-condensable Gas Removal Subsystems

4.9. Increased Turbine Efficiency

4.10. Innovative Process Monitors

4.11. Chemistry and Physics of Geothermal Brines

4.12. Innovative Materials

4.13. Cost-effective Plant Design and Construction Strategies

4.14. Automation to Reduce Operating Labor 


\section{Risk Cases Considered}

Seven cases were evaluated for this risk analysis. The Geothermal Expert Team scored the TIOTPM impacts for five separate cases:

1. Hydrothermal Binary 2010

2. Hydrothermal Flash 2010

3. EGS Binary 2010

4. EGS Flash 2010

5. EGS Binary Evolutionary 2040

Two additional cases were developed to evaluate the improvements projected by the GTP research teams in the MYPP:

6. Hydrothermal Binary 2010 MYPP

7. EGS Binary 2010 MYPP

The four GETEM reference cases displayed in Appendices A through D provided the baseline input data profiles for these seven risk cases. The baseline data in the appendix cases are allocated to the risk cases by title: e.g., hydrothermal binary, EGS flash, etc.

\section{Geothermal Expert Team Scoring Matrices}

For each of the 23 TIO Roll-ups that fell within their respective areas of expertise, the experts were asked to estimate minimum, most likely (or expected), and maximum improvements, as well as an estimated probability of success in achieving the "most likely" improvement, to assign to the 13 TPMs. Each range of improvements is expressed in percentage terms, relative to the baseline TPM value, except for the Utilization Factor, Exploration Success, and Confirmation Success TPMs, where the improvements are expressed as absolute additions to the baseline. A minimum improvement value is defined as the lowest possible non-zero value that might result from the R\&D activities, and a maximum is defined as the largest possible advance that could be achieved through R\&D.

The experts were asked to consider a constant budget amount for each of the subgroup program areas, ${ }^{8}$ but told that specific spending on TIO areas could be changed to what they considered optimal levels (e.g., if no projects are currently being funded in a given TIO, they were not precluded from estimating any potential R\&D improvements in that area; and, in fact, were asked to give their estimates on potential improvements if funding for that TIO was realized). This approach to funding eliminated many but not all concerns as to whether a flat-budget funding assumption could, in practice, result in achieving impacts that the experts would assign in a technical assessment of the TIO risks. For some TIOs, experts still recognized a budget constraint in the 2010 time frame that limited the impact of the research on the given TPMs.

\footnotetext{
${ }^{8}$ Consistent with the budget outlined in the 2005 MYPP.
} 
The probability of success is a probability of achieving an advance at the expected value of the estimated range of improvements, regardless of the specific value assigned. This approach enables the expert to define a finite probability that $R \& D$ could generate no technological or economic improvement. In contrast, simply specifying zero as the minimum value in a triangular distribution would give result in very little statistical probability of a zero improvement result being selected in the Monte Carlo simulation. Accordingly, this made it possible to assign lower probabilities of success to higher-risk, more uncertain areas of R\&D. In addition, impact limits reflecting experts' inferences of practical budget constraints were also expressed in terms of lower probabilities of success.

For a given TIO, the R\&D might only yield improvements for one, or a few, of the TPMs. The experts were asked to fill in only the values for improvements where they thought the TIO would have impact. Table 4 identifies graphically those TPMs actually risked by the experts for each TIO. Furthermore, the experts were given a score sheet to record their estimates for the ranges and probabilities of improvements. Tables 5 through 7 show the score sheets that were used by the Expert Team subgroups for some of the TIOs in the EGS Binary 2010 Case (Appendix E provides the full scoring sheets for all of the TIOs in all of the cases).

To assist in assessing risks for the TIOs and interpreting their roll-ups to the TPMs, the Expert Team was provided copies of the GTP Multiyear Program Plan. 
Table 4. Mapping of Which TIOs Impact Each of the GETEM Input TPMs in All Cases.

\begin{tabular}{|c|c|c|c|c|c|c|c|c|c|c|c|c|c|c|c|c|}
\hline \multirow[b]{2}{*}{$\begin{array}{l}\text { TIO } \\
\text { No. }\end{array}$} & \multirow[b]{2}{*}{ TIO Roll-up Name } & \multirow[b]{2}{*}{$\begin{array}{l}\text { Technology } \\
\text { Subgroup }\end{array}$} & \multirow[b]{2}{*}{ TIOs Included } & \multicolumn{12}{|c|}{ GETEM Inputs/ TPMs } & \multirow[b]{2}{*}{ 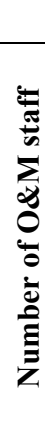 } \\
\hline & & & & 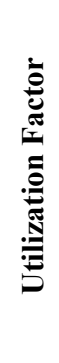 & 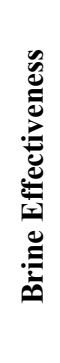 & 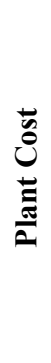 & 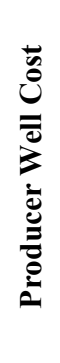 & 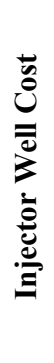 & 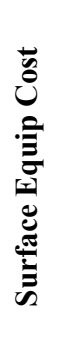 & 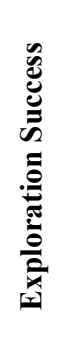 & 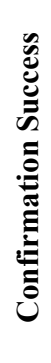 & 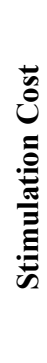 & 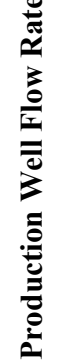 & 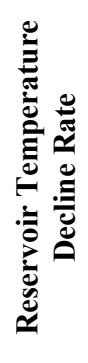 & 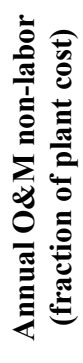 & \\
\hline 1 & Target Temperature Prediction & EGS/ Exploration & 1.1 .1 & & & & & & & & & & & & & \\
\hline 2 & Fractures, Proppants, Rheology & EGS/ Exploration & 1.2 .1 & & & & & & & & & & & & & \\
\hline 3 & Fracture Control/Packers & EGS/ Exploration & 1.2 .2 & & & & & & & & & & & & & \\
\hline 4 & Fracture Prediction Modeling & EGS/ Exploration & 1.2 .3 & & & & & & & & & & & & & \\
\hline 5 & Subsurface Circulation System & EGS/ Exploration & 1.2 .4 & & & & & & & & & & & & & \\
\hline 6 & $\begin{array}{l}\text { Reservoir Performance } \\
\text { Modeling }\end{array}$ & EGS/ Exploration & 1.3 .1 & & & & & & & & & & & & & \\
\hline 7 & Artificial Lift & EGS/ Exploration & 1.3 .2 & & & & & & & & & & & & & \\
\hline 8 & Short-Circuit Mitigation & EGS/ Exploration & 1.3 .3 & & & & & & & & & & & & & \\
\hline 9 & Technical Systems Analysis & EGS/ Exploration & $1.4 .1,1.4 .2,1.5 .1$ & & & & & & & & & & & & & \\
\hline 10 & Remote Sensing & EGS/ Exploration & 2.1 & & & & & & & & & & & & & \\
\hline 11 & Geophysics & EGS/ Exploration & 2.2 & & & & & & & & & & & & & \\
\hline
\end{tabular}




\begin{tabular}{|c|c|c|c|c|c|c|c|c|c|c|c|c|c|c|c|c|}
\hline \multirow[b]{2}{*}{$\begin{array}{l}\text { TIO } \\
\text { No. }\end{array}$} & \multirow[b]{2}{*}{ TIO Roll-up Name } & \multirow[b]{2}{*}{$\begin{array}{l}\text { Technology } \\
\text { Subgroup }\end{array}$} & \multirow[b]{2}{*}{ TIOs Included } & \multicolumn{12}{|c|}{ GETEM Inputs/ TPMs } & \multirow[b]{2}{*}{ 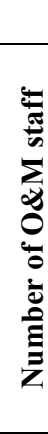 } \\
\hline & & & & 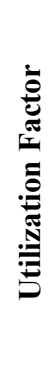 & 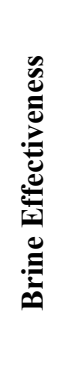 & 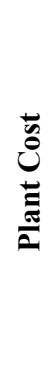 & 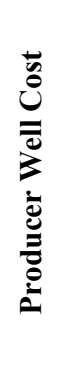 & 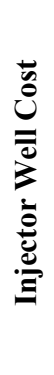 & 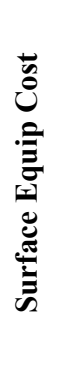 & 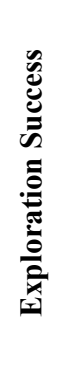 & 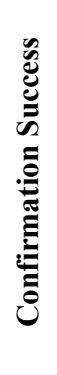 & 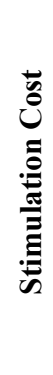 & 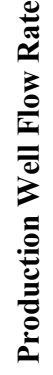 & 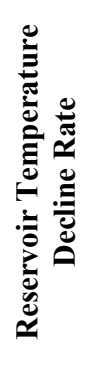 & 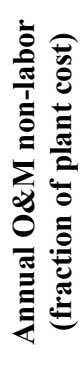 & \\
\hline 12 & Geochemistry & EGS/ Exploration & 2.3 & & & & & & & & & & & & & \\
\hline 13 & Resource Assessment & EGS/ Exploration & 2.4 & & & & & & & & & & & & & \\
\hline 14 & Drilling Time Reduction & Wellfield/ Drilling & $\begin{array}{l}3.9 .1-3.9 .3,3.10 .2 \\
3.11 .2,3.11 .4\end{array}$ & & & & & & & & & & & & & \\
\hline 15 & Wellbore Lining Reduction & Wellfield/ Drilling & $\begin{array}{l}3.8 .1,3.8 .2,3.11 .3 \\
3.12 .1\end{array}$ & & & & & & & & & & & & & \\
\hline 16 & Flat-Time Reduction & Wellfield/ Drilling & 3.10 .1 & & & & & & & & & & & & & \\
\hline 17 & $\begin{array}{l}\text { Instrumentation, Testing, } \\
\text { Simulation }\end{array}$ & Wellfield/ Drilling & $3.1-3.6$ & & & & & & & & & & & & & \\
\hline 18 & Completion and Production & Wellfield/ Drilling & $3.7,3.11 .1$ & & & & & & & & & & & & & \\
\hline 19 & Cycle Related & Power Conversion & $4.1 .1-4.1 .5$ & & & & & & & & & & & & & \\
\hline 20 & Component Related & Power Conversion & $4.1 .6-4.1 .9$ & & & & & & & & & & & & & \\
\hline 21 & Monitoring and Scaling & Power Conversion & 4.10 & & & & & & & & & & & & & \\
\hline 22 & Design/Construction Related & Power Conversion & $4.11-4.13$ & & & & & & & & & & & & & \\
\hline 23 & Automation/Enhanced Controls & Power Conversion & 4.15 & & & & & & & & & & & & & \\
\hline
\end{tabular}

Note: Diagonal lines identify the subset of TPMs risked for each TIO in the MYPP Cases. 
Table 5. EGS/Exploration Subgroup Scoring Matrix- EGS Binary 2010 Case*

\begin{tabular}{|c|c|c|c|c|c|c|c|c|}
\hline \multirow{2}{*}{ TIO Categories } & \multirow{2}{*}{ Metrics/TPMs } & \multirow{2}{*}{ Units } & \multirow{2}{*}{$\begin{array}{l}\text { Baseline } \\
\text { in } 2005\end{array}$} & \multicolumn{3}{|c|}{ Improvement Range } & \multirow{2}{*}{$\begin{array}{l}\text { Prob. of } \\
\text { Success }\end{array}$} & \multirow{2}{*}{$\begin{array}{c}\text { Expert } \\
\text { Comments }\end{array}$} \\
\hline & & & & Min & Expected & Max & & \\
\hline \multirow{5}{*}{$\begin{array}{l}\text { TIO 1- Increase } \\
\text { accuracy of } \\
\text { target } \\
\text { temperature } \\
\text { prediction }\end{array}$} & Exploration Success & Ratio & 0.80 & $1 \%$ & & & $90 \%$ & \\
\hline & Confirmation Success & Ratio & 0.80 & $1 \%$ & $2 \%$ & $4 \%$ & $90 \%$ & \\
\hline & Stimulation Cost & $\$ \mathrm{~K} /$ well & 750 & & & & & \\
\hline & Production WellFlow Rate & gpm/well & 332 & $5 \%$ & $7 \%$ & & & \\
\hline & Temperature Drawdown Rate & $\% /$ year & $3 \%$ & & & & & \\
\hline \multirow{5}{*}{$\begin{array}{l}\text { TIO 2- Improve } \\
\text { fracture } \\
\text { methods, } \\
\text { proppants and } \\
\text { rheology }\end{array}$} & Exploration Success & Ratio & 0.80 & & & & & \\
\hline & Confirmation Success & Ratio & 0.80 & & & & & \\
\hline & Stimulation Cost & \$K/well & 750 & $-35 \%$ & $0 \%$ & $+50 \%$ & $60 \%$ & \\
\hline & Production Well Flow Rate & gpm/well & 332 & $5 \%$ & $13 \%$ & $25 . \%$ & $60 \%$ & \\
\hline & Temperature Drawdown Rate & $\% /$ year & $3 \%$ & & & & & \\
\hline \multirow{5}{*}{$\begin{array}{l}\text { TIO 3- Control } \\
\text { of fracturing - } \\
\text { new and } \\
\text { improved } \\
\text { borehole packers }\end{array}$} & Exploration Success & Ratio & 0.80 & & & & & \\
\hline & Confirmation Success & Ratio & 0.80 & & & & & \\
\hline & Stimulation Cost & $\$ \mathrm{~K} /$ well & 750 & $-25 \%$ & $0 \%$ & $25 \%$ & $10 \%$ & \\
\hline & Production Well Flow Rate & gpm/well & 332 & $10 \%$ & $17.5 \%$ & $35 \%$ & $25 \%$ & \\
\hline & Temperature Drawdown Rate & $\% /$ year & $3 \%$ & & & & & \\
\hline \multirow{2}{*}{$\begin{array}{l}\text { TIO 4- Develop } \\
\text { numerical } \\
\text { models that }\end{array}$} & Exploration Success & Ratio & 0.80 & & & & & \\
\hline & Confirmation Success & Ratio & 0.80 & & & & & \\
\hline \multirow{2}{*}{$\begin{array}{l}\text { accurately } \\
\text { predict fracture } \\
\text { growth and }\end{array}$} & Stimulation Cost & $\$ \mathrm{~K} /$ well & 750 & $-20 \%$ & $10 \%$ & $30 \%$ & $10 \%$ & \\
\hline & Production Well Flow Rate & gpm/well & 332 & $10 \%$ & $25 \%$ & $50 \%$ & $70 \%$ & \\
\hline $\begin{array}{l}\text { permeability } \\
\text { development }\end{array}$ & Temperature Drawdown Rate & $\% /$ year & $3 \%$ & $4 \%$ & $10 \%$ & $15 \%$ & $40 \%$ & \\
\hline
\end{tabular}

*This example shows only four of the 13 TIOs in this subgroup. Negative improvement values indicate a potential degradation in a TPM resulting from improvement in one or more other TPMs. 
Table 6. Wellfield/Drilling Subgroup Scoring Matrix- EGS Binary 2010 Case* $^{*}$

\begin{tabular}{|c|c|c|c|c|c|c|c|c|}
\hline \multirow{2}{*}{ TIO Categories } & \multirow{2}{*}{ Metrics/TPMs } & \multirow{2}{*}{ Units } & \multirow{2}{*}{$\begin{array}{l}\text { Baseline } \\
\text { in } 2005\end{array}$} & \multicolumn{3}{|c|}{ Improvement Range } & \multirow{2}{*}{$\begin{array}{l}\text { Probability } \\
\text { of Success }\end{array}$} & \multirow{2}{*}{$\begin{array}{c}\text { Expert } \\
\text { Comments }\end{array}$} \\
\hline & & & & Min & Expected & Max & & \\
\hline \multirow{4}{*}{$\begin{array}{l}\text { TIO 14- Reduction of } \\
\text { drilling time and } \\
\text { expense, especially in } \\
\text { hard abrasive } \\
\text { formations }\end{array}$} & Well Cost & \$K/well & 4,918 & $5 \%$ & $12 \%$ & $20 \%$ & $65 \%$ & \\
\hline & Surface Equipment Cost & $\$ \mathrm{~K} /$ well & 100 & & & & & \\
\hline & $\begin{array}{l}\text { Production Well Flow } \\
\text { Rate }\end{array}$ & gpm/well & 332 & & & & & \\
\hline & Annual O\&M Non-labor & $\begin{array}{c}\% \text { of } \\
\text { field cost }\end{array}$ & $1.5 \%$ & & & & & \\
\hline \multirow{4}{*}{$\begin{array}{l}\text { TIO 15- Reduction } \\
\text { time and expense to } \\
\text { line the wellbore } \\
\text { (including using less } \\
\text { material and less } \\
\text { costly material) }\end{array}$} & Well Cost & \$K/well & 4,918 & $4 \%$ & $10 \%$ & $15 \%$ & $50 \%$ & \\
\hline & Surface Equipment Cost & \$K/well & 100 & & & & & \\
\hline & $\begin{array}{l}\text { Production Well Flow } \\
\text { Rate }\end{array}$ & gpm/well & 332 & & & & & \\
\hline & Annual O\&M Nonlabor & $\begin{array}{c}\% \text { of } \\
\text { field cost }\end{array}$ & $1.5 \%$ & & & & & \\
\hline \multirow{4}{*}{$\begin{array}{l}\text { TIO 16- Reduction of } \\
\text { non-essential flat time }\end{array}$} & Well Cost & \$K/well & 4,918 & $2 \%$ & $4 \%$ & $10 \%$ & $50 \%$ & \\
\hline & Surface Equipment Cost & $\$ \mathrm{~K} /$ well & 100 & & & & & \\
\hline & $\begin{array}{l}\text { Production Well Flow } \\
\text { Rate }\end{array}$ & gpm/well & 332 & & & & & \\
\hline & Annual O\&M Nonlabor & $\begin{array}{c}\% \text { of } \\
\text { field cost } \\
\end{array}$ & $1.5 \%$ & & & & & \\
\hline \multirow{4}{*}{$\begin{array}{l}\text { TIO 17- Development } \\
\text { of basic information } \\
\text { through analysis and } \\
\text { simulation efforts. }\end{array}$} & Well Cost & \$K/well & 4,918 & $4 \%$ & $8 \%$ & $12 \%$ & $75 \%$ & $\begin{array}{l}\text { Research is more } \\
\text { focused on rock } \\
\text { mechanics than in rock } \\
\text { formation for EGS case. }\end{array}$ \\
\hline & Surface Equipment Cost & $\$ \mathrm{~K} /$ well & 100 & & & & & \\
\hline & $\begin{array}{l}\text { Production Well Flow } \\
\text { Rate }\end{array}$ & gpm/well & 332 & & & & & \\
\hline & Annual O\&M Nonlabor & $\begin{array}{c}\% \text { of field } \\
\text { cost }\end{array}$ & $1.5 \%$ & & & & & \\
\hline
\end{tabular}

*This example shows only four of the five TIOs in this subgroup. 
Table 7. Energy Conversion Subgroup Scoring Matrix- EGS Binary 2010 Case.*

\begin{tabular}{|c|c|c|c|c|c|c|c|c|}
\hline \multirow{2}{*}{$\begin{array}{l}\text { TIO } \\
\text { Categories }\end{array}$} & \multirow[b]{2}{*}{ GETEM INPUTS/TPMS } & \multirow[b]{2}{*}{ Units } & \multirow{2}{*}{$\begin{array}{l}\text { Baseline } \\
\text { in } 2005 \\
\end{array}$} & \multicolumn{3}{|c|}{ Improvement Range } & \multirow{2}{*}{$\begin{array}{c}\text { Probability } \\
\text { of Success }\end{array}$} & \multirow[b]{2}{*}{ Expert Comments } \\
\hline & & & & Min & Expected & Max & & \\
\hline \multirow{5}{*}{$\begin{array}{l}\text { TIO 19- } \\
\text { Cycle Related }\end{array}$} & Utilization Factor & $\%$ & $95 \%$ & $1.0 \%$ & $3.0 \%$ & $4.0 \%$ & $90 \%$ & \\
\hline & Brine Effectiveness & W-h/lb & 10.86 & $10 \%$ & $25 . \%$ & $40 . \%$ & $90 \%$ & $\begin{array}{l}\text { There are opportunities to optimize } \\
\text { plant configuration that would } \\
\text { improve brine effectiveness }\end{array}$ \\
\hline & Plant Cost & $\$ / \mathrm{kW}$ & 2,140 & $-10 \%$ & $10 \%$ & $30 \%$ & $30 \%$ & \\
\hline & Annual O\&M Nonlabor & $\%$ & $1.5 \%$ & & & & & \\
\hline & Number of O\&M Staff & $\#$ & 14.6 & & & & & \\
\hline \multirow{5}{*}{$\begin{array}{l}\text { TIO 20- } \\
\text { Component } \\
\text { Related }\end{array}$} & Utilization Factor & $\%$ & $95 \%$ & $1 \%$ & $3 \%$ & $4 \%$ & $80 \%$ & \\
\hline & Brine Effectiveness & $\mathrm{W}-\mathrm{h} / \mathrm{lb}$ & 10.86 & $3.3 \%$ & $8 . \%$ & $\begin{array}{c}12.5 \\
\%\end{array}$ & $75 \%$ & \\
\hline & Plant Cost & $\$ / \mathrm{kW}$ & 2,140 & $2 \%$ & $5 . \%$ & $8 \%$ & $75 \%$ & \\
\hline & Annual O\&M Nonlabor & $\%$ & $1.5 \%$ & $0 \%$ & $5 \%$ & $8 \%$ & $50 \%$ & \\
\hline & Number of O\&M Staff & \# & 14.6 & & & & & \\
\hline \multirow{5}{*}{$\begin{array}{l}\text { TIO 21- } \\
\text { Monitoring \& } \\
\text { Scaling }\end{array}$} & Utilization Factor & $\%$ & $95 \%$ & $0 . \%$ & $0.3 \%$ & $0.5 \%$ & $30 \%$ & \\
\hline & Brine Effectiveness & $\mathrm{W}-\mathrm{h} / \mathrm{lb}$ & 10.86 & $2.5 \%$ & $6.5 \%$ & $10 \%$ & $55 \%$ & \\
\hline & Plant Cost & $\$ / \mathrm{kW}$ & 2,140 & & & & & \\
\hline & Annual O\&M Nonlabor & $\%$ & $1.5 \%$ & $2.8 \%$ & $17 \%$ & $40 \%$ & $65 \%$ & \\
\hline & Number of O\&M Staff & \# & 14.6 & & & & & \\
\hline \multirow{5}{*}{$\begin{array}{l}\text { TIO 22- } \\
\text { Design// } \\
\text { Construction } \\
\text { Related }\end{array}$} & Utilization Factor & $\%$ & $95 \%$ & $0 \%$ & $2 \%$ & $5 \%$ & $50 \%$ & \\
\hline & Brine Effectiveness & $\mathrm{W}-\mathrm{h} / \mathrm{lb}$ & 10.86 & & & & & \\
\hline & Plant Cost & $\$ / \mathrm{kW}$ & 2,140 & $6 \%$ & $16 \%$ & $25 \%$ & $75 \%$ & \\
\hline & Annual O\&M Nonlabor & $\%$ & $1.5 \%$ & & & & & \\
\hline & Number of O\&M Staff & $\#$ & 14.6 & & & & & \\
\hline
\end{tabular}

*This example shows only four of the five TIOs in this subgroup. Negative improvement values indicate a potential degradation in a TPM resulting from improvement in one or more other TPMs. For example, a negative value in the minimum plant cost improvement entry can accommodate an increase in the plant cost in order to achieve improved brine effectiveness. 
Because TIOs impact the TPMs differently for hydrothermal vs. EGS resources, and for binary vs. flashed-steam conversion technologies, the experts were asked to fill out the seven score sheets separately, but only for those cases and TIOs to which they felt comfortable and qualified to respond. The text box on the next page shows the suggested scoring process given to the Expert Team.

In addition to the four 2010 cases, the experts were asked to consider the EGS Binary case for an "Evolutionary 2040" scenario. The evolutionary scenario sought to project mid- to long-term incremental changes to the current technology. Although stated as 2040, the exact year that the improvements would be achieved was not critical - the experts were asked to estimate potential improvements, assuming available time and budget would be adequate to achieve the research goals.

Furthermore, the experts were asked to consider the relationships between and within the TIOs and how improvements in one area should relate to advancements or the probability of advancements in other areas. For each TPM that is affected by multiple TIOs, the impacts from each of the TIOs were added together and assumed to be equally weighted, unless the Expert Team specified other relationships (e.g., the Wellfield/Drilling subgroup used a multiplicative method of combining the impacts). Additionally, the team subgroups defined limits (or caps) to constrain the amounts of improvement achievable for most of the TPMs. The caps were added when it was recognized that simply summing the impacts of all TIOs affecting any given TPM could, in some instances, overstate the achievable values of technologic or economic improvements. In extreme cases, this might cause GETEM to calculate negative LCOE values.

PERI compiled the individual experts' scoring sheets, and recorded the consensus estimates from the subgroup phone conferences. That information has been documented for archival record of this work. The consensus estimates were then relayed to the entire Geothermal Expert Team for final comments or suggested changes to these values. The final subgroup consensus score sheets were combined into one set of score sheets, which are shown in Appendix E. 


\section{Suggested Scoring Process for the Expert Team}

1. When estimating the range of impact a single TIO Roll-up may have on a GETEM input parameter, assume initially that the effects of all TIO Roll-ups that impact that parameter are additive and equally weighted. Equivalently, assume that the impact any TIO Roll-up may have on a GETEM input parameter is independent and additive with impacts of other TIO Roll-ups.

2. Document the rationale for your estimates in the "comments" column. Include as many references as possible as part of your rationale. This is a requirement imposed by the administration and Congress that is critical to building the Program's credibility.

3. When assessing a TIO Roll-up, refer to the detailed list of TIOs to get an idea of the specific research topics involved. Make your best judgment on the combined impact of these specific TIOs on their respective TIO Roll-up. Refer as needed to the MYPP document for fuller descriptions of the specific research topics.

4. Start with the hydrothermal binary case. Once you have estimated a range of impact for a TIO Roll-up for this case, ask whether that range would change for any of the other cases; and, if so, enter those ranges on the proper scoring sheets.

5. Once assessments have been made for each of the TIO Roll-ups for a case, add the combined improvements for each GETEM input variable (assuming the R\&D is successful), and do a litmus test on the combined impact. If the combined amount appears to be too high or too low, try to identify and note any relationships between the effects of the TIO Roll-ups that might argue against equal weighting and/or the additivity (i.e., consider the relationships between the TIO Roll-ups and how improvements in one area can increase, reduce, or preclude advancements or the probability of advancements in other areas). Adjust the initial ranges based on these considerations.

6. Leave cells blank when the TIO Roll-up does not impact a specific GETEM input (do not bother entering zeros).

7. Only address those TIOs and GETEM input variables that you feel you have the expertise to consider. Leave everything else blank.

\section{MYPP Cases Scoring}

As noted above in identifying the seven risk cases considered in this task, two of them correspond to References Cases in the MYPP document. Paralleling the Expert Team improvement estimates for the other five risk cases, the improvements cited in the MYPP document were translated into comparable estimates of ranges of improvements and probabilities of success for these two risk cases: 1) Hydrothermal Binary MYPP 2010, and 2) EGS Binary MYPP 2010. These MYPP-based cases were included in the analysis to both test the Monte Carlo model formulation as well as to provide a point of reference to the Expert Team cases. MYPP estimates were culled from the MYPP report by Martin Vorum and Gian Porro. Further expert input was provided by Susan Petty, Joel Renner, and Chip Mansure. The following general approach was used: 
1. In most cases, the improvement values identified for 2010 to 2016 were used and assumed to be expected (most likely) values.

2. Because the MYPP document does not generally specify improvement ranges for TPMs, minimum and maximum values for each input were calculated by decreasing and increasing the expected value by $25 \%$. This narrow range centered on the expected value and was adopted as a conservative and neutral approach.

3. TIO improvement ranges for Hydrothermal and EGS reference cases were assumed to be the same for EGS/Exploration and Energy Conversion activities. TIO ranges for Wellfield/Drilling were made distinct and consistent with estimates of well cost improvements upon which the two MYPP cases were based. ${ }^{9}$

4. As the LCOE improvements documented in the MYPP were inferred to have already incorporated to some extent a probability of success, the probability-of-success parameter was generally set to $75 \%$ or above. This parameter was set somewhat lower for Exploration-specific TIOs due to current funding and the inherently higher level of uncertainty that often characterizes exploration activity.

5. Weighting, additivity, and imposition of limits to TPM improvements across TIOs were made consistent with those in the Expert Team cases, as describe above.

As indicated by the diagonal lines in Table 5, the TPMs for the MYPP cases often were applied less frequently than in the Expert Team cases. For Exploration and Drilling TIOs, improvement ranges for two TPMs were specified for each TIO, the same as in the Expert Team cases. Only one EGS-related variable was specified in the MYPP but not risked: the amount of power recoverable from the developed reservoir.

\section{Changes Made to Experts Inputs}

The following describes changes that were made to the consensus estimates that the Expert Team subgroups formulated, along with the rationale for making these changes:

1. Use of "old" well cost data for performing the risk analyses. When the process began, the experts noted that the baseline well costs were much lower than currently experienced in industry. In fact, well costs have increased significantly in recent years. This is due largely to increased demand for the limited stock of equipment used for drilling across the geothermal, oil, and gas businesses; and also to increased demand for commodity materials such as steel and concrete. Therefore, at the suggestion of Chip Mansure and Bill Livesay, GETEM was used to examine higher baseline well $\operatorname{costs}^{10}$ for each of the cases. That resulted in increases in LCOE values, particularly for the cases with deeper wells, as would be expected.

However, a key goal of this task is to examine risk implications, specifically using the MYPP projections. Therefore, it was decided by NREL to hold the well costs at the levels used in the GETEM Reference Cases. The percentage improvements that the Expert Team estimated in the context of "new" costs were applied to the original MYPP baseline.

\footnotetext{
${ }^{9}$ As provided by Chip Mansure.

${ }^{10}$ MYPP baseline costs were increased to reflect the change in the Bureau of Labor Statistics Producer Price Index for the product "drilling oil, gas, dry, or service wells."
} 
There are arguments to be made that a persistent, past surplus of drilling capacity has abated to a degree that will support sustained, sellers'-market cost increases. While current expert opinion varies, that view remains to be substantiated and requires long-term data. The MYPP baseline costs are required for continuity in this task, regardless of whether a higher cost basis is eventually shown to be more reflective of the long-term market. Given more time and budget, this issue should be explored further.

2. Cost or performance parameters that are being reduced. Some of the subgroups gave improvements as values greater than $100 \%$ for parameters for which the improvements are defined in GETEM as reductions (e.g., Stimulation Cost, Temperature Drawdown Rate). That would result in negative input values that would cause errors. The experts expressed these as percentages, which have been assumed to be meant as "factors" of improvement. The values greater than $100 \%$ were converted in the following manner: a $200 \%$ improvement was converted to a 50\% reduction, a $300 \%$ improvement converted to a $66 \%$ improvement, and a $400 \%$ improvement converted to a $75 \%$ improvement. ${ }^{11}$ However, it should be noted that improvements that increased a TPM (i.e., Production Well Flow Rate) were not altered in this manner and were allowed to increase, sometimes well above $100 \%$.

3. The plant cost input to GETEM. Initially, the actual "Plant Cost" input variable in GETEM was one of the parameters used as a TPM in the risk computations. However, it was observed that the GETEM model uses other TPMs to affect the total plant cost, such as increasing the size of the plant and increasing the brine effectiveness. This was inconsistent with the way in which the experts were asked to consider the various TIOs. Therefore, the risk method now varies the GETEM cell that applies a standalone "improvement" to the calculated plant cost in the "improved case" results. The same ranges for improvement were used, so this change is assumed minor. However, it should be noted that if the Expert Team specified, for example, a $25 \%$ improvement in plant costs from program $R \& D$, the total reduction of plant costs that GETEM calculates will be more than $25 \%$ when there are also changes to plant size and brine effectiveness.

\footnotetext{
${ }^{11}$ Subsequent to the completion of the risk analysis runs, a more precise conversion method was determined: Fractional improvement $=1-[1 /(1+$ original improvement factor $)]$. This approach yields slightly lower percentages than actually used.
} 


\section{Summary of Results}

Table 8 provides a summary of the results of the risk analysis runs. This table lists the baseline LCOE, the improved LCOE range calculated by GETEM (i.e., the minimum, mean, and maximum LCOEs determined by the risk analysis model), and the probability of meeting the $5 \notin / \mathrm{kWh}$ Program goal.

Table 8. Summary of LCOE Range and Probability of Meeting $5 \phi / \mathrm{kWh}$ Goal by Case

\begin{tabular}{|c|c|c|c|c|c|c|}
\hline \multirow{2}{*}{ Case and Year } & \multirow{2}{*}{$\begin{array}{c}\text { Baseline } \\
2005 \\
\text { LCOE }\end{array}$} & \multicolumn{3}{|c|}{$\begin{array}{l}\text { Improved-Case } \\
\text { LCOE Range }^{12}\end{array}$} & \multicolumn{2}{|c|}{ Probability of Meeting } \\
\hline & & Min & Mean & Max & $\begin{array}{c}5 \phi / \mathrm{kWh} \\
\text { Goal }\end{array}$ & $\begin{array}{c}\text { Mean LCOE } \\
\text { by Case Year }\end{array}$ \\
\hline \multicolumn{7}{|c|}{ Results of Expert Team Estimates } \\
\hline HT Binary 2010 & 8.54 & 3.80 & 4.73 & 6.13 & $75 \%$ & $54 \%$ \\
\hline HT Flash 2010 & 4.73 & 2.94 & 3.43 & 4.13 & $100 \%$ & $54 \%$ \\
\hline EGS Binary 2010 & 28.5 & 5.71 & 11.5 & 18.9 & $\mathrm{~N} / \mathrm{A}^{13}$ & $51 \%$ \\
\hline EGS Flash 2010 & 29.3 & 8.39 & 15.6 & 23.0 & $\mathrm{~N} / \mathrm{A}$ & $53 \%$ \\
\hline Evolutionary EGS Binary 2040 & 28.5 & 3.85 & 6.29 & 13.8 & $14 \%$ & $59 \%$ \\
\hline \multicolumn{7}{|c|}{ Results of MYPP Estimates } \\
\hline HT Binary 2010 & 8.54 & 4.35 & 4.74 & 5.10 & $99 \%$ & $52 \%$ \\
\hline EGS Binary 2010 & 28.5 & 12.5 & 14.3 & 17.8 & $\mathrm{~N} / \mathrm{A}$ & $52 \%$ \\
\hline
\end{tabular}

As can be seen in Table 8, the Hydrothermal (HT) cases, for both the Binary and Flash technologies, have very high probabilities of meeting the $5 \notin / \mathrm{kWh}$ goal by 2010 , while the Enhanced Geothermal Systems (EGS) cases have practically no chance of meeting the $5 \phi / \mathrm{kWh}$ goal by 2010. These results are not surprising, as the use of EGS resources is more of a longterm scenario, as evidenced by their very high Baseline 2005 LCOEs. Still, the EGS cases show significant reductions in LCOE by 2010 (about $50 \%$ or more), and have the potential to make the technology cost competitive by 2040.

It should be noted that for all Binary technology cases, the number of independent power units was assumed to be three units in the baseline and improved to one unit by 2010 or 2040 . This change was specified by NREL staff and leads, by itself, to a reduction in the LCOE of about $1 \varnothing / \mathrm{kWh}$ in all improved Binary LCOEs, regardless of any impacts from the success of the TIOs.

\footnotetext{
${ }^{12}$ The LCOE mean values in Table 8 are calculated as probability-weighted averages.

${ }^{13}$ Three EGS entries in Table 2 are labeled "N/A" (not applicable). This is because Program goals project that technology improvements under DOE research will make it possible for new, greenfield power development projects to attain LCOE values of $5 \mathrm{k} / \mathrm{kWh}$. This goal is further scheduled to occur by 2010 for hydrothermal resource power systems, and by 2040 for EGS power systems. Therefore, the EGS cases would not meet the $5 \notin / \mathrm{kWh}$ threshold by 2010 .
} 
However, in the Flash technology cases, the number of independent power units is one unit in both the baseline and improved cases; and, therefore, has no impact on the Flash LCOEs.

The ranges in Table 8 represent key values from a cumulative probability distribution, and an example of such a cumulative probability distribution function (PDF) for the Hydrothermal Binary 2010 Experts Case is shown in Figure 1. Appendix F provides these cumulative PDFs for each of the seven risk cases of this task.

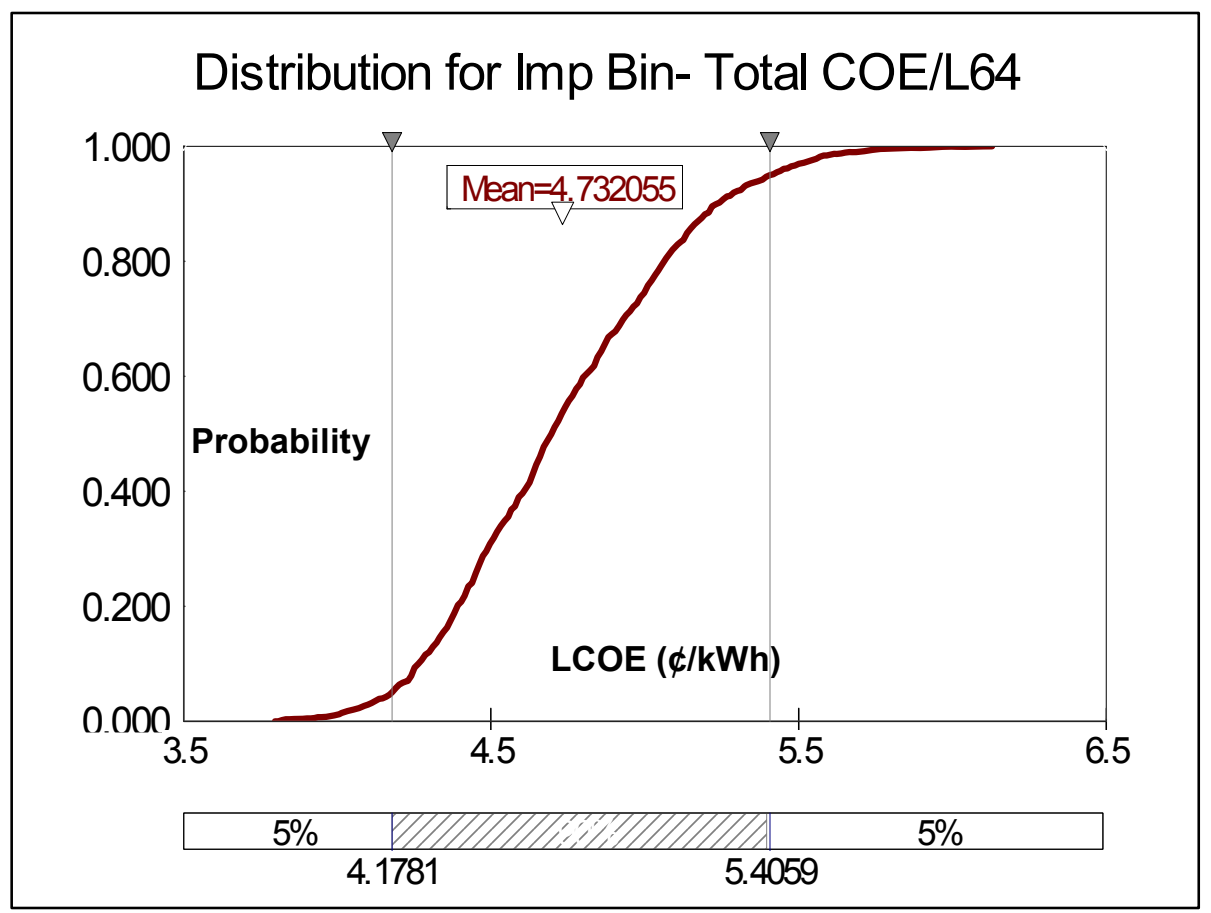

Figure 1. Cumulative PDF for Total LCOE $(\phi / \mathrm{kWh})$ for the Hydrothermal Binary 2010 Experts Case.

Figure 1 shows the range of LCOE for the Hydrothermal Binary 2010 Experts Case (i.e., a minimum of $3.80 \notin / \mathrm{kWh}$, a mean of $4.73 \phi / \mathrm{kWh}$, and a maximum of $6.13 \notin / \mathrm{kWh})$, as well as showing the cumulative probability of achieving any value within that range. For example, to determine what LCOE had at least an $80 \%$ chance of being achieved, one would move horizontally from the 0.800 value on the y-axis until intersecting the curve, and then find the corresponding value on the x-axis (i.e., 5.06 $\phi \mathrm{kWh}$ ). Furthermore, the Cumulative PDF graphs show the $5 \%$ and $95 \%$ values (i.e., $4.18 \phi / \mathrm{kWh}$ and $5.41 \phi / \mathrm{kWh}$, respectively), which are commonly used figures in statistical analysis but do not have any special significance in this study. The LCOE values at the 5\% and 95\% probabilities of occurrence are those values listed in Table 8 as minimum and maximum improved-case LCOEs. 


\section{Case-Specific Results}

The results summarized in Table 8 include the impacts of all of the TIOs combined. However, to assess the individual impacts of each of the 23 roll-up TIOs on a composite LCOE, the risk models were run independently for each roll-up TIO (i.e., zeroing out the impacts of all other TIOs to assess potential "standalone" improvements for each TIO).

The following sections show vertical bar graphs for each case, itemizing the composite LCOE and selected LCOE component groups that GETEM gives as subtotals for the Baseline and Improved runs. Additionally, horizontal bar graphs for each case break out the integrated and standalone impacts of the 23 roll-up TIOs on the LCOE reduction. In these graphs, the heavy, main bars show the mean LCOE reductions, while the lighter error bars extending from the main bars show the maximum LCOE reductions, as determined by the probabilistic risk model.

As stated earlier, the bars for each of the standalone TIOs reflect potential improvements under aggressive budget assumptions (i.e., optimal funding considered independently for each TIO within a fixed budget amount for each subprogram research area). As described on Page 26, the risk team selectively limited the model's freedom to aggregate TIO contributions to each TPM to prevent the TIOs from being fully additive at all probabilities of occurrence. The need for the limitation reflects abstractions in the assessment process of quantifying the TIOs' influences on the TPMs. This limitation ensured that combined TPM impacts in the integrative risk computation were not simply composites of standalone TIO contributions. Absent these constraints, TPM improvements would have been overestimated, resulting in erroneous calculated LCOE values.

Using Figure 7 as an example, the composite mean LCOE improvement for all TIOs (top bar) is about $17 \phi / \mathrm{kWh}$, while the TIOs all have predicted individual mean gains of $1 \varnothing$ to $5 \phi$. Applying all of the individual gains cumulatively would give LCOE improvements greater than $17 \varnothing$. These graphs are useful for helping to understand the potential technical and economic improvements of each TIO, and in judging the relative impacts of TIOs as a basis for allocating research funding. The point made here is that these should not be used to calculate potential improvements across the standalone TIO runs for projecting combined benefits, absent indications that such summing is at least approximately close to an integrated risk result.

A useful next step in this process of developing risk analysis methodology and tools would be to elicit experts' estimates of potential improvements that could be achieved under a truly fixed budget scenario. This would entail assessing potential tradeoffs in achievement as functions of variable task funding, and competition or synergy between achievements among tasks at fixed total funding. This moves in the direction of analyzing management risk. It would entail assessing a program work breakdown structure (WBS) by detailed tasks, making allocations to each task for level of effort, budget, schedule, and product (results) per unit of effort. 


\section{Hydrothermal Binary 2010 Experts Case}

Figure 2 shows the components of the LCOE in the Hydrothermal Binary 2010 Experts Case. The Plant Capital portion of the LCOE is the largest component in the Baseline Case and remains so in the Improved Case, despite incurring the largest absolute LCOE reduction.

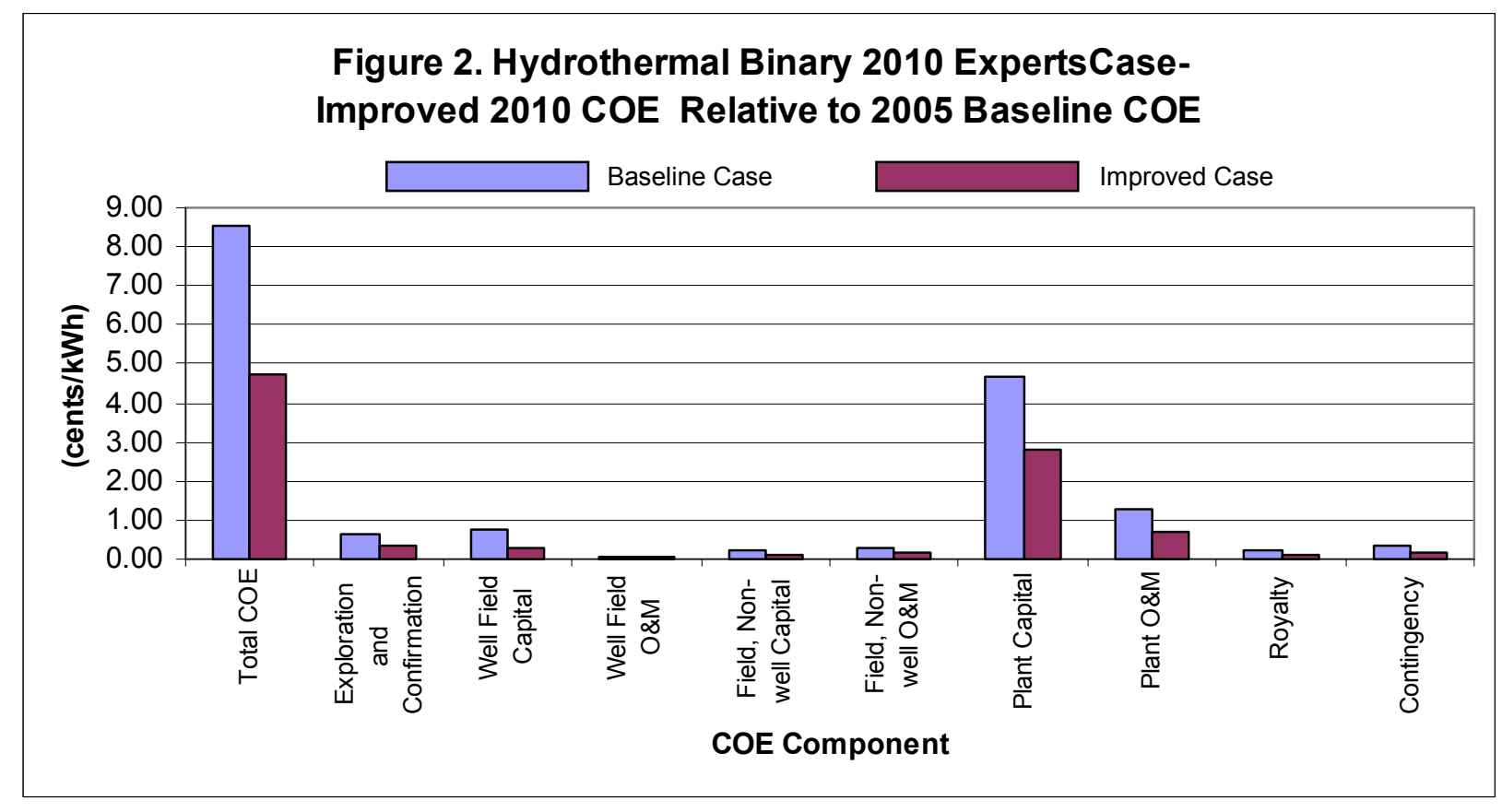

Figure 3 shows the standalone impacts of each individual TIO on the overall LCOE improvement. Again, the power plant unit reduction (from three units in the baseline to one unit in the improved cases) results in a LCOE reduction, which is shown in the figures, of about $1 \phi / \mathrm{kWh}$ in all Binary Cases. As can be seen in Figure 3, and in agreement with the results shown in Figure 2, the largest TIO impacts for this case occur in the Energy Conversion TIOs (TIOs 19, 20, and 22), which impact the Utilization Factor, Brine Effectiveness, and Plant Cost TPMs. The reader may judge the approximate extent to which the standalone TIO impacts are additive, based on whether and by how much their sum exceeds the composite impact on LCOE of all TIOs taken together. 


\section{Figure 3. Hydrothermal Binary 2010 Experts- TIO Improvements to COE Range}

ALL TIOs + Pow er Plant Unit Reduction

Pow er Plant Unit Reduction

T10 1 - Target Temperature Prediction TIO 2 - Fractures, Proppants, Rheology

TIO 3 - Fracture Control/Packers

TTO 4 - Fracture Prediction Modeling

T10 5 - Subsurface Circulation System

TIO 6 - Reservoir Performance Modeling

TIO 8 - Short Circuit Mitigation

TIO 9 - Technical Systems Analysis

TIO 10 - Remote Sensing

T10 11 - Geophysics

TIO 12 - Geochemistry

TIO 13 - Resource Assessment

TIO 14 - Drilling Time Reduction

T10 15 - Wellbore Lining Reduction

TIO 16 - Flat Time Reduction

IO 17 - Instrumentation, Testing

T10 18 - Completion \& Production

TIO 19 - Cycle Related

TIO 20 - Component Related

T10 21 - Monitoring \& Scaling

TIO 22 - Design/Construction Related

TIO 23 - Automation/Enhanced Controls

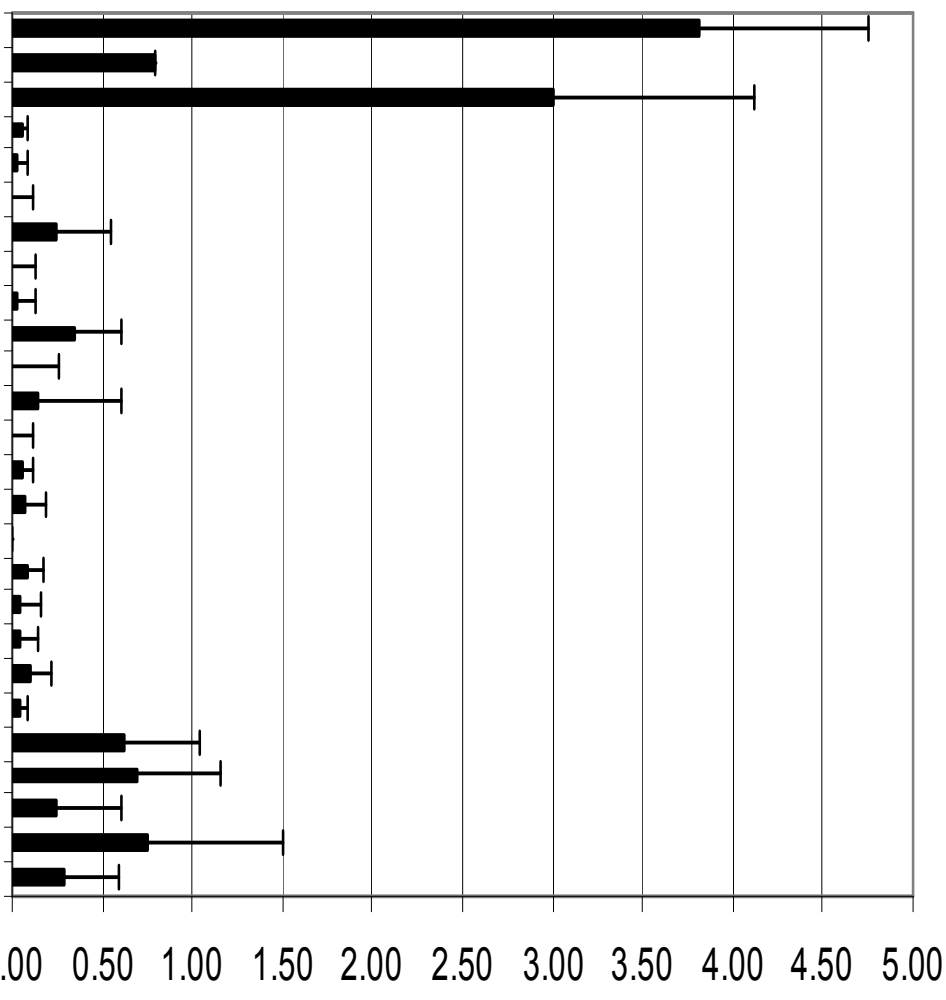

COE Improvement ( $\phi / k W h)$

Bar $=$ Mean, Error Bar $=$ Max 


\section{Hydrothermal Flash 2010 Experts Case}

Figure 4 shows that, for the Flash technology, while the Plant Capital component remains the largest portion of LCOE, it is much smaller than for the Binary technology of the preceding case, as shown in Figure 2. This is consistent with the simpler design of flashed-steam plant power systems. Also, the Well Field Capital portion of the LCOE, while remaining under $1 \phi / \mathrm{kWh}$, becomes a much higher percentage of the total COE than for the Binary technology, reflecting an increase in well depths from 5,000 to 8,000 feet.

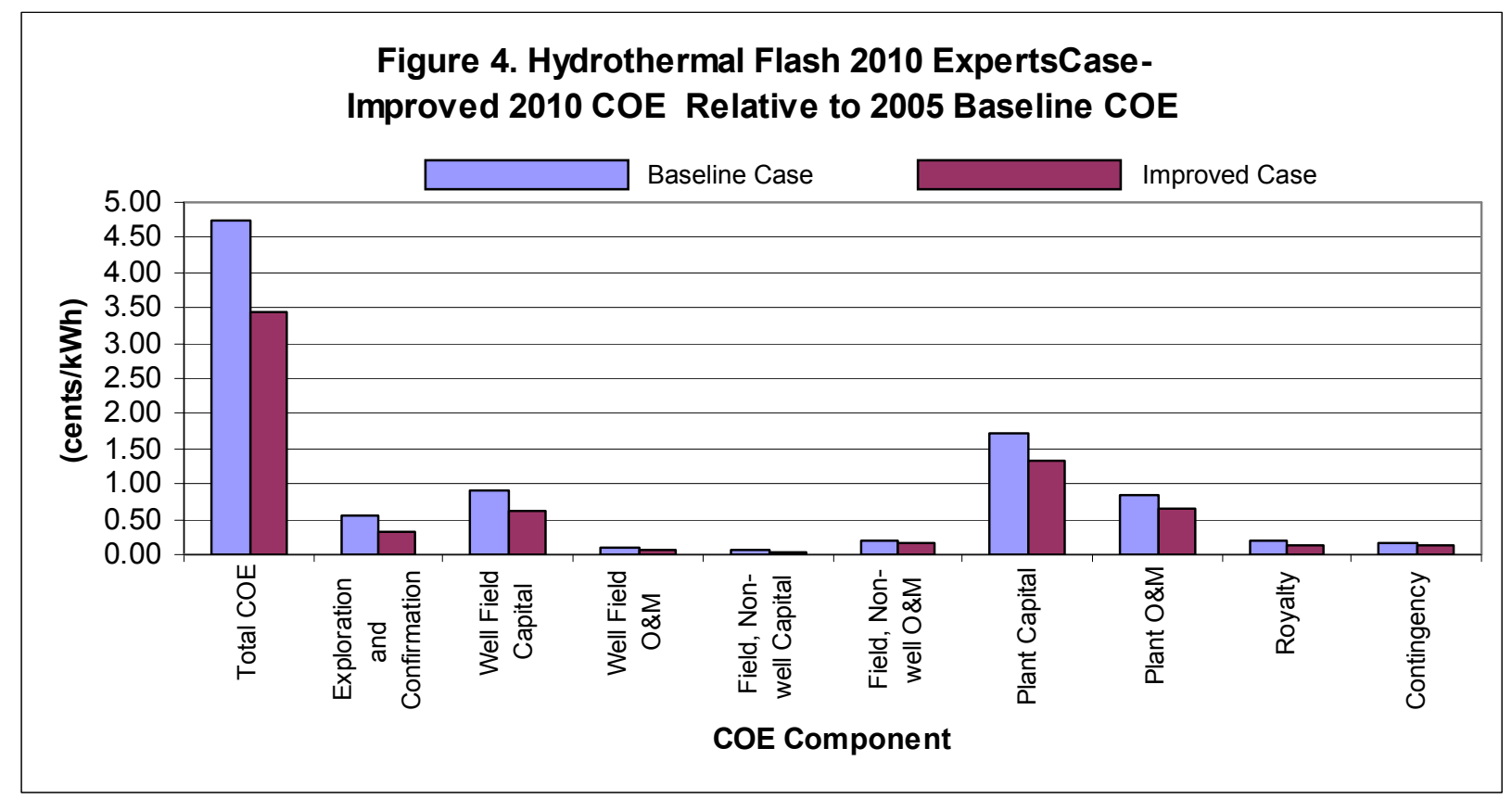

Figure 5 shows the standalone impacts of each TIO on the overall LCOE improvement. In this case, the EGS and Exploration TIOs have almost no impact, while the Energy Conversion TIOs again have the greatest potential impacts. Improvements from the standalone TIOs become more distinguishable and important in the other cases, as seen in the following case descriptions. 


\section{Figure 5. Hydrothermal Flash 2010 Experts- TIO Improvements to COE Range}

TIO 1 - Target Temperature PLediction TOO 2 - Fractures, Proppants, Rheology TIO 3 - Fracture Control/Packers TIO 4 - Fracture Prediction Modeling : TIO 5 - Subsurface Circulation System H TIO 6 - Reservoir Performance Modeling TIO 7 - Artificial Lift TIO 8 - Short Circuit Mitigation TIO 9 - Technical Systems Analysis TIO 10 - Remote Sensing TIO 11 - Geophysics T10 12 - Geochemistry TIO 13 - Resource Assessment TIO 14 - Drilling Time Reduction TIO 15 - Wellbore Lining Reduction TIO 16 - Flat Time Reduction TIO 17 - Instrumentation, Testing, TI0 18 - Completion \& Production TIO 19 - Cycle Related T10 20 - Component Related TIO 21 - Monitoring \& Scaling TIO 22 - Design/Construction Related TIO 23 - Automation/Enhanced Controls

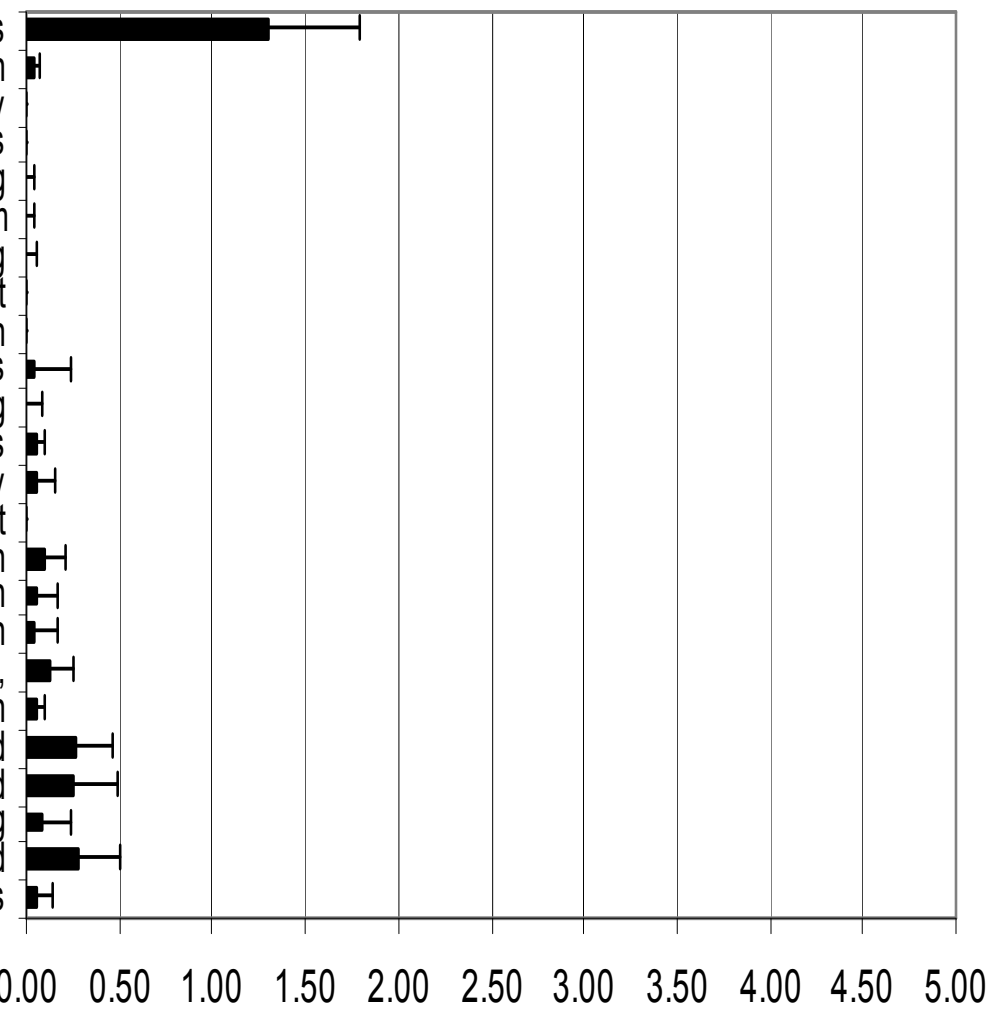

COE Improvement ( $\phi / k W h)$

Bar $=$ Mean, Error Bar $=$ Max 


\section{EGS Binary 2010 Experts Case}

Figure 6 shows that, for the EGS Binary 2010 Case, the Well Field Capital and Field, Non-well O\&M components of LCOE become much larger portions of the total LCOE than in the Hydrothermal cases. Because EGS resources are assumed to be much deeper (i.e., 13,000 to 19,000 feet for EGS compared to 5,000 to 8,000 feet for Hydrothermal), the drilling costs and field O\&M costs are much higher. The dominance of wellfield costs also reflects the role of reservoir stimulation and faster reservoir decline for EGS systems than for the hydrothermal systems in the preceding two cases. Potential improvements in this case are greatest in the Well Field Capital and Field, Non-well O\&M components of LCOE, which results in the Plant Capital component becoming one of the larger portions of the LCOE in the improved case.

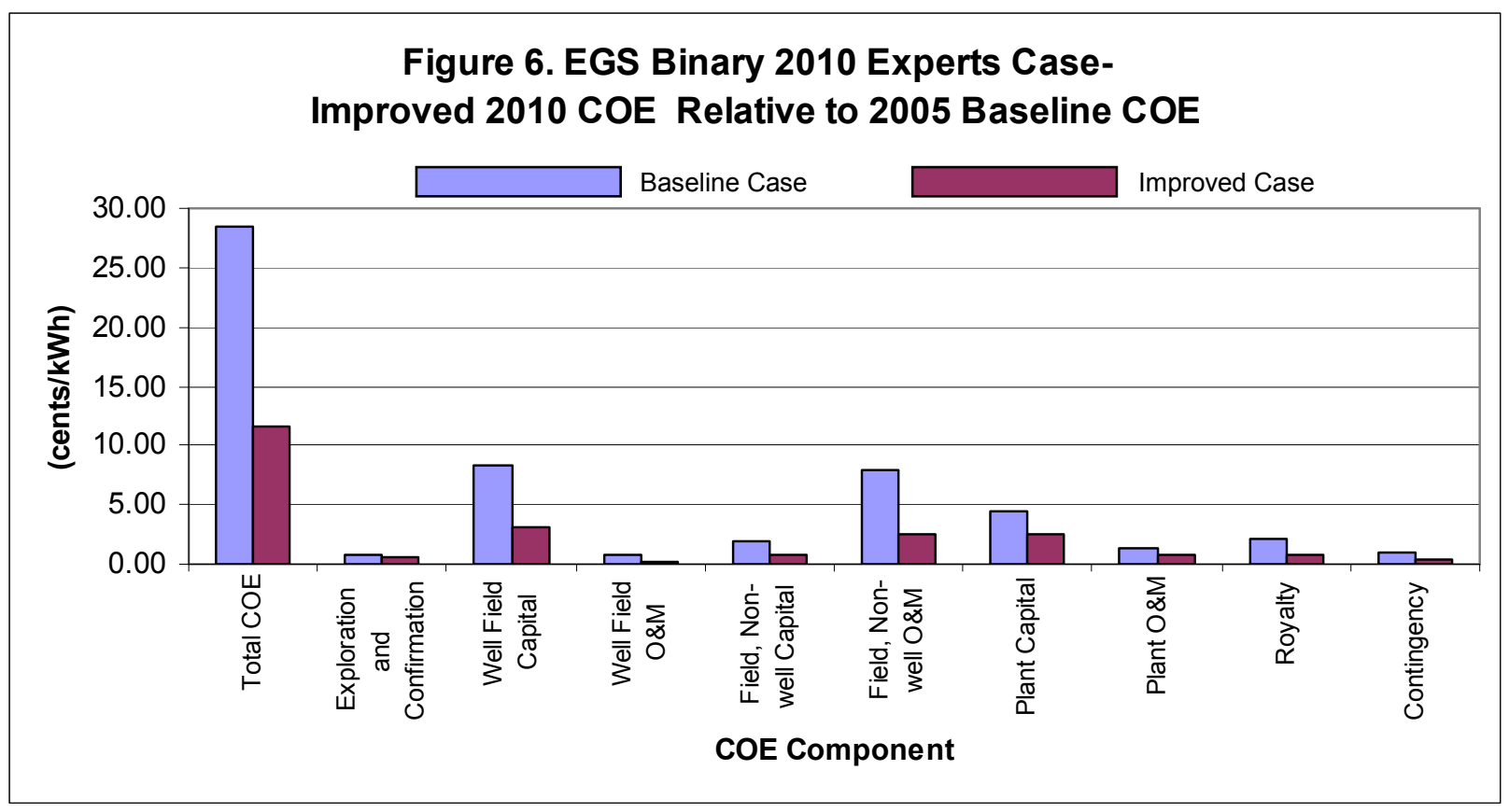

Figure 7 shows that the EGS and Exploration TIOs (TIO 1 through 13) have much greater potential impacts in the EGS case than in the hydrothermal cases. Likewise, the error bars (i.e., indicating the maximum potential improvements) are much larger for these TIOs compared to drilling and conversion TIOs. This implies that, while the probability of success for these TIOs was deemed to be low in the 2010 time frame, they hold the greatest long-term potential impacts for this case. ${ }^{14}$ While the EGS and Exploration TIOs tend to dominate potential impact, cyclerelated improvement in Energy Conversion, TIO 19, actually shows the largest expected impact by 2010 (more than 20\% improvement in LCOE). This impact results from a significantly increased range of improvement and probability of success over the Hydrothermal Binary case reflecting the experts' view that plant configuration can be optimized for the higher temperatures encountered at increased depths in this case.

\footnotetext{
${ }^{14}$ Experts estimating improvement ranges for this discipline generally felt that the current funding level for EGS and Exploration activity, even if reallocated in entirety to each TIO, imposes a limit on the improvement that could be achieved by 2010 . This limit, construed primarily as a reduction in the probability of success, is reflected in the large extent of the positive error bar associated with these TIOs.
} 


\section{Figure 7. EGS Binary 2010 Experts- TIO Improvements to COE Range}

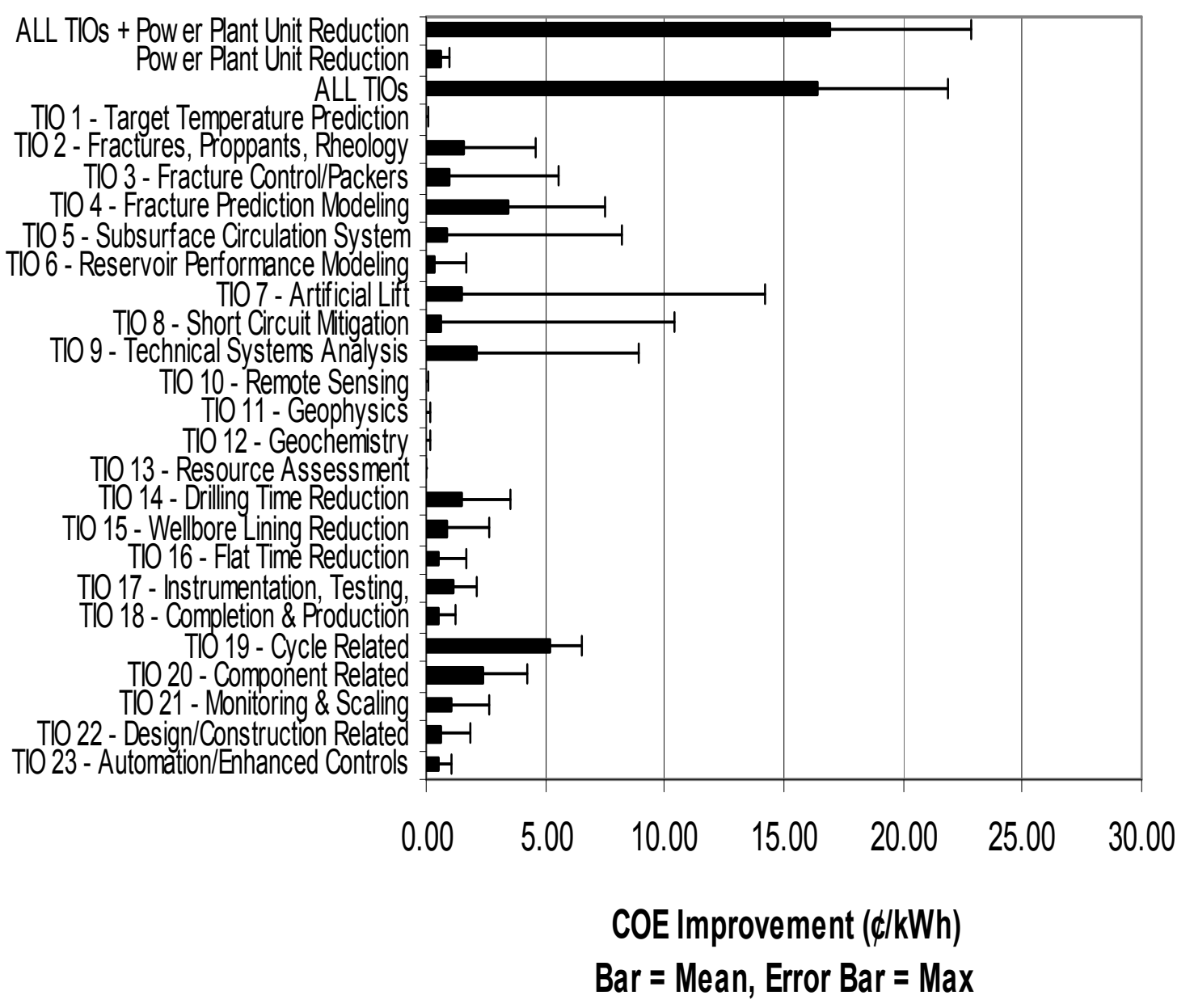




\section{EGS Flash 2010 Experts Case}

Figure 8 shows that, for the EGS Flash 2010 Case, similar to the EGS Binary case, the Well Field Capital and Field, Non-well O\&M components are the predominant components of the baseline LCOE, accounting for $14.1 \phi / \mathrm{kWh}$ and $5.3 \phi / \mathrm{kWh}$, respectively, of the total $29.3 \notin / \mathrm{kWh}$. Again, the main improvements come from lowering these components, both of which are more than cut in half, to $7.0 \phi / \mathrm{kWh}$ and $2.6 \notin / \mathrm{kWh}$, respectively.

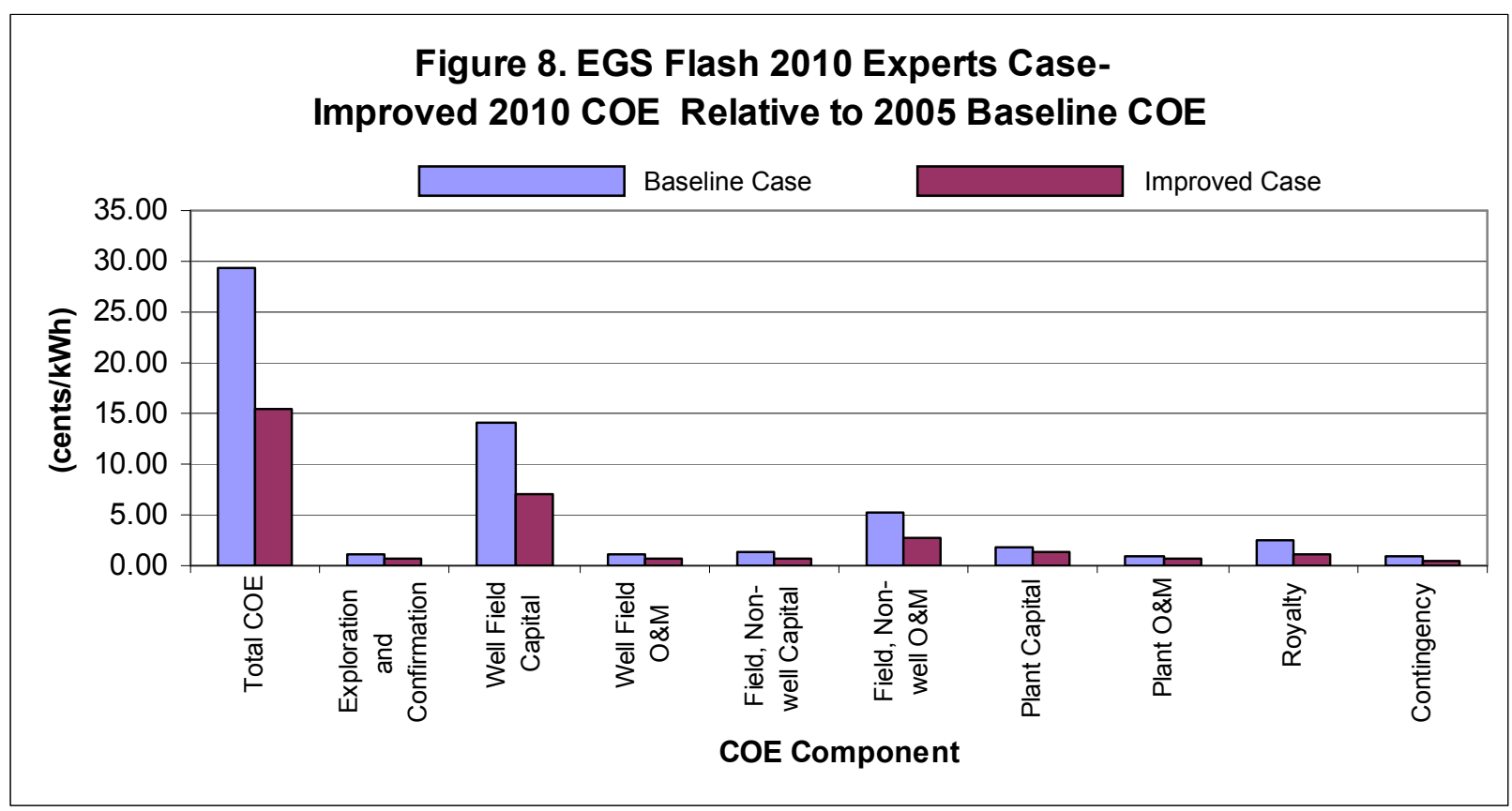

Figure 9 shows that, while the Wellfield and Drilling TIOs (TIO 14 through 18) and the Energy Conversion TIOs (TIOs 19 through 23) generally have larger expected impacts in the 2010 time frame, the greatest potential lies in the EGS and Exploration TIOs. That is, there is large potential in some TIOs that cannot or may not be realized in the limitation of the 2010 time frame. For example, TIO 7, Artificial Lift, has a relatively low probability of success, resulting in a low mean improvement; but its maximum potential improvement (i.e., if this R\&D is successful) is the largest of any TIO for this case.

The estimated mean impacts of each individual TIO are more truly additive in this case, because the improvements are not hitting the caps specified in the model (i.e., the sum of all the individual TIO bars is close to the size of the All TIOs bar). 


\section{Figure 9. EGS Flash 2010 Experts- TIO Improvements to COE Range}

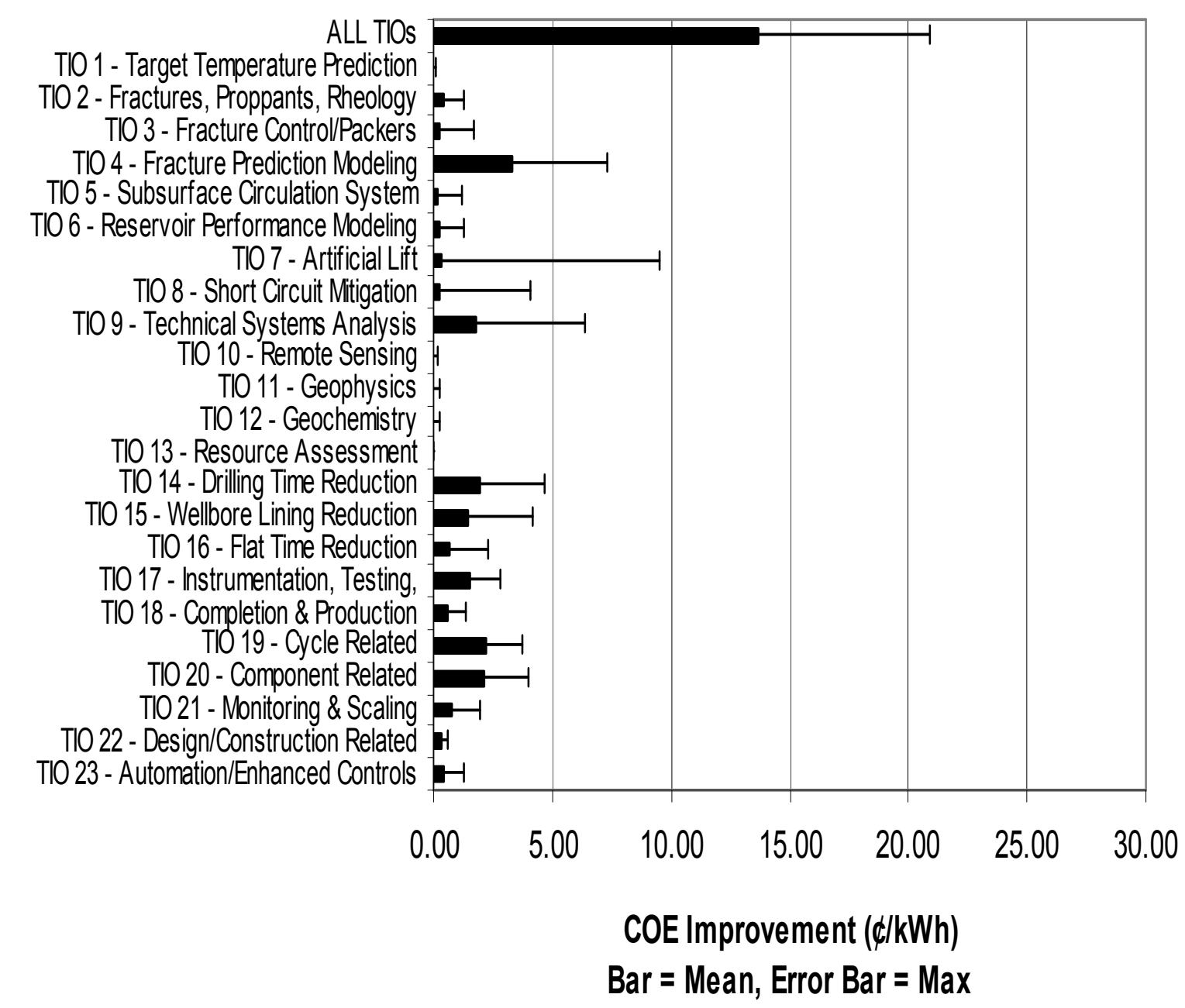




\section{EGS Binary 2040 Evolutionary Experts Case}

Figure 10 shows that the long-term EGS Binary 2040 Evolutionary Case is similar to the shortterm EGS Binary 2010 Case, except that the reductions of the Well Field Capital and Field, Nonwell O\&M components of LCOE are even larger in this 2040 case (i.e., reductions from $8.27 \phi / \mathrm{kWh}$ to $1.21 \phi / \mathrm{kWh}$ in 2040 vs. $3.14 \phi / \mathrm{kWh}$ in 2010 for the Well Field Capital component, and from $7.99 \notin / \mathrm{kWh}$ to $0.59 \notin / \mathrm{kWh}$ in $2040 \mathrm{vs.} 2.45 \notin / \mathrm{kWh}$ in 2010 for the Field, Non-well O\&M component). This is to be expected for long-term GTP R\&D work. Reductions to the Plant Capital component remain relatively constant, which leads to this portion becoming the largest component of the LCOE in the improved 2040 case.

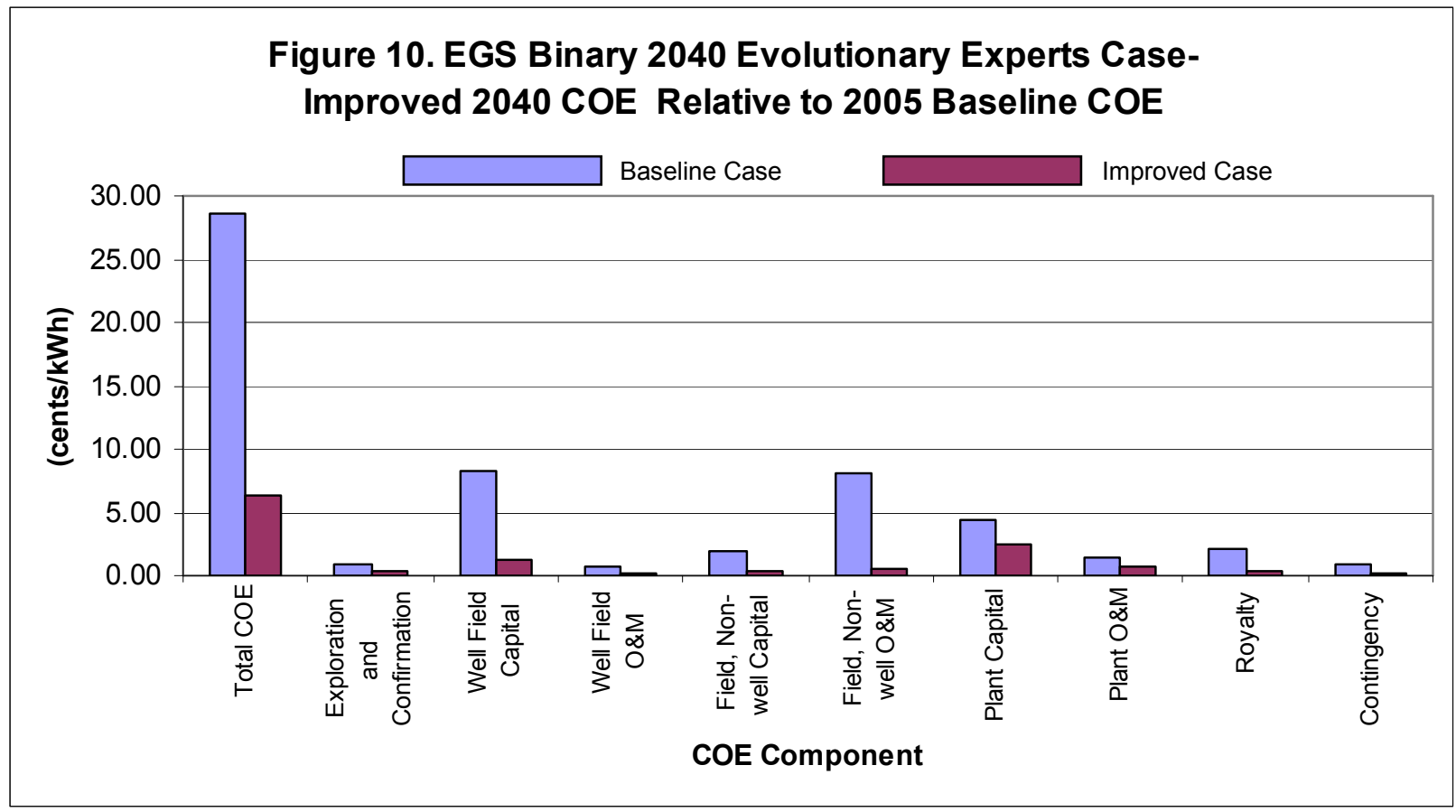

Figure 11 again shows that, for the EGS cases, the maximum potential improvements are from the EGS and Exploration TIOs (TIOs 1 through 13), with the exception of TIO 19. However, in the 2040 time frame, even greater mean improvements are expected. In most cases, this increased improvement results from the experts' perception that more time and money is needed to complete these activities than the 2010 time frame can realistically provide, and this is reflected primarily as an increase in the probability of success for the 2040 cases. 


\section{Figure 11. EGS Binary 2040 Evolutionary Experts-TIO Improvements to COE Range}

ALL TIOs + Pow er Plant Unit Reduction Pow er Plant Unit Reduction

TIO 1 - Target Temperature Prediction

TIO 2 - Fractures, Proppants, Rheology

TIO 3 - Fracture Control/Packers

T10 4 - Fracture Prediction Modeling T10 5 - Subsurface Circulation System T10 6 - Reservoir Performance Modeling TIO 7 - Artificial Lift TIO 9 - Technical Systems Analysis TIO 10 - Remote Sensing TIO 11 - Geophysics T10 12 - Geochemistry TIO 13 - Resource Assessment TIO 14 - Drilling Time Reduction TIO 15 - Wellbore Lining Reduction TIO 16 - Flat Time Reduction T1017 - Instrumentation, Testing, TIO 18 - Completion \& Production TIO 19 - Cycle Related T10 20 - Component Related T10 21 - Monitoring \& Scaling TIO 22 - Design/Construction Related TIO 23 - Automation/Enhanced Controls

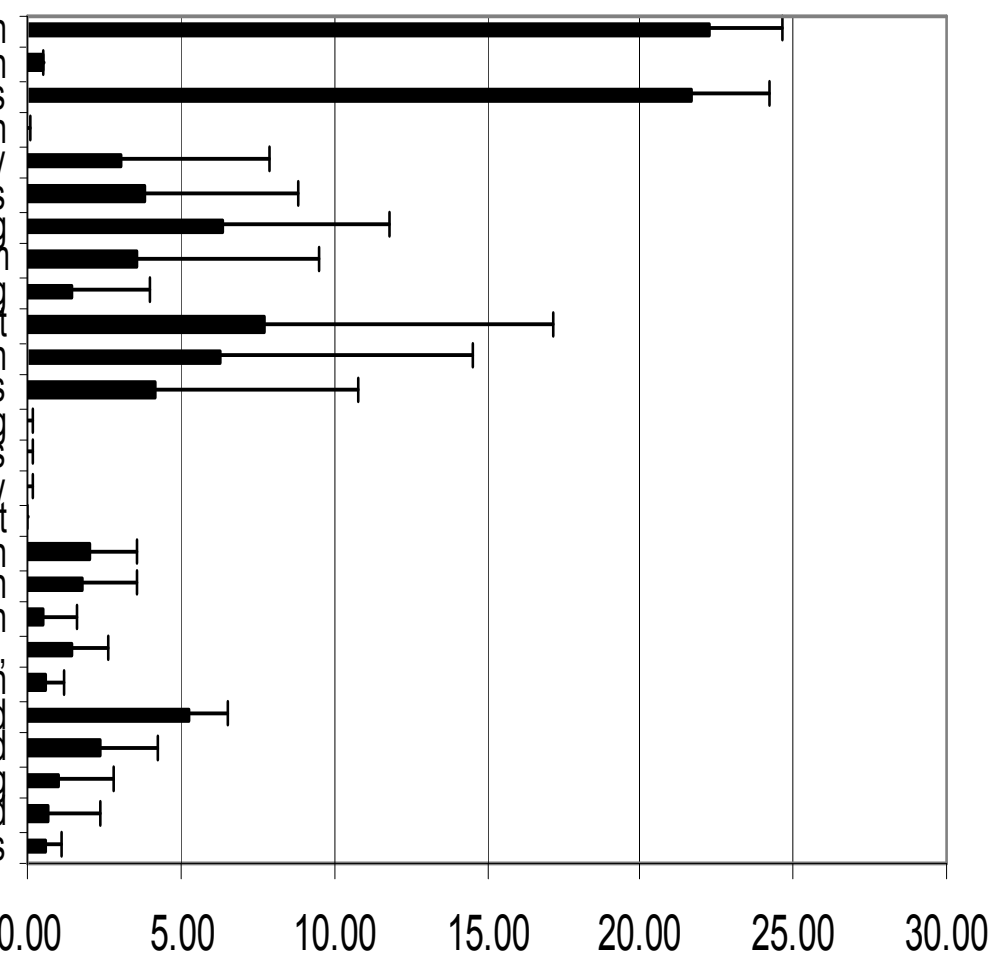

COE Improvement ( $\mathrm{d} / \mathrm{kWh})$ Bar $=$ Mean, Error Bar $=$ Max 


\section{Hydrothermal Binary 2010 MYPP Case}

Figure 12 shows that the Hydrothermal Binary 2010 MYPP Case is very similar to the Hydrothermal Binary 2010 Experts Case. While the mean LCOE reduction is nearly identical in both cases (i.e., reducing from a baseline of $8.54 \phi / \mathrm{kWh}$ to $4.74 \phi / \mathrm{kWh}$ in the MYPP Case vs. $4.73 \phi / \mathrm{kWh}$ in the Experts Case), as shown in Figures F1 and F6 in Appendix F, the range around the mean is much narrower in the MYPP Case (i.e., a minimum and maximum of $4.35 \mathrm{c} / \mathrm{kWh}$ and $5.10 \phi / \mathrm{kWh}$ in the MYPP Case, vs. $3.80 \phi / \mathrm{kWh}$ and $6.13 \phi / \mathrm{kWh}$ in the Experts Case). Although this might imply that the Expert Team thought there was greater uncertainty in the LCOE improvements and in meeting the $5 \mathrm{~d} / \mathrm{kWh}$ goal, it more likely results from the assumptions on which the MYPP cases were based - a set improvement range of $+/-25 \%$ around the expected value.

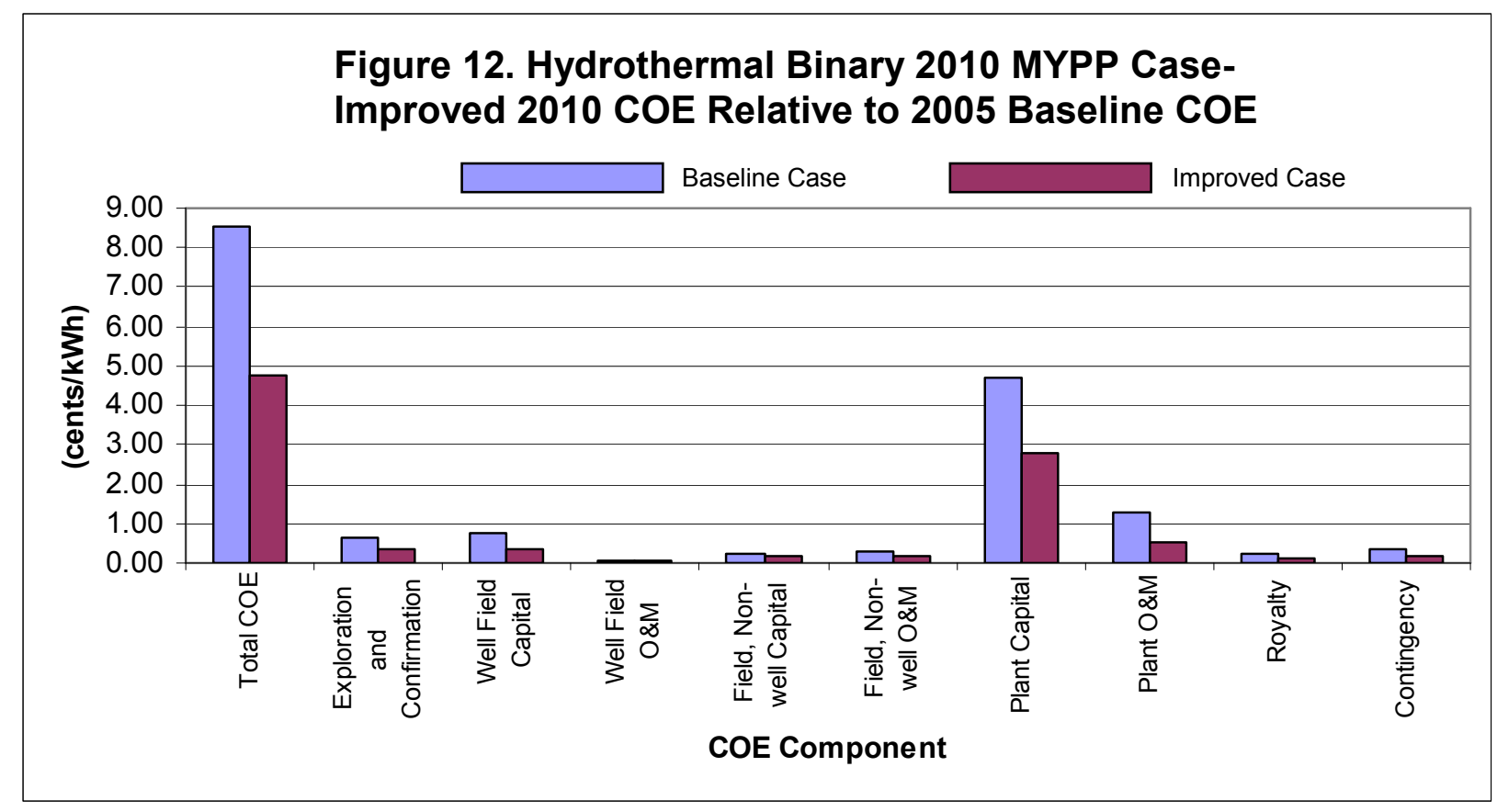

Figure 13 reinforces the notion that the MYPP Case shows little uncertainty above and below the expected LCOE improvements, as reflected in the small differences between the mean and maximum improvements. Again, the issue of hitting the caps implemented in the model limits the apparent additivity of the individual TIOs, as previously discussed. 


\section{Figure 13. Hydrothermal Binary 2010 MYPP - Improvements to COE Range}

ALL TIOs + Pow er Plant Unit Reduction Pow er Plant Unit Reduction ALLTIOs

T10 1 - Target Temperature Prediction TIO 2 - Fractures, Proppants, Rheology TIO 3 - Fracture Control/Packer's TIO 4 - Fracture Prediction Modeling T10 5 - Subsurface Circulation System TIO 6 - Reservoir Performance Modeling TIO 7 - Artificial Lift T10 8 - Short Circuit Mitigation TIO 9 - Technical Systems Analysis T10 10 - Remote Sensing T10 11 - Geophysics T10 12 - Geochemistry T10 13 - Resource Assessment

TIO 14 - Drilling Time Reduction 5- Wellbore Lining Reduction TIO 16 - Flat Time Reduction -1 T10 17 - Instrumentation, Testing, T10 18 - Completion \& Production TOO 19 - Cycle Related T10 20 - Component Related TIO 21 - Monitoring \& Scaling

TIO 22 - Design/Construction Related TIO 23 - Automation/Enhanced Controls

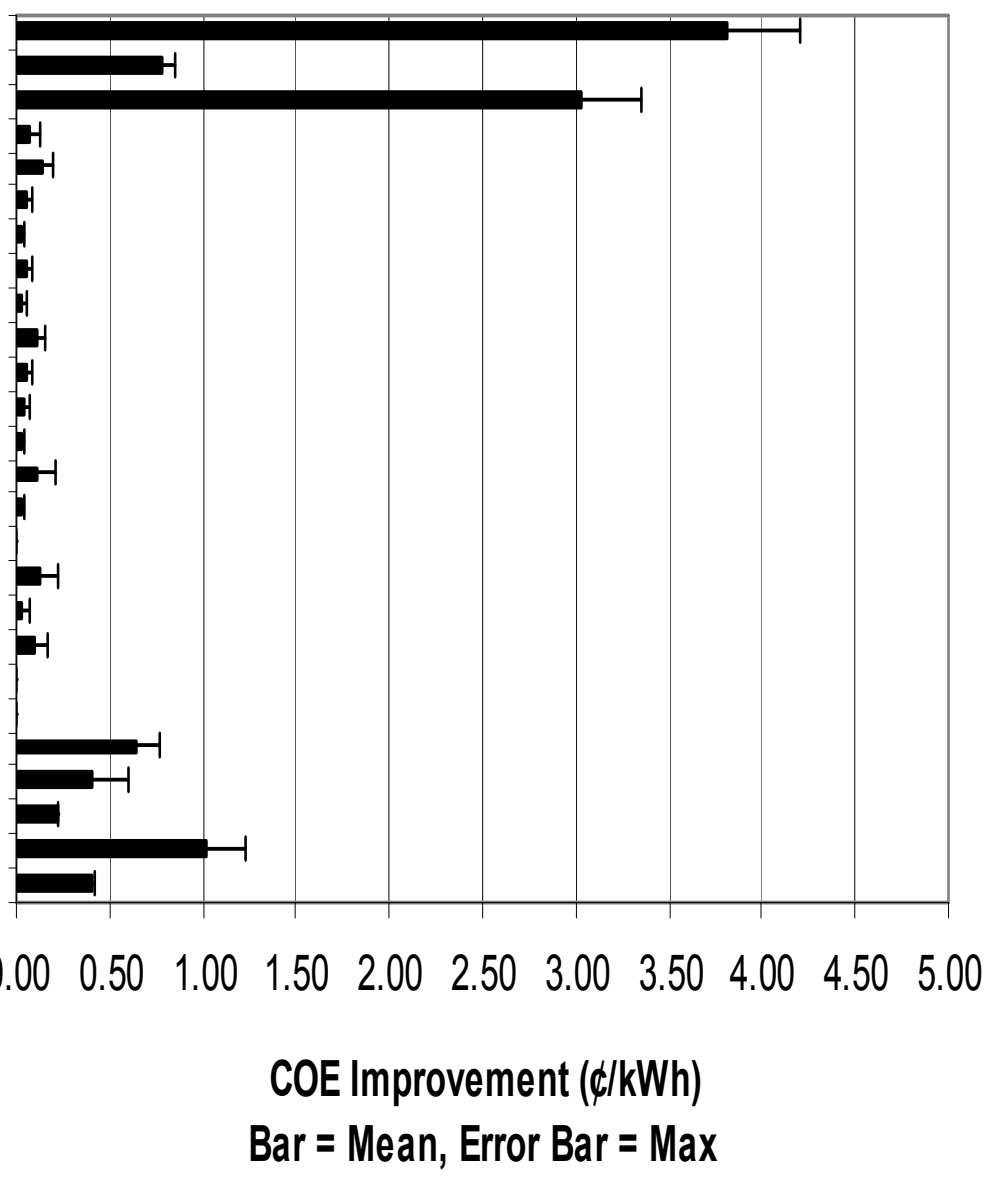




\section{EGS Binary 2010 MYPP Case}

Figure 14 shows that the EGS Binary 2010 MYPP Case is very similar to the EGS Binary 2010 Experts Case, but the MYPP case has a much narrower distribution of LCOE improvements (as seen in Figures F3 and F7 in Appendix F). As with the preceding MYPP Hydrothermal Binary case, this results from the assumptions governing the construction of the ranges of improvements for the MYPP case. Despite the fact that the Expert Case predicts greater improvements for both the mean and maximum improvements, neither the MYPP estimates nor the Experts estimates for the EGS Binary 2010 Cases suggests that $5 \phi / \mathrm{kWh}$ is reachable by 2010 . However, both the MYPP and Experts estimates suggest substantial (i.e., about $50 \%$ or more) improvements can be made in by the 2010 time frame.

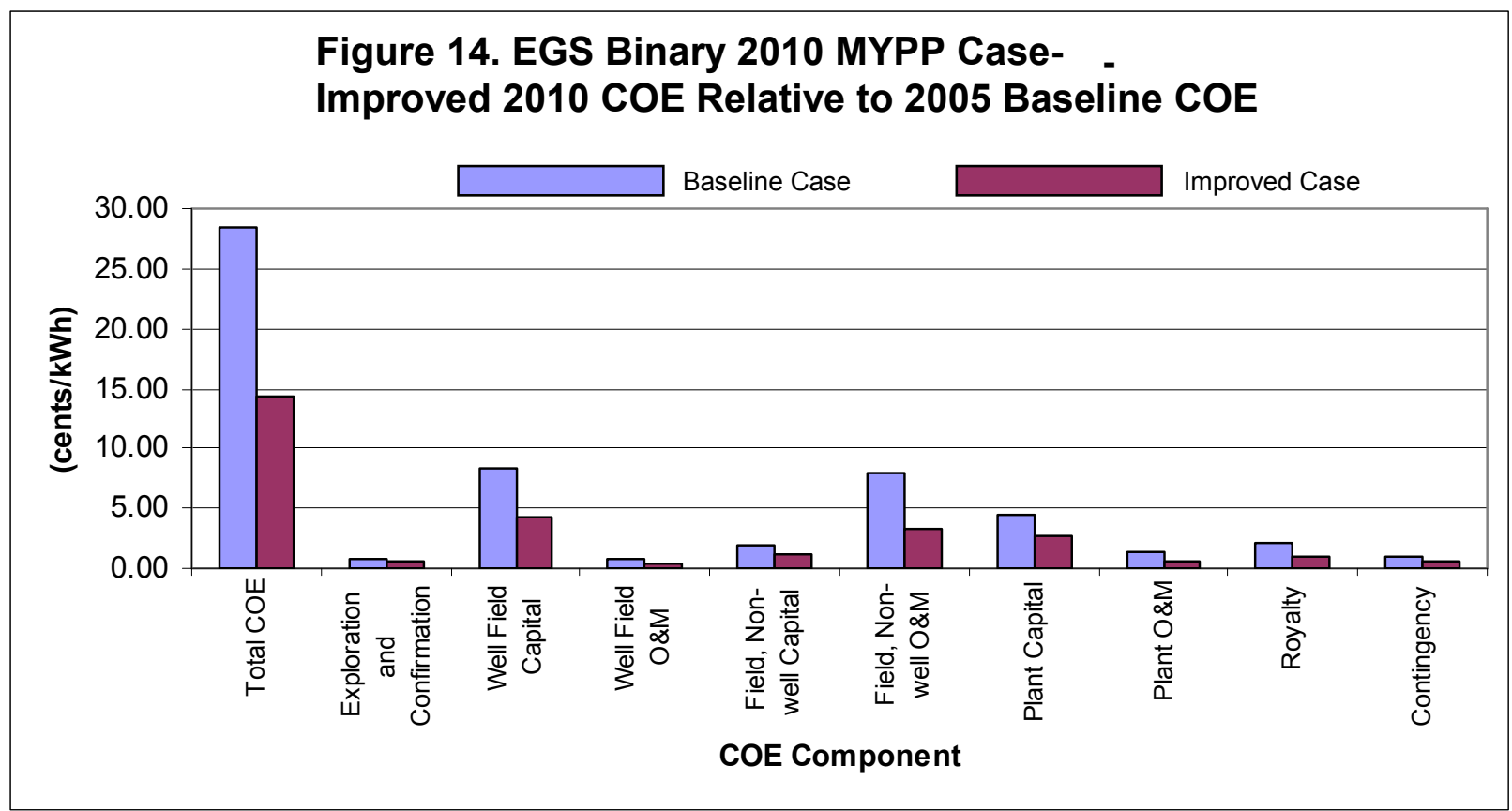

Figure 15, similar to Figure 13, shows that the MYPP cases have less uncertainty in the LCOE reductions than the matching ranges for the Expert Case. This applies to the composite TIOs, as well as to the standalone TIO improvements. 


\section{Figure 15. EGS Binary 2010 MYPP - Improvements to COE Range}

ALL TIOs + Pow er Plant Unit Reduction Pow er Plant Unit Reduction

ALL TIOs

T10 1 - Target Temperature Prediction

TIO 2 - Fractures, Proppants, Rheology

TIO 3 - Fracture Control/Packers

TIO 4 - Fracture Prediction Modeling

T10 5 - Subsurface Circulation System -1

TIO 6 - Reservoir Performance Modeling

TIO 8 - Short Circuit Mitigation

TIO 9 - Technical Systems Analysis

TIO 10 - Remote Sensing

T10 11 - Geophysics

T10 12 - Geochemistry

T10 13 - Resource Assessment

TIO 14 - Drilling Time Reduction

TIO 15 - Wellbore Lining Reduction

TIO 16 - Flat Time Reduction

TIO 17 - Instrumentation, Testing,

TI0 18 - Completion \& Production

TIO 19 - Cycle Related TIO 20 - Component Related TIO 21 - Monitoring \& Scaling

TIO 22 - Design/Construction Related TIO 23 - Automation/Enhanced Controls

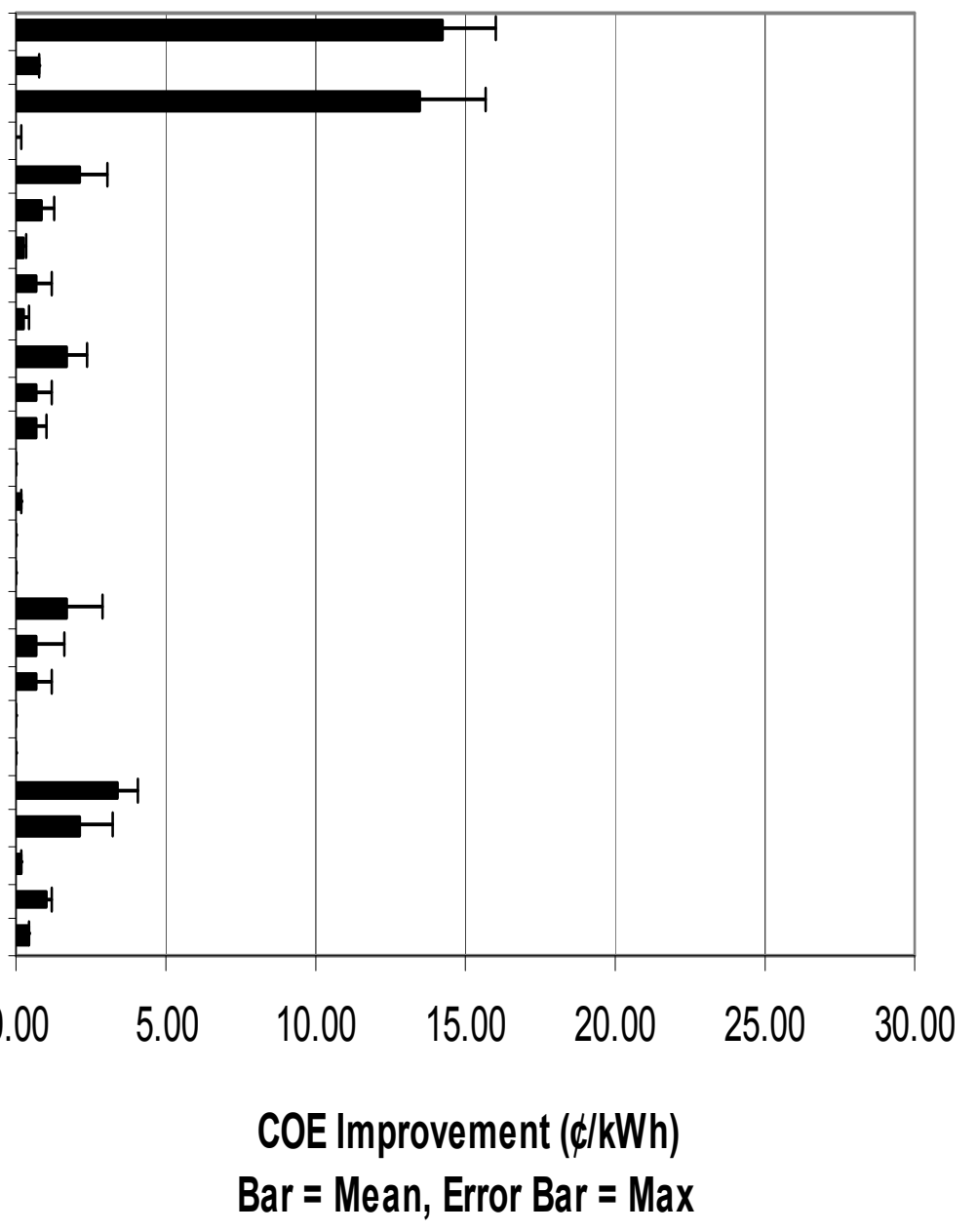


Appendix A: Hydrothermal Binary Power System Case - Inputs

\begin{tabular}{|c|c|c|c|}
\hline Global Economic Parameters & Unit & Baseline & Input Category \\
\hline Fixed Charge Rate & Ratio & 0.128 & Plug \\
\hline Utilization Factor & Ratio & 0.95 & TPM \\
\hline Contingency & $\%$ & $5 \%$ & Plug \\
\hline \multicolumn{4}{|l|}{ Input parameters } \\
\hline Temperature of GT Fluid in Reservoir & Deg-C & 150 & Case \\
\hline Plant Size (Exclusive of Brine Pumping) & $\mathrm{MW}(\mathrm{e})$ & 30.0 & Case \\
\hline Number of independent power units & & 3 & Case \\
\hline $\begin{array}{r}\text { Brine Effectiveness (exclusive of brine } \\
\text { pumping) }\end{array}$ & $\begin{array}{l}\text { Calculate } \\
\text { Y or N }\end{array}$ & $\mathbf{Y}$ & Case \\
\hline If $\mathrm{N}(\mathrm{no})$, enter value in cell $\mathrm{C} 19$ and/or E19 & $\mathrm{W}-\mathrm{h} / \mathrm{lb}$ & & Case \\
\hline Calculated Brine Effectiveness & $\mathrm{W}-\mathrm{h} / \mathrm{lb}$ & 4.63 & Calc \\
\hline Brine Effectiveness & W-h/lb & 4.63 & TPM \\
\hline $\begin{array}{l}\text { Apply improvement to reducing flow } \\
\text { requirement or increasing power output }\end{array}$ & $\begin{array}{l}\mathrm{F} \text { - flow or } \\
\mathrm{P} \text { - power }\end{array}$ & $\mathbf{P}$ & Case \\
\hline Plant Cost & $\begin{array}{l}\text { Calculate } \\
\text { or N }\end{array}$ & $\mathbf{Y}$ & Case \\
\hline If $\mathrm{N}$ (no), enter value in cell $\mathrm{C} 24$ and/or E24 & $\$ / \mathrm{kW}$ & - & Case \\
\hline Calculated Plant Cost & $\$ / \mathrm{kW}$ & $\$ 2,445$ & Calc \\
\hline Plant Cost & $\$ / \mathrm{kW}$ & $\$ 2,445$ & TPM \\
\hline Wells Cost Curve: $1=$ Low, 2=Med, 3=High & & 2 & Case \\
\hline PRODUCTION WELL Depth & Feet & 5,000 & Case \\
\hline Estimated Cost, from SNL Curve & \$K/well & $\$ 1,222$ & Calc \\
\hline User's Cost Curve Multiplier & ratio & 1.00 & Case \\
\hline Producer, Final Cost & $\$ \mathrm{~K} /$ well & $\$ 1,222$ & TPM \\
\hline INJECTION WELL Depth & Feet & 5,000 & Case \\
\hline Estimated Cost, from SNL Curve & $\$ \mathrm{~K} /$ well & $\$ 1,222$ & Calc \\
\hline Injector, Final Cost & \$K/well & $\$ 1,222$ & TPM \\
\hline Surface Equip Cost/Well & \$K/well & $\$ 100$ & TPM \\
\hline Exploration Success & Ratio & 0.20 & TPM \\
\hline Power Found & MW(e) & 50 & Case \\
\hline Number of Confirmation wells & Count & 3 & Case \\
\hline Confirmation Success & Ratio & 0.60 & TPM \\
\hline Injector/Producer & Ratio & 0.50 & Case \\
\hline Spare Prods & Count & - & Case \\
\hline Well stimulation & $\begin{array}{l}\text { Y- yes or } \\
\mathrm{N}-\text { no }\end{array}$ & $\mathbf{N}$ & Case \\
\hline Stimulation cost & \$K/well & $\$ 500$ & TPM \\
\hline GF Pump Efficiency & & $80 \%$ & Case \\
\hline Pump type & $\begin{array}{l}\mathrm{L}=\text { lineshaft; } \\
\mathrm{S}=\text { submersible }\end{array}$ & $\mathbf{L}$ & Case \\
\hline Flow per LINESHAFT pump & gpm/well & 2,000 & TPM \\
\hline
\end{tabular}




\begin{tabular}{|c|c|c|c|}
\hline Global Economic Parameters & Unit & Baseline & Input Category \\
\hline Inputted pump depth & $\mathrm{ft}$ & 1,000 & Case \\
\hline Lineshaft pump cost & \$K & $\$ 250$ & Case \\
\hline Flow per SUBMERSIBLE pump & gpm/well & 2,250 & Case \\
\hline Additional drawdown for flow $>1500$ gpm & $\mathrm{ft} / 100 \mathrm{gpm}$ & - & Case \\
\hline Pump depth & $\mathrm{ft}$ & 1,000 & Calc \\
\hline Submersible pump cost & $\$ K$ & $\$ 250$ & Plug \\
\hline Injection pump dP & psi & 100 & Plug \\
\hline Injection pump cost & $\$ / h p$ & $\$ 700$ & Plug \\
\hline Temperature Drawdown Rate: Input & $\% /$ year & $\mathbf{0 . 3 0}$ & TPM \\
\hline Result A: Life of nominal reservoir & years & 30 & Calc \\
\hline Result B: Loss of discounted revenue & $\%$ & $8.1 \%$ & Calc \\
\hline $\begin{array}{r}\text { Annual O\&M non-labor (fraction of plant } \\
\text { cost) }\end{array}$ & $\%$ & $1.5 \%$ & TPM \\
\hline $\begin{array}{r}\text { Annual O\&M non-labor (fraction of field } \\
\text { cost) }\end{array}$ & $\%$ & $1.0 \%$ & Plug \\
\hline Number of O\&M staff & $\#$ & 14.6 & TPM \\
\hline
\end{tabular}


Appendix B: Hydrothermal Flashed-Steam Power System Case - Inputs

\begin{tabular}{|c|c|c|c|}
\hline Global Economic Parameters & Unit & Baseline & Input Category \\
\hline Fixed Charge Rate & Ratio & 0.128 & Plug \\
\hline Utilization Factor & Ratio & 0.90 & TPM \\
\hline Contingency & $\%$ & $5 \%$ & Plug \\
\hline \multicolumn{4}{|l|}{ Input parameters } \\
\hline Temperature of GT Fluid in Reservoir & Deg-C & 200 & Case \\
\hline ncg level ( based on total flow) & $\mathrm{ppm}$ & 200 & Case \\
\hline H2S level (based on total flow) & $\mathrm{ppm}$ & 2 & Case \\
\hline Number of flashes & $\begin{array}{l}1=1 \text { flash, } \\
2=2 \text { flash }\end{array}$ & 2 & Case \\
\hline Plant Size (Exclusive of Brine Pumping) & MW(e) & 50.0 & Case \\
\hline Number of independent power units & & 1 & Case \\
\hline Condenser type & $\begin{array}{c}\mathrm{S}=\text { surface} \\
\mathrm{DC}=\text { direct } \\
\text { contact }\end{array}$ & $\mathbf{S}$ & Case \\
\hline NCG Removal & $\begin{array}{c}\mathrm{J}=\text { jet; } \\
\mathrm{VP}=\mathrm{vac} \\
\text { pump }\end{array}$ & $\mathbf{V P}$ & Case \\
\hline $\begin{array}{r}\text { Brine Effectiveness (exclusive of brine } \\
\text { pumping) }\end{array}$ & $\begin{array}{l}\text { Calculate } \\
\text { Y or N }\end{array}$ & $\mathbf{Y}$ & Case \\
\hline If N (no), enter value in cell C24 and/or E24 & $\mathrm{W}-\mathrm{h} / \mathrm{lb}$ & & Case \\
\hline $\begin{array}{r}\text { Calculated Brine Effectiveness (net, no } \\
\text { pumping) }\end{array}$ & $\mathrm{W}-\mathrm{h} / \mathrm{lb}$ & 9.40 & Calc \\
\hline Brine Effectiveness (net) & W-h/lb & 9.40 & TPM \\
\hline $\begin{array}{l}\text { Apply improvement to reducing flow } \\
\text { requirement or increasing power output }\end{array}$ & $\begin{array}{l}\mathrm{F} \text { - flow or } \\
\mathrm{P} \text { - power }\end{array}$ & $\mathbf{P}$ & Case \\
\hline Plant Cost & $\begin{array}{l}\text { Calculate } \\
\text { Y or N }\end{array}$ & $\mathbf{Y}$ & Case \\
\hline If $\mathrm{N}$ (no), enter value in cell $\mathrm{C} 29$ and/or E29 & $\$ / \mathrm{kW}$ & - & Case \\
\hline Equipment cost multiplier for installed cost & & 2.53 & Plug \\
\hline Calculated Plant Cost & $\$ / \mathrm{kW}$ & $\$ 995$ & Calc \\
\hline Plant Cost & $\$ / \mathrm{kW}$ & $\$ 995$ & TPM \\
\hline Wells Cost Curve: $1=$ Low, $2=$ Med, $3=$ High & & 2 & Case \\
\hline PRODUCTION WELL Depth & Feet & 8,000 & Case \\
\hline Estimated Cost, from SNL Curve & $\$ \mathrm{~K} /$ well & $\$ 1,910$ & Calc \\
\hline User's Cost Curve Multiplier & ratio & 1.00 & Case \\
\hline Producer, Final Cost & $\$ \mathrm{~K} /$ well & $\$ 1,910$ & TPM \\
\hline INJECTION WELL Depth & Feet & 8,000 & Case \\
\hline Estimated Cost, from SNL Curve & \$K/well & $\$ 1,910$ & Calc \\
\hline Injector, Final Cost & $\$ \mathrm{~K} /$ well & $\$ 1,910$ & TPM \\
\hline Surface Equip Cost/Well & $\$ \mathrm{~K} /$ well & $\$ 100$ & TPM \\
\hline Exploration Success & Ratio & 0.20 & TPM \\
\hline Power Found & MW(e) & 100 & Case \\
\hline Number of Confirmation wells & Count & 4 & Case \\
\hline
\end{tabular}




\begin{tabular}{|c|c|c|c|}
\hline Global Economic Parameters & Unit & Baseline & Input Category \\
\hline Confirmation Success & Ratio & 0.60 & TPM \\
\hline Injector/Producer & Ratio & 0.50 & Case \\
\hline Spare Prods & Count & - & Case \\
\hline Well stimulation & $\begin{array}{l}\text { Y-yes or } \\
\mathrm{N}-\text { no }\end{array}$ & $\mathbf{N}$ & Case \\
\hline Stimulation cost & \$K/well & $\$ 300$ & TPM \\
\hline Wells Pumped & $\begin{array}{l}\text { Y-yes or } \\
\mathrm{N}-\text { no }\end{array}$ & $\mathbf{N}$ & Case \\
\hline Unpumped well flow rate & $\mathrm{lb} / \mathrm{h}$ & 500,000 & Case \\
\hline GF Pump Efficiency & & $9999 \%$ & Case \\
\hline Pump type & $\begin{array}{c}\mathrm{L}=\text { lineshaft; } \\
\mathrm{S}=\text { submersibl } \\
\mathrm{e}\end{array}$ & $\mathbf{L}$ & Case \\
\hline Flow per LINESHAFT pump & gpm/well & 900 & TPM \\
\hline Inputted pump depth & $\mathrm{ft}$ & 2,000 & Case \\
\hline Lineshaft pump cost & $\$ \mathrm{~K}$ & $\$ 300$ & Case \\
\hline Flow per SUBMERSIBLE pump & gpm/well & 2,250 & Case \\
\hline Additional drawdown for flow $>1500$ gpm & $\mathrm{ft} / 100 \mathrm{gpm}$ & - & Case \\
\hline Revised pump depth & $\mathrm{ft}$ & 2,000 & Calc \\
\hline Submersible pump cost & $\$ K$ & $\$ 250$ & Plug \\
\hline Injection pump dP & psi & 100 & Plug \\
\hline Injection pump cost & $\$ / h p$ & $\$ 700$ & Plug \\
\hline Drawdown Rate for Flow/Well: $\quad$ Input: & $\% /$ year & 2.00 & TPM \\
\hline Result A: Discounted No. of Makeup Wells & number & 1.3 & Calc \\
\hline Result B: Loss of discounted revenue & $\%$ & $5.5 \%$ & Calc \\
\hline $\begin{array}{r}\text { Annual O\&M non-labor (fraction of plant } \\
\text { cost) }\end{array}$ & $\%$ & $1.5 \%$ & TPM \\
\hline $\begin{array}{r}\text { Annual O\&M non-labor (fraction of field } \\
\text { cost) }\end{array}$ & $\%$ & $1.0 \%$ & Plug \\
\hline Number of O\&M staff & \# & 16.3 & TPM \\
\hline
\end{tabular}


Appendix C: EGS Binary Power System Case - Inputs

\begin{tabular}{|c|c|c|c|}
\hline Global Economic Parameters & Unit & Baseline & Input Category \\
\hline Fixed Charge Rate & Ratio & 0.128 & Plug \\
\hline Utilization Factor & Ratio & 0.95 & TPM \\
\hline Contingency & $\%$ & $5 \%$ & Plug \\
\hline \multicolumn{4}{|l|}{ Input parameters } \\
\hline Temperature of GT Fluid in Reservoir & Deg-C & 200 & Case \\
\hline Plant Size (Exclusive of Brine Pumping) & MW(e) & 30 & Case \\
\hline Number of independent power units & & 3 & Case \\
\hline $\begin{array}{r}\text { Brine Effectiveness (exclusive of brine } \\
\text { pumping) }\end{array}$ & $\begin{array}{l}\text { Calculate } \\
\text { Y or N }\end{array}$ & $\mathbf{Y}$ & Case \\
\hline $\begin{array}{r}\text { If } \mathrm{N}(\mathrm{no}), \text { enter value in cell } \mathrm{C} 19 \text { and/or } \\
\mathrm{E} 19\end{array}$ & $\mathrm{~W}-\mathrm{h} / \mathrm{lb}$ & & Case \\
\hline Calculated Brine Effectiveness & $\mathrm{W}-\mathrm{h} / \mathrm{lb}$ & 10.86 & Calc \\
\hline Brine Effectiveness & $\mathrm{W}-\mathrm{h} / \mathrm{lb}$ & 10.86 & TPM \\
\hline $\begin{array}{l}\text { Apply improvement to reducing flow } \\
\text { requirement or increasing power output }\end{array}$ & $\begin{array}{l}\mathrm{F} \text { - flow or } \\
\mathrm{P} \text { - power }\end{array}$ & $\mathbf{P}$ & Case \\
\hline Plant Cost & $\begin{array}{l}\text { Calculate } \\
\text { Y or N }\end{array}$ & $\mathbf{Y}$ & Case \\
\hline $\begin{array}{r}\text { If } \mathrm{N} \text { (no), enter value in cell } \mathrm{C24} \text { and/or } \\
\text { E24 }\end{array}$ & $\$ / \mathrm{kW}$ & - & Case \\
\hline Calculated Plant Cost & $\$ / \mathrm{kW}$ & $\$ 2,140$ & Calc \\
\hline Plant Cost & $\$ / \mathrm{kW}$ & $\$ 2,140$ & TPM \\
\hline Wells Cost Curve: $\quad$ =Low, $2=$ Med, $3=$ High & & 2 & Case \\
\hline PRODUCTION WELL Depth & Feet & 13,123 & Case \\
\hline Estimated Cost, from SNL Curve & \$K/well & $\$ 4,098$ & Calc \\
\hline User's Cost Curve Multiplier & ratio & 1.20 & Case \\
\hline $\begin{array}{r}\text { Producer, Final Cost } \\
\end{array}$ & \$K/well & $\$ 4,918$ & TPM \\
\hline INJECTION WELL Depth & Feet & 13,123 & Case \\
\hline Estimated Cost, from SNL Curve & \$K/well & $\$ 4,098$ & Calc \\
\hline Injector, Final Cost & \$K/well & $\$ 4,918$ & TPM \\
\hline Surface Equip Cost/Well & $\$ \mathrm{~K} /$ well & $\$ 100$ & TPM \\
\hline Exploration Success & Ratio & 0.80 & TPM \\
\hline Power Found & MW(e) & 600 & Case \\
\hline Number of Confirmation wells & Count & 2 & Case \\
\hline Confirmation Success & Ratio & 0.80 & TPM \\
\hline Injector/Producer & Ratio & $\mathbf{0 . 3 3}$ & Case \\
\hline Spare Prods & Count & - & Case \\
\hline Well stimulation & $\begin{array}{l}\text { Y- yes or } \\
\mathrm{N}-\text { no }\end{array}$ & $\mathbf{Y}$ & Case \\
\hline Stimulation cost & $\$ \mathrm{~K} /$ well & $\$ 750$ & TPM \\
\hline GF Pump Efficiency & & $80 \%$ & Case \\
\hline Pump type & $\begin{array}{c}\mathrm{L}=\text { lineshaft; } \\
\mathrm{S}=\text { submersible }\end{array}$ & $\mathbf{L}$ & Case \\
\hline
\end{tabular}




\begin{tabular}{|r|c|c|c|}
\hline \multicolumn{1}{|c|}{ Global Economic Parameters } & Unit & Baseline & Input Category \\
\hline Flow per LINESHAFT pump & $\mathrm{gpm} / \mathrm{well}$ & $\mathbf{3 3 2}$ & TPM \\
\hline Inputted pump depth & $\mathrm{ft}$ & $\mathbf{2 , 0 0 0}$ & Case \\
\hline Lineshaft pump cost & $\$ \mathrm{~K}$ & $\mathbf{\$ 3 0 0}$ & Case \\
\hline Flow per SUBMERSIBLE pump & $\mathrm{gpm} / \mathrm{well}$ & $\mathbf{3 9 5}$ & Case \\
\hline Additional drawdown for flow>1500 gpm & $\mathrm{ft} / 100 \mathrm{gpm}$ & - & Case \\
\hline Pump depth & $\mathrm{ft}$ & $\mathbf{2 , 0 0 0}$ & Calc \\
\hline Submersible pump cost & $\$ \mathrm{~K}$ & $\mathbf{\$ 2 5 0}$ & Plug \\
\hline Injection pump dP & $\mathrm{psi}$ & $\mathbf{1 0 0}$ & Plug \\
\hline Injection pump cost & $\$ / \mathrm{hp}$ & $\mathbf{7 0 0}$ & Plug \\
\hline Temperature Drawdown Rate: Input & $\% / \mathrm{year}$ & $\mathbf{3 . 0}$ & TPM \\
\hline Result A: Life of nominal reservoir & $\mathrm{years}$ & $\mathbf{6}$ & Calc \\
\hline Result B: Loss of discounted revenue & $\%$ & $\mathbf{1 8 . 4} \%$ & Calc \\
\hline Annual O\&M non-labor (fraction of plant & $\%$ & & \\
\hline cost) & & & TPM \\
\hline cost) & $\%$ & $\mathbf{1 . 5} \%$ & Plug \\
\hline
\end{tabular}


Appendix D: EGS Flashed-Steam Power System Case - Inputs

\begin{tabular}{|c|c|c|c|}
\hline Global Economic Parameters & Unit & Baseline & Input Category \\
\hline Fixed Charge Rate & Ratio & 0.128 & Plug \\
\hline Utilization Factor & Ratio & 0.90 & TPM \\
\hline Contingency & $\%$ & $5 \%$ & Plug \\
\hline \multicolumn{4}{|l|}{ Input parameters } \\
\hline Temperature of GT Fluid in Reservoir & Deg-C & 250 & Case \\
\hline ncg level ( based on total flow) & ppm & 200 & Case \\
\hline H2S level (based on total flow) & ppm & 2 & Case \\
\hline Number of flashes & $\begin{array}{l}1=1 \text { flash, } \\
2=2 \text { flash }\end{array}$ & 2 & Case \\
\hline Plant Size (Exclusive of Brine Pumping) & MW(e) & 50 & Case \\
\hline Number of independent power units & & 1 & Case \\
\hline Condenser type & $\begin{array}{c}\mathrm{S}=\text { surface} ; \\
\mathrm{DC}=\text { direct } \\
\text { contact }\end{array}$ & $\mathbf{S}$ & Case \\
\hline NCG Removal & $\begin{array}{c}\mathrm{J}=\text { jet; } \\
\mathrm{VP}=\mathrm{vac} \text { pump }\end{array}$ & VP & Case \\
\hline $\begin{array}{r}\text { Brine Effectiveness (exclusive of brine } \\
\text { pumping) }\end{array}$ & $\begin{array}{l}\text { Calculate } \\
\text { Y or N }\end{array}$ & $\mathbf{Y}$ & Case \\
\hline $\begin{array}{r}\text { If } \mathrm{N}(\mathrm{no}), \text { enter value in cell } \mathrm{C} 24 \text { and/or } \\
\text { E24 }\end{array}$ & $\mathrm{W}-\mathrm{h} / \mathrm{lb}$ & & Case \\
\hline $\begin{array}{r}\text { Calculated Brine Effectiveness (net, no } \\
\text { pumping) }\end{array}$ & $\mathrm{W}-\mathrm{h} / \mathrm{lb}$ & 16.28 & Calc \\
\hline Brine Effectiveness (net) & $\mathrm{W}-\mathrm{h} / \mathrm{lb}$ & 16.28 & TPM \\
\hline $\begin{array}{l}\text { Apply improvement to reducing flow } \\
\text { requirement or increasing power output }\end{array}$ & $\begin{array}{l}\mathrm{F} \text { - flow or } \\
\mathrm{P} \text { - power }\end{array}$ & $\mathbf{P}$ & Case \\
\hline Plant Cost & $\begin{array}{l}\text { Calculate } \\
\text { Y or } \mathrm{N}\end{array}$ & $\mathbf{Y}$ & Case \\
\hline $\begin{array}{r}\text { If } \mathrm{N}(\mathrm{no}), \text { enter value in cell } \mathrm{C29} \text { and/or } \\
\text { E29 }\end{array}$ & $\$ / \mathrm{kW}$ & - & Case \\
\hline Equipment cost multiplier for installed cost & & 2.53 & Plug \\
\hline Calculated Plant Cost & $\$ / \mathrm{kW}$ & $\$ 940$ & Calc \\
\hline Plant Cost & $\$ / \mathrm{kW}$ & $\$ 940$ & TPM \\
\hline 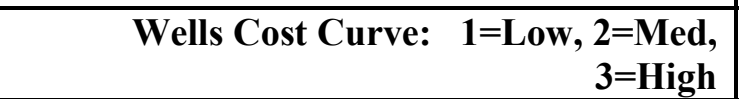 & & 2 & Case \\
\hline PRODUCTION WELL Depth & Feet & 19,685 & Case \\
\hline Estimated Cost, from SNL Curve & $\$ \mathrm{~K} /$ well & $\$ 10,895$ & Calc \\
\hline User's Cost Curve Multiplier & ratio & 1.15 & Case \\
\hline Producer, Final Cost & \$K/well & $\$ 12,530$ & TPM \\
\hline INJECTION WELL Depth & Feet & 19,685 & Case \\
\hline Estimated Cost, from SNL Curve & \$K/well & $\$ 10,895$ & Calc \\
\hline Injector, Final Cost & $\$ \mathrm{~K} /$ well & $\$ 12,530$ & TPM \\
\hline Surface Equip Cost/Well & $\$ \mathrm{~K} /$ well & $\$ 100$ & TPM \\
\hline
\end{tabular}




\begin{tabular}{|c|c|c|c|}
\hline Global Economic Parameters & Unit & Baseline & Input Category \\
\hline Exploration Success & Ratio & 0.80 & TPM \\
\hline Power Found & MW(e) & 600 & Case \\
\hline Number of Confirmation wells & Count & 2 & Case \\
\hline Confirmation Success & Ratio & $\mathbf{0 . 8 0}$ & TPM \\
\hline Injector/Producer & Ratio & 0.33 & Case \\
\hline Spare Prods & Count & - & Case \\
\hline Well stimulation & $\begin{array}{l}\text { Y-yes or } \\
\mathrm{N}-\text { no }\end{array}$ & $\mathbf{Y}$ & Case \\
\hline Stimulation cost & \$K/well & $\$ 750$ & TPM \\
\hline Wells Pumped & $\begin{array}{l}\text { Y-yes or } \\
\mathrm{N}-\text { no }\end{array}$ & $\mathbf{Y}$ & Case \\
\hline Unpumped well flow rate & $\mathrm{lb} / \mathrm{h}$ & 118,000 & Case \\
\hline GF Pump Efficiency & & $80 \%$ & Case \\
\hline Pump type & $\begin{array}{c}\mathrm{L}=\text { lineshaft; } \\
\mathrm{S}=\text { submersible }\end{array}$ & $\mathbf{L}$ & Case \\
\hline Flow per LINESHAFT pump & gpm/well & 332 & TPM \\
\hline Inputted pump depth & $\mathrm{ft}$ & 2,000 & Case \\
\hline Lineshaft pump cost & $\$ K$ & $\$ 300$ & Case \\
\hline Flow per SUBMERSIBLE pump & gpm/well & 395 & Case \\
\hline Additional drawdown for flow $>1500$ gpm & $\mathrm{ft} / 100 \mathrm{gpm}$ & - & Case \\
\hline Revised pump depth & $\mathrm{ft}$ & 2,000 & Calc \\
\hline Submersible pump cost & $\$ K$ & $\$ 250$ & Plug \\
\hline Injection pump dP & psi & 100 & Plug \\
\hline Injection pump cost & $\$ / h p$ & 700 & Plug \\
\hline $\begin{array}{r}\text { Drawdown Rate for Flow/Well: } \\
\text { Input: }\end{array}$ & $\% /$ year & 15.0 & TPM \\
\hline Result A: Discounted No. of Makeup Wells & number & 11.8 & Calc \\
\hline Result B: Loss of discounted revenue & $\%$ & $10.2 \%$ & Calc \\
\hline $\begin{array}{r}\text { Annual O\&M non-labor (fraction of plant } \\
\text { cost) }\end{array}$ & $\%$ & $1.5 \%$ & TPM \\
\hline $\begin{array}{r}\text { Annual O\&M non-labor (fraction of field } \\
\text { cost) }\end{array}$ & $\%$ & $1.0 \%$ & Plug \\
\hline Number of O\&M staff & \# & 16.3 & ТPM \\
\hline
\end{tabular}




\section{Appendix E: Consensus Expert Team Scoring Matrices}

\section{Risk Cases Considered}

Seven cases were evaluated for this risk analysis. The Geothermal Expert Team scored the TIO-TPM impacts for five separate cases:

1. Hydrothermal Binary 2010

2. Hydrothermal Flash 2010

3. EGS Binary 2010

4. EGS Flash 2010

5. EGS Binary Evolutionary 2040

Analysts also specifically sought to compare the projections of the Expert Team initiating this risk assessment protocol with the prior planning projections of the GTP. To do this, two additional cases were developed to evaluate the improvements projected by the GTP research teams in the 2005 MYPP:

6. Hydrothermal Binary 2010 MYPP

7. EGS Binary 2010 MYPP

The following Excel printout lists the five sets of the Expert Team's consensus scoring on expected research gains for geothermal technology. The scoring derived from the MYPP also is listed in the last two sets of printout sheets.

The four GETEM reference cases displayed in Appendices A through D provided the baseline input data profiles for these seven risk cases. The baseline data in Appendices A through D are allocated to the risk cases by corresponding subject: e.g., Hydrothermal Binary, EGS Flash, etc. 


\begin{tabular}{|c|c|c|c|c|c|c|c|c|}
\hline \multirow[b]{3}{*}{ TIO Categories } & \multirow[b]{3}{*}{ GETEM INPUTS/TPMS } & \multicolumn{7}{|c|}{ HYDROTHERMAL BINARY 2010- SYSTEM SCORING SHEET } \\
\hline & & \multirow[b]{2}{*}{ Units } & \multirow{2}{*}{\begin{tabular}{|l|} 
Baseline \\
in 2005
\end{tabular}} & \multicolumn{3}{|c|}{ TIO Improvements in 2010 in \% } & \multirow{2}{*}{$\begin{array}{c}\text { Prob. of } \\
\text { Success \% }\end{array}$} & \multirow[b]{2}{*}{ Comments } \\
\hline & & & & Minimum \% & Expected \% & Maximum \% & & \\
\hline \multirow{13}{*}{$\begin{array}{l}\text { TIO 1-Increase } \\
\text { accuracy of target } \\
\text { temperature } \\
\text { prediction }\end{array}$} & Utilization Factor & & & & & & & \\
\hline & Brine Effectiveness & W-h/lb & 4.63 & & & & & \\
\hline & Plant Cost & $\$ \mathrm{~s} / \mathrm{kW}$ & 2,445 & & & & & \\
\hline & Production Well Cost & SK/well & 1,222 & & & & & \\
\hline & Injector Well Cost & \$K/well & 1,222 & & & & & \\
\hline & Surface Equipment Cost & \$K/well & 100 & & & & & \\
\hline & Exploration Success & Ratio & 0.20 & $1.0 \%$ & $5.0 \%$ & $7.0 \%$ & $90 \%$ & Assumed that this EGS TIO impacts the HT case at $100 \%$ of the EGS case. \\
\hline & Confirmation Success & Ratio & 0.60 & $1.0 \%$ & $2.0 \%$ & $4.0 \%$ & $90 \%$ & Assumed that this EGS TIO impacts the HT case at $100 \%$ of the EGS case. \\
\hline & Stimulation Cost & \$K/well & 500 & & & & & \\
\hline & Production Well Flow Rate & gpm/well & 2,000 & & & & & \\
\hline & Temperature Drawdown Rate & \%/year & $0.30 \%$ & & & & & \\
\hline & Annual O\&M non-labor & $\%$ & $1.5 \%$ & & & & & \\
\hline & Number of O\&M staff & \# & 14.6 & & & & & \\
\hline \multirow{13}{*}{$\begin{array}{l}\text { TIO 2- Improve } \\
\text { fracture methods, } \\
\text { proppants and } \\
\text { rheology }\end{array}$} & \begin{tabular}{|l} 
Utilization Factor \\
\end{tabular} & $\%$ & $95 \%$ & & & & & \\
\hline & Brine Effectiveness & W-h/lb & 4.63 & & & & & \\
\hline & Plant Cost & $\$ / k W$ & 2,445 & & & & & \\
\hline & Production Well Cost & \$K/well & 1,222 & & & & & \\
\hline & Injector Well Cost & SK/well & 1,222 & & & & & \\
\hline & Surface Equipment Cost & \$K/well & 100 & & & & & \\
\hline & Exploration Success & Ratio & 0.20 & & & & & \\
\hline & Confirmation Success & Ratio & 0.60 & & & & & Assumed that this EGS TIO impacts the HT case at $25 \%$ of the EGS case. \\
\hline & Stimulation Cost & \$K/well & 500 & $-9.0 \%$ & $0.0 \%$ & $12.5 \%$ & $60 \%$ & Might lead to more expensive fluids and proppants \\
\hline & Production Well Flow Rate & gpm/well & 2,000 & $1.3 \%$ & $4.3 \%$ & $6.3 \%$ & $60 \%$ & Better diagnostic tools for evaluating candidates \\
\hline & Temperature Drawdown Rate & \%/year & $0.30 \%$ & & & & & \\
\hline & Annual O\&M non-labor & $\%$ & $1.5 \%$ & & & & & \\
\hline & Number of O\&M staff & $\#$ & 14.6 & & & & & \\
\hline \multirow{13}{*}{$\begin{array}{l}\text { TIO 3- Control of } \\
\text { fracturing - new and } \\
\text { improved borehole } \\
\text { packers }\end{array}$} & Utilization Factor & $\%$ & $95 \%$ & & & & & \\
\hline & Brine Effectiveness & W-h/lb & 4.63 & & & & & \\
\hline & Plant Cost & $\$ \mathrm{k} / \mathrm{kW}$ & 2,445 & & & & & \\
\hline & Production Well Cost & \$K/well & 1,222 & & & & & \\
\hline & Injector Well Cost & \$K/well & 1,222 & & & & & \\
\hline & Surface Equipment Cost & \$K/well & 100 & & & & & \\
\hline & Exploration Success & Ratio & 0.20 & & & & & \\
\hline & Confirmation Success & Ratio & 0.60 & & & & & Assumed that this EGS TIO impacts the HT case at $25 \%$ of the EGS case. \\
\hline & Stimulation Cost & \$K/well & 500 & $-6.3 \%$ & $0.0 \%$ & $6.3 \%$ & $10 \%$ & Uncertain whether there would be a reduction of materials and equipment \\
\hline & Production Well Flow Rate & gpm/well & 2,000 & $2.5 \%$ & $4.4 \%$ & $8.8 \%$ & $25 \%$ & More effective fracture placement \\
\hline & Temperature Drawdown Rate & \%/year & $0.30 \%$ & & & & & \\
\hline & Annual O\&M non-labor & $\%$ & $1.5 \%$ & & & & & \\
\hline & Number of O\&M staff & \# & 14.6 & & & & & \\
\hline \multirow{13}{*}{$\begin{array}{l}\text { TIO 4- Develop } \\
\text { numerical models } \\
\text { that accurately } \\
\text { predict fracture } \\
\text { growth and } \\
\text { permeability } \\
\text { development }\end{array}$} & \begin{tabular}{|l} 
Utilization Factor \\
\end{tabular} & $\%$ & $95 \%$ & & & & & \\
\hline & Brine Effectiveness & W-h/lb & 4.63 & & & & & \\
\hline & Plant Cost & $\$ / k W$ & 2,445 & & & & & \\
\hline & Production Well Cost & \$K/well & 1,222 & & & & & \\
\hline & Injector Well Cost & \$K/well & 1,222 & & & & & \\
\hline & Surface Equipment Cost & \$K/well & 100 & & & & & \\
\hline & Exploration Success & Ratio & 0.20 & & & & & \\
\hline & Confirmation Success & Ratio & 0.60 & & & & & Assumed that this EGS TIO impacts the HT case at $100 \%$ of the EGS case. \\
\hline & Stimulation Cost & \$K/well & 500 & $-20.0 \%$ & $10.0 \%$ & $30.0 \%$ & $10 \%$ & HHP and Materials may Increase or Decrease \\
\hline & Production Well Flow Rate & $\mathrm{gpm} / \mathrm{well}$ & 2,000 & $10.0 \%$ & $25.0 \%$ & $50.0 \%$ & $70 \%$ & More effective fracture optimization \\
\hline & Temperature Drawdown Rate & \%/year & $0.30 \%$ & $4.0 \%$ & $10.0 \%$ & $15.0 \%$ & $40 \%$ & \\
\hline & Annual O\&M non-labor & $\%$ & $1.5 \%$ & & & & & \\
\hline & Number of O\&M staff & \# & 14.6 & & & & & \\
\hline
\end{tabular}




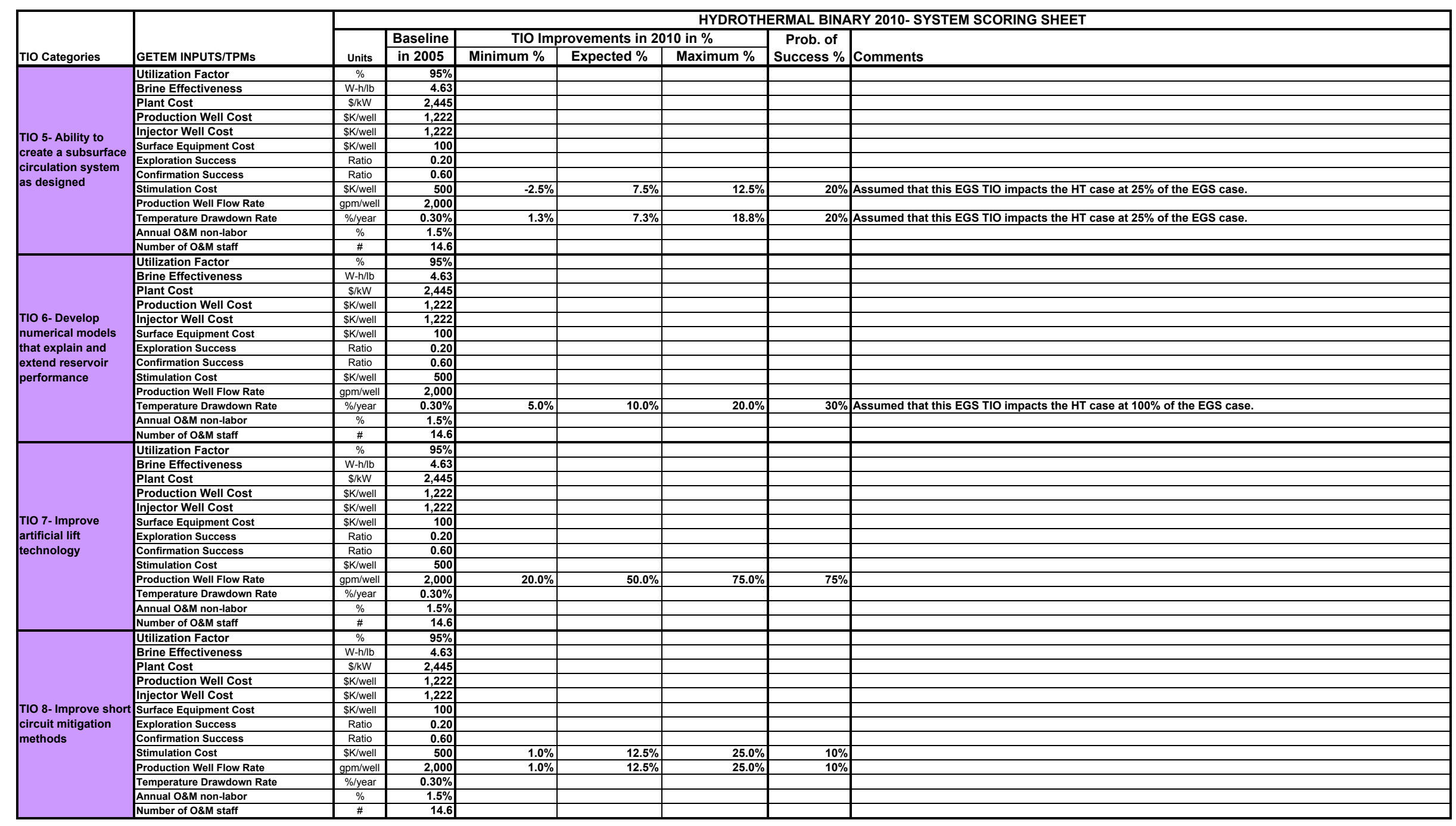




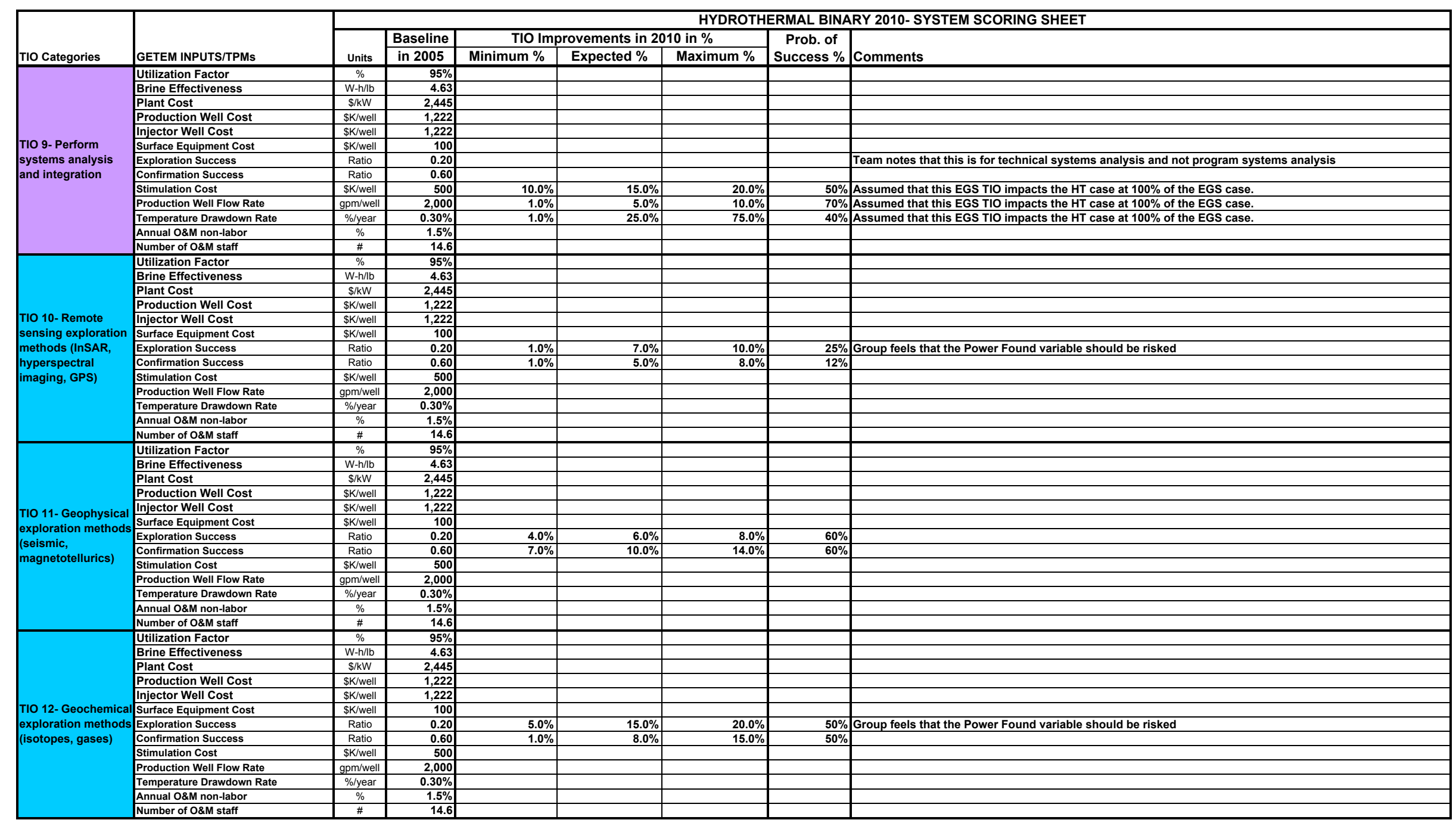




\begin{tabular}{|c|c|c|c|c|c|c|c|c|}
\hline \multirow[b]{3}{*}{ TIO Categories } & \multirow[b]{3}{*}{ GETEM INPUTS/TPMS } & \multicolumn{7}{|c|}{ HYDROTHERMAL BINARY 2010-SYSTEM SCORING SHEET } \\
\hline & & \multirow[b]{2}{*}{ Units } & \multirow{2}{*}{\begin{tabular}{|c|} 
Baseline \\
in 2005 \\
\end{tabular}} & \multicolumn{3}{|c|}{ TIO Improvements in 2010 in \% } & \multirow{2}{*}{$\begin{array}{c}\text { Prob. of } \\
\text { Success } \%\end{array}$} & \multirow[b]{2}{*}{ Comments } \\
\hline & & & & Minimum \% & Expected \% & Maximum \% & & \\
\hline \multirow{12}{*}{$\begin{array}{l}\text { TIO 13- National } \\
\text { geothermal } \\
\text { assessment and } \\
\text { supply (EGS, } \\
\text { hydrothermal) }\end{array}$} & Utilization Factor & $\%$ & $95 \%$ & & & & & \\
\hline & $\begin{array}{l}\text { Brine Effectiveness } \\
\text { Plant Cost }\end{array}$ & $\frac{W-h / b}{S(k / \mathrm{b} /}$ & $\begin{array}{r}4.63 \\
245\end{array}$ & & & & & \\
\hline & Production Well Cost & $\$$ \$K/WVell & $\frac{2,245}{1,222}$ & & & & & \\
\hline & Injector Well Cost & $\$ \mathrm{~K} / \mathrm{well}$ & 1,222 & & & & & \\
\hline & Surface Equipment Cost & \$K/well & 100 & & & & & \\
\hline & Exploration Success & Ratio & 0.20 & & & & & $\begin{array}{l}\text { Really an enabling TIO that allows the other improvements to be made. Needs to be done to support or } \\
\text { condemn the program. Industry has been pushing for this (thinking that it would be the program going out } \\
\text { and actually drilling wells). }\end{array}$ \\
\hline & Confirmation Success & Ratio & 0.60 & & & & & \\
\hline & Stimulation Cost & \$K/well & 500 & & & & & \\
\hline & \begin{tabular}{|l} 
Production Well Flow Rate \\
\end{tabular} & gpm/well & 2,000 & & & & & \\
\hline & Temperature Drawdown Rate & $\% /$ /year & $0.30 \%$ & & & & & \\
\hline & Annual O\&M non-labor & $\%$ & $1.5 \%$ & & & & & \\
\hline & Number of O\&M staff & \# & 14.6 & & & & & \\
\hline \multirow{12}{*}{$\begin{array}{l}\text { TIO 14- Reduction of } \\
\text { drilling time and } \\
\text { expense, especially } \\
\text { in hard abrasive } \\
\text { formations }\end{array}$} & 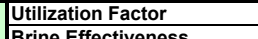 & $\%$ & $\frac{95 \%}{463}$ & & & & & \\
\hline & \begin{tabular}{|l} 
Brine Ertectiveness \\
Plant Cost
\end{tabular} & $\$ \mathrm{Wh/ \textrm {b }} / \mathrm{k}$ & 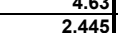 & & & & & 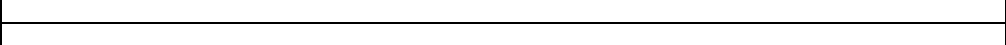 \\
\hline & Production Well Cost & $\$$ TK/well & $\frac{2,245}{1,222}$ & $5.0 \%$ & $8.0 \%$ & $12.0 \%$ & $65 \%$ & ROP improvements only. Budget too low. \\
\hline & Injector Well Cost & \$K/well & 1,222 & $5.0 \%$ & $8.0 \%$ & $12.0 \%$ & $65 \%$ & ROP improvements only. Budget too low. \\
\hline & Surface Equipment Cost & \$K/well & 100 & & & & & \\
\hline & Exploration Success & Ratio & 0.20 & & & & & \\
\hline & \begin{tabular}{|l|} 
Confirmation Success \\
\end{tabular} & Ratio & 0.60 & & & & & \\
\hline & Stimulation Cost & $\$ \mathrm{~K} / \mathrm{well}$ & 500 & & & & & \\
\hline & Production Well Flow Rate & $\mathrm{gpm} / \mathrm{well}$ & 2,000 & & & & & \\
\hline & Temperature Drawdown Rate & $\% /$ /year & $0.30 \%$ & & & & & \\
\hline & Annual O\&M non-labor & $\%$ & $1.5 \%$ & & & & & \\
\hline & Number of O\&M staff & \# & 14.6 & & & & & \\
\hline \multirow{13}{*}{$\begin{array}{l}\text { TIO 15- Reduction } \\
\text { time and expense to } \\
\text { line the wellbore } \\
\text { (including using less } \\
\text { material and less } \\
\text { costly material) }\end{array}$} & Utilization Factor & $\%$ & $95 \%$ & & & & & \\
\hline & Brine Effectiveness & $\frac{W-h / l b}{S}$ & $\begin{array}{r}4.63 \\
2.45\end{array}$ & & & & & \\
\hline & Plant Cost & & 2,445 & & & & & $\begin{array}{l}\text { Titanium could be used in the Salton Sea wells, and others, but not in all, so limiting impact to account from } \\
\end{array}$ \\
\hline & Production Well Cost & \$K/well & 1,222 & $2.0 \%$ & $6.0 \%$ & $11.0 \%$ & $50 \%$ & 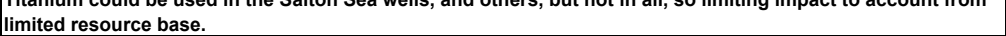 \\
\hline & Injector Well Cost & $\$ \mathrm{~K} / \mathrm{well}$ & 1,222 & $2.0 \%$ & $6.0 \%$ & $11.0 \%$ & $50 \%$ & \\
\hline & Surface Equipment Cost & \$K/well & 100 & & & & & \\
\hline & Exploration Success & Ratio & 0.20 & & & & & \\
\hline & Confirmation Success & Ratio & 0.60 & & & & & \\
\hline & Stimulation Cost & $\$ \mathrm{~K} / \mathrm{well}$ & 500 & & & & & \\
\hline & Production Well Flow Rate & $\mathrm{gpm} / \mathrm{well}$ & 2,000 & & & & & \\
\hline & Temperature Drawdown Rate & \%/year & $0.30 \%$ & & & & & \\
\hline & Annual O\&M non-labor & $\%$ & $1.5 \%$ & & & & & \\
\hline & Number of O\&M staff & \# & 14.6 & & & & & \\
\hline \multirow{13}{*}{$\begin{array}{l}\text { TIO 16- Reduction of } \\
\text { non-essential flat } \\
\text { time }\end{array}$} & Utilization Factor & $\%$ & $95 \%$ & & & & & \\
\hline & Brine Effectiveness & W-h/lb & 4.63 & & & & & \\
\hline & Plant Cost & $\$ / \mathrm{kW}$ & 2,445 & & & & & \\
\hline & Production Well Cost & \$K/well & 1,222 & $2.0 \%$ & $5.0 \%$ & $11.0 \%$ & $40 \%$ & Experts would like to see more budget and effort geared towards this TIO \\
\hline & Injector Well Cost & \$K/well & 1,222 & $2.0 \%$ & $5.0 \%$ & $11.0 \%$ & $40 \%$ & Experts would like to see more budget and effort geared towards this TIO \\
\hline & Surface Equipment Cost & $\$ \mathrm{~K} / \mathrm{well}$ & 100 & & & & & \\
\hline & Exploration Success & Ratio & 0.20 & & & & & \\
\hline & Confirmation Success & Ratio & 0.60 & & & & & \\
\hline & Stimulation Cost & \$K/well & 500 & & & & & \\
\hline & Production Well Flow Rate & $\mathrm{gpm} / \mathrm{well}$ & 2,000 & & & & & \\
\hline & Temperature Drawdown Rate & $\% /$ /year & $0.30 \%$ & & & & & \\
\hline & Annual O\&M non-labor & $\%$ & $1.5 \%$ & & & & & \\
\hline & Number of O\&M staff & & 14.6 & & & & & \\
\hline
\end{tabular}




\begin{tabular}{|c|c|c|c|c|c|c|c|c|}
\hline \multirow[b]{3}{*}{ TIO Categories } & \multirow[b]{3}{*}{ GETEM INPUTS/TPMs } & \multicolumn{7}{|c|}{ HYDROTHERMAL BINARY 2010- SYSTEM SCORING SHEET } \\
\hline & & \multirow[b]{2}{*}{ Units } & \multirow{2}{*}{$\begin{array}{c}\text { Baseline } \\
\text { in } 2005 \\
\end{array}$} & \multicolumn{3}{|c|}{ TIO Improvements in 2010 in \% } & \multirow{2}{*}{$\begin{array}{c}\text { Prob. of } \\
\text { Success \% }\end{array}$} & \multirow[b]{2}{*}{ Comments } \\
\hline & & & & Minimum \% & Expected \% & Maximum \% & & \\
\hline \multirow{12}{*}{$\begin{array}{l}\text { TIO 17- Development } \\
\text { of basic information } \\
\text { through analysis } \\
\text { and simulation } \\
\text { efforts. }\end{array}$} & \begin{tabular}{|l} 
Utilization Factor \\
\end{tabular} & $\%$ & $95 \%$ & & & & & \\
\hline & \begin{tabular}{|l} 
Brine Effectiveness \\
Plant Cost
\end{tabular} & $\begin{array}{c}\mathrm{W}-\mathrm{h} / \mathrm{b} \\
/ \mathrm{kW}\end{array}$ & 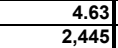 & & & & & \\
\hline & Production Well Cost & \$K/well & 1,222 & $3.0 \%$ & $7.5 \%$ & $15.0 \%$ & $80 \%$ & Electronics development will be important for advances under this TIO. \\
\hline & Injector Well Cost & \$K/well & 1,222 & $3.0 \%$ & $7.5 \%$ & $15.0 \%$ & $80 \%$ & $\begin{array}{l}\text { Only one expert considered improvements to Production Well Flow rate, but other experts thought that is } \\
\text { being handled under the EGS/Exploration TIOs. }\end{array}$ \\
\hline & Surface Equipment Cost & \$K/well & 100 & & & & & \\
\hline & Exploration Success & Ratio & 0.20 & & & & & \\
\hline & \begin{tabular}{|l} 
Confirmation Success \\
\end{tabular} & Ratio & 0.60 & & & & & \\
\hline & Stimulation Cost & \$K/well & 500 & & & & & \\
\hline & \begin{tabular}{|l} 
Production Well Flow Rate \\
\end{tabular} & gpm/well & 2,000 & & & & & \\
\hline & Temperature Drawdown Rate & \%/year & $0.30 \%$ & & & & & \\
\hline & \begin{tabular}{|l|l} 
Annual O\&M non-labor \\
\end{tabular} & $\%$ & $1.5 \%$ & & & & & \\
\hline & Number of O\&M staff & \# & 14.6 & & & & & \\
\hline \multirow{11}{*}{$\begin{array}{l}\text { TIO 18-Completion } \\
\text { and production } \\
\text { related development } \\
\text { projects }\end{array}$} & \begin{tabular}{|l} 
Utilization Factor \\
\end{tabular} & $\%$ & $95 \%$ & & & & & \\
\hline & \begin{tabular}{|l} 
Brine Effectiveness \\
Plant Cost
\end{tabular} & $\frac{W-h / b}{S / k W}$ & $\begin{array}{r}4.63 \\
2.45 \\
\end{array}$ & & & & & \\
\hline & Production Well Cost & \$K/well & 1,222 & $2.0 \%$ & $4.0 \%$ & $6.0 \%$ & $70 \%$ & According to GETEM the best we can do is 1 well equivalent. Changes wellbore configuration. \\
\hline & Injector Well Cost & \$K/well & 1,222 & $2.0 \%$ & $4.0 \%$ & $6.0 \%$ & $70 \%$ & According to GETEM the best we can do is 1 well equivalent. Changes wellbore configuration. \\
\hline & Surface Equipment Cost & \$K/well & 100 & & & & & \\
\hline & \begin{tabular}{|l} 
Exploration Success \\
\end{tabular} & Ratio & 0.20 & & & & & \\
\hline & Confirmation Success & Ratio & 0.60 & & & & & \\
\hline & \begin{tabular}{|l|l} 
Stimulation Cost \\
\end{tabular} & \$K/well & 500 & & & & & \\
\hline & \begin{tabular}{|l|} 
Production Well Flow Rate \\
Temperature Drawdown Rate
\end{tabular} & $\begin{array}{c}\text { gpm/well } \\
\% / y e a r\end{array}$ & 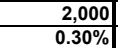 & & & & & \\
\hline & \begin{tabular}{|l|} 
Annual O\&M M non-labor \\
\end{tabular} & $\%$ & $1.5 \%$ & & & & & $\begin{array}{l}\begin{array}{l}\text { One expert thought this TIO might have a small impact on fields in terms of life cycle costs, with the exception } \\
\text { of very corrosive or very hot fields. }\end{array}\end{array}$ \\
\hline & Number of O\&M staff & \# & 14.6 & & & & & \\
\hline \multirow{13}{*}{$\begin{array}{l}\text { TIO 19-Cycle } \\
\text { Related }\end{array}$} & Utilization Factor & $\%$ & $95 \%$ & $1.0 \%$ & $3.0 \%$ & $4.0 \%$ & $90 \%$ & \\
\hline & Brine Effectiveness & W-h/lb & 4.63 & $4.6 \%$ & $10.0 \%$ & $17.4 \%$ & $80 \%$ & Experts used the average of their independent estimates to form the consensus estimate. \\
\hline & Plant Cost & $\$ / \mathrm{kW}$ & 2,445 & & & & & Experts assumed the impact would be cost-neutral. \\
\hline & Production Well Cost & \$K/well & 1,222 & & & & & \\
\hline & Injector Well Cost & \$K/well & 1,222 & & & & & \\
\hline & Surface Equipment Cost & \$K/well & 100 & & & & & \\
\hline & \begin{tabular}{|l} 
Exploration Success \\
\end{tabular} & Ratio & 0.20 & & & & & \\
\hline & Confirmation Success & Ratio & 0.60 & & & & & \\
\hline & Stimulation Cost & \$K/well & 500 & & & & & \\
\hline & Production Well Flow Rate & gpm/well & 2,000 & & & & & \\
\hline & Temperature Drawdown Rate & \%/year & $0.30 \%$ & & & & & \\
\hline & Annual O\&M non-labor & $\%$ & $1.5 \%$ & & & & & \\
\hline & Number of O\&M staff & \# & 14.6 & & & & & \\
\hline \multirow{13}{*}{$\begin{array}{l}\text { TiO 20-Component } \\
\text { Related }\end{array}$} & Utilization Factor & $\%$ & $95 \%$ & $1.0 \%$ & $3.0 \%$ & $4.0 \%$ & $80 \%$ & \\
\hline & Brine Effectiveness & W-h/lb & 4.63 & $3.3 \%$ & $8.0 \%$ & $12.5 \%$ & $75 \%$ & Experts strongly indicated that lower temperature resources need to be addressed in research. \\
\hline & Plant Cost & $\$ / k W$ & 2,445 & $2.0 \%$ & $5.0 \%$ & $7.8 \%$ & $75 \%$ & \\
\hline & Production Well Cost & \$K/well & 1,222 & & & & & \\
\hline & Injector Well Cost & \$K/well & 1,222 & & & & & \\
\hline & Surface Equipment Cost & \$K/well & 100 & & & & & \\
\hline & \begin{tabular}{|l|l} 
Exploration Success \\
\end{tabular} & Ratio & 0.20 & & & & & \\
\hline & \begin{tabular}{|l} 
Confirmation Success \\
Stimuth
\end{tabular} & Ratio & 0.60 & & & & & \\
\hline & Stimulation Cost & \$K/well & 500 & & & & & \\
\hline & Production Well Flow Rate & gpm/well & 2,000 & & & & & \\
\hline & \begin{tabular}{|l} 
Temperature Drawdown Rate \\
\end{tabular} & \%/year & $0.30 \%$ & & & & & \\
\hline & Annual 0\&M non-labor & $\%$ & $1.5 \%$ & $0.0 \%$ & $5.0 \%$ & $8.0 \%$ & $50 \%$ & \\
\hline & Number of O\&M staff & \# & 14.6 & & & & & Experts assumed the impact would be cost-neutral. \\
\hline
\end{tabular}




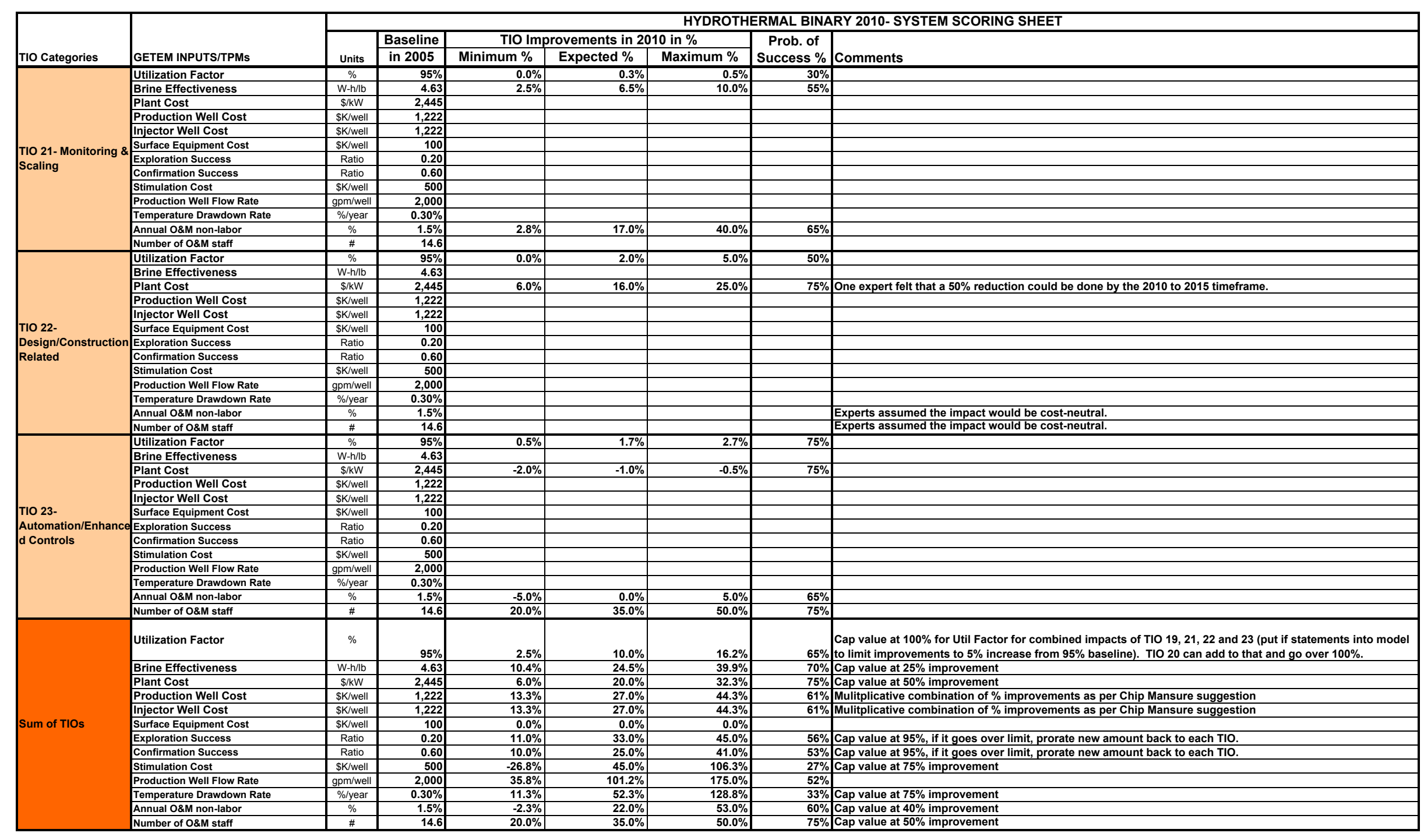




\begin{tabular}{|c|c|c|c|c|c|c|c|c|}
\hline \multirow[b]{3}{*}{ TIO Categories } & \multirow[b]{3}{*}{ GETEM INPUTS/TPMs } & \multicolumn{7}{|c|}{ HYDROTHERMAL FLASH 2010- SYSTEM SCORING SHEET } \\
\hline & & \multirow[b]{2}{*}{ Units } & \multirow{2}{*}{\begin{tabular}{|c|} 
Baseline \\
in 2005 \\
\end{tabular}} & \multicolumn{3}{|c|}{ TIO Improvements in 2010 in \% } & \multirow{2}{*}{$\begin{array}{c}\text { Prob. of } \\
\text { Success \% }\end{array}$} & \multirow[b]{2}{*}{ Comments } \\
\hline & & & & Minimum \% & Expected \% & Maximum \% & & \\
\hline \multirow{13}{*}{$\begin{array}{l}\text { TIO 1- Increase } \\
\text { accuracy of target } \\
\text { temperature } \\
\text { prediction }\end{array}$} & Utilization Factor & $\%$ & & & & & & \\
\hline & Brine Effectiveness & W-h/lb & 9.40 & & & & & \\
\hline & Plant Cost & $\$ / k W$ & 995 & & & & & \\
\hline & Production Well Cost & \$K/well & 1,910 & & & & & \\
\hline & Injector Well Cost & \$K/well & 1,910 & & & & & \\
\hline & Surface Equipment Cost & \$K/well & 100 & & & & & \\
\hline & Exploration Success & Ratio & 0.20 & $1.0 \%$ & $5.0 \%$ & $7.0 \%$ & $90 \%$ & Assumed that this EGS TIO impacts the HT case at $100 \%$ of the EGS case. \\
\hline & Confirmation Success & Ratio & 0.60 & $1.0 \%$ & $2.0 \%$ & $4.0 \%$ & $90 \%$ & Assumed that this EGS TIO impacts the HT case at $100 \%$ of the EGS case. \\
\hline & Stimulation Cost & \$K/well & 300 & & & & & \\
\hline & Production Well Flow Rate & gpm/well & 900 & & & & & \\
\hline & Temperature Drawdown Rate & \%/year & $2.00 \%$ & & & & & \\
\hline & Annual O\&M non-labor & $\%$ & $1.5 \%$ & & & & & \\
\hline & Number of O\&M staff & \# & 16.3 & & & & & \\
\hline \multirow{13}{*}{$\begin{array}{l}\text { TIO 2-Improve } \\
\text { fracture methods, } \\
\text { proppants and } \\
\text { rheology }\end{array}$} & Utilization Factor & $\%$ & $90 \%$ & & & & & \\
\hline & Brine Effectiveness & W-hllb & 9.40 & & & & & \\
\hline & Plant Cost & $\$(k \mathrm{~kW}$ & 995 & & & & & \\
\hline & Production Well Cost & \$K/well & 1,910 & & & & & \\
\hline & Injector Well Cost & \$K/well & 1,910 & & & & & \\
\hline & Surface Equipment Cost & \$K/well & 100 & & & & & \\
\hline & Exploration Success & Ratio & 0.20 & & & & & \\
\hline & Confirmation Success & Ratio & 0.60 & & & & & Assumed that this EGS TIO impacts the HT case at $25 \%$ of the EGS case. \\
\hline & Stimulation Cost & \$K/well & 300 & $-8.8 \%$ & $0.0 \%$ & $12.5 \%$ & $60 \%$ & Might lead to more expensive fluids and proppants \\
\hline & \begin{tabular}{|l|l} 
Production Well Flow Rate \\
\end{tabular} & $\mathrm{gpm} / \mathrm{well}$ & 900 & $1.3 \%$ & $3.3 \%$ & $6.3 \%$ & $60 \%$ & Better diagnostic tools for evaluating candidates \\
\hline & Temperature Drawdown Rate & \%/year & $2.00 \%$ & & & & & \\
\hline & Annual O\&M non-labor & $\%$ & $1.5 \%$ & & & & & \\
\hline & Number of O\&M staff & \# & 16.3 & & & & & \\
\hline \multirow{13}{*}{$\begin{array}{l}\text { TIO 3-Control of } \\
\text { fracturing - new and } \\
\text { improved borehole } \\
\text { packers }\end{array}$} & Utilization Factor & $\%$ & $90 \%$ & & & & & \\
\hline & Brine Effectiveness & W-hlib & 9.40 & & & & & \\
\hline & Plant Cost & $\$ / k W$ & 995 & & & & & \\
\hline & Production Well Cost & \$K/well & 1,910 & & & & & \\
\hline & Injector Well Cost & \$K/well & 1,910 & & & & & \\
\hline & Surface Equipment Cost & \$K/well & 100 & & & & & \\
\hline & Exploration Success & Ratio & 0.20 & & & & & \\
\hline & Confirmation Success & Ratio & 0.60 & & & & & Assumed that this EGS TIO impacts the HT case at $25 \%$ of the EGS case. \\
\hline & Stimulation Cost & \$K/well & 300 & $-6.3 \%$ & $0.0 \%$ & $6.3 \%$ & $10 \%$ & Uncertain whether there would be a reduction of materials and equipment \\
\hline & Production Well Flow Rate & $\mathrm{gpm} / \mathrm{well}$ & 900 & $2.5 \%$ & $4.4 \%$ & $8.8 \%$ & $25 \%$ & More effective fracture placement \\
\hline & Temperature Drawdown Rate & \%/year & $2.00 \%$ & & & & & \\
\hline & Annual O\&M non-labor & $\%$ & $1.5 \%$ & & & & & \\
\hline & Number of O\&M staff & \# & 16.3 & & & & & \\
\hline \multirow{13}{*}{$\begin{array}{l}\text { TIO 4- Develop } \\
\text { numerical models } \\
\text { that accurately } \\
\text { predict fracture } \\
\text { growth and } \\
\text { permeability } \\
\text { development }\end{array}$} & Utilization Factor & $\%$ & $90 \%$ & & & & & \\
\hline & Brine Effectiveness & W-h/lb & 9.40 & & & & & \\
\hline & \begin{tabular}{|l|l} 
Plant Cost \\
Pliness
\end{tabular} & S $/ \mathrm{kW}$ & 9.495 & & & & & \\
\hline & Production Well Cost & 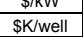 & $\begin{array}{r}9,910 \\
1,10\end{array}$ & & & & & \\
\hline & $\begin{array}{l}\text { Injector Well Cost } \\
\text { Injt }\end{array}$ & $\begin{array}{l}\text { Sk/weil } \\
\text { \$K/Well } \\
\end{array}$ & $\frac{1,910}{1,910}$ & & & & & \\
\hline & Surface Equipment Cost & \$K/well & 100 & & & & & \\
\hline & Exploration Success & Ratio & 0.20 & & & & & \\
\hline & Confirmation Success & Ratio & 0.60 & & & & & Assumed that this EGS TIO impacts the HT case at $100 \%$ of the EGS case. \\
\hline & Stimulation Cost & \$K/well & 300 & $-20.0 \%$ & $10.0 \%$ & $30.0 \%$ & $10 \%$ & HHP and Materials may Increase or Decrease \\
\hline & Production Well Flow Rate & gpm/well & 900 & $10.0 \%$ & $25.0 \%$ & $50.0 \%$ & $70 \%$ & More effective fracture optimization \\
\hline & Temperature Drawdown Rate & \%/year & $2.00 \%$ & $4.0 \%$ & $10.0 \%$ & $15.0 \%$ & $40 \%$ & \\
\hline & Annual O\&M non-labor & $\%$ & $1.5 \%$ & & & & & \\
\hline & Number of O\&M staff & \# & 16.3 & & & & & \\
\hline
\end{tabular}




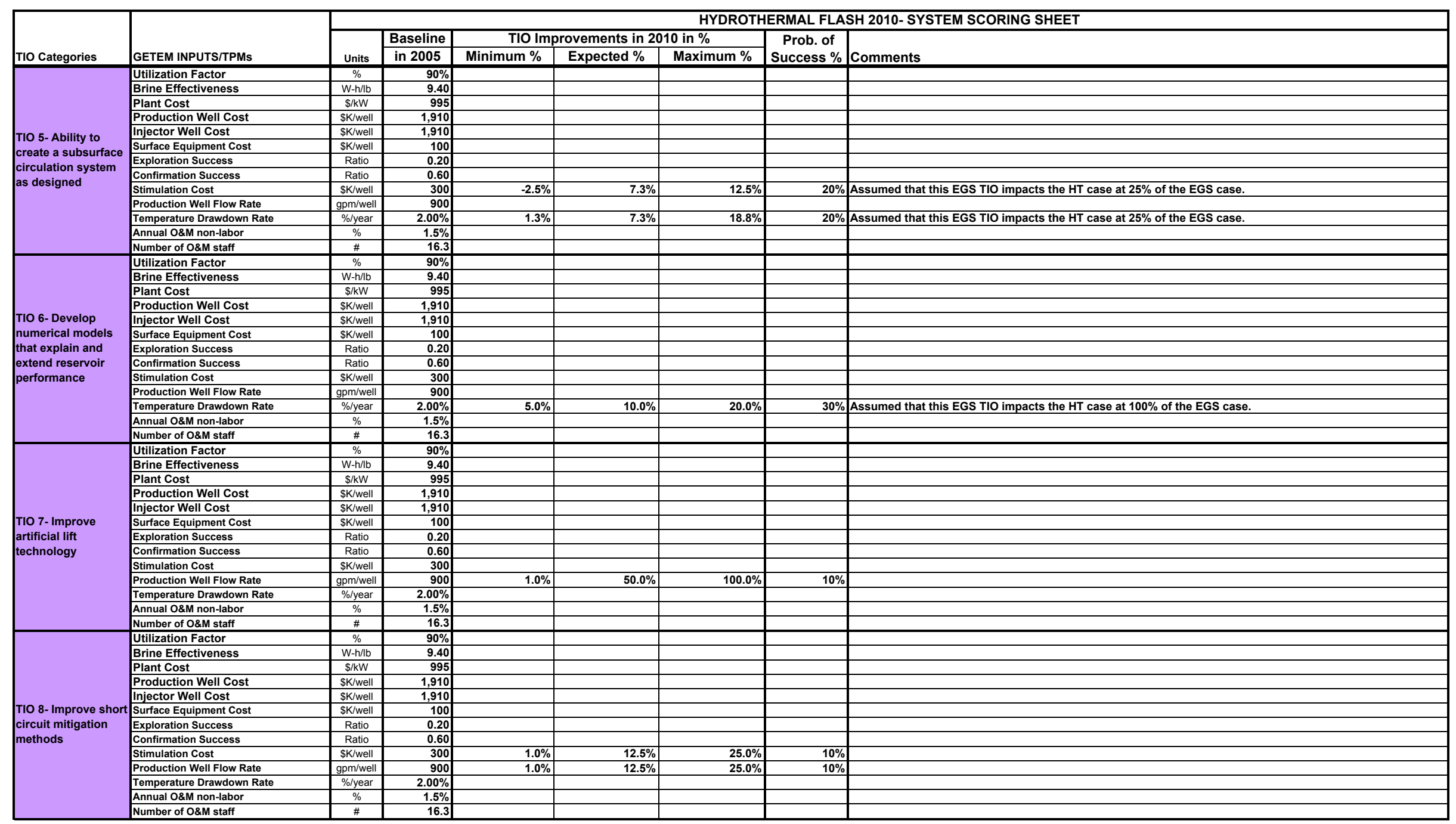




\begin{tabular}{|c|c|c|c|c|c|c|c|c|}
\hline \multirow[b]{3}{*}{ TIO Categories } & \multirow[b]{3}{*}{ GETEM INPUTS/TPMs } & \multicolumn{7}{|c|}{ HYDROTHERMAL FLASH 2010- SYSTEM SCORING SHEET } \\
\hline & & \multirow[b]{2}{*}{ Units } & \multirow{2}{*}{\begin{tabular}{|c|} 
Baseline \\
in 2005 \\
\end{tabular}} & \multicolumn{3}{|c|}{ TIO Improvements in 2010 in \% } & \multirow{2}{*}{\begin{tabular}{|c|} 
Prob. of \\
Success \%
\end{tabular}} & \multirow[b]{2}{*}{ Comments } \\
\hline & & & & Minimum \% & Expected \% & Maximum \% & & \\
\hline \multirow{13}{*}{$\begin{array}{l}\text { TIO 9-Perform } \\
\text { systems analysis } \\
\text { and integration }\end{array}$} & Utilization Factor & $\%$ & & & & & & \\
\hline & \begin{tabular}{|l|l|l} 
Brine Effectiveness \\
\end{tabular} & W-h/lb & 9.40 & & & & & \\
\hline & \begin{tabular}{|l} 
Prine Erieciveness \\
Plant Cost
\end{tabular} & $\$ \mathrm{~W} / \mathrm{kW}$ & 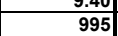 & & & & & \\
\hline & Production Well Cost & \$K/well & 1,910 & & & & & \\
\hline & Injector Well Cost & \$K/well & 1,910 & & & & & \\
\hline & Surface Equipment Cost & \$K/well & 100 & & & & & \\
\hline & Exploration Success & Ratio & 0.20 & & & & & Team notes that this is for technical systems analysis and not program systems analysis \\
\hline & Confirmation Success & Ratio & 0.60 & & & & & \\
\hline & Stimulation Cost & \$K/well & 300 & $10.0 \%$ & $15.0 \%$ & $20.0 \%$ & $50 \%$ & Assumed that this EGS TIO impacts the HT case at $100 \%$ of the EGS case. \\
\hline & Production Well Flow Rate & $\mathrm{gpm} / \mathrm{well}$ & 900 & $1.0 \%$ & $5.0 \%$ & $10.0 \%$ & $70 \%$ & Assumed that this EGS TIO impacts the HT case at $100 \%$ of the EGS case. \\
\hline & Temperature Drawdown Rate & \%/year & $2.00 \%$ & $1.0 \%$ & $25.0 \%$ & $75.0 \%$ & $40 \%$ & Assumed that this EGS TIO impacts the HT case at $100 \%$ of the EGS case. \\
\hline & Annual O\&M non-labor & $\%$ & $1.5 \%$ & & & & & \\
\hline & Number of O\&M staff & \# & 16.3 & & & & & \\
\hline \multirow{13}{*}{$\begin{array}{l}\text { TIO 10- Remote } \\
\text { sensing exploration } \\
\text { methods (InSAR, } \\
\text { hyperspectral } \\
\text { imaging, GPS) }\end{array}$} & Utilization Factor & $\%$ & $90 \%$ & & & & & \\
\hline & Brine Effectiveness & W-hlib & 9.40 & & & & & \\
\hline & 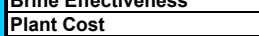 & 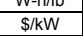 & 9.495 & & & & & \\
\hline & \begin{tabular}{|l} 
Production Well Cost \\
Prodion
\end{tabular} & $\$$ SK/WVIII & $\frac{990}{1,910}$ & & & & & \\
\hline & \begin{tabular}{|l} 
rodouction Wvell ost \\
Injector Well Cost \\
\end{tabular} & 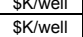 & $\frac{1,1910}{1,910}$ & & & & & \\
\hline & Surface Equipment Cost & \$K/well & 100 & & & & & \\
\hline & Exploration Success & Ratio & 0.20 & $1.0 \%$ & $7.0 \%$ & $10.0 \%$ & $25 \%$ & Group feels that the Power Found variable should be risked \\
\hline & Confirmation Success & Ratio & 0.60 & $1.0 \%$ & $5.0 \%$ & $8.0 \%$ & $12 \%$ & \\
\hline & Stimulation Cost & \$K/well & 300 & & & & & \\
\hline & Production Well Flow Rate & gpm/well & 900 & & & & & \\
\hline & Temperature Drawdown Rate & \%/year & $2.00 \%$ & & & & & \\
\hline & Annual O\&M non-labor & $\%$ & $1.5 \%$ & & & & & \\
\hline & Number of O\&M staff & \# & 16.3 & & & & & \\
\hline \multirow{13}{*}{$\begin{array}{l}\text { TIO 11- Geophysical } \\
\text { exploration methods } \\
\text { (seismic, } \\
\text { magnetotellurics) }\end{array}$} & Utilization Factor & $\%$ & $90 \%$ & & & & & \\
\hline & \begin{tabular}{|l} 
Brine Effectiveness \\
\end{tabular} & $\frac{10}{W-h / l b}$ & 9.40 & & & & & \\
\hline & \begin{tabular}{|l} 
Drine Enecilveness \\
Plant Cost
\end{tabular} & $\frac{\mathrm{W}-\mathrm{n} / \mathrm{i}}{\mathrm{S} \mathrm{kW}}$ & $\begin{array}{l}3.405 \\
995 \\
\end{array}$ & & & & & \\
\hline & Production Well Cost & \$K/well & 1,910 & & & & & \\
\hline & Injector Well Cost & \$K/well & 1,910 & & & & & \\
\hline & Surface Equipment Cost & \$K/well & 100 & & & & & \\
\hline & \begin{tabular}{|l} 
Exploration Success \\
\end{tabular} & Ratio & 0.20 & $4.0 \%$ & $6.0 \%$ & $8.0 \%$ & $60 \%$ & \\
\hline & \begin{tabular}{|l|} 
Confirmation Success \\
\end{tabular} & Ratio & 0.60 & $7.0 \%$ & $10.0 \%$ & $14.0 \%$ & $60 \%$ & \\
\hline & \begin{tabular}{|l} 
Stimulation Cost \\
\end{tabular} & \$K/well & 300 & & & & & \\
\hline & Production Well Flow Rate & $\mathrm{gpm} / \mathrm{well}$ & 900 & & & & & \\
\hline & Temperature Drawdown Rate & \%/year & $2.00 \%$ & & & & & \\
\hline & Annual O\&M non-labor & $\%$ & $1.5 \%$ & & & & & \\
\hline & Number of O\&M staff & $\#$ & 16.3 & & & & & \\
\hline \multirow{13}{*}{$\begin{array}{l}\text { TIO 12- Geochemica } \\
\text { exploration methods } \\
\text { (isotopes, gases) }\end{array}$} & Utilization Factor & $\%$ & $90 \%$ & & & & & \\
\hline & Brine Effectiveness & W-h/lb & 9.40 & & & & & \\
\hline & \begin{tabular}{|l} 
Plant Cost \\
\end{tabular} & $\$ / k W$ & 995 & & & & & \\
\hline & Production Well Cost & \$K/well & 1,910 & & & & & \\
\hline & \begin{tabular}{|l} 
Injector Well Cost \\
Injt
\end{tabular} & $\begin{array}{l}\text { Sh/weil } \\
\text { \$K/well } \\
\end{array}$ & $\frac{1,910}{1,910}$ & & & & & \\
\hline & Surface Equipment Cost & \$K/well & 100 & & & & & \\
\hline & Exploration Success & Ratio & 0.20 & $5.0 \%$ & $15.0 \%$ & $20.0 \%$ & $50 \%$ & Group feels that the Power Found variable should be risked \\
\hline & Confirmation Success & Ratio & 0.60 & $1.0 \%$ & $8.0 \%$ & $15.0 \%$ & $50 \%$ & \\
\hline & Stimulation Cost & \$K/well & 300 & & & & & \\
\hline & \begin{tabular}{|l} 
Production Well Flow Rate \\
\end{tabular} & $\mathrm{gpm} / \mathrm{well}$ & 900 & & & & & \\
\hline & Temperature Drawdown Rate & \%/year & $2.00 \%$ & & & & & \\
\hline & Annual O\&M non-labor & $\%$ & $1.5 \%$ & & & & & \\
\hline & Number of O\&M staff & \# & 16.3 & & & & & \\
\hline
\end{tabular}




\begin{tabular}{|c|c|c|c|c|c|c|c|c|}
\hline \multirow[b]{3}{*}{ TIO Categories } & \multirow[b]{3}{*}{ GETEM INPUTS/TPMS } & \multicolumn{7}{|c|}{ HYDROTHERMAL FLASH 2010-SYSTEM SCORING SHEET } \\
\hline & & \multirow[b]{2}{*}{ Units } & \multirow{2}{*}{$\begin{array}{l}\text { Baseline } \\
\text { in } 2005\end{array}$} & \multicolumn{3}{|c|}{ TIO Improvements in 2010 in \% } & \multirow{2}{*}{$\begin{array}{c}\text { Prob. of } \\
\text { Success \% }\end{array}$} & \multirow[b]{2}{*}{ Comments } \\
\hline & & & & Minimum \% & Expected \% & Maximum \% & & \\
\hline \multirow{12}{*}{$\begin{array}{l}\text { TIO 13- National } \\
\text { geothermal } \\
\text { assessment and } \\
\text { supply (EGS, } \\
\text { hydrothermal) }\end{array}$} & \begin{tabular}{|l} 
Utilization Factor \\
tilatis
\end{tabular} & $\%$ & $90 \%$ & & & & & \\
\hline & \begin{tabular}{|l|} 
Brine Effectiveness \\
Plant Cost
\end{tabular} & 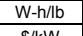 & 9.40 & & & & & \\
\hline & \begin{tabular}{|l|} 
Plant Cost \\
Production Well Cost
\end{tabular} & $\begin{array}{c}\$ / K W \\
\$ K / W e l l \\
\end{array}$ & $\begin{array}{r}995 \\
1910\end{array}$ & & & & & \\
\hline & Injector Well Cost & \$K/well & 1,910 & & & & & \\
\hline & Surface Equipment Cost & \$K/well & 100 & & & & & \\
\hline & Exploration Success & Ratio & 0.20 & & & & & $\begin{array}{l}\text { Really an enabling TIO that allows the other improvements to be made. Needs to be done to support or } \\
\text { condemn the program. Industry has been pushing for this (thinking that it would be the program going out } \\
\text { and actually drilling wells). }\end{array}$ \\
\hline & Confirmation Success & Ratio & 0.60 & & & & & \\
\hline & \begin{tabular}{|l|l} 
Stimulation Cost \\
\end{tabular} & \$K/well & 300 & & & & & \\
\hline & \begin{tabular}{|l|} 
Production Well Flow Rate \\
\end{tabular} & $\mathrm{gpm} / \mathrm{well}$ & 900 & & & & & \\
\hline & Temperature Drawdown Rate & \%/year & $2.00 \%$ & & & & & \\
\hline & Annual O\&M non-labor & $\%$ & $1.5 \%$ & & & & & \\
\hline & Number of O\&M staff & \# & 16.3 & & & & & \\
\hline \multirow{12}{*}{$\begin{array}{l}\text { TIO 14- Reduction of } \\
\text { drilling time and } \\
\text { expense, especially } \\
\text { in hard abrasive } \\
\text { formations }\end{array}$} & Utilization Factor & $\%$ & $90 \%$ & & & & & \\
\hline & \begin{tabular}{|l} 
Brine Effectiveness \\
\end{tabular} & W-h/lb & 9.40 & & & & & \\
\hline & \begin{tabular}{|l|l} 
Plant Cost \\
Production Well Cost
\end{tabular} & $\$ / k W$ & 995 & $5.0 \%$ & $8.0 \%$ & $12.0 \%$ & $65 \%$ & Experts assumed this TlO would impact the HT Flash case the same as the HT Binary case \\
\hline & $f$ Production Well Cost & $\begin{array}{l}\$ K / \text { Kell } \\
\text { \$K/Well } \\
\end{array}$ & $\frac{1,910}{1,910}$ & $5.0 \%$ & $8.0 \%$ & $12.0 \%$ & $65 \%$ & 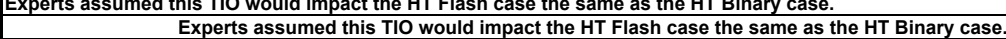 \\
\hline & Surface Equipment Cost & \$K/well & 100 & & & & & \\
\hline & Exploration Success & Ratio & 0.20 & & & & & \\
\hline & Confirmation Success & Ratio & 0.60 & & & & & \\
\hline & Stimulation Cost & \$K/well & 300 & & & & & \\
\hline & Production Well Flow Rate & $\mathrm{gpm} / \mathrm{well}$ & 900 & & & & & \\
\hline & Temperature Drawdown Rate & \%/year & $2.00 \%$ & & & & & \\
\hline & Annual O\&M non-labor & $\%$ & $1.5 \%$ & & & & & \\
\hline & Number of O\&M staff & \# & 16.3 & & & & & \\
\hline \multirow{12}{*}{$\begin{array}{l}\text { TIO 15- Reduction } \\
\text { time and expense to } \\
\text { line the wellbore } \\
\text { (including using les } \\
\text { material and less } \\
\text { costly material) }\end{array}$} & \begin{tabular}{|l} 
Utilization Factor \\
\end{tabular} & $\%$ & $90 \%$ & & & & & \\
\hline & \begin{tabular}{|l|} 
Brine Effectiveness \\
Plant Cost
\end{tabular} & \begin{tabular}{|l|}
$W-h / l b$ \\
$S / k W$ \\
\end{tabular} & \begin{tabular}{r|}
9.40 \\
995 \\
\end{tabular} & & & & & \\
\hline & Production Well Cost & $\$ K /$ well & 1,910 & $2.0 \%$ & $6.0 \%$ & $11.0 \%$ & $50 \%$ & Experts assumed this TIO would impact the HT Flash case the same as the HT Binary case. \\
\hline & Injector Well Cost & \$K/well & 1,910 & $2.0 \%$ & $6.0 \%$ & $11.0 \%$ & $50 \%$ & Experts assumed this TIO would impact the HT Flash case the same as the HT Binary case. \\
\hline & Surface Equipment Cost & \$K/well & 100 & & & & & \\
\hline & Exploration Success & Ratio & 0.20 & & & & & \\
\hline & Confirmation Success & Ratio & 0.60 & & & & & \\
\hline & Stimulation Cost & \$K/well & 300 & & & & & \\
\hline & Production Well Flow Rate & gpm/well & 900 & & & & & \\
\hline & Temperature Drawdown Rate & \%/year & $2.00 \%$ & & & & & \\
\hline & Annual O\&M non-labor & $\%$ & $1.5 \%$ & & & & & \\
\hline & Number of O\&M staff & \# & 16.3 & & & & & \\
\hline \multirow{13}{*}{$\begin{array}{l}\text { TIO 16- Reduction of } \\
\text { non-essential flat } \\
\text { time }\end{array}$} & Utilization Factor & $\%$ & & & & & & \\
\hline & \begin{tabular}{|l|l} 
Brine Effectiveness \\
\end{tabular} & W-h/lb & 9.40 & & & & & \\
\hline & Plant Cost & $\$ / \mathrm{kW}$ & 995 & & & & & \\
\hline & Production Well Cost & \$K/well & 1,910 & $2.0 \%$ & $5.0 \%$ & $11.0 \%$ & $40 \%$ & Experts assumed this TIO would impact the HT Flash case the same as the HT Binary case. \\
\hline & Injector Well Cost & \$K/well & 1,910 & $2.0 \%$ & $5.0 \%$ & $11.0 \%$ & $40 \%$ & $\begin{array}{l}\text { Experts assumed this TIO would impact the HT Flash case the same as the HT Binary case. } \\
\text {. }\end{array}$ \\
\hline & furface Equipment Cost & \$K/well & 100 & & & & & \\
\hline & Exploration Success & Ratio & 0.20 & & & & & \\
\hline & Confirmation Success & Ratio & 0.60 & & & & & \\
\hline & Stimulation Cost & \$K/well & 300 & & & & & \\
\hline & Production Well Flow Rate & gpm/well & 900 & & & & & \\
\hline & Temperature Drawdown Rate & \%/year & $2.00 \%$ & & & & & \\
\hline & Annual O\&M non-labor & $\%$ & $1.5 \%$ & & & & & \\
\hline & Number of O\&M staff & \# & 16.3 & & & & & \\
\hline
\end{tabular}




\begin{tabular}{|c|c|c|c|c|c|c|c|c|}
\hline \multirow[b]{3}{*}{ TIO Categories } & \multirow[b]{3}{*}{ GETEM INPUTS/TPMs } & \multicolumn{7}{|c|}{ HYDROTHERMAL FLASH 2010- SYSTEM SCORING SHEET } \\
\hline & & \multirow[b]{2}{*}{ Units } & \multirow{2}{*}{\begin{tabular}{|c|} 
Baseline \\
in 2005 \\
\end{tabular}} & \multicolumn{3}{|c|}{ TIO Improvements in 2010 in \% } & \multirow{2}{*}{\begin{tabular}{|c|} 
Prob. of \\
Success \%
\end{tabular}} & \multirow[b]{2}{*}{ Comments } \\
\hline & & & & Minimum \% & Expected \% & Maximum \% & & \\
\hline \multirow{12}{*}{$\begin{array}{l}\text { TIO 17- Developmen } \\
\text { of basic information } \\
\text { through analysis } \\
\text { and simulation } \\
\text { efforts. }\end{array}$} & \begin{tabular}{|l} 
Utilization Factor \\
Tilats
\end{tabular} & $\%$ & $90 \%$ & & & & & \\
\hline & \begin{tabular}{|l} 
Brine Effectiveness \\
Plant Cost
\end{tabular} & $\frac{W-h / l b}{S / k w}$ & \begin{tabular}{r|c|c|}
9.40 \\
995
\end{tabular} & & & & & \\
\hline & Production Well Cost & \$K/well & 1,910 & $3.0 \%$ & $7.5 \%$ & $15.0 \%$ & $80 \%$ & Experts assumed this TIO would impact the HT Flash case the same as the HT Binary case. \\
\hline & Injector Well Cost & \$K/well & 1,910 & $3.0 \%$ & $7.5 \%$ & $15.0 \%$ & $80 \%$ & Experts assumed this TIO would impact the HT Flash case the same as the HT Binary case. \\
\hline & Surface Equipment Cost & \$K/well & 100 & & & & & \\
\hline & Exploration Success & Ratio & 0.20 & & & & & \\
\hline & Confirmation Success & Ratio & 0.60 & & & & & \\
\hline & \begin{tabular}{|l|l} 
Stimulation Cost \\
\end{tabular} & \$K/well & 300 & & & & & \\
\hline & \begin{tabular}{|l|} 
Production Well Flow Rate \\
\end{tabular} & gpm/well & 900 & & & & & \\
\hline & Temperature Drawdown Rate & $\%$ \%year & $2.00 \%$ & & & & & \\
\hline & \begin{tabular}{|l} 
Annual O\&M non-labor \\
\end{tabular} & $\%$ & $1.5 \%$ & & & & & \\
\hline & Number of O\&M staff & \# & 1.36 .3 & & & & & \\
\hline \multirow{12}{*}{$\begin{array}{l}\text { TiO 18- Completion } \\
\text { and production } \\
\text { related development } \\
\text { projects }\end{array}$} & Utilization Factor & $\%$ & $90 \%$ & & & & & \\
\hline & Brine Effectiveness & 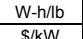 & 9.40 & & & & & \\
\hline & Production Well Cost & \$K/well & 1,910 & $2.0 \%$ & $4.0 \%$ & $6.0 \%$ & $70 \%$ & Experts assumed this TIO would impact the HT Flash case the same as the HT Binary case. \\
\hline & Injector Well Cost & \$K/well & 1,910 & $2.0 \%$ & $4.0 \%$ & $6.0 \%$ & $70 \%$ & Experts assumed this TIO would impact the HT Flash case the same as the HT Binary case. \\
\hline & Surface Equipment Cost & \$K/well & 100 & & & & & \\
\hline & Exploration Success & Ratio & 0.20 & & & & & \\
\hline & Confirmation Success & Ratio & 0.60 & & & & & \\
\hline & Stimulation Cost & \$K/well & 300 & & & & & \\
\hline & Production Well Flow Rate & $\mathrm{gpm} / \mathrm{well}$ & 900 & & & & & \\
\hline & Temperature Drawdown Rate & \%/year & $2.00 \%$ & & & & & \\
\hline & Annual O\&M non-labor & $\%$ & $1.5 \%$ & & & & & $\begin{array}{l}\text { One expert thought this TIO might have a small impact on fields in terms of life cycle costs, with the exception } \\
\text { of very corrosive or very hot fields. }\end{array}$ \\
\hline & Number of O\&M staff & $\#$ & 16.3 & & & & & \\
\hline \multirow{13}{*}{$\begin{array}{l}\text { TIO 19-Cycle } \\
\text { Related }\end{array}$} & Utilization Factor & $\%$ & $90 \%$ & $1.0 \%$ & $3.0 \%$ & $4.0 \%$ & $90 \%$ & \\
\hline & \begin{tabular}{|l|} 
Brine Effectiveness \\
\end{tabular} & W-h/lb & 9.40 & $1.0 \%$ & $5.0 \%$ & $10.0 \%$ & $90 \%$ & \\
\hline & \begin{tabular}{|l} 
Plant Cost \\
\end{tabular} & $\$ / k W$ & 995 & & & & & \\
\hline & Production Well Cost & \$K/well & 1,910 & & & & & \\
\hline & Injector Well Cost & \$K/well & 1,910 & & & & & \\
\hline & Surface Equipment Cost & \$K/well & 100 & & & & & \\
\hline & \begin{tabular}{|l} 
Exploration Success \\
\end{tabular} & Ratio & 0.20 & & & & & \\
\hline & Confirmation Success & Ratio & 0.60 & & & & & \\
\hline & Stimulation Cost & \$K/well & 300 & & & & & \\
\hline & Production Well Flow Rate & $\mathrm{gpm} / \mathrm{well}$ & 900 & & & & & \\
\hline & Temperature Drawdown Rate & \%/year & $2.00 \%$ & & & & & \\
\hline & Annual O\&M non-labor & $\%$ & $1.5 \%$ & & & & & \\
\hline & Number of O\&M staff & $\#$ & 16.3 & & & & & \\
\hline \multirow{13}{*}{$\begin{array}{l}\text { TIO 20-Component } \\
\text { Related }\end{array}$} & Utilization Factor & $\%$ & $90 \%$ & $1.0 \%$ & $3.0 \%$ & $5.0 \%$ & $80 \%$ & \\
\hline & Brine Effectiveness & W-h/lb & 9.40 & $2.3 \%$ & $6.7 \%$ & $10.0 \%$ & $70 \%$ & include comments on lower temp resources needing to be addressed \\
\hline & Plant Cost & $\$ / k W$ & 995 & & & & & \\
\hline & Production Well Cost & \$K/Well & 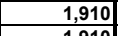 & & & & & \\
\hline & Injector Well Cost & \$K/well & 1,910 & & & & & \\
\hline & Surface Equipment Cost & \$K/well & 100 & & & & & \\
\hline & \begin{tabular}{|l} 
Exploration Success \\
\end{tabular} & Ratio & 0.20 & & & & & \\
\hline & \begin{tabular}{|l} 
Confirmation Success \\
\end{tabular} & Ratio & 0.60 & & & & & \\
\hline & \begin{tabular}{|l|l} 
Stimulation Cost \\
\end{tabular} & \$K/well & 300 & & & & & \\
\hline & \begin{tabular}{|l|} 
Production Well Flow Rate \\
\end{tabular} & $\mathrm{gpm} / \mathrm{well}$ & 900 & & & & & \\
\hline & Temperature Drawdown Rate & \%/year & $2.00 \%$ & & & & & \\
\hline & Annual O\&M non-labor & $\%$ & $1.5 \%$ & & & & & \\
\hline & Number of O\&M staff & \# & 16.3 & & & & & \\
\hline
\end{tabular}




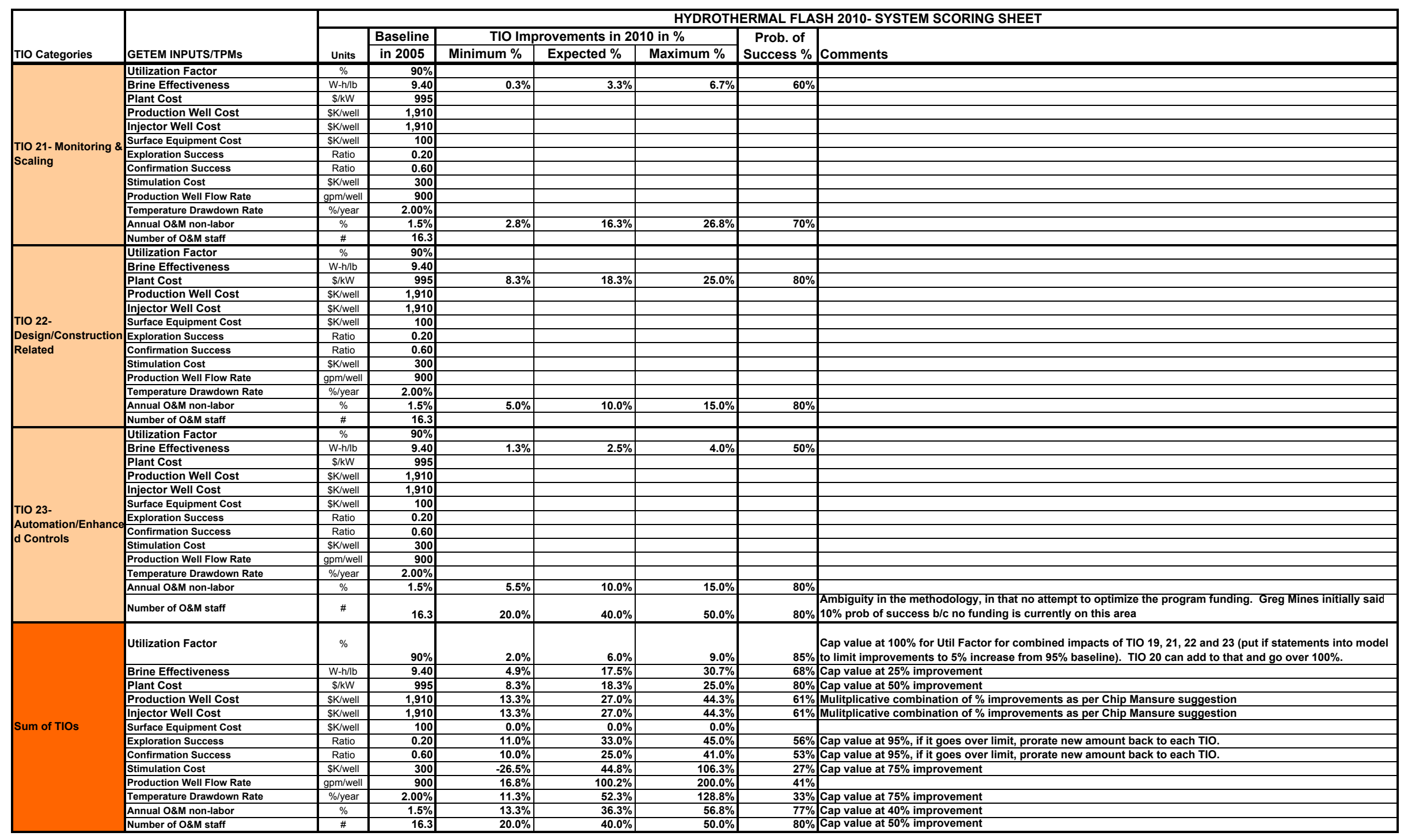




\begin{tabular}{|c|c|c|c|c|c|c|c|c|}
\hline \multirow[b]{3}{*}{ TIO Categories } & \multirow[b]{3}{*}{ GETEM INPUTS/TPMS } & \multicolumn{7}{|c|}{ EGS BINARY 2010-SYSTEM SCORING SHEET } \\
\hline & & \multirow[b]{2}{*}{ Units } & \multirow{2}{*}{\begin{tabular}{|c|} 
Baseline \\
in 2005 \\
\end{tabular}} & \multicolumn{3}{|c|}{ TIO Improvements in 2010 in \% } & \multirow{2}{*}{$\begin{array}{c}\text { Prob. of } \\
\text { Success \% }\end{array}$} & \multirow[b]{2}{*}{ Comments } \\
\hline & & & & Minimum \% & Expected \% & Maximum \% & & \\
\hline \multirow{11}{*}{$\begin{array}{l}\text { TIO 1- Increase } \\
\text { accuracy of target } \\
\text { temperature } \\
\text { prediction }\end{array}$} & \begin{tabular}{|l} 
Utilization Factor \\
\end{tabular} & $\%$ & $95 \%$ & & & & & \\
\hline & \begin{tabular}{|l} 
Brine Effectiveness \\
Plant Cost
\end{tabular} & \begin{tabular}{|l|l}
$W-h / b$ \\
$\$ / k W$
\end{tabular} & $\begin{array}{ll}10.86 \\
2,140\end{array}$ & & & & & \\
\hline & Production Well Cost & \$K/well & 4,918 & & & & & \\
\hline & Injector Well Cost & \$K/well & 4,918 & & & & & \\
\hline & Surface Equipment Cost & \$K/well & 100 & & & & & \\
\hline & Exploration Success & Ratio & 0.80 & $1.0 \%$ & $5.0 \%$ & $7.0 \%$ & $90.0 \%$ & Experts were assuming some indication of temp (spring or alteration) \\
\hline & \begin{tabular}{|l|l} 
Confirmation Success \\
Stimulation Cost
\end{tabular} & \begin{tabular}{|l|l|} 
Ratio \\
\$K/well
\end{tabular} & $\begin{array}{cc}0.80 \\
750\end{array}$ & $1.0 \%$ & $2.0 \%$ & $4.0 \%$ & $90.0 \%$ & \\
\hline & Production Well Flow Rate & $\begin{array}{ll}\text { spm/will } \\
\text { gpm/well }\end{array}$ & 332 & & & & & Group feels that the Power Found variable should be risked \\
\hline & Temperature Drawdown Rate & \%/year & $3.00 \%$ & & & & & \\
\hline & \begin{tabular}{|l|l} 
Annual O\&M non-labor \\
\end{tabular} & $\%$ & $1.5 \%$ & & & & & \\
\hline & Number of O\&M staff & $\#$ & 14.6 & & & & & \\
\hline \multirow{11}{*}{$\begin{array}{l}\text { TIO 2-Improve } \\
\text { fracture methods, } \\
\text { proppants and } \\
\text { rheology }\end{array}$} & \begin{tabular}{|l} 
Utilization Factor \\
til
\end{tabular} & $\%$ & $95 \%$ & & & & & \\
\hline & Brine Effectiveness & 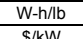 & 10.86 & & & & & \\
\hline & \begin{tabular}{|l} 
Plant Cost \\
Production Well Cost
\end{tabular} & $\begin{array}{lll}K / \text { WWell } \\
K\end{array}$ & $\frac{2,140}{4,918}$ & & & & & \\
\hline & Injector Well Cost & \$K/well & 4,918 & & & & & \\
\hline & Surface Equipment Cost & \$K/well & 100 & & & & & \\
\hline & \begin{tabular}{|l|} 
Exploration Success \\
Confirmation Success \\
\end{tabular} & \begin{tabular}{|l|l|l|l} 
Ratio \\
Ratio
\end{tabular} & $\begin{array}{ll}0.80 \\
0.80\end{array}$ & & & & & \\
\hline & Stimulation Cost & \$K/well & 750 & $-35.0 \%$ & $0.0 \%>>>$ & $50.0 \%$ & $60.0 \%$ & $\begin{array}{l}\text { Driven by petroleum industry. \% improvement likely to be very small in } 2010 \text { time frame. Might lead to more } \\
\text { expensive fluids and proppants. }\end{array}$ \\
\hline & Production Well Flow Rate & gpm/well & 332 & $5.0 \%$ & $13.0 \%$ & $25.0 \%$ & $60.0 \%$ & $\begin{array}{l}\text { lo liagnostic } \\
\text { Driven by petroleum industry. \% improvement likely to be very small in } 2010 \text { time frame. Better diag for evaluating candidates. } \\
\text { tools }\end{array}$ \\
\hline & Temperature Drawdown Rate & \%/year & $3.00 \%$ & & & & & Technology Transfer task for petroleum to geothermal techs. \\
\hline & \begin{tabular}{|l|l} 
Annual O\&M non-labor \\
\end{tabular} & $\%$ & $1.5 \%$ & & & & & \\
\hline & Number of O\&M staff & \# & 14.6 & & & & & \\
\hline \multirow{13}{*}{$\begin{array}{l}\text { TiO 3- Control of } \\
\text { fracturing - new and } \\
\text { improved borehole } \\
\text { packers }\end{array}$} & Utilization Factor & $\%$ & $95 \%$ & & & & & \\
\hline & \begin{tabular}{|l} 
Brine Effectiveness \\
Dlont
\end{tabular} & W-h/lb & 10.86 & & & & & \\
\hline & Plant Cost & $\$ / k W$ & 2,140 & & & & & \\
\hline & Production Well Cost & \$K/well & 4,918 & & & & & \\
\hline & Injector Well Cost & \$K/Well & 4,918 & & & & & \\
\hline & Surface Equipment Cost & \$K/well & 100 & & & & & \\
\hline & Exploration Success & Ratio & 0.80 & & & & & \\
\hline & Confirmation Success & Ratio & 0.80 & & & & & No field work currently going on for this. \\
\hline & Stimulation Cost & \$K/well & 750 & $-25.0 \%$ & $0.0 \%$ & $25.0 \%$ & $10.0 \%$ & Uncertain whether there would be a reduction of materials and equipment \\
\hline & Production Well Flow Rate & gpm/well & 332 & $10.0 \%$ & $17.5 \%$ & $35.0 \%$ & $25.0 \%$ & More effective fracture placement \\
\hline & Temperature Drawdown Rate & \%/year & $3.00 \%$ & & & & & \\
\hline & Annual O\&M non-labor & $\%$ & $1.5 \%$ & & & & & \\
\hline & Number of O\&M staff & $\#$ & 14.6 & & & & & \\
\hline \multirow{13}{*}{\begin{tabular}{|l} 
TIO 4- Develop \\
numerical models \\
that accurately \\
predict fracture \\
growth and \\
permeability \\
development
\end{tabular}} & Utilization Factor & $\%$ & $95 \%$ & & & & & \\
\hline & \begin{tabular}{|l|} 
Brine Effectiveness \\
\end{tabular} & W-h/lb & 10.86 & & & & & \\
\hline & Plant Cost & $\$ / \mathrm{kW}$ & 2,140 & & & & & \\
\hline & Production Well Cost & \$K/well & 4,918 & & & & & \\
\hline & Injector Well Cost & \$K/well & 4,918 & & & & & \\
\hline & Surface Equipment Cost & \$K/well & 100 & & & & & \\
\hline & Exploration Success & Ratio & 0.80 & & & & & \\
\hline & Confirmation Success & Ratio & 0.80 & & & & & \\
\hline & Stimulation Cost & \$K/well & 750 & $-20.0 \%$ & $10.0 \%$ & $30.0 \%$ & $10.0 \%$ & HHP and Materials may Increase or Decrease \\
\hline & Production Well Flow Rate & gpm/well & 332 & $10.0 \%$ & $25.0 \%$ & $50.0 \%$ & $70.0 \%$ & More effective fracture optimization \\
\hline & Temperature Drawdown Rate & \%/year & $3.00 \%$ & $4.0 \%$ & $10.0 \%$ & $15.0 \%$ & $40.0 \%$ & Haven't been able to do the testing to see if models match reality \\
\hline & Annual O\&M non-labor & $\%$ & $1.5 \%$ & & & & & \\
\hline & Number of O\&M staff & \# & 14.6 & & & & & \\
\hline
\end{tabular}




\begin{tabular}{|c|c|c|c|c|c|c|c|c|}
\hline \multirow[b]{3}{*}{ TIO Categories } & \multirow[b]{3}{*}{ GETEM INPUTS/TPMS } & \multicolumn{7}{|c|}{ EGS BINARY 2010- SYSTEM SCORING SHEET } \\
\hline & & \multirow[b]{2}{*}{ Units } & \multirow{2}{*}{\begin{tabular}{|c|} 
Baseline \\
in 2005 \\
\end{tabular}} & \multicolumn{3}{|c|}{ TIO Improvements in 2010 in \% } & \multirow{2}{*}{\begin{tabular}{|c|} 
Prob. of \\
Success \%
\end{tabular}} & \multirow[b]{2}{*}{ Comments } \\
\hline & & & & Minimum \% & Expected \% & Maximum \% & & \\
\hline \multirow{13}{*}{$\begin{array}{l}\text { TIO 5- Ability to } \\
\text { create a subsurface } \\
\text { circulation system } \\
\text { as designed }\end{array}$} & Utilization Factor & $\%$ & & & & & & \\
\hline & Brine Effectiveness & W-h/lb & 10.86 & & & & & \\
\hline & \begin{tabular}{|l} 
Plant Cost \\
\end{tabular} & $\$ / \mathrm{kW}$ & 2,140 & & & & & \\
\hline & Production Well Cost & \$K/well & 4,918 & & & & & \\
\hline & \begin{tabular}{|l|} 
Injector Well Cost \\
\end{tabular} & SK/well & 4,918 & & & & & \\
\hline & Surface Equipment Cost & \$K/well & 100 & & & & & \\
\hline & Exploration Success & Ratio & 0.80 & & & & & \\
\hline & Confirmation Success & Ratio & 0.80 & & & & & \\
\hline & Stimulation Cost & \$K/well & 750 & $-10.0 \%$ & $30.0 \%$ & $50.0 \%$ & $20.0 \%$ & Low prob of success because of no budget for testing \\
\hline & \begin{tabular}{|l|} 
Production Well Flow Rate \\
\end{tabular} & gpm/well & 332 & & & & & \\
\hline & Temperature Drawdown Rate & \%/year & $3.00 \%$ & $5.0 \%$ & $30.0 \%$ & $75.0 \%$ & $20.0 \%$ & Low prob of success because of no budget for testing \\
\hline & \begin{tabular}{|l|l|} 
Annual O\&M non-labor \\
\end{tabular} & $\%$ & $1.5 \%$ & & & & & \\
\hline & Number of O\&M staff & $\#$ & 14.6 & & & & & \\
\hline \multirow{13}{*}{$\begin{array}{l}\text { TIO 6- Develop } \\
\text { numerical models } \\
\text { that explain and } \\
\text { extend reservoir } \\
\text { performance }\end{array}$} & Utilization Factor & $\%$ & $95 \%$ & & & & & \\
\hline & Brine Effectiveness & W-h/lb & 10.86 & & & & & \\
\hline & Plant Cost & $\$ / \mathrm{kW}$ & 2,140 & & & & & \\
\hline & Production Well Cost & \$K/well & 4,918 & & & & & \\
\hline & Injector Well Cost & $\begin{array}{l}\text { SK/well } \\
\text { SK }\end{array}$ & 4,918 & & & & & \\
\hline & Surface Equipment Cost & $\begin{array}{l}\text { SW/well } \\
\text { \$K/well } \\
\end{array}$ & $\frac{4,100}{100}$ & & & & & \\
\hline & Exploration Success & Ratio & 0.80 & & & & & \\
\hline & Confirmation Success & Ratio & 0.80 & & & & & \\
\hline & \begin{tabular}{|l|l|l|l} 
Stimulation Cost \\
\end{tabular} & \$K/well & 750 & & & & & \\
\hline & Production Well Flow Rate & gpm/well & 332 & & & & & \\
\hline & Temperature Drawdown Rate & \%/year & $3.00 \%$ & $5.0 \%$ & $10.0 \%$ & $20.0 \%$ & $30.0 \%$ & Low prob of success because of no budget for long term testing of at least $1-2$ field projects \\
\hline & Annual O\&M non-labor & $\%$ & $1.5 \%$ & & & & & \\
\hline & Number of O\&M staff & $\#$ & 14.6 & & & & & \\
\hline \multirow{13}{*}{\begin{tabular}{|l} 
TIO 7-Improve \\
artificial lift \\
technology
\end{tabular}} & Utilization Factor & $\%$ & $95 \%$ & & & & & \\
\hline & Brine Effectiveness & W-h/lb & 10.86 & & & & & \\
\hline & Plant Cost & $\$ / k W$ & 2,140 & & & & & \\
\hline & Production Well Cost & \$K/well & 4,918 & & & & & \\
\hline & Injector Well Cost & SK/well & 4,918 & & & & & \\
\hline & Surface Equipment Cost & \$K/well & 100 & & & & & \\
\hline & $\begin{array}{l}\text { Uuntace Equpmentiosit } \\
\text { Exploration Success } \\
\end{array}$ & \begin{tabular}{|lll} 
Ration \\
Ratio
\end{tabular} & 0.80 & & & & & \\
\hline & \begin{tabular}{|l|l} 
Confirmation Success \\
\end{tabular} & Ratio & 0.80 & & & & & \\
\hline & Stimulation Cost & \$K/well & 750 & & & & & \\
\hline & Production Well Flow Rate & gpm/well & 332 & $1.0 \%$ & $50.0 \%$ & $200.0 \%$ & $15.0 \%$ & Low prob of success because of no budget for testing \\
\hline & Temperature Drawdown Rate & \%/year & $3.00 \%$ & & & & & \\
\hline & Annual O\&M non-labor & $\%$ & $1.5 \%$ & & & & & Team thinks this TIO will have an impact on non-labor O\&M, but don't know how much \\
\hline & Number of O\&M staff & \# & 14.6 & & & & & \\
\hline \multirow{13}{*}{$\begin{array}{l}\text { TIO 8- Improve shor } \\
\text { circuit mitigation } \\
\text { methods }\end{array}$} & Utilization Factor & $\%$ & $95 \%$ & & & & & \\
\hline & Brine Effectiveness & W-h/lb & 10.86 & & & & & \\
\hline & Plant Cost & $\$ / \mathrm{kW}$ & 2,140 & & & & & \\
\hline & Production Well Cost & \$K/well & 4,918 & & & & & \\
\hline & Injector Well Cost & \$K/well & 4,918 & & & & & \\
\hline & Surface Equipment Cost & \$K/well & 100 & & & & & \\
\hline & Exploration Success & \begin{tabular}{|lll} 
Ration \\
Ratio
\end{tabular} & 0.80 & & & & & \\
\hline & \begin{tabular}{|l|} 
Confirmation Success \\
\end{tabular} & Ratio & 0.80 & & & & & \\
\hline & Stimulation Cost & \$K/well & 750 & $1.0 \%$ & $25.0 \%$ & $50.0 \%$ & $10.0 \%$ & Enabling TIO that will allow other TIOs to improve technology. \\
\hline & \begin{tabular}{|l|} 
Production Well Flow Rate \\
\end{tabular} & gpm/well & 332 & $1.0 \%$ & $50.0 \%$ & $100.0 \%$ & $10.0 \%$ & Low prob of success because of no budget for testing \\
\hline & Temperature Drawdown Rate & \%/year & $3.00 \%$ & & & & & \\
\hline & Annual O\&M non-labor & $\%$ & $1.5 \%$ & & & & & \\
\hline & Number of O\&M staff & \# & 14.6 & & & & & \\
\hline
\end{tabular}




\begin{tabular}{|c|c|c|c|c|c|c|c|c|}
\hline \multirow[b]{3}{*}{ TIO Categories } & \multirow[b]{3}{*}{ GETEM INPUTS/TPMS } & \multicolumn{7}{|c|}{ EGS BINARY 2010-SYSTEM SCORING SHEET } \\
\hline & & \multirow[b]{2}{*}{ Units } & \multirow{2}{*}{\begin{tabular}{|c|} 
Baseline \\
in 2005 \\
\end{tabular}} & \multicolumn{3}{|c|}{ TIO Improvements in 2010 in \% } & \multirow{2}{*}{$\begin{array}{c}\text { Prob. of } \\
\text { Success \% }\end{array}$} & \multirow[b]{2}{*}{ Comments } \\
\hline & & & & Minimum \% & Expected \% & Maximum \% & & \\
\hline \multirow{13}{*}{$\begin{array}{l}\text { TIO 9- Perform } \\
\text { systems analysis } \\
\text { and integration }\end{array}$} & Utilization Factor & $\%$ & $95 \%$ & & & & & \\
\hline & Brine Effectiveness & W-h/lb & 10.86 & & & & & \\
\hline & Plant Cost & $\$ / \mathrm{kW}$ & 2,140 & & & & & \\
\hline & Production Well Cost & \$K/well & 4,918 & & & & & \\
\hline & Injector Well Cost & \$K/well & 4,918 & & & & & \\
\hline & Surface Equipment Cost & \$K/well & 100 & & & & & \\
\hline & Exploration Success & Ratio & 0.80 & & & & & Team notes that this is for technical systems analysis and not program systems analysis \\
\hline & Confirmation Success & Ratio & 0.80 & & & & & \\
\hline & Stimulation Cost & \$K/well & 750 & $10.0 \%$ & $15.0 \%$ & $20.0 \%$ & $50.0 \%$ & \\
\hline & Production Well Flow Rate & gpm/well & 332 & $1.0 \%$ & $5.0 \%$ & $10.0 \%$ & $70.0 \%$ & \\
\hline & \begin{tabular}{|l|l} 
Temperature Drawdown Rate \\
\end{tabular} & \%olyear & $3.00 \%$ & $1.0 \%$ & $25.0 \%$ & $75.0 \%$ & $40.0 \%$ & Low prob of success because of no budget for testing \\
\hline & \begin{tabular}{|l|l} 
Annual O\&M non-labor \\
\end{tabular} & $\%$ & $3.5 \%$ & & & & & 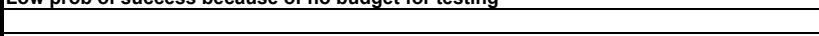 \\
\hline & Number of O\&M staff & $\#$ & 14.6 & & & & & \\
\hline \multirow{13}{*}{$\begin{array}{l}\text { TIO 10- Remote } \\
\text { sensing exploration } \\
\text { methods (InSAR, } \\
\text { hyperspectral } \\
\text { imaging, GPS) }\end{array}$} & Utilization Factor & $\%$ & $95 \%$ & & & & & \\
\hline & Brine Effectiveness & W-h/lb & 10.86 & & & & & \\
\hline & Plant Cost & $\$ / k W$ & 2,140 & & & & & \\
\hline & Production Well Cost & \$K/well & 4,918 & & & & & \\
\hline & Injector Well Cost & \$K/well & 4,918 & & & & & \\
\hline & Surface Equipment Cost & \$K/well & 100 & & & & & \\
\hline & Exploration Success & Ratio & 0.80 & $1.0 \%$ & $7.0 \%$ & $10.0 \%$ & $25 \%$ & Group feels that the Power Found variable should be risked \\
\hline & Confirmation Success & Ratio & 0.80 & $1.0 \%$ & $5.0 \%$ & $8.0 \%$ & $12 \%$ & \\
\hline & Stimulation Cost & \$K/well & 750 & & & & & \\
\hline & Production Well Flow Rate & gpm/well & 332 & & & & & \\
\hline & Temperature Drawdown Rate & \%/year & $3.00 \%$ & & & & & \\
\hline & Annual O\&M non-labor & $\%$ & $1.5 \%$ & & & & & \\
\hline & Number of O\&M staff & $\#$ & 14.6 & & & & & \\
\hline \multirow{13}{*}{$\begin{array}{l}\text { TiO 11- Geophysical } \\
\text { exploration methods } \\
\text { (seismic, } \\
\text { magnetotellurics) }\end{array}$} & Utilization Factor & $\%$ & $95 \%$ & & & & & \\
\hline & Brine Effectiveness & W-h/lb & 10.86 & & & & & \\
\hline & Plant Cost & $\$ / k W$ & 2,140 & & & & & \\
\hline & Production Well Cost & \$K/well & 4,918 & & & & & \\
\hline & Injector Well Cost & \$K/well & 4,918 & & & & & \\
\hline & Surface Equipment Cost & \$K/well & 100 & & & & & \\
\hline & Exploration Success & $\begin{array}{ll}\text { Ratio } \\
\end{array}$ & 0.80 & $4.0 \%$ & $6.0 \%$ & $8.0 \%$ & $60 \%$ & \\
\hline & Confirmation Success & $\begin{array}{ll}\text { Ratio } \\
\end{array}$ & 0.80 & $7.0 \%$ & $10.0 \%$ & $14.0 \%$ & $60 \%$ & \\
\hline & Stimulation Cost & \$K/well & 750 & & & & & \\
\hline & Production Well Flow Rate & gpm/well & 332 & & & & & \\
\hline & Temperature Drawdown Rate & \%/year & $3.00 \%$ & & & & & \\
\hline & \begin{tabular}{|l|} 
Annual O\&M non-labor \\
\end{tabular} & $\%$ & $1.5 \%$ & & & & & \\
\hline & Number of O\&M staff & \# & 14.6 & & & & & \\
\hline \multirow{13}{*}{\begin{tabular}{|} 
TIO 12- Geochemical \\
exploration methods \\
(isotopes, gases)
\end{tabular}} & Utilization Factor & $\%$ & $95 \%$ & & & & & \\
\hline & \begin{tabular}{|l|} 
Brine Effectiveness \\
\end{tabular} & W-h/lb & 10.86 & & & & & \\
\hline & Plant Cost & $\$ / \mathrm{kW}$ & 2,140 & & & & & \\
\hline & Production Well Cost & \$K/well & 4,918 & & & & & \\
\hline & Injector Well Cost & \$K/well & 4,918 & & & & & \\
\hline & Surface Equipment Cost & \$K/well & 100 & & & & & \\
\hline & Exploration Success & Ratio & 0.80 & $5.0 \%$ & $15.0 \%$ & $20.0 \%$ & $50 \%$ & Group feels that the Power Found variable should be risked \\
\hline & Confirmation Success & Ratio & 0.80 & $1.0 \%$ & $8.0 \%$ & $15.0 \%$ & $50 \%$ & \\
\hline & Stimulation Cost & \$K/well & 750 & & & & & \\
\hline & Production Well Flow Rate & gpm/well & 332 & & & & & \\
\hline & Temperature Drawdown Rate & \%/year & $3.00 \%$ & & & & & \\
\hline & Annual O\&M non-labor & $\%$ & $1.5 \%$ & & & & & \\
\hline & Number of O\&M staff & \# & 14.6 & & & & & \\
\hline
\end{tabular}




\begin{tabular}{|c|c|c|c|c|c|c|c|c|}
\hline \multirow[b]{3}{*}{ TIO Categories } & \multirow[b]{3}{*}{ GETEM INPUTS/TPMS } & \multicolumn{7}{|c|}{ EGS BINARY 2010- SYSTEM SCORING SHEET } \\
\hline & & \multirow[b]{2}{*}{ Units } & \multirow{2}{*}{\begin{tabular}{|c|} 
Baseline \\
in 2005 \\
\end{tabular}} & \multicolumn{3}{|c|}{ TIO Improvements in 2010 in \% } & \multirow{2}{*}{$\begin{array}{c}\text { Prob. of } \\
\text { Success \% }\end{array}$} & \multirow[b]{2}{*}{ Comments } \\
\hline & & & & Minimum \% & Expected \% & Maximum \% & & \\
\hline \multirow{13}{*}{$\begin{array}{l}\text { TIO 13- National } \\
\text { geothermal } \\
\text { assessment and } \\
\text { supply (EGS, } \\
\text { hydrothermal) }\end{array}$} & \begin{tabular}{|l} 
Utilization Factor \\
\end{tabular} & & $95 \%$ & & & & & \\
\hline & Brine Effectiveness & W-h/b & 10.86 & & & & & \\
\hline & Plant Cost & $\$ / k W$ & 2,140 & & & & & \\
\hline & Production Well Cost & \$K/well & 4,918 & & & & & \\
\hline & Injector Well Cost & \$K/well & 4,918 & & & & & \\
\hline & Surface Equipment Cost & \$K/well & 100 & & & & & \\
\hline & Exploration Success & Ratio & 0.80 & & & & & $\begin{array}{l}\text { Really an enabling TIO that allows the other improvements to be made. Needs to be done to support or } \\
\text { ondemn the program. Industry has been pushing for this (thinking that it would be the program going out } \\
\text { and actually drilling wells). }\end{array}$ \\
\hline & \begin{tabular}{|l} 
Confirmation Success \\
\end{tabular} & Ratio & 0.80 & & & & & \\
\hline & Stimulation Cost & \$K/well & 750 & & & & & \\
\hline & \begin{tabular}{|l} 
Production Well Flow Rate \\
\end{tabular} & $\mathrm{gpm} / \mathrm{well}$ & 332 & & & & & \\
\hline & Temperature Drawdown Rate & \%/year & $3.00 \%$ & & & & & \\
\hline & \begin{tabular}{|l|l|} 
Annual O\&M non-labor \\
\end{tabular} & $\%$ & $1.5 \%$ & & & & & \\
\hline & Number of O\&M staff & $\#$ & 14.6 & & & & & \\
\hline \multirow{13}{*}{$\begin{array}{l}\text { TIO 14- Reduction o } \\
\text { drilling time and } \\
\text { expense, especially } \\
\text { in hard abrasive } \\
\text { formations }\end{array}$} & Utilization Factor & $\%$ & $95 \%$ & & & & & \\
\hline & \begin{tabular}{|l|} 
Brine Effectiveness \\
\end{tabular} & W-h/lb & 10.86 & & & & & \\
\hline & \begin{tabular}{|l|l|l|l|l} 
Plant Cost \\
\end{tabular} & $\$ / k W$ & 2,140 & & & & & \\
\hline & Production Well Cost & \$K/well & 4,918 & $5.0 \%$ & $12.0 \%$ & $20.0 \%$ & $65 \%$ & \\
\hline & Injector Well Cost & \$K/well & 4,918 & $5.0 \%$ & $12.0 \%$ & $20.0 \%$ & $65 \%$ & \\
\hline & Surface Equipment Cost & \$K/well & 100 & & & & & \\
\hline & Exploration Success & Ratio & 0.80 & & & & & \\
\hline & \begin{tabular}{|l|} 
Confirmation Success \\
\end{tabular} & Ratio & 0.80 & & & & & \\
\hline & Stimulation Cost & \$K/well & 750 & & & & & \\
\hline & \begin{tabular}{|l|} 
Production Well Flow Rate \\
\end{tabular} & gpm/well & 332 & & & & & \\
\hline & Temperature Drawdown Rate & \%/year & $3.00 \%$ & & & & & \\
\hline & Annual O\&M non-labor & $\%$ & $1.5 \%$ & & & & & \\
\hline & Number of O\&M staff & $\#$ & 14.6 & & & & & \\
\hline \multirow{13}{*}{\begin{tabular}{|l} 
TIO 15- Reduction \\
time and expense to \\
line the wellbore \\
(including using les \\
material and less \\
costly material)
\end{tabular}} & Utilization Factor & $\%$ & $95 \%$ & & & & & \\
\hline & \begin{tabular}{|l|} 
Brine Effectiveness \\
\end{tabular} & W-h/lb & 10.86 & & & & & \\
\hline & Plant Cost & $\$ / k W$ & 2,140 & & & & & \\
\hline & Production Well Cost & SK/well & 4,918 & $4.0 \%$ & $10.0 \%$ & $15.0 \%$ & $50 \%$ & \\
\hline & \begin{tabular}{|l|} 
Injector Well Cost \\
\end{tabular} & \$K/well & 4,918 & $4.0 \%$ & $10.0 \%$ & $15.0 \%$ & $50 \%$ & \\
\hline & Surface Equipment Cost & \$K/well & 100 & & & & & \\
\hline & \begin{tabular}{|l|} 
Exploration Success \\
\end{tabular} & Ratio & 0.80 & & & & & \\
\hline & Confirmation Success & Ratio & 0.80 & & & & & \\
\hline & Stimulation Cost & \$K/well & 750 & & & & & \\
\hline & \begin{tabular}{|l|l|l|l|l|} 
Production Well Rate \\
\end{tabular} & $\mathrm{gpm} / \mathrm{well}$ & 332 & & & & & \\
\hline & Temperature Drawdown Rate & \%/year & $3.00 \%$ & & & & & \\
\hline & \begin{tabular}{|l|l} 
Annual O\&M non-labor \\
\end{tabular} & $\%$ & $1.5 \%$ & & & & & \\
\hline & Number of O\&M staff & $\#$ & 14.6 & & & & & \\
\hline \multirow{13}{*}{\begin{tabular}{|l} 
TIO 16- Reduction of \\
non-essential flat \\
time
\end{tabular}} & Utilization Factor & $\%$ & $95 \%$ & & & & & \\
\hline & Brine Effectiveness & W-h/lb & 10.86 & & & & & \\
\hline & Plant Cost & $\Phi / \mathrm{kW}$ & 2,140 & & & & & \\
\hline & Production Well Cost & 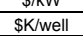 & $\frac{2,4048}{4,918}$ & $2.0 \%$ & $4.0 \%$ & $10.0 \%$ & $50 \%$ & \\
\hline & Injector Well Cost & $\begin{array}{l}\text { SK/well } \\
\text { KK/well }\end{array}$ & $4,4,918$ & $2.0 \%$ & $\begin{array}{l}4.0 \% \\
4.0 \% \\
\end{array}$ & $10.0 \%$ & $50 \%$ & \\
\hline & Surface Equipment Cost & $\begin{array}{l}\text { SK/well } \\
\text { SKell }\end{array}$ & 100 & & & & & \\
\hline & Exploration Success & Ratio & 0.80 & & & & & \\
\hline & \begin{tabular}{|l|} 
Confirmation Success \\
\end{tabular} & Ratio & 0.80 & & & & & \\
\hline & Stimulation Cost & \$K/well & 750 & & & & & \\
\hline & Production Well Flow Rate & gpm/well & 332 & & & & & \\
\hline & Temperature Drawdown Rate & \%/year & $3.00 \%$ & & & & & \\
\hline & Annual O\&M non-labor & $\%$ & $1.5 \%$ & & & & & \\
\hline & Number of O\&M staff & \# & 14.6 & & & & & \\
\hline
\end{tabular}




\begin{tabular}{|c|c|c|c|c|c|c|c|c|}
\hline \multirow[b]{3}{*}{ TIO Categories } & \multirow[b]{3}{*}{ GETEM INPUTS/TPMS } & \multicolumn{7}{|c|}{ EGS BINARY 2010- SYSTEM SCORING SHEET } \\
\hline & & \multirow[b]{2}{*}{ Units } & \multirow{2}{*}{\begin{tabular}{|c|} 
Baseline \\
in 2005 \\
\end{tabular}} & \multicolumn{3}{|c|}{ TIO Improvements in 2010 in \% } & \multirow{2}{*}{\begin{tabular}{|c|} 
Prob. of \\
Success \%
\end{tabular}} & \multirow[b]{2}{*}{ Comments } \\
\hline & & & & Minimum \% & Expected \% & Maximum \% & & \\
\hline \multirow{13}{*}{$\begin{array}{l}\text { TIO 17- Developmen } \\
\text { of basic information } \\
\text { through analysis } \\
\text { and simulation } \\
\text { efforts. }\end{array}$} & \begin{tabular}{|l} 
Utilization Factor \\
\end{tabular} & $\%$ & $95 \%$ & & & & & \\
\hline & \begin{tabular}{|l|l} 
Brine Effectiveness \\
\end{tabular} & W-h/lb & 10.86 & & & & & \\
\hline & Plant Cost & $\$ / k W$ & 2,140 & & & & & \\
\hline & Production Well Cost & \$K/well & 4,918 & $4.0 \%$ & $8.0 \%$ & $12.0 \%$ & $75 \%$ & \\
\hline & Injector Well Cost & $\begin{array}{lll}\text { SK/well } \\
\end{array}$ & 4,918 & $4.0 \%$ & $8.0 \%$ & $12.0 \%$ & $75.0 \%$ & More interested in rock mechanics in EGS case then in rock formation \\
\hline & Surface Equipment Cost & $\begin{array}{lll}\text { SW/well } \\
\text { SKell }\end{array}$ & $\frac{4,100}{100}$ & & & & & 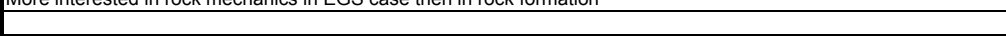 \\
\hline & Exploration Success & $\begin{array}{lll}\text { Rateil } \\
\text { Ratio } \\
\end{array}$ & 0.80 & & & & & \\
\hline & Confirmation Success & Ratio & 0.80 & & & & & \\
\hline & Stimulation Cost & \$K/well & 750 & & & & & \\
\hline & \begin{tabular}{|l|} 
Production Well Flow Rate \\
\end{tabular} & gpm/well & 332 & & & & & \\
\hline & Temperature Drawdown Rate & \%olyear & $3.00 \%$ & & & & & \\
\hline & Annual O\&M non-labor & $\%$ & $0.00 \%$ & & & & & \\
\hline & \begin{tabular}{|l} 
Number of O\&M staff \\
\end{tabular} & $\#$ & 14.6 & & & & & \\
\hline \multirow{12}{*}{$\begin{array}{l}\text { TIO 18-Completion } \\
\text { and production } \\
\text { related developmen } \\
\text { projects }\end{array}$} & \begin{tabular}{|l|l|l} 
Utilization Factor \\
Brine Effectiveness
\end{tabular} & \begin{tabular}{c|c|c|}
$\%$ \\
W-h/b
\end{tabular} & $\begin{aligned} 95 \% \\
10.86\end{aligned}$ & & & & & \\
\hline & \begin{tabular}{|l} 
Brine Effectiveness \\
Plant Cost
\end{tabular} & \begin{tabular}{|l|l} 
W-h/lb \\
$\Phi / k W$
\end{tabular} & $\frac{10.86}{2,140}$ & & & & & \\
\hline & Production Well Cost & SK/well & 4,918 & $2.5 \%$ & $4.0 \%$ & $7.0 \%$ & $60 \%$ & \\
\hline & Injector Well Cost & \$K/well & 4,918 & $2.5 \%$ & $4.0 \%$ & $7.0 \%$ & $60 \%$ & \\
\hline & Surface Equipment Cost & \$K/well & 100 & & & & & \\
\hline & Exploration Success & 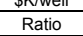 & 0.80 & & & & & \\
\hline & \begin{tabular}{|l|} 
Confirmation Success \\
\end{tabular} & Ratio & 0.80 & & & & & \\
\hline & \begin{tabular}{|l|} 
Stimulation Cost \\
\end{tabular} & \$K/well & 750 & & & & & \\
\hline & Production Well Flow Rate & gpm/well & 332 & & & & & \\
\hline & Temperature Drawdown Rate & \%/year & $3.00 \%$ & & & & & \\
\hline & Annual O\&M non-labor & $\%$ & $1.5 \%$ & & & & & $\begin{array}{l}\text { One expert thought this TIO might have a small impact on fields in terms of life cycle costs, with the exception } \\
\text { of very corrosive or very hot fields. }\end{array}$ \\
\hline & Number of O\&M staff & \# & 14.6 & & & & & \\
\hline \multirow{13}{*}{$\begin{array}{l}\text { TIO 19-Cycle } \\
\text { Related }\end{array}$} & Utilization Factor & $\%$ & $95 \%$ & $1.0 \%$ & $3.0 \%$ & $4.0 \%$ & $90 \%$ & $\begin{array}{l}\text { Some experts were concerned that a 200C resource is too high for binary technology, and that it might be } \\
\text { better for flashed-steam technology, but another expert said that } 200 \mathrm{C} \text { is needed because super-high } \\
\text { pressure must be maintained. }\end{array}$ \\
\hline & Brine Effectiveness & W-h/lb & 10.86 & $10.0 \%$ & $25.0 \%$ & $40.0 \%$ & $90 \%$ & There are opportunities to optimize plant configuration that would improve brine effectiveness. \\
\hline & Plant Cost & $\$ / \mathrm{kW}$ & 2,140 & $-10.0 \%$ & $10.0 \%$ & $30.0 \%$ & $30 \%$ & \\
\hline & Production Well Cost & \$K/well & 4,918 & & & & & \\
\hline & Injector Well Cost & \$K/well & 4,918 & & & & & \\
\hline & Surface Equipment Cost & \$K/well & 100 & & & & & \\
\hline & Exploration Success & Ratio & 0.80 & & & & & \\
\hline & Confirmation Success & Ratio & 0.80 & & & & & \\
\hline & Stimulation Cost & \$K/well & 750 & & & & & \\
\hline & Production Well Flow Rate & gpm/well & 332 & & & & & \\
\hline & Temperature Drawdown Rate & \%/year & $3.00 \%$ & & & & & \\
\hline & Annual O\&M non-labor & $\%$ & $1.5 \%$ & & & & & \\
\hline & Number of O\&M staff & \# & 14.6 & & & & & \\
\hline \multirow{13}{*}{\begin{tabular}{|l} 
TiO 20-Component \\
Related
\end{tabular}} & Utilization Factor & $\%$ & $95 \%$ & $1.0 \%$ & $3.0 \%$ & $4.0 \%$ & $80 \%$ & \\
\hline & Brine Effectiveness & W-h/lb & 10.86 & $3.3 \%$ & $8.0 \%$ & $12.5 \%$ & $75 \%$ & \\
\hline & \begin{tabular}{|l|} 
Plant Cost \\
\end{tabular} & $\$ / k W$ & 2,140 & $2.0 \%$ & $5.0 \%$ & $8.0 \%$ & $75 \%$ & \\
\hline & Production Well Cost & \$K/well & 4,918 & & & & & \\
\hline & Injector Well Cost & $\begin{array}{l}\text { SK/well } \\
\text { \$K/Well }\end{array}$ & $4,4,918$ & & & & & \\
\hline & Surface Equipment Cost & \$K/well & 100 & & & & & \\
\hline & Exploration Success & Ratio & 0.80 & & & & & \\
\hline & Confirmation Success & Ratio & 0.80 & & & & & \\
\hline & Stimulation Cost & \$K/well & 750 & & & & & \\
\hline & Production Well Flow Rate & gpm/well & 332 & & & & & \\
\hline & Temperature Drawdown Rate & \%/year & $3.00 \%$ & & & & & \\
\hline & Annual O\&M non-labor & $\%$ & $1.5 \%$ & $0.0 \%$ & $5.0 \%$ & $8.0 \%$ & $50 \%$ & \\
\hline & Number of O\&M staff & \# & 14.6 & & & & & \\
\hline
\end{tabular}




\begin{tabular}{|c|c|c|c|c|c|c|c|c|}
\hline \multirow[b]{3}{*}{ TIO Categories } & \multirow[b]{3}{*}{ GETEM INPUTS/TPMS } & \multicolumn{7}{|c|}{ EGS BINARY 2010- SYSTEM SCORING SHEET } \\
\hline & & \multirow[b]{2}{*}{ Units } & \multirow{2}{*}{\begin{tabular}{|c|} 
Baseline \\
in 2005 \\
\end{tabular}} & \multicolumn{3}{|c|}{ TIO Improvements in 2010 in \% } & \multirow{2}{*}{$\begin{array}{r}\text { Prob. of } \\
\text { Success \% }\end{array}$} & \multirow[b]{2}{*}{ Comments } \\
\hline & & & & Minimum \% & Expected \% & Maximum \% & & \\
\hline \multirow{13}{*}{$\begin{array}{l}\text { TIO 21- Monitoring \& } \\
\text { Scaling }\end{array}$} & Utilization Factor & & $95 \%$ & $0.0 \%$ & $0.3 \%$ & $0.5 \%$ & $30 \%$ & \\
\hline & \begin{tabular}{|l|} 
Brine Effectiveness \\
\end{tabular} & W-h/lb & 10.86 & $2.5 \%$ & $6.5 \%$ & $10.0 \%$ & $55 \%$ & \\
\hline & Plant Cost & $\$ / k W$ & 2,140 & & & & & \\
\hline & Production Well Cost & \$K/well & 4,918 & & & & & \\
\hline & Injector Well Cost & \$K/well & 4,918 & & & & & \\
\hline & Surface Equipment Cost & \$K/well & 100 & & & & & \\
\hline & Exploration Success & Ratio & 0.80 & & & & & \\
\hline & \begin{tabular}{|l|} 
Confirmation Success \\
\end{tabular} & Ratio & 0.80 & & & & & \\
\hline & Stimulation Cost & \$K/well & 750 & & & & & \\
\hline & \begin{tabular}{|l} 
Production Well Flow Rate \\
\end{tabular} & gpm/well & 332 & & & & & \\
\hline & Temperature Drawdown Rate & \%/year & $3.00 \%$ & & & & & \\
\hline & \begin{tabular}{|l|l|} 
Annual O\&M non-labor \\
\end{tabular} & $\%$ & $1.5 \%$ & $2.8 \%$ & $17.0 \%$ & $40.0 \%$ & $65 \%$ & \\
\hline & Number of O\&M staff & $\#$ & 14.6 & & & & & \\
\hline \multirow{13}{*}{\begin{tabular}{|l|} 
TIO 22- \\
Design/Construction \\
Related
\end{tabular}} & \begin{tabular}{|l} 
Utilization Factor \\
\end{tabular} & $\%$ & $95 \%$ & $0.0 \%$ & $2.0 \%$ & $5.0 \%$ & $50 \%$ & \\
\hline & Brine Effectiveness & W-h/lb & 10.86 & & & & & \\
\hline & \begin{tabular}{|l|l|l|l|l} 
Plant Cost \\
\end{tabular} & $\Phi / k W$ & 2,140 & $6.0 \%$ & $16.0 \%$ & $25.0 \%$ & $75 \%$ & \\
\hline & \begin{tabular}{|l|} 
Production Well Cost \\
\end{tabular} & \$K/well & 4,918 & & & & & \\
\hline & Injector Well Cost & \$K/well & 4,918 & & & & & \\
\hline & Surface Equipment Cost & \$K/well & 100 & & & & & \\
\hline & Exploration Success & Ratio & 0.80 & & & & & \\
\hline & \begin{tabular}{|l|l|l|l} 
Confirmation Success \\
\end{tabular} & Ratio & 0.80 & & & & & \\
\hline & \begin{tabular}{|l|l} 
Stimulation Cost \\
\end{tabular} & \$K/well & 750 & & & & & \\
\hline & \begin{tabular}{|l|} 
Production Well Flow Rate \\
\end{tabular} & gpm/well & 332 & & & & & \\
\hline & Temperature Drawdown Rate & \%/year & $3.00 \%$ & & & & & \\
\hline & \begin{tabular}{|l|} 
Annual O\&M non-labor \\
\end{tabular} & $\%$ & $1.5 \%$ & & & & & \\
\hline & Number of O\&M staff & $\#$ & 14.6 & & & & & \\
\hline \multirow{13}{*}{$\begin{array}{l}\text { TIO 23- } \\
\text { Automation/Enhance } \\
\text { d Controls }\end{array}$} & \begin{tabular}{|l} 
Utilization Factor \\
\end{tabular} & $\%$ & $95 \%$ & $0.5 \%$ & $1.7 \%$ & $2.7 \%$ & $75 \%$ & \\
\hline & \begin{tabular}{|l|} 
Brine Effectiveness \\
\end{tabular} & W-h/lb & 10.86 & & & & & \\
\hline & \begin{tabular}{|l} 
\\
Plant Cost
\end{tabular} & $\$ / \mathrm{kW}$ & 2,140 & $-2.0 \%$ & $-1.0 \%$ & $-0.5 \%$ & $75 \%$ & \\
\hline & Production Well Cost & \$K/well & 4,918 & & & & & \\
\hline & Injector Well Cost & \$K/well & 4,918 & & & & & \\
\hline & Surface Equipment Cost & \$K/well & 100 & & & & & \\
\hline & Exploration Success & Ratio & 0.80 & & & & & \\
\hline & Confirmation Success & Ratio & 0.80 & & & & & \\
\hline & \begin{tabular}{|l|} 
Stimulation Cost \\
\end{tabular} & \$K/well & 750 & & & & & \\
\hline & Production Well Flow Rate & gpm/well & 332 & & & & & \\
\hline & \begin{tabular}{|l} 
Temperature Drawdown Rate \\
\end{tabular} & \%/year & $3.00 \%$ & & & & & \\
\hline & \begin{tabular}{|l|} 
Annual O\&M non-labor \\
\end{tabular} & $\%$ & $1.5 \%$ & $-5.0 \%$ & $0.0 \%$ & $5.0 \%$ & $65 \%$ & \\
\hline & Number of O\&M staff & $\#$ & 14.6 & $20.0 \%$ & $35.0 \%$ & $50.0 \%$ & $75 \%$ & \\
\hline \multirow{13}{*}{ Sum of TIOs } & Utilization Factor & $\%$ & $95 \%$ & $2.5 \%$ & $10.0 \%$ & $16.2 \%$ & $65 \%$ & $\begin{array}{l}\text { Cap value at } 100 \% \text { for Util Factor for combined impacts of TIO } 19,21,22 \text { and } 23 \text { (put if statements into model } \\
\text { to limit improvements to } 5 \% \text { increase from } 95 \% \text { baseline). TIO } 20 \text { can add to that and go over } 100 \% \text {. }\end{array}$ \\
\hline & Brine Effectiveness & W-h/lb & 10.86 & \begin{tabular}{|c|c|}
$15.8 \%$ \\
\end{tabular} & $39.5 \%$ & $62.5 \%$ & $73 \%$ & Cap value at $25 \%$ improvement \\
\hline & Plant Cost & $\Phi / \mathrm{kW}$ & 2,140 & $-4.0 \%$ & $30.0 \%$ & $62.5 \%$ & $64 \%$ & Cap value at $50 \%$ improvement \\
\hline & Production Well Cost & $\$$ \$K/Well & $\frac{2,4018}{4,918}$ & $\frac{-4.04 \%}{16.3 \%}$ & $32.8 \%$ & 49.9\% & $60 \%$ & Mulitplicative combination of \% improvements as per Chip Mansure suggestion \\
\hline & Injector Well Cost & $\begin{array}{l}\text { SK/well } \\
\text { SK/well }\end{array}$ & 4,918 & $16.3 \%$ & 32.8\% & 49.9\% & $60 \%$ & Mulitplicative combination of \% improvements as per Chip Mansure suggestion \\
\hline & Surface Equipment Cost & Sk/well & 100 & $0.0 \%$ & $0.0 \%$ & $0.0 \%$ & & \\
\hline & Exploration Success & Ratio & 0.80 & $11.0 \%$ & $33.0 \%$ & $45.0 \%$ & $56 \%$ & Cap value at $95 \%$, if it goes over limit, prorate new amount back to each TIO. \\
\hline & Confirmation Success & Ratio & 0.80 & $10.0 \%$ & $25.0 \%$ & $41.0 \%$ & $53 \%$ & Cap value at $95 \%$, if it goes over limit, prorate new amount back to each TIO. \\
\hline & Stimulation Cost & \$K/well & 750 & $-79.0 \%$ & $80.0 \%$ & $225.0 \%$ & $27 \%$ & Cap value at $75 \%$ improvement \\
\hline & \begin{tabular}{|l|l|l} 
Production Well Flow Rate \\
\end{tabular} & $\mathrm{gpm} / \mathrm{well}$ & 332 & $28.0 \%$ & $160.5 \%$ & $420.0 \%$ & $42 \%$ & \\
\hline & Temperature Drawdown Rate & \%/year & $3.00 \%$ & $15.0 \%$ & $75.0 \%$ & $185.0 \%$ & $33 \%$ & Cap value at $75 \%$ improvement \\
\hline & Annual O\&M non-labor & $\%$ & $1.5 \%$ & $-2.3 \%$ & $22.0 \%$ & $53.0 \%$ & $60 \%$ & Cap value at $40 \%$ improvement \\
\hline & Number of O\&M staff & \# & 14.6 & $20.0 \%$ & $35.0 \%$ & $50.0 \%$ & $75 \%$ & Cap value at $50 \%$ improvement \\
\hline
\end{tabular}




\begin{tabular}{|c|c|c|c|c|c|c|c|c|}
\hline \multirow[b]{3}{*}{ TIO Categories } & \multirow[b]{3}{*}{ GETEM INPUTS/TPMS } & \multicolumn{7}{|c|}{ EGS FLASH 2010- SYSTEM SCORING SHEET } \\
\hline & & \multirow[b]{2}{*}{ Units } & \multirow{2}{*}{$\begin{array}{l}\text { Baseline } \\
\text { in } 2005\end{array}$} & \multicolumn{3}{|c|}{ TIO Improvements in 2010 in \% } & \multirow{2}{*}{\begin{tabular}{c|} 
Prob. of \\
Success \%
\end{tabular}} & \multirow{2}{*}{ Comments } \\
\hline & & & & Minimum \% & Expected \% & Maximum \% & & \\
\hline \multirow{13}{*}{$\begin{array}{l}\text { TIO 1- Increase } \\
\text { accuracy of target } \\
\text { temperature } \\
\text { prediction }\end{array}$} & Utilization Factor & $\%$ & & & & & & \\
\hline & Brine Effectiveness & W-h/lb & 16.28 & & & & & \\
\hline & Plant Cost & $\$ / \mathrm{kW}$ & 940 & & & & & \\
\hline & Production Well Cost & SK/well & 12,530 & & & & & \\
\hline & Injector Well Cost & SK/well & 12,530 & & & & & \\
\hline & Surface Equipment Cost & SK/well & 100 & & & & & \\
\hline & Exploration Success & Ratio & 0.80 & $1.0 \%$ & $5.0 \%$ & $7.0 \%$ & $90 \%$ & Assumed that this EGS TIO impacts the EGS Flash case at $100 \%$ of the EGS Binary case. \\
\hline & Confirmation Success & Ratio & 0.80 & $1.0 \%$ & $2.0 \%$ & $4.0 \%$ & $90 \%$ & Assumed that this EGS TIO impacts the EGS Flash case at $100 \%$ of the EGS Binary case. \\
\hline & Stimulation Cost & SK/well & $\frac{0.00}{750}$ & & & & & \\
\hline & Production Well Flow Rate & gpm/well & 332 & & & & & \\
\hline & Temperature Drawdown Rate & \%/year & $15.0 \%$ & & & & & \\
\hline & Annual O\&M non-labor & $\%$ & $1.5 \%$ & & & & & \\
\hline & Number of O\&M staff & \# & 16.3 & & & & & \\
\hline \multirow{12}{*}{$\begin{array}{l}\text { TIO 2-Improve } \\
\text { fracture methods, } \\
\text { proppants and } \\
\text { rheology }\end{array}$} & Utilization Factor & $\%$ & $90 \%$ & & & & & \\
\hline & Brine Effectiveness & W-h/lb & 16.28 & & & & & \\
\hline & Plant Cost & $\$ / \mathrm{kW}$ & 940 & & & & & \\
\hline & Production Well Cost & SK/well & 12,530 & & & & & \\
\hline & Injector Well Cost & \$K/well & 12,530 & & & & & \\
\hline & $\begin{array}{l}\text { Surface Equipment Cost } \\
\text { Exploration Success }\end{array}$ & \$K/well & 100 & & & & 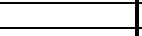 & 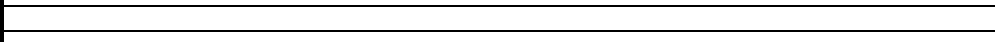 \\
\hline & \begin{tabular}{|l} 
Exploration Success \\
Confirmation Success
\end{tabular} & $\frac{R_{\text {Ratio }}}{\text { Ratio }}$ & 0.80 & & & & & Assumed that this EGS TIO impacts the EGS Flash case at $25 \%$ of the EGS Binary case. \\
\hline & Stimulation Cost & \$K/well & 750 & $-8.8 \%$ & $00 \%$ & $12.5 \%$ & $60 \%$ & $\begin{array}{l}\text { Driven by petroleum industry. \% improvement likely to be very small in } 2010 \text { time frame. Might lead to more } \\
\text { Dexpensive fruds and }\end{array}$ \\
\hline & Production Well Flow Rate & gpm/well & 700 & $8.8 \%$ & $0.0 \%$ & $12.5 \%$ & (100\% & 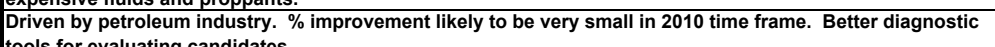 \\
\hline & Temperature Drawdown Rate & \% & & & & & & \\
\hline & \begin{tabular}{|l|l} 
Temperature Lrawaown Kate \\
Annual O\&M non-labor
\end{tabular} & \%olye & $\frac{15.0 \%}{1.5 \%}$ & & & & & +5 \\
\hline & Number of O\&M staff & \# & 1.070 & & & & & \\
\hline \multirow{13}{*}{$\begin{array}{l}\text { TIO 3-Control of } \\
\text { fracturing - new and } \\
\text { improved borehole } \\
\text { packers }\end{array}$} & Utilization Factor & $\%$ & $90 \%$ & & & & & \\
\hline & Brine Effectiveness & W-h/lb & 16.28 & & & & & \\
\hline & \begin{tabular}{|l|l|l} 
Plant Cost \\
Plantess
\end{tabular} & $\$ / \mathrm{kW}$ & $\frac{10.20}{940}$ & & & & & \\
\hline & Production Well Cost & SK/well & 12,530 & & & & & \\
\hline & Injector Well Cost & SK/well & 12,530 & & & & & \\
\hline & Surface Equipment Cost & \$K/well & $\frac{100}{100}$ & & & & & \\
\hline & Exploration Success & Ratio & 0.80 & & & & & \\
\hline & \begin{tabular}{|l|l} 
Lenfirmation Success \\
\end{tabular} & Ratio & 0.80 & & & & & Assumed that this EGS TIO impacts the EGS Flash case at $25 \%$ of the EGS Binary case. \\
\hline & Stimulation cost & SK/well & 750 & $-6.3 \%$ & $0.0 \%$ & $6.3 \%$ & $10 \%$ & Uncertain whether there would be a reduction of materials and equipment \\
\hline & \begin{tabular}{|l|l|l|l} 
Production Well Flow Rate \\
\end{tabular} & $\mathrm{gpm} / \mathrm{well}$ & 332 & $2.5 \%$ & $4.4 \%$ & $8.8 \%$ & $25 \%$ & More effective fracture placement \\
\hline & Temperature Drawdown Rate & \%/year & $15.0 \%$ & & & & & \\
\hline & Annual O\&M non-labor & $\%$ & $1.5 \%$ & & & & & \\
\hline & Number of O\&M staff & \# & 16.3 & & & & & \\
\hline \multirow{13}{*}{$\begin{array}{l}\text { TIO 4- Develop } \\
\text { numerical models } \\
\text { that accurately } \\
\text { predict fracture } \\
\text { growth and } \\
\text { permeability } \\
\text { development }\end{array}$} & Utilization Factor & $\%$ & $90 \%$ & & & & & \\
\hline & Brine Effectiveness & W-h/lb & 16.28 & & & & & \\
\hline & Plant Cost & $\$ / \mathrm{kW}$ & 940 & & & & & \\
\hline & Production Well Cost & SK/well & 12,530 & & & & & \\
\hline & Injector Well Cost & SK/well & 12,530 & & & & & \\
\hline & Surface Equipment Cost & 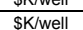 & 100 & & & & & \\
\hline & Exploration Success & Ration & 0.80 & & & & & \\
\hline & \begin{tabular}{|l|l} 
Confirmation Success \\
\end{tabular} & Ratio & 0.80 & & & & & Assumed that this EGS TIO impacts the EGS Flash case at $100 \%$ of the EGS Binary case. \\
\hline & Stimulation Cost & SKkiwell & $\frac{0.00}{750}$ & $-20.0 \%$ & $10.0 \%$ & $30.0 \%$ & $10 \% \mathrm{t}$ & HHP and Materials may Increase or Decrease \\
\hline & Production Well Flow Rate & $\mathrm{gpm} / \mathrm{well}$ & 332 & $10.0 \%$ & $25.0 \%$ & $50.0 \%$ & $70 \%$ & More effective fracture optimization \\
\hline & Temperature Drawdown Rate & \%/year & $15.0 \%$ & $\frac{10.0 \%}{4.0 \%}$ & $10.0 \%$ & $15.0 \%$ & $40 \%$ & Haven't been able to do the testing to see if models match reality \\
\hline & Annual O\&M non-labor & $\%$ & $1.5 \%$ & & & & & \\
\hline & Number of O\&M staff & \# & 16.3 & & & & & \\
\hline
\end{tabular}




\begin{tabular}{|c|c|c|c|c|c|c|c|c|}
\hline \multirow[b]{3}{*}{ TIO Categories } & \multirow[b]{3}{*}{ GETEM INPUTS/TPMs } & \multicolumn{7}{|c|}{ EGS FLASH 2010- SYSTEM SCORING SHEET } \\
\hline & & \multirow[b]{2}{*}{ Units } & \multirow{2}{*}{\begin{tabular}{|l|} 
Baseline \\
in 2005
\end{tabular}} & \multicolumn{3}{|c|}{ TIO Improvements in 2010 in \% } & \multirow{2}{*}{$\begin{array}{c}\text { Prob. of } \\
\text { Success \% }\end{array}$} & \multirow[b]{2}{*}{ Comments } \\
\hline & & & & Minimum \% & Expected \% & Maximum \% & & \\
\hline \multirow{12}{*}{$\begin{array}{l}\text { TIO 5- Ability to } \\
\text { create a subsurface } \\
\text { circulation system } \\
\text { as designed }\end{array}$} & \begin{tabular}{|l} 
Utilization Factor \\
tilats \\
\end{tabular} & $\%$ & $90 \%$ & & & & & \\
\hline & Brine Effectiveness & W-h/lb & 16.28 & & & & & \\
\hline & Plant Cost & S/kW & 940 & & & & & \\
\hline & Production Well Cost & \$K/well & 12,530 & & & & & \\
\hline & Injector Well Cost & \$K/well & 12,530 & & & & & \\
\hline & Surface Equipment Cost & \$K/well & $\begin{array}{r}100 \\
080\end{array}$ & & & & & \\
\hline & \begin{tabular}{|l|} 
Exploration Success \\
Confirmation Success
\end{tabular} & 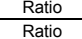 & $\begin{array}{l}0.80 \\
0.80\end{array}$ & & & & & 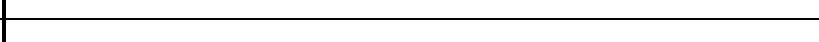 \\
\hline & Stimulation Cost & SK/well & 750 & $-2.5 \%$ & $7.3 \%$ & $12.5 \%$ & $20 \%$ & Assumed that this EGS TIO impacts the EGS Flash case at $25 \%$ of the EGS Binary case. \\
\hline & Production Well Flow Rate & gpm/well & 332 & & & & & \\
\hline & Temperature Drawdown Rate & \%/year & $15.0 \%$ & $1.3 \%$ & $7.3 \%$ & $18.8 \%$ & $20 \%$ & Assumed that this EGS TIO impacts the EGS Flash case at $25 \%$ of the EGS Binary case. \\
\hline & Annual O\&M non-labor & $\%$ & $1.5 \%$ & & & & & \\
\hline & Number of O\&M staff & $\#$ & 16.3 & & & & & \\
\hline \multirow{13}{*}{$\begin{array}{l}\text { TIO 6- Develop } \\
\text { numerical models } \\
\text { that explain and } \\
\text { extend reservoir } \\
\text { performance }\end{array}$} & Utilization Factor & $\%$ & $90 \%$ & & & & & \\
\hline & Brine Effectiveness & W-h/lb & 16.28 & & & & & \\
\hline & Plant Cost & S/kW & 940 & & & & & \\
\hline & Production Well Cost & \$K/well & 12,530 & & & & & \\
\hline & Injector Well Cost & \$K/well & 12,530 & & & & & \\
\hline & Surface Equipment Cost & \$K/well & $\frac{100}{080}$ & & & & & \\
\hline & Exploration Success & Ratio & 0.80 & & & & & \\
\hline & Confirmation Success & Ratio & 0.80 & & & & & \\
\hline & Stimulation Cost & \$K/well & 750 & & & & & \\
\hline & Production Well Flow Rate & gpm/well & 332 & & & & & \\
\hline & Temperature Drawdown Rate & \%/year & $15.0 \%$ & $5.0 \%$ & $10.0 \%$ & $20.0 \%$ & $30 \%$ & Assumed that this EGS TIO impacts the EGS Flash case at $100 \%$ of the EGS Binary case. \\
\hline & Annual O\&M non-labor & $\%$ & $1.5 \%$ & & & & & \\
\hline & Number of O\&M staff & $\#$ & 16.3 & & & & & \\
\hline \multirow{13}{*}{\begin{tabular}{|} 
TIO 7-Improve \\
artificial lift \\
technology
\end{tabular}} & \begin{tabular}{|l} 
Utilization Factor \\
\end{tabular} & $\%$ & $90 \%$ & & & & & \\
\hline & Brine Effectiveness & W-h/lb & 16.28 & & & & & \\
\hline & Plant Cost & $\$ / k W$ & 940 & & & & & \\
\hline & Production Well Cost & \$K/well & 12,530 & & & & & \\
\hline & Injector Well Cost & \$K/well & 12,530 & & & & & \\
\hline & Surface Equipment Cost & \$K/well & 100 & & & & & \\
\hline & \begin{tabular}{|l} 
Exploration Success \\
\end{tabular} & Ratio & 0.80 & & & & & \\
\hline & \begin{tabular}{|l|} 
Confirmation Success \\
\end{tabular} & Ratio & 0.80 & & & & & \\
\hline & Stimulation Cost & \$K/well & 750 & & & & & \\
\hline & Production Well Flow Rate & gpm/well & 332 & $1.0 \%$ & $50.0 \%$ & $100.0 \%$ & $5 \%$ & \\
\hline & Temperature Drawdown Rate & \%/year & $15.0 \%$ & & & & & \\
\hline & Annual O\&M non-labor & $\%$ & $1.5 \%$ & & & & & \\
\hline & Number of O\&M staff & \# & 16.3 & & & & & \\
\hline \multirow{13}{*}{$\begin{array}{l}\text { TIO 8- Improve short } \\
\text { circuit mitigation } \\
\text { methods }\end{array}$} & \begin{tabular}{|l} 
Utilization Factor \\
\end{tabular} & $\%$ & $90 \%$ & & & & & \\
\hline & Brine Effectiveness & W-h/lb & 16.28 & & & & & \\
\hline & Plant Cost & $\$ / k W$ & 940 & & & & & \\
\hline & Production Well Cost & \$K/well & 12,530 & & & & & \\
\hline & Injector Well Cost & \$K/well & 12,530 & & & & & \\
\hline & Surface Equipment Cost & \$K/well & 100 & & & & & \\
\hline & \begin{tabular}{|l} 
Exploration Success \\
\end{tabular} & Ratio & 0.80 & & & & & \\
\hline & \begin{tabular}{|l} 
Confirmation Success \\
\end{tabular} & Ratio & 0.80 & & & & & \\
\hline & Stimulation Cost & \$K/well & 750 & $1.0 \%$ & $12.5 \%$ & $25.0 \%$ & $10 \%$ & \\
\hline & Production Well Flow Rate & gpm/well & 332 & $1.0 \%$ & $12.5 \%$ & $25.0 \%$ & $10 \%$ & Assumed that this EGS TIO impacts the EGS Flash case at $25 \%$ of the EGS Binary case. \\
\hline & Temperature Drawdown Rate & \%/year & $15.0 \%$ & & & & & \\
\hline & \begin{tabular}{|l|l} 
Annual O\&M non-labor \\
\end{tabular} & $\%$ & $1.5 \%$ & & & & & \\
\hline & Number of O\&M staff & \# & 16.3 & & & & & \\
\hline
\end{tabular}




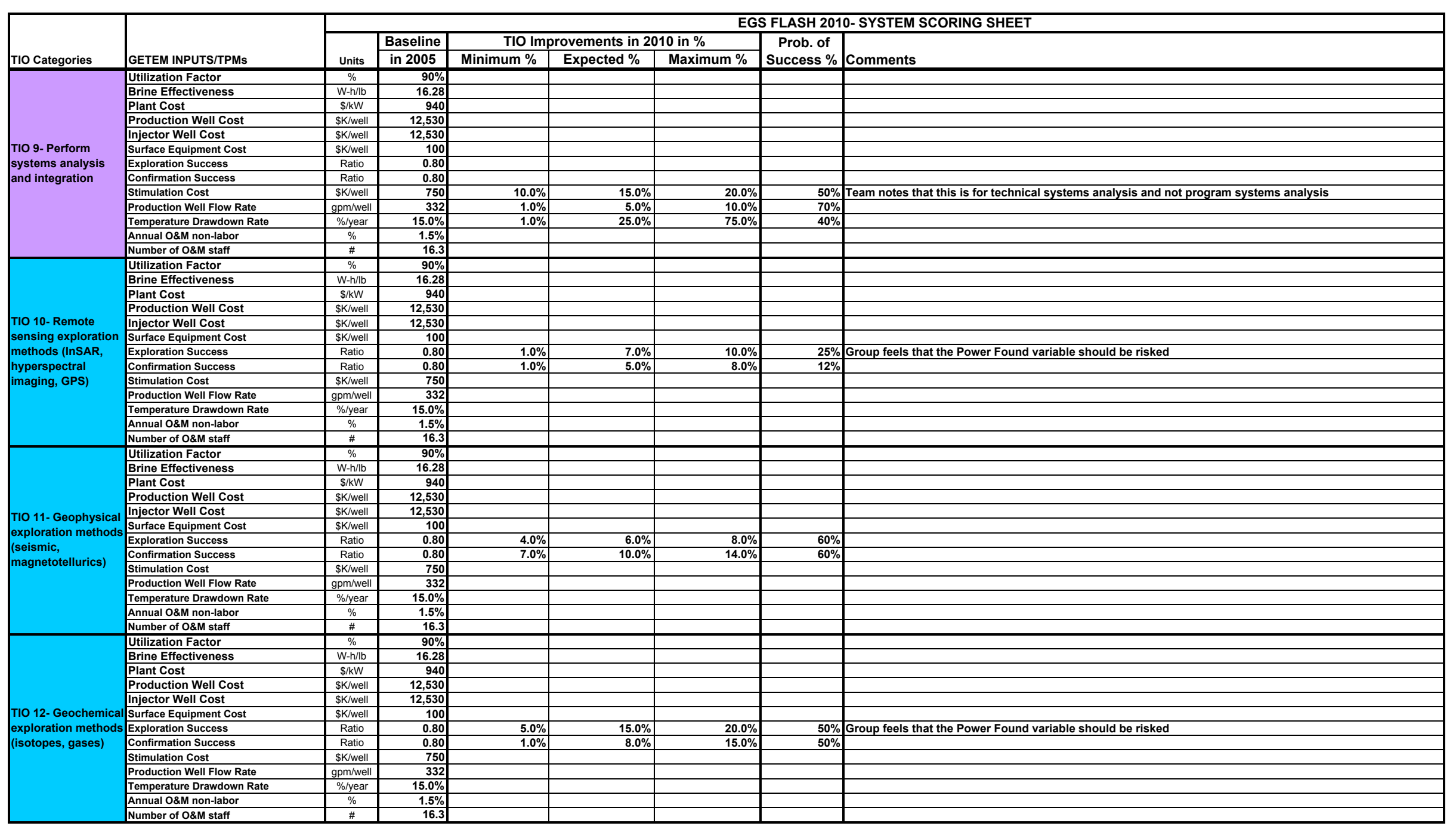




\begin{tabular}{|c|c|c|c|c|c|c|c|c|}
\hline \multirow[b]{3}{*}{ TIO Categories } & \multirow[b]{3}{*}{ GETEM INPUTS/TPMs } & \multicolumn{7}{|c|}{ EGS FLASH 2010- SYSTEM SCORING SHEET } \\
\hline & & \multirow[b]{2}{*}{ Units } & \multirow{2}{*}{$\begin{array}{c}\text { Baseline } \\
\text { in } 2005\end{array}$} & \multicolumn{3}{|c|}{ TIO Improvements in 2010 in \% } & \multirow{2}{*}{$\begin{array}{c}\text { Prob. of } \\
\text { Success } \%\end{array}$} & \multirow[b]{2}{*}{ Comments } \\
\hline & & & & Minimum \% & Expected \% & Maximum \% & & \\
\hline \multirow{12}{*}{$\begin{array}{l}\text { TIO 13- National } \\
\text { geothermal } \\
\text { assessment and } \\
\text { supply (ES, } \\
\text { hydrothermal) }\end{array}$} & Utilization Factor & $\%$ & $90 \%$ & & & & & \\
\hline & \begin{tabular}{|l|} 
Brine Effectiveness \\
Plant Cost
\end{tabular} & $\frac{W-h / l b}{S / k W}$ & $\begin{array}{r}16.28 \\
940\end{array}$ & & & & & \\
\hline & \begin{tabular}{|l|} 
Production Well Cost \\
\end{tabular} & SK/well & 12,530 & & & & & \\
\hline & Injector Well Cost & SK/well & 12,530 & & & & & \\
\hline & Surface Equipment Cost & \$K/well & 100 & & & & & \\
\hline & Exploration Success & Ratio & 0.80 & & & & & $\begin{array}{l}\text { Really an enabling TIO that allows the other improvements to be made. Needs to be done to support or } \\
\text { condemn the program. Industry has been pushing for this (thinking that it would be the program going out } \\
\text { and actually drilling wells). }\end{array}$ \\
\hline & Confirmation Success & Ratio & 0.80 & & & & & \\
\hline & \begin{tabular}{|l|l} 
Stimulation Cost \\
\end{tabular} & SK/well & 750 & & & & & \\
\hline & \begin{tabular}{|l|} 
Production Well Flow Rate \\
\end{tabular} & $\mathrm{gpm} / \mathrm{well}$ & 332 & & & & & \\
\hline & Temperature Drawdown Rate & \%/year & $15.0 \%$ & & & & & \\
\hline & Annual O\&M non-labor & $\%$ & $1.5 \%$ & & & & & \\
\hline & Number of O\&M staff & \# & \begin{tabular}{l|l}
$0.0 \%$ \\
16.3 \\
\end{tabular} & & & & & \\
\hline \multirow{12}{*}{$\begin{array}{l}\text { TIO 14- Reduction of } \\
\text { drilling time and } \\
\text { expense, especially } \\
\text { in hard abrasive } \\
\text { formations }\end{array}$} & \begin{tabular}{|l} 
Utilization Factor \\
\end{tabular} & $\%$ & $90 \%$ & & & & & \\
\hline & \begin{tabular}{|l|} 
Brine Effectiveness \\
Plant Cost
\end{tabular} & $\begin{array}{ll}W-h / b \\
S / k W\end{array}$ & \begin{tabular}{r|r|}
16.28 \\
940
\end{tabular} & & & & & \\
\hline & Production Well Cost & SK/well & $\begin{array}{r}940 \\
12,530\end{array}$ & $5.0 \%$ & $12.0 \%$ & $20.0 \%$ & $65 \%$ & Experts assumed this TIO would impact the EGS Flash case the same as the EGS Binary case. \\
\hline & injector Well Cost & 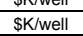 & 12,530 & $5.0 \%$ & $12.0 \%$ & $20.0 \%$ & $65 \%$ & $\begin{array}{l}\text { Experts assumed this TIO would impact the EGS Flash case the same as the EGS Binary case. } \\
\text {. }\end{array}$ \\
\hline & Surface Equipment Cost & SK/well & 100 & & & & & \\
\hline & Exploration Success & Ratio & 0.80 & & & & & \\
\hline & Confirmation Success & Ratio & 0.80 & & & & & \\
\hline & Stimulation Cost & \$K/well & 750 & & & & & \\
\hline & Production Well Flow Rate & $\mathrm{gpm} / \mathrm{well}$ & 332 & & & & & \\
\hline & Temperature Drawdown Rate & $\% / y e a r$ & $15.0 \%$ & & & & & \\
\hline & \begin{tabular}{|l|l} 
Annual O\&M non-labor \\
\end{tabular} & $\%$ & $1.5 \%$ & & & & & \\
\hline & Number of O\&M staff & \# & 1..3.3 & & & & & \\
\hline \multirow{12}{*}{\begin{tabular}{|l} 
TIO 15- Reduction \\
time and expense to \\
line the wellbore \\
(including using less \\
material and less \\
costly material)
\end{tabular}} & Utilization Factor & $\%$ & $90 \%$ & & & & & \\
\hline & \begin{tabular}{|l|} 
Brine Effectiveness \\
Plant Cost
\end{tabular} & $\frac{W-h / l b}{S / k W}$ & $\begin{aligned} 16.28 \\
940\end{aligned}$ & & & & & \\
\hline & Production Well Cost & \$K/well & 12,530 & $6.0 \%$ & $13.0 \%$ & $18.0 \%$ & $50 \%$ & $\begin{array}{l}\text { One expert thought that "robust hard rock under-reamer for use with expandable tubular casing, casing } \\
\text { drilling, minimum clearance casing design" is not a long range process to develop and it is in the MYPP, but it } \\
\text { is not currently being funded. }\end{array}$ \\
\hline & Injector Well Cost & SK/well & 12,530 & $6.0 \%$ & $13.0 \%$ & $18.0 \%$ & $50 \%$ & Experts assumed this TIO would impact the EGS Flash case the same as the EGS Binary case. \\
\hline & Surface Equipment Cost & SK/well & 100 & & & & & \\
\hline & Exploration Success & Ratio & 0.80 & & & & & \\
\hline & Confirmation Success & Ratio & 0.80 & & & & & \\
\hline & Stimulation Cost & \$K/well & 750 & & & & & \\
\hline & Production Well Flow Rate & gpm/well & 332 & & & & & \\
\hline & Temperature Drawdown Rate & \%/year & $15.0 \%$ & & & & & \\
\hline & \begin{tabular}{|l|l} 
Annual O\&M non-labor \\
\end{tabular} & $\%$ & $1.5 \%$ & & & & & \\
\hline & Anumber of O\&M Staff & \# & $\frac{1.0 \%}{16.3}$ & & & & & \\
\hline \multirow{12}{*}{$\begin{array}{l}\text { TIO 16- Reduction of } \\
\text { non-essential flat } \\
\text { time }\end{array}$} & \begin{tabular}{|l|} 
Utilization Factor \\
Brine Fffectiveness
\end{tabular} & $\%$ & \begin{tabular}{r|r}
$90 \%$ \\
1628
\end{tabular} & & & & & \\
\hline & \begin{tabular}{|l} 
Brine Effectiveness \\
Plant Cost
\end{tabular} & $\frac{\mathrm{W}-\mathrm{hll} / \mathrm{G}}{\Phi / \mathrm{k} W}$ & $\begin{array}{r}16.28 \\
940\end{array}$ & & & & & \\
\hline & Production Well Cost & SK/well & 12,530 & $2.0 \%$ & $4.0 \%$ & $10.0 \%$ & $50 \%$ & Experts assumed this TIO would impact the EGS Flash case the same as the EGS Binary case. \\
\hline & Injector Well Cost & SK/well & 12,530 & $2.0 \%$ & $4.0 \%$ & $10.0 \%$ & $50 \%$ & Experts assumed this TIO would impact the EGS Flash case the same as the EGS Binary case. \\
\hline & Surface Equipment Cost & SK/well & 100 & & & & & \\
\hline & Exploration Success & Ratio & 0.80 & & & & & \\
\hline & Confirmation Success & Ratio & 0.80 & & & & & \\
\hline & Stimulation Cost & \$K/well & 750 & & & & & \\
\hline & Production Well Flow Rate & $\mathrm{gpm} / \mathrm{well}$ & 332 & & & & & \\
\hline & Temperature Drawdown Rate & \%/year & $15.0 \%$ & & & & & \\
\hline & Annual O\&M non-labor & $\%$ & $1.5 \%$ & & & & & \\
\hline & Number of O\&M staff & \# & 16.3 & & & & & \\
\hline
\end{tabular}




\begin{tabular}{|c|c|c|c|c|c|c|c|c|}
\hline \multirow[b]{3}{*}{ TIO Categories } & \multirow[b]{3}{*}{ GETEM INPUTS/TPMs } & \multicolumn{7}{|c|}{ EGS FLASH 2010-SYSTEM SCORING SHEET } \\
\hline & & \multirow[b]{2}{*}{ Units } & \multirow{2}{*}{$\begin{array}{l}\text { Baseline } \\
\text { in } 2005\end{array}$} & \multicolumn{3}{|c|}{ TIO Improvements in 2010 in \% } & \multirow{2}{*}{$\begin{array}{c}\text { Prob. of } \\
\text { Success \% }\end{array}$} & \multirow[b]{2}{*}{ Comments } \\
\hline & & & & Minimum \% & Expected \% & Maximum \% & & \\
\hline \multirow{13}{*}{$\begin{array}{l}\text { TIO 17- Development } \\
\text { of basic information } \\
\text { through analysis } \\
\text { and simulation } \\
\text { efforts. }\end{array}$} & \begin{tabular}{|l|l} 
Utilization Factor \\
\end{tabular} & $\%$ & & & & & & \\
\hline & Brine Effectiveness & W-h/lb & 16.28 & & & & & \\
\hline & Plant Cost & $\$ / \mathrm{kW}$ & 940 & & & & & \\
\hline & Production Well Cost & SK/well & 12,530 & $4.0 \%$ & $8.0 \%$ & $12.0 \%$ & $75 \%$ & Experts assumed this TIO would impact the EGS Flash case the same as the EGS Binary case. \\
\hline & Injector Well Cost & \$K/well & 12,530 & $4.0 \%$ & $8.0 \%$ & $12.0 \%$ & $75 \%$ & Experts assumed this TIO would impact the EGS Flash case the same as the EGS Binary case. \\
\hline & Surface Equipment Cost & \$K/well & 100 & 4.0 & 0.0 & 12.0\% & (15\% & 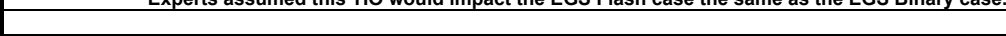 \\
\hline & Exploration Success & Ratio & 0.80 & & & & & \\
\hline & Confirmation Success & Ratio & 0.80 & & & & & \\
\hline & Stimulation Cost & SK/well & 750 & & & & & \\
\hline & Production Well Flow Rate & $\mathrm{gpm} / \mathrm{well}$ & 332 & & & & & \\
\hline & Temperature Drawdown Rate & \%/year & $15.0 \%$ & & & & & \\
\hline & Annual O\&M non-labor & $\%$ & $1.5 \%$ & & & & & \\
\hline & Number of O\&M staff & $\#$ & 16.3 & & & & & \\
\hline \multirow{13}{*}{$\begin{array}{l}\text { TIO 18-Completion } \\
\text { and production } \\
\text { related development } \\
\text { projects }\end{array}$} & \begin{tabular}{|l} 
Utilization Factor \\
\end{tabular} & $\%$ & $90 \%$ & & & & & \\
\hline & \begin{tabular}{|l|} 
Brine Effectiveness \\
\end{tabular} & W-h/llb & 16.28 & & & & & \\
\hline & \begin{tabular}{|l} 
Plant Cost \\
\end{tabular} & $\$ / k W$ & 940 & & & & & \\
\hline & Production Well Cost & SK/well & 12,530 & $2.0 \%$ & $3.5 \%$ & $6.0 \%$ & $60 \%$ & \\
\hline & Injector Well Cost & SK/well & 12,530 & $2.0 \%$ & $3.5 \%$ & $6.0 \%$ & $60 \%$ & \\
\hline & Surface Equipment Cost & SK/well & 100 & & & & & \\
\hline & Exploration Success & $\begin{array}{l}\text { SNweit } \\
\text { Ratio } \\
\end{array}$ & 0.80 & & & & & \\
\hline & \begin{tabular}{|c|} 
Confirmation Success \\
\end{tabular} & Ratio & 0.80 & & & & & \\
\hline & Stimulation Cost & \$K/well & 750 & & & & & \\
\hline & Production Well Flow Rate & gpm/well & 332 & & & & & \\
\hline & Temperature Drawdown Rate & \%/year & $15.0 \%$ & & & & & \\
\hline & Annual O\&M non-labor & $\%$ & $1.5 \%$ & & & & & $\begin{array}{l}\text { One expert thought this TIO might have a small impact on fields in terms of life cycle costs, with the exception } \\
\text { of very corrosive or very hot fields. }\end{array}$ \\
\hline & Number of O\&M staff & \# & 16.3 & & & & & \\
\hline \multirow{13}{*}{$\begin{array}{l}\text { TiO 19-Cycle } \\
\text { Related }\end{array}$} & Utilization Factor & $\%$ & $90 \%$ & $1.0 \%$ & $3.0 \%$ & $4.0 \%$ & $90 \%$ & Experts assumed the same improvements and probabilities as the hydrothermal flash 2010 case. \\
\hline & Brine Effectiveness & W-h-hlb & 16.28 & $1.0 \%$ & $5.0 \%$ & $10.0 \%$ & $90 \%$ & Experts assumed the same improvements and probabilities as the hydrothermal flash 2010 case. \\
\hline & Plant Cost & S/kW & 940 & & & & & \\
\hline & Production Well Cost & SK/well & 12,530 & & & & & \\
\hline & Injector Well Cost & \$K/well & 12,530 & & & & & \\
\hline & Surface Equipment Cost & \$K/well & 100 & & & & & \\
\hline & Exploration Success & Ratio & 0.80 & & & & & \\
\hline & Confirmation Success & Ratio & 0.80 & & & & & \\
\hline & Stimulation Cost & SK/well & 750 & & & & & \\
\hline & Production Well Flow Rate & gpm/well & 332 & & & & & \\
\hline & Temperature Drawdown Rate & \%/year & $15.0 \%$ & & & & & \\
\hline & Annual O\&M non-labor & $\%$ & $1.5 \%$ & & & & & \\
\hline & Number of O\&M staff & \# & 16.3. & & & & & \\
\hline \multirow{12}{*}{$\begin{array}{l}\text { TIO 20-Component } \\
\text { Related }\end{array}$} & Utilization Factor & $\%$ & $90 \%$ & $1.0 \%$ & $3.0 \%$ & $5.0 \%$ & $80 \%$ & Experts assumed the same improvements and probabilities as the hydrothermal flash 2010 case. \\
\hline & \begin{tabular}{|l|l} 
Brine Effectiveness \\
\end{tabular} & W-hl/lb & 16.28 & $2.3 \%$ & $6.7 \%$ & $10.0 \%$ & $70 \%$ & Experts assumed the same improvements and probabilities as the hydrothermal flash 2010 case. \\
\hline & Plant Cost & $\$ / \mathrm{kW}$ & 940 & & & & & \\
\hline & Production Well Cost & SK/well & 12,530 & & & & & \\
\hline & Injector Well Cost & \$K/well & 12,530 & & & & & \\
\hline & Surface Equipment Cost & \$K/well & 100 & & & & & \\
\hline & Exploration Success & Ratio & 0.80 & & & & & \\
\hline & Confirmation Success & Ratio & 0.80 & & & & & \\
\hline & Stimulation Cost & SK/well & 750 & & & & & \\
\hline & \begin{tabular}{|l|} 
Production Well Ilow Rate \\
Temperature Drawdown Rate
\end{tabular} & 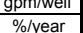 & $\frac{352}{15.0 \%}$ & & & & & \\
\hline & Annual O\&M non-labor & $\%$ & $1.5 \%$ & & & & & \\
\hline & Number of O\&M staff & $\#$ & 16.3 & & & & & \\
\hline
\end{tabular}




\begin{tabular}{|c|c|c|c|c|c|c|c|c|}
\hline \multirow[b]{3}{*}{ TIO Categories } & \multirow[b]{3}{*}{ GETEM INPUTS/TPMS } & \multicolumn{7}{|c|}{ EGS FLASH 2010-SYSTEM SCORING SHEET } \\
\hline & & \multirow[b]{2}{*}{ Units } & \multirow{2}{*}{$\begin{array}{c}\text { Baseline } \\
\text { in } 2005\end{array}$} & \multicolumn{3}{|c|}{ TIO Improvements in 2010 in \% } & \multirow{2}{*}{$\begin{array}{c}\text { Prob. of } \\
\text { Success \% }\end{array}$} & \multirow[b]{2}{*}{ Comments } \\
\hline & & & & Minimum \% & Expected \% & Maximum \% & & \\
\hline \multirow{12}{*}{$\begin{array}{l}\text { TIO 21- Monitoring \& } \\
\text { Scaling }\end{array}$} & \begin{tabular}{|l} 
Utilization Factor \\
til
\end{tabular} & $\%$ & & & & & & \\
\hline & Brine Effectiveness & W-h/lb & 16.28 & $0.3 \%$ & $3.3 \%$ & $6.7 \%$ & $60 \%$ & Experts assumed the same improvements and probabilities as the hydrothermal flash 2010 case. \\
\hline & Plant Cost & $\$ / \mathrm{kW}$ & 940 & & & & & \\
\hline & Production Well Cost & \$K/well & 12,530 & & & & & \\
\hline & Injector Well Cost & \$K/well & 12,530 & & & & & \\
\hline & \begin{tabular}{|l} 
Surface Equipment Cost \\
Exploration Success
\end{tabular} & \$K/well & 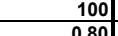 & & & & & \\
\hline & Confirmation Success & $\frac{\text { Ratio }}{\text { Ratio }}$ & $\frac{0.80}{0.80}$ & 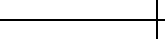 & & & & \\
\hline & Stimulation Cost & SK/well & $\frac{0.00}{750}$ & & & & & \\
\hline & Production Well Flow Rate & gpm/well & 332 & & & & & \\
\hline & Temperature Drawdown Rate & \%/year & $15.0 \%$ & & & & & \\
\hline & Annual O\&M non-labor & $\%$ & $1.5 \%$ & $3.0 \%$ & $16.3 \%$ & $26.8 \%$ & $70 \%$ & Experts assumed the same improvements and probabilities as the hydrothermal flash 2010 case. \\
\hline & Number of O\&M staff & \# & 16.3 & & & & & \\
\hline \multirow{13}{*}{$\begin{array}{l}\text { TIO 22- } \\
\text { Design/Construction } \\
\text { Related }\end{array}$} & Utilization Factor & $\%$ & $90 \%$ & & & & & \\
\hline & Brine Effectiveness & W-h/lb & 16.28 & & & & & \\
\hline & Plant Cost & $\$ \mathrm{~s} / \mathrm{kW}$ & 940 & $8.3 \%$ & $18.3 \%$ & $25.0 \%$ & $80 \%$ & Experts assumed the same improvements and probabilities as the hydrothermal flash 2010 case. \\
\hline & Production Well Cost & \$K/well & 12,530 & & & & & \\
\hline & Injector Well Cost & SK/well & 12,530 & & & & & \\
\hline & Surface Equipment Cost & SK/well & 100 & & & & & \\
\hline & Exploration Success & Ratio & 0.80 & & & & & \\
\hline & Confirmation Success & Ratio & 0.80 & & & & & \\
\hline & Stimulation Cost & SK/well & 750 & & & & & \\
\hline & Production Well Flow Rate & gpm/well & 332 & & & & & \\
\hline & Temperature Drawdown Rate & \%/year & $15.0 \%$ & & & & & \\
\hline & Annual O\&M non-labor & $\%$ & $1.5 \%$ & $5.0 \%$ & $10.0 \%$ & $15.0 \%$ & $80 \%$ & Experts assumed the same improvements and probabilities as the hydrothermal flash 2010 case. \\
\hline & Number of O\&M staff & \# & 16.3 & & & & & \\
\hline \multirow{13}{*}{$\begin{array}{l}\text { TIO 23- } \\
\text { Automation/Enhance } \\
\text { d Controls }\end{array}$} & Utilization Factor & $\%$ & $90 \%$ & & & & & \\
\hline & Brine Effectiveness & W-h/lb & 16.28 & $1.3 \%$ & $2.5 \%$ & 4.0\% & $50 \%$ & Experts assumed the same improvements and probabilities as the hydrothermal flash 2010 case. \\
\hline & Plant Cost & $\$ / k W$ & 940 & & & & & \\
\hline & Production Well Cost & \$K/well & 12,530 & & & & & \\
\hline & Injector Well Cost & \$K/well & 12,530 & & & & & \\
\hline & Surface Equipment Cost & SK/well & 100 & & & & & \\
\hline & Exploration Success & Ratio & 0.80 & & & & & \\
\hline & Confirmation Success & Ratio & 0.80 & & & & & \\
\hline & Stimulation Cost & \$K/well & 750 & & & & & \\
\hline & \begin{tabular}{|l} 
Production Well Flow Rate \\
\end{tabular} & $\mathrm{gpm} / \mathrm{well}$ & 332 & & & & & \\
\hline & Temperature Drawdown Rate & \%/year & $15.0 \%$ & & & & & \\
\hline & \begin{tabular}{|l|l|l} 
Annual O\&M non-labor \\
\end{tabular} & $\%$ & $1.5 \%$ & $5.5 \%$ & $10.0 \%$ & $15.0 \%$ & $80 \%$ & Experts assumed the same improvements and probabilities as the hydrothermal flash 2010 case. \\
\hline & Number of O\&M staff & $\#$ & 16.3 & $20.0 \%$ & $40.0 \%$ & $50.0 \%$ & $80 \%$ & Experts assumed the same improvements and probabilities as the hydrothermal flash 2010 case. \\
\hline \multirow{13}{*}{ Sum of TIOs } & Utilization Factor & $\%$ & $90 \%$ & $2.0 \%$ & $6.0 \%$ & $9.0 \%$ & $85 \%$ & $\begin{array}{l}\text { Cap value at } 100 \% \text { for Util Factor for combined impacts of TIO } 19,21,22 \text { and } 23 \text { (put if statements into model } \\
\text { to limit improvements to } 5 \% \text { increase from } 95 \% \text { baseline). TIO } 20 \text { can add to that and go over } 100 \% \text {. }\end{array}$ \\
\hline & Brine Effectiveness & W-h/lb & 16.28 & $4.9 \%$ & $17.5 \%$ & $30.7 \%$ & $68 \%$ & Cap value at $25 \%$ improvement \\
\hline & Plant Cost & $\$ / \mathrm{kW}$ & 940 & $8.3 \%$ & $18.3 \%$ & $25.0 \%$ & $80 \%$ & Cap value at $50 \%$ improvement \\
\hline & Production Well Cost & SK/well & 12,530 & $17.7 \%$ & $34.7 \%$ & $51.2 \%$ & $60 \%$ & Mulitplicative combination of \% improvements as per Chip Mansure suggestion \\
\hline & Injector Well Cost & SK/well & 12,530 & $17.7 \%$ & $34.7 \%$ & $51.2 \%$ & $60 \%$ & Mulitplicative combination of $\%$ improvements as per Chip Mansure suggestion \\
\hline & Surface Equipment Cost & SK/well & 100 & $0.0 \%$ & $0.0 \%$ & $0.0 \%$ & & \\
\hline & Exploration Success & Ratio & 0.80 & $11.0 \%$ & $33.0 \%$ & $45.0 \%$ & $56 \%$ & Cap value at $95 \%$, if it goes over limit, prorate new amount back to each TIO. \\
\hline & Confirmation Success & Ratio & 0.80 & $10.0 \%$ & $25.0 \%$ & $41.0 \%$ & $53 \%$ & Cap value at $95 \%$ if it goes over limit, prorate new amount back to each TIO. \\
\hline & Stimulation Cost & \$K/well & 750 & $-26.5 \%$ & 44.8\% & $106.3 \%$ & $27 \%$ & Cap value at $75 \%$ improvement \\
\hline & Production Well Flow Rate & gpm/well & 332 & $16.8 \%$ & $100.2 \%$ & $200.0 \%$ & $40 \%$ & \\
\hline & Temperature Drawdown Rate & \%/year & $15.0 \%$ & $11.3 \%$ & $52.3 \%$ & $128.8 \%$ & $33 \%$ & Cap value at $75 \%$ improvement \\
\hline & Annual O\&M non-labor & $\%$ & $1.5 \%$ & $13.5 \%$ & $36.3 \%$ & $56.8 \%$ & $77 \%$ & Cap value at $40 \%$ improvement \\
\hline & Number of O\&M staff & $\#$ & 16.3 & $20.0 \%$ & $40.0 \%$ & $50.0 \%$ & $80 \%$ & Cap value at $50 \%$ improvement \\
\hline
\end{tabular}




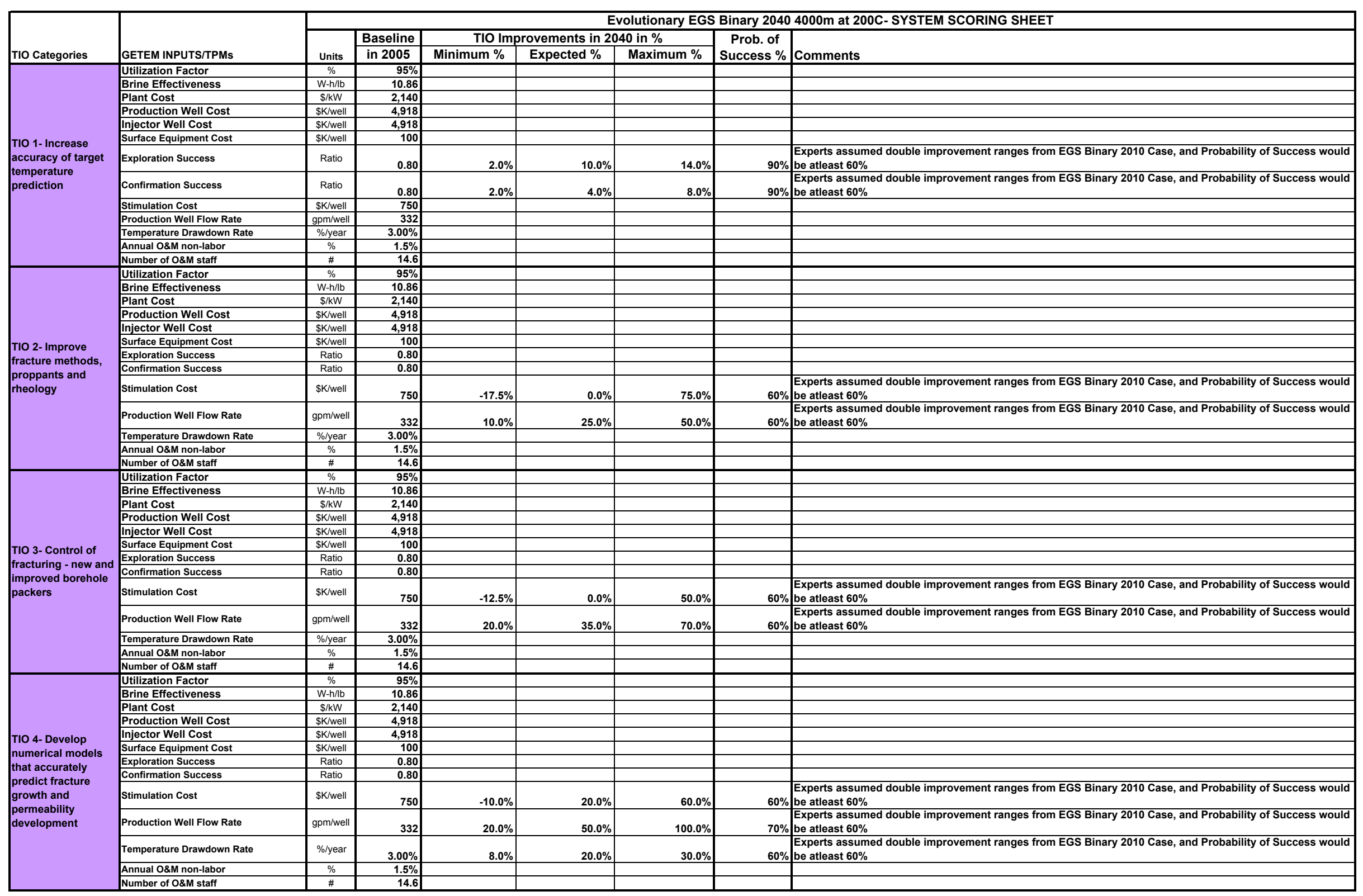




\begin{tabular}{|c|c|c|c|c|c|c|c|c|}
\hline \multirow[b]{3}{*}{ TIO Categories } & \multirow[b]{3}{*}{ GETEM INPUTS/TPMS } & \multicolumn{7}{|c|}{ Evolutionary EGS Binary $20404000 \mathrm{~m}$ at 200C-SYSTEM SCORING SHEET } \\
\hline & & \multirow[b]{2}{*}{ Units } & \multirow{2}{*}{\begin{tabular}{c|c} 
Baseline \\
in 2005 \\
\end{tabular}} & \multicolumn{3}{|c|}{ TIO Improvements in 2040 in \% } & \multirow{2}{*}{\begin{tabular}{|c|} 
Prob. of \\
Success \%
\end{tabular}} & \multirow[b]{2}{*}{ Comments } \\
\hline & & & & Minimum \% & Expected \% & Maximum \% & & \\
\hline \multirow{13}{*}{$\begin{array}{l}\text { TIO 5-Ability to } \\
\text { create a subsurface } \\
\text { circulation system } \\
\text { as designed }\end{array}$} & Utilization Factor & $\%$ & & & & & & \\
\hline & Brine Effectiveness & W-h/lb & 10.86 & & & & & \\
\hline & \begin{tabular}{|l|l|l|l|l} 
Plant Cost \\
\end{tabular} & $\$ / k W$ & 2,140 & & & & & \\
\hline & Production Well Cost & \$K/well & 4,918 & & & & & \\
\hline & Injector Well Cost & \$K/well & 4,918 & & & & & \\
\hline & Surface Equipment Cost & \$K/well & 100 & & & & & \\
\hline & \begin{tabular}{|l} 
Exploration Success \\
\end{tabular} & Ratio & 0.80 & & & & & \\
\hline & Confirmation Success & Ratio & 0.80 & & & & & \\
\hline & Stimulation Cost & \$K/well & 750 & $-5.0 \%$ & $60.0 \%$ & $75.0 \%$ & $60 \%$ & $\begin{array}{l}\text { Experts assumed double improvement ranges from EGS Binary } 2010 \text { Case, and Probability of Success would } \\
\text { be atleast } 60 \%\end{array}$ \\
\hline & \begin{tabular}{|l} 
Production Well Flow Rate \\
\end{tabular} & gpm/well & 332 & & & & & \\
\hline & Temperature Drawdown Rate & \%/year & $3.00 \%$ & $10.0 \%$ & $60.0 \%$ & $75.0 \%$ & $60 \%$ & $\begin{array}{l}\text { Experts assumed double improvement ranges from EGS Binary } 2010 \text { Case, and Probability of Success would } \\
\text { be atleast } 60 \%\end{array}$ \\
\hline & Annual O\&M non-labor & $\%$ & $1.5 \%$ & & & & & \\
\hline & Number of O\&M staff & \# & 14.6 & & & & & \\
\hline \multirow{13}{*}{$\begin{array}{l}\text { TIO 6- Develop } \\
\text { numerical models } \\
\text { that explain and } \\
\text { extend reservoir } \\
\text { performance }\end{array}$} & \begin{tabular}{|l} 
Utilization Factor \\
\end{tabular} & $\%$ & $95 \%$ & & & & & \\
\hline & \begin{tabular}{|l|l|} 
Brine Effectiveness \\
\end{tabular} & W-h/lb & 10.86 & & & & & \\
\hline & Plant Cost & $\$ / k W$ & 2,140 & & & & & \\
\hline & Production Well Cost & \$K/well & 4,918 & & & & & \\
\hline & Injector Well Cost & \$K/well & 4,918 & & & & & \\
\hline & Surface Equipment Cost & \$K/well & 100 & & & & & \\
\hline & Exploration Success & Ratio & 0.80 & & & & & \\
\hline & \begin{tabular}{|l|} 
Confirmation Success \\
\end{tabular} & Ratio & 0.80 & & & & & \\
\hline & Stimulation Cost & \$K/well & 750 & & & & & \\
\hline & Production Well Flow Rate & gpm/well & 332 & & & & & \\
\hline & Temperature Drawdown Rate & \%/year & $3.00 \%$ & $10.0 \%$ & $20.0 \%$ & $40.0 \%$ & $60 \%$ & $\begin{array}{l}\text { Experts assumed double improvement ranges from EGS Binary } 2010 \text { Case, and Probability of Success would } \\
\text { be atleast } 60 \%\end{array}$ \\
\hline & Annual O\&M non-labor & $\%$ & $1.5 \%$ & & & & & \\
\hline & Number of O\&M staff & $\#$ & 14.6 & & & & & \\
\hline \multirow{13}{*}{$\begin{array}{l}\text { TIO 7-Improve } \\
\text { artificial lift } \\
\text { technology }\end{array}$} & Utilization Factor & $\%$ & $95 \%$ & & & & & \\
\hline & \begin{tabular}{|l|l} 
Brine Effectiveness \\
\end{tabular} & W-h/lb & 10.86 & & & & & \\
\hline & Plant Cost & $\$ / k W$ & 2,140 & & & & & \\
\hline & Production Well Cost & Sk/well & 4,918 & & & & & \\
\hline & Injector Well Cost & SK/well & 4,918 & & & & & \\
\hline & Surface Equipment Cost & \$K/well & 100 & & & & & \\
\hline & Exploration Success & Ratio & 0.80 & & & & & \\
\hline & \begin{tabular}{|l|} 
Confirmation Success \\
\end{tabular} & Ratio & 0.80 & & & & & \\
\hline & Stimulation cost & \$K/well & 750 & & & & & \\
\hline & Production Well Flow Rate & gpm/well & 332 & $2.0 \%$ & $100.0 \%$ & $400.0 \%$ & $60 \%$ & $\begin{array}{l}\text { Experts assumed double improvement ranges from EGS Binary } 2010 \text { Case, and Probability of Success would } \\
\text { be atleast } 60 \%\end{array}$ \\
\hline & Temperature Drawdown Rate & \%/year & $3.00 \%$ & & & & & \\
\hline & \begin{tabular}{|l|l|} 
Annual O\&M non-labor \\
\end{tabular} & $\%$ & $1.5 \%$ & & & & & \\
\hline & Number of O\&M staff & $\#$ & 14.6 & & & & & \\
\hline \multirow{13}{*}{$\begin{array}{l}\text { TIO 8- Improve short } \\
\text { circuit mitigation } \\
\text { methods }\end{array}$} & Utilization Factor & $\%$ & $95 \%$ & & & & & \\
\hline & \begin{tabular}{|l|} 
Brine Effectiveness \\
\end{tabular} & W-h/lb & 10.86 & & & & & \\
\hline & Plant Cost & $\$ / k W$ & 2,140 & & & & & \\
\hline & Production Well Cost & \$K/well & 4,918 & & & & & \\
\hline & Injector Well Cost & SK/well & 4,918 & & & & & \\
\hline & Surface Equipment Cost & SK/well & 100 & & & & & \\
\hline & Exploration Success & Ratio & 0.80 & & & & & \\
\hline & Confirmation Success & Ratio & 0.80 & & & & & \\
\hline & Stimulation Cost & \$K/well & 750 & $2.0 \%$ & $50.0 \%$ & $75.0 \%$ & $60 \%$ & $\begin{array}{l}\text { Experts assumed double improvement ranges from EGS Binary } 2010 \text { Case, and Probability of Success would } \\
\text { be atleast } 60 \%\end{array}$ \\
\hline & Production Well Flow Rate & gpm/well & 332 & $2.0 \%$ & $100.0 \%$ & $200.0 \%$ & $60 \%$ & $\begin{array}{l}\text { Experts assumed double improvement ranges from EGS Binary } 2010 \text { Case, and Probability of Success would } \\
\text { be atleast } 60 \%\end{array}$ \\
\hline & Temperature Drawdown Rate & \%/year & $3.00 \%$ & & & & & \\
\hline & Annual O\&M non-labor & $\%$ & $1.5 \%$ & & & & & \\
\hline & Number of O\&M staff & \# & 14.6 & & & & & \\
\hline
\end{tabular}




\begin{tabular}{|c|c|c|c|c|c|c|c|c|}
\hline \multirow[b]{3}{*}{ TIO Categories } & \multirow[b]{3}{*}{ GETEM INPUTS/TPMS } & \multicolumn{7}{|c|}{ Evolutionary EGS Binary $20404000 \mathrm{~m}$ at 200C-SYSTEM SCORING SHEET } \\
\hline & & \multirow[b]{2}{*}{ Units } & \multirow{2}{*}{\begin{tabular}{c|c} 
Baseline \\
in 2005
\end{tabular}} & \multicolumn{3}{|c|}{ TIO Improvements in 2040 in \% } & \multirow{2}{*}{$\begin{array}{c}\text { Prob. of } \\
\text { Success \% }\end{array}$} & \multirow[b]{2}{*}{ Comments } \\
\hline & & & & Minimum \% & Expected \% & Maximum \% & & \\
\hline \multirow{13}{*}{$\begin{array}{l}\text { TIO 9- Perform } \\
\text { systems analysis } \\
\text { and integration }\end{array}$} & Utilization Factor & $\%$ & $95 \%$ & & & & & \\
\hline & \begin{tabular}{|l} 
Brine Effectiveness \\
PlantCost
\end{tabular} & W-h/lb & $\frac{10.86}{2140}$ & & & & & \\
\hline & \begin{tabular}{|l|l|l} 
Plant Cost \\
Production Well Cost
\end{tabular} & $\$ / \mathrm{kW}$ & $2,140 \mid$ & & & & & \\
\hline & \begin{tabular}{|l} 
Production Well Cost \\
Injector Well Cost
\end{tabular} & 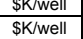 & $\frac{4,918}{4,918}$ & & & & & \\
\hline & \begin{tabular}{|l|l|l|l|l} 
Injector Well Cost \\
Surface Equipment Cost
\end{tabular} & 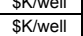 & 4,918 & & & & & \\
\hline & & $\frac{S K \text { Kelll }}{\text { Ratio }}$ & $\frac{100}{0.80}$ & & & & & \\
\hline & \begin{tabular}{|l} 
Exploration Success \\
Confirmation Success \\
\end{tabular} & $\frac{R_{\text {Ratio }}}{\text { Ratio }}$ & 0.80 & & & & & \\
\hline & \begin{tabular}{|l} 
Confirmation Success \\
Stimulation cost
\end{tabular} & & & & & & & Experts assumed double improvement ranges from EGS Binary 2010 Case, and Probability of Success would \\
\hline & Stimulation Cost & \$K/well & 750 & $20.0 \%$ & $30.0 \%$ & $40.0 \%$ & $60 \%$ & be atleast $60 \%$ \\
\hline & Production Well Flow Rate & gpm/well & 332 & $2.0 \%$ & $10.0 \%$ & & $70 \%$ & $\begin{array}{l}\text { Experts assumed double improvement ranges from EGS Binary } 2010 \text { Case, and Probability of Success would } \\
\text { be atleast } 60 \%\end{array}$ \\
\hline & Temperature Drawdown Rate & \%/year & $3.00 \%$ & $2.0 \%$ & $50.0 \%$ & $75.0 \%$ & $60 \%$ & \\
\hline & \begin{tabular}{|l|l|} 
Annual O\&M non-labor \\
\end{tabular} & $\%$ & $1.5 \%$ & & & & & \\
\hline & Number of O\&M staff & $\#$ & 14.6 & & & & & \\
\hline \multirow{13}{*}{$\begin{array}{l}\text { TIO 10- Remote } \\
\text { sensing exploration } \\
\text { methods (InSAR, } \\
\text { hyperspectral } \\
\text { imaging, GPS) }\end{array}$} & Utilization Factor & $\%$ & $95 \%$ & & & & & \\
\hline & \begin{tabular}{|l} 
Brine Effectiveness \\
\end{tabular} & W-h/lb & 10.86 & & & & & \\
\hline & Plant Cost & $\$ / k W$ & 2,140 & & & & & \\
\hline & Production Well Cost & \$K/Well & 4,918 & & & & & \\
\hline & Injector Well Cost & $\$$ \$K/well & 4,918 & & & & & \\
\hline & \begin{tabular}{|l} 
Surface Equipment Cost \\
Exploration Success
\end{tabular} & Ratio & & & & & & Experts assumed double improvement ranges from EGS Binary 2010 Case, and Probability of Success would \\
\hline & Exploration Success & & 0.80 & $2.0 \%$ & $14.0 \%$ & $20.0 \%$ & $60 \%$ & be atleast $60 \%$ \\
\hline & Confirmation Success & Ratio & 0.80 & $2.0 \%$ & $10.0 \%$ & $16.0 \%$ & $60 \%$ & $\begin{array}{l}\text { Experts assumed double improvement ranges from EGS Binary } 2010 \text { Case, and Probability of Success would } \\
\text { be atleast } 60 \%\end{array}$ \\
\hline & Stimulation Cost & \$K/well & 750 & & & & & \\
\hline & \begin{tabular}{|l} 
Production Well Flow Rate \\
\end{tabular} & gpm/well & 332 & & & & & \\
\hline & Temperature Drawdown Rate & \%/year & $3.00 \%$ & & & & & \\
\hline & Annual O\&M non-labor & $\%$ & $1.5 \%$ & & & & & \\
\hline & Number of O\&M staff & \# & 14.6 & & & & & \\
\hline \multirow{13}{*}{$\begin{array}{l}\text { TIO 11- Geophysical } \\
\text { exploration methods } \\
\text { (seismic, } \\
\text { magnetotellurics) }\end{array}$} & \begin{tabular}{|l|l} 
Utilization Factor \\
\end{tabular} & $\%$ & $95 \%$ & & & & & \\
\hline & Brine Effectiveness & W-h/lb & 10.86 & & & & & \\
\hline & Plant Cost & $\$ / k W$ & 2,140 & & & & & \\
\hline & Production Well Cost & \$K/well & 4,918 & & & & & \\
\hline & Injector Well Cost & \$K/well & 4,918 & & & & & \\
\hline & Surface Equipment Cost & \$K/well & 100 & & & & & \\
\hline & Exploration Success & Ratio & 0.80 & $8.0 \%$ & $12.0 \%$ & $16.0 \%$ & $60 \%$ & $\begin{array}{l}\text { Experts assumed double improvement ranges from EGS Binary } 2010 \text { Case, and Probability of Success would } \\
\text { be atleast } 60 \%\end{array}$ \\
\hline & Confirmation Success & Ratio & 0.80 & $14.0 \%$ & $20.0 \%$ & $28.0 \%$ & $60 \%$ & $\begin{array}{l}\text { Experts assumed double improvement ranges from EGS Binary } 2010 \text { Case, and Probability of Success would } \\
\text { be atleast } 60 \%\end{array}$ \\
\hline & Stimulation Cost & \$K/well & 750 & & & & & \\
\hline & Production Well Flow Rate & $\mathrm{gpm} / \mathrm{well}$ & 332 & & & & & \\
\hline & Temperature Drawdown Rate & $\% / y e a r$ & $3.00 \%$ & & & & & \\
\hline & Annual O\&M non-labor & $\%$ & $1.5 \%$ & & & & & \\
\hline & Number of O\&M staff & \# & 14.6 & & & & & \\
\hline \multirow{13}{*}{\begin{tabular}{|} 
TIO 12- Geochemical \\
exploration methods \\
(isotopes, gases)
\end{tabular}} & Utilization Factor & $\%$ & $95 \%$ & & & & & \\
\hline & Brine Effectiveness & W-h/lb & 10.86 & & & & & \\
\hline & \begin{tabular}{|l|} 
Plant Cost \\
\end{tabular} & $\$ / k W$ & 2,140 & & & & & \\
\hline & Production Well Cost & SK/well & 4,918 & & & & & \\
\hline & Injector Well Cost & \$K/Well & 4,918 & & & & & \\
\hline & Surface Equipment Cost & \$K/well & 100 & & & & & \\
\hline & Exploration Success & Ratio & 0.80 & $10.0 \%$ & $30.0 \%$ & $60.0 \%$ & $60 \%$ & $\begin{array}{l}\text { Experts assumed double improvement ranges from EGS Binary } 2010 \text { Case, and Probability of Success would } \\
\text { be atleast } 60 \%\end{array}$ \\
\hline & Confirmation Success & Ratio & 0.80 & $2.0 \%$ & $16.0 \%$ & $30.0 \%$ & $60 \%$ & $\begin{array}{l}\begin{array}{l}\text { Experts assumed double improvement ranges from EGS Binary } 2010 \text { Case, and Probability of Success would } \\
\text { be atleast } 60 \%\end{array} \\
\end{array}$ \\
\hline & Stimulation Cost & \$K/well & 750 & & & & & \\
\hline & Production Well Flow Rate & gpm/well & 332 & & & & & \\
\hline & Temperature Drawdown Rate & \%/year & $3.00 \%$ & & & & & \\
\hline & Annual O\&M non-labor & $\%$ & $\begin{array}{c}1.5 \% \\
146 \\
\end{array}$ & & & & & \\
\hline & Number of O\&M staff & $\#$ & 14.6 & & & & & \\
\hline
\end{tabular}




\begin{tabular}{|c|c|c|c|c|c|c|c|c|}
\hline \multirow[b]{3}{*}{ TIO Categories } & \multirow[b]{3}{*}{ GETEM INPUTS/TPMS } & \multicolumn{7}{|c|}{ Evolutionary EGS Binary $20404000 \mathrm{~m}$ at 200C- SYSTEM SCORING SHEET } \\
\hline & & \multirow[b]{2}{*}{ Units } & \multirow{2}{*}{\begin{tabular}{|c|} 
Baseline \\
in 2005
\end{tabular}} & \multicolumn{3}{|c|}{ TIO Improvements in 2040 in \% } & \multirow{2}{*}{\begin{tabular}{|c|} 
Prob. of \\
Success \%
\end{tabular}} & \multirow{2}{*}{ ( } \\
\hline & & & & Minimum \% & Expected \% & Maximum \% & & \\
\hline \multirow{12}{*}{$\begin{array}{l}\text { TIO 13- National } \\
\text { geothermal } \\
\text { assessment and } \\
\text { supply (EGS, } \\
\text { hydrothermal) }\end{array}$} & \begin{tabular}{|l} 
Utilization Factor \\
\end{tabular} & $\%$ & $95 \%$ & & & & & \\
\hline & Brine Effectiveness & W-h/lb & 10.86 & & & & & \\
\hline & Plant Cost & $\$ / k W$ & 2,140 & & & & & \\
\hline & \begin{tabular}{|l} 
Production Well Cost \\
Injector Well Cost
\end{tabular} & \$K/well & $\frac{4,918}{4,918}$ & & & & & \\
\hline & \begin{tabular}{|l|l|l|l} 
Injector Well Cost \\
Surface Equipment Cost
\end{tabular} & \begin{tabular}{|l|l|l|l|l} 
SK/well \\
\$K/well
\end{tabular} & 4,918 & & & & & \\
\hline & Exploration Success & Ratio & 0.80 & & & & & $\begin{array}{l}\text { Really an enabling TIO that allows the other improvements to be made. Needs to be done to support or } \\
\text { condemn the program. Industry has been pushing for this (thinking that it would be the program going out } \\
\text { and actually drilling wells). }\end{array}$ \\
\hline & Confirmation Success & Ratio & 0.80 & & & & & \\
\hline & \begin{tabular}{|l|l} 
Stimulation Cost \\
\end{tabular} & \$K/well & 750 & & & & & \\
\hline & $\begin{array}{ll}\text { Production Well Flow Rate } \\
\end{array}$ & gpm/well & 332 & & & & & \\
\hline & Temperature Drawdown Rate & $\% / y$ ear & $3.00 \%$ & & & & & \\
\hline & Annual O\&M non-labor & $\%$ & $1.5 \%$ & & & & & \\
\hline & Number of O\&M staff & \# & 14.6 & & & & & \\
\hline \multirow{13}{*}{$\begin{array}{l}\text { TIO 14- Reduction of } \\
\text { drilling time and } \\
\text { expense, especially } \\
\text { in hard abrasive } \\
\text { formations }\end{array}$} & Utilization Factor & $\%$ & $95 \%$ & & & & & \\
\hline & \begin{tabular}{|l} 
Brine Effectiveness \\
Plant Cost
\end{tabular} & \begin{tabular}{|l|l}
$W-h / l b$ \\
$\$ / k W$
\end{tabular} & $\begin{array}{ll}10.86 \\
2,140\end{array}$ & & & & & \\
\hline & Plant cost & & & & & & & Experts assumed for this TIO there would be a greater chance of success and higher range of improvements \\
\hline & Production Well Cost & \$K/well & 4,918 & $5.0 \%$ & $15.0 \%$ & $20.0 \%$ & $80 \%$ & for the 2040 timeframe relative to EGS Binary 2010 case. \\
\hline & Injector Well Cost & \$K/well & 4,918 & $5.0 \%$ & $15.0 \%$ & $20.0 \%$ & $80 \%$ & $\begin{array}{l}\text { Experts assumed for this TIO there would be a greater chance of success and higher range of improvements } \\
\text { for the } 2040 \text { timeframe relative to EGS Binary } 2010 \text { case. }\end{array}$ \\
\hline & Surface Equipment Cost & \$K/well & 100 & & & & & \\
\hline & Exploration Success & Ratio & 0.80 & & & & & \\
\hline & Confirmation Success & Ratio & 0.80 & & & & & \\
\hline & Stimulation Cost & \$K/well & 750 & & & & & \\
\hline & Production Well Flow Rate & gpm/well & 332 & & & & & \\
\hline & Temperature Drawdown Rate & \%/year & $3.00 \%$ & & & & & \\
\hline & Annual O\&M non-labor & $\%$ & $1.5 \%$ & & & & & \\
\hline & Number of O\&M staff & $\#$ & 14.6 & & & & & \\
\hline \multirow{13}{*}{$\begin{array}{l}\text { TIO 15- Reduction } \\
\text { time and expense to } \\
\text { line the wellbore } \\
\text { (including using less } \\
\text { material and less } \\
\text { costly material) }\end{array}$} & \begin{tabular}{|l} 
Utilization Factor \\
\end{tabular} & $\%$ & $95 \%$ & & & & & \\
\hline & \begin{tabular}{|l} 
Brine Effectiveness \\
\end{tabular} & $\begin{array}{ll}\text { W-h/lb } \\
\text { s/lwh }\end{array}$ & $\begin{array}{ll}10.86 \\
2106\end{array}$ & & & & & \\
\hline & Plant Cost & $\$ / k W$ & 2,140 & & & & & \\
\hline & Production Well Cost & \$K/well & 4,918 & $4.0 \%$ & $15.0 \%$ & $20.0 \%$ & $75 \%$ & $\begin{array}{l}\text { Experts assumed for this TIO there would be a greater chance of success and higher range of improvements } \\
\text { for the } 2040 \text { timeframe relative to EGS Binary } 2010 \text { case. }\end{array}$ \\
\hline & Injector Well Cost & SK/well & 4,918 & $4.0 \%$ & $15.0 \%$ & $20.0 \%$ & $75 \%$ & $\begin{array}{l}\text { Experts assumed for this TIO there would be a greater chance of success and higher range of improvements } \\
\text { for the } 2040 \text { timeframe relative to EGS Binary } 2010 \text { case. }\end{array}$ \\
\hline & Surface Equipment Cost & \$K/well & 100 & & & & & \\
\hline & Exploration Success & \begin{tabular}{|l} 
Ratio \\
\end{tabular} & 0.80 & & & & & \\
\hline & \begin{tabular}{|l|} 
Confirmation Success \\
\end{tabular} & Ratio & 0.80 & & & & & \\
\hline & Stimulation Cost & \$K/well & 750 & & & & & \\
\hline & Production Well Flow Rate & gpm/well & 332 & & & & & \\
\hline & Temperature Drawdown Rate & \%/year & $3.00 \%$ & & & & & \\
\hline & Annual O\&M non-labor & $\%$ & $1.5 \%$ & & & & & \\
\hline & Number of O\&M staff & $\#$ & 14.6 & & & & & \\
\hline \multirow{13}{*}{$\begin{array}{l}\text { TIO 16- Reduction of } \\
\text { non-essential flat } \\
\text { time }\end{array}$} & \begin{tabular}{|l|} 
Utilization Factor \\
\end{tabular} & $\%$ & $95 \%$ & & & & & \\
\hline & \begin{tabular}{|l} 
Brine Effectiveness \\
Dlant
\end{tabular} & $\begin{array}{ll}\text { W-h/lb } \\
\Phi(k / W /\end{array}$ & $\begin{array}{ll}10.86 \\
2.140\end{array}$ & & & & & 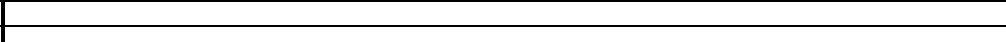 \\
\hline & Plant Cost & $\$ / \mathrm{kWV}$ & 2,140 & & & & & Experts assumed for this TIO there would be the same chance of success and range of improvements for the \\
\hline & Production Well Cost & \$K/well & 4,918 & $2.0 \%$ & $4.0 \%$ & $10.0 \%$ & $50 \%$ & 2040 timeframe relative to EGS Binary 2010 case. \\
\hline & & & & & & & & Experts assumed for this TIO there would be the same chance of success and range of improvements for the \\
\hline & |njector Well Cost & \$K/well & 4,918 & $2.0 \%$ & $4.0 \%$ & 10.0\% & $50 \%$ & 2040 timeframe relative to EGS Binary 2010 case. \\
\hline & \begin{tabular}{|l} 
Surface Equipment Cost \\
Exploration Success
\end{tabular} & $\begin{array}{l}\text { \$K/well } \\
\text { Ratio }\end{array}$ & $\begin{array}{r}100 \\
0.80\end{array}$ & & & & & \\
\hline & \begin{tabular}{|l|l} 
Expioration Success \\
Confirmation Success \\
\end{tabular} & Ratio & 0.00 & & & & & \\
\hline & \begin{tabular}{|l|l} 
Stimulation Cost \\
\end{tabular} & \$K/well & 750 & & & & & \\
\hline & \begin{tabular}{|l} 
Production Well Flow Rate \\
\end{tabular} & gpm/well & 332 & & & & & \\
\hline & Temperature Drawdown Rate & \%/year & $3.00 \%$ & & & & & \\
\hline & Annual O\&M non-labor & $\%$ & $1.5 \%$ & & & & & \\
\hline & Number of O\&M staff & $\#$ & 14.6 & & & & & \\
\hline
\end{tabular}




\begin{tabular}{|c|c|c|c|c|c|c|c|c|}
\hline \multirow[b]{3}{*}{ TIO Categories } & \multirow[b]{3}{*}{ GETEM INPUTS/TPMS } & \multicolumn{7}{|c|}{ Evolutionary EGS Binary $20404000 \mathrm{~m}$ at 200C-SYSTEM SCORING SHEET } \\
\hline & & \multirow[b]{2}{*}{ Units } & \multirow{2}{*}{\begin{tabular}{c|} 
Baseline \\
in 2005 \\
\end{tabular}} & \multicolumn{3}{|c|}{ TIO Improvements in 2040 in \% } & \multirow{2}{*}{$\begin{array}{c}\text { Prob. of } \\
\text { Success \% }\end{array}$} & \multirow[b]{2}{*}{ Comments } \\
\hline & & & & Minimum \% & Expected \% & Maximum \% & & \\
\hline \multirow{13}{*}{$\begin{array}{l}\text { TIO 17- Development } \\
\text { of basic information } \\
\text { through analysis } \\
\text { and simulation } \\
\text { efforts. }\end{array}$} & Utilization Factor & $\%$ & & & & & & \\
\hline & Brine Effectiveness & W-hllb & 10.86 & & & & & \\
\hline & Plant Cost & $\$ / \mathrm{kW}$ & 2,140 & & & & & \\
\hline & Production Well Cost & \$K/Well & 4,918 & $4.0 \%$ & $12.0 \%$ & $15.0 \%$ & $75 \%$ & $\begin{array}{l}\text { Experts assumed tor this IIO there would be the same chance of success, but a higher range of } \\
\text { improvements for the } 2040 \text { timeframe relative to EGS Binary } 2010 \text { case. }\end{array}$ \\
\hline & & & & & & & & Experts assumed for this TIO there would be the same chance of success, but a higher range of \\
\hline & & \$K/well & 4,918 & $4.0 \%$ & $12.0 \%$ & $15.0 \%$ & $75 \%$ & improvements for the 2040 timeframe relative to EGS Binary 2010 case. \\
\hline & \begin{tabular}{|l} 
Surface Equipment Cost \\
Exploration Success
\end{tabular} & \$K/well & 100 & & & & & \\
\hline & Confirmation Success & 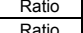 & 0.80 & & & & & \\
\hline & Stimulation Cost & $\begin{array}{ll}\text { Ratio } \\
\text { SK/well }\end{array}$ & $\frac{0.80}{750}$ & & & & & \\
\hline & \begin{tabular}{|l} 
Production Well Flow Rate \\
\end{tabular} & $\mathrm{gpm} / \mathrm{well}$ & 332 & & & & & \\
\hline & Temperature Drawdown Rate & \%/year & $3.00 \%$ & & & & & \\
\hline & Annual O\&M non-labor & $\%$ & $1.5 \%$ & & & & & \\
\hline & Number of O\&M staff & \# & 14.6 & & & & & \\
\hline \multirow{13}{*}{$\begin{array}{l}\text { TIO 18-Completion } \\
\text { and production } \\
\text { related development } \\
\text { projects }\end{array}$} & \begin{tabular}{|l|l} 
Utilization Factor \\
Prine
\end{tabular} & $\%$ & $95 \%$ & & & & & \\
\hline & \begin{tabular}{|l} 
Brine Effectiveness \\
Plant Cost
\end{tabular} & $\begin{array}{ll}W-h / l b \\
\$ / k W\end{array}$ & $\begin{array}{ll}10.86 \\
2,140\end{array}$ & & & & & \\
\hline & Production Well Cost & \$K/well & 4,918 & $2.5 \%$ & $4.0 \%$ & $7.0 \%$ & $70 \%$ & $\begin{array}{l}\text { Experts assumed for this TIO there would be a greater chance of success, but the same range of } \\
\text { improvements for the } 2040 \text { timeframe relative to EGS Binary } 2010 \text { case. }\end{array}$ \\
\hline & & & & & & & & Experts assumed for this TIO there would be a greater chance of success, but the same range of \\
\hline & \begin{tabular}{|l|l} 
Injector Well Cost \\
SSuffece Eavipment Cost
\end{tabular} & \$K/well & 4,918 & $2.5 \%$ & $4.0 \%$ & $7.0 \%$ & $70 \%$ & improvements for the 2040 timeframe relative to EGS Binary 2010 case. \\
\hline & Surface Equipment Cost & \$K/well & 100 & & & & & \\
\hline & Exploration Success & Ratio & 0.80 & & & & & \\
\hline & \begin{tabular}{|l} 
Confirmation Success \\
Stimultion
\end{tabular} & Ratio & 0.80 & & & & & \\
\hline & Stimulation Cost & \$K/Well & 750 & & & & & \\
\hline & \begin{tabular}{|l|l|l} 
Production Well Flow Rate \\
Temperature Drawdown Rate
\end{tabular} & gpm/well & 332 & & & & & \\
\hline & \begin{tabular}{|l} 
Temperature Drawdown Rate \\
Annual O\&M non-labor
\end{tabular} & \%/year & $3.00 \%$ & & & & & \\
\hline & Annual O\&M non-labor & $\%$ & $1.5 \%$ & & & & & \\
\hline & Number of O\&M staff & \# & 14.6 & & & & & \\
\hline \multirow{13}{*}{$\begin{array}{l}\text { TIO 19-Cycle } \\
\text { Related }\end{array}$} & Utilization Factor & $\%$ & $95 \%$ & $1.0 \%$ & $3.0 \%$ & $4.0 \%$ & $90 \%$ & $\begin{array}{l}\text { Experts assumed the same improvements and probabilities as the EGS Binary } 2010 \text { case, unless otherwise } \\
\text { noted. }\end{array}$ \\
\hline & Brine Effectiveness & W-h/lb & 10.86 & $10.0 \%$ & $25.0 \%$ & $40.0 \%$ & $90 \%$ & Can always add thermal efficiency at increased cost - but usually not economic \\
\hline & Plant Cost & $\$ / k W$ & & $-10 \%$ & $10.0 \%$ & $30.0 \%$ & $30 \%$ & Experts suggested the need to focus on lower cost and better economics rather than efficiency gains. Also, \\
\hline & Production Well Cost & SK/well & 2,4918 & & & & & \\
\hline & Injector Well Cost & SK/well & 4,918 & & & & & \\
\hline & Surface Equipment Cost & \$K/well & 100 & & & & & \\
\hline & Exploration Success & Ratio & 0.80 & & & & & \\
\hline & Confirmation Success & Ratio & 0.80 & & & & & \\
\hline & Stimulation Cost & \$K/well & 750 & & & & & \\
\hline & Production Well Flow Rate & $\mathrm{gpm} / \mathrm{well}$ & 332 & & & & & \\
\hline & Temperature Drawdown Rate & $\% /$ year & $3.00 \%$ & & & & & \\
\hline & \begin{tabular}{|l|} 
Annual O\&M non-labor \\
\end{tabular} & $\%$ & $1.5 \%$ & & & & & \\
\hline & Number of O\&M staff & $\#$ & 14.6 & & & & & \\
\hline \multirow{13}{*}{$\begin{array}{l}\text { TIO 20- Component } \\
\text { Related }\end{array}$} & Utilization Factor & $\%$ & $95 \%$ & $1.0 \%$ & $3.0 \%$ & $4.0 \%$ & $80 \%$ & \\
\hline & Brine Effectiveness & W-h/lb & 10.86 & $3.3 \%$ & $8.0 \%$ & $12.5 \%$ & $75 \%$ & \\
\hline & Plant Cost & $\$ / k W$ & 2,140 & $2.0 \%$ & $5.0 \%$ & $7.8 \%$ & $75 \%$ & \\
\hline & Production Well Cost & \$K/Well & 4,918 & & & & & \\
\hline & Injector Well Cost & SK/well & 4,918 & & & & & \\
\hline & Surface Equipment Cost & \$K/well & 100 & & & & & \\
\hline & Exploration Success & Ratio & 0.80 & & & & & \\
\hline & Confirmation Success & Ratio & 0.80 & & & & & \\
\hline & Stimulation Cost & \$K/well & 750 & & & & & \\
\hline & Production Well Flow Rate & $\mathrm{gpm} / \mathrm{well}$ & 332 & & & & & \\
\hline & Temperature Drawdown Rate & \%/year & $3.00 \%$ & & & & & \\
\hline & \begin{tabular}{|l|} 
Annual O\&M non-labor \\
\end{tabular} & $\%$ & $1.5 \%$ & $0.0 \%$ & $5.0 \%$ & $8.0 \%$ & $50 \%$ & \\
\hline & Number of O\&M staff & $\#$ & 14.6 & & & & & \\
\hline
\end{tabular}




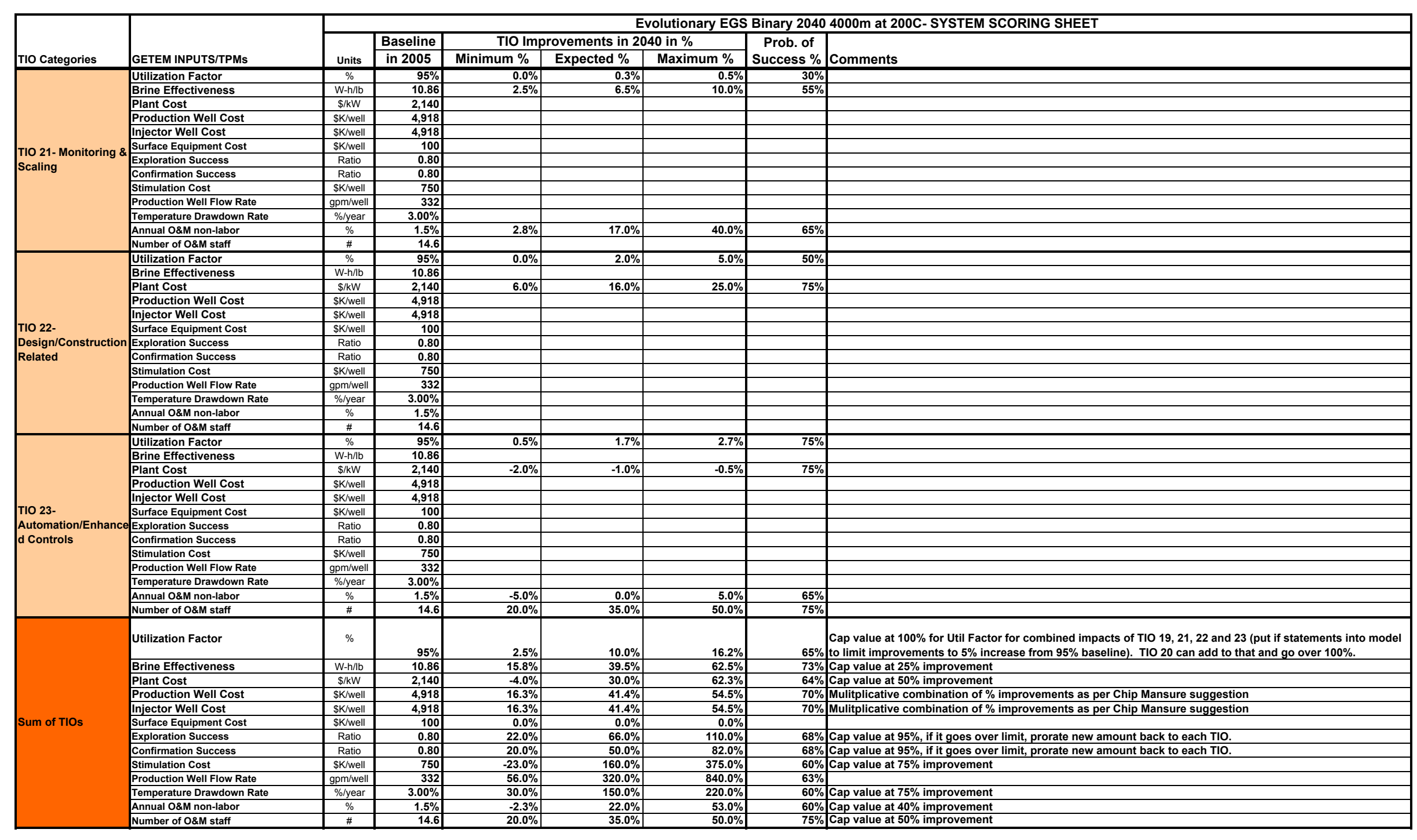




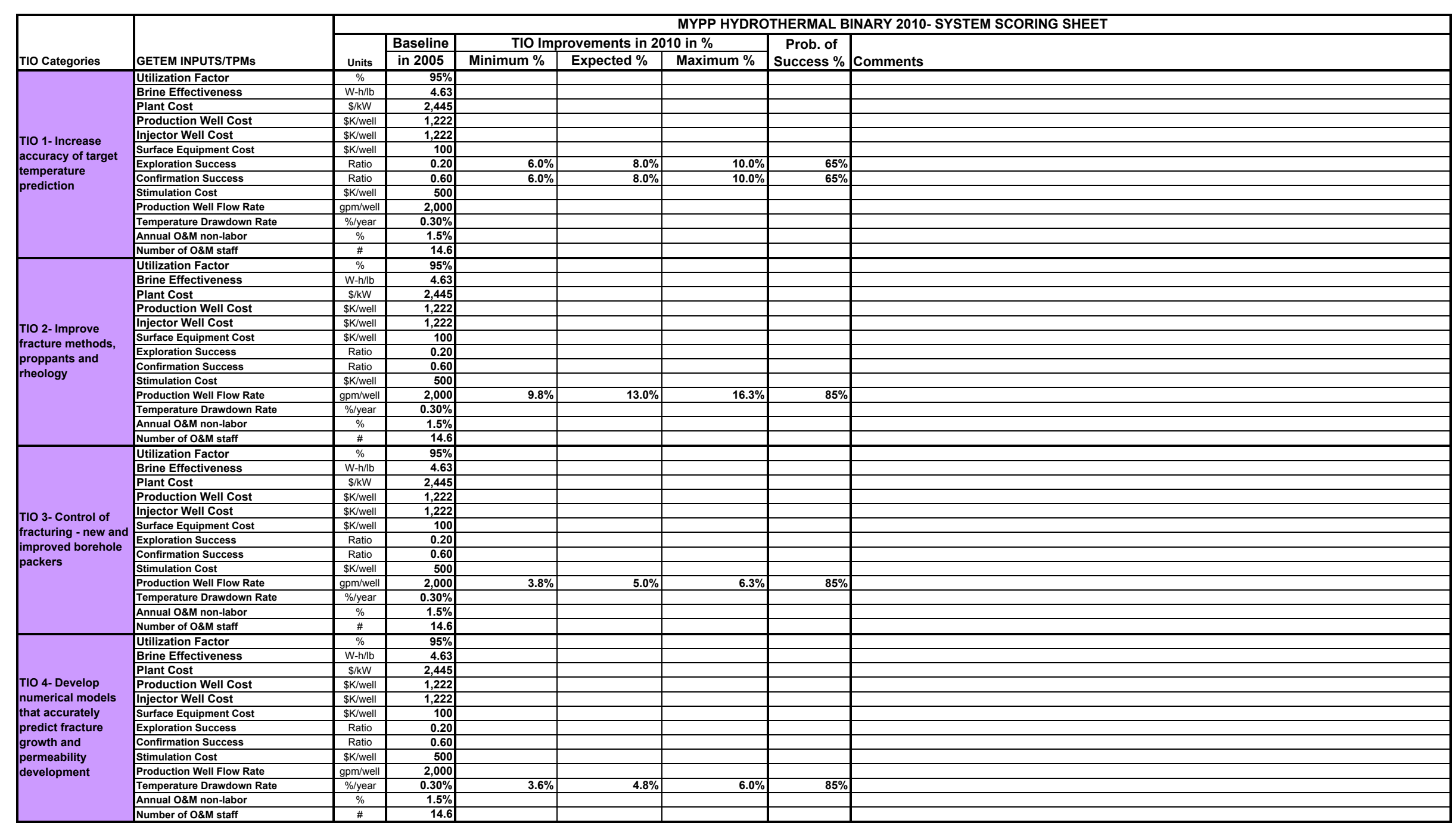




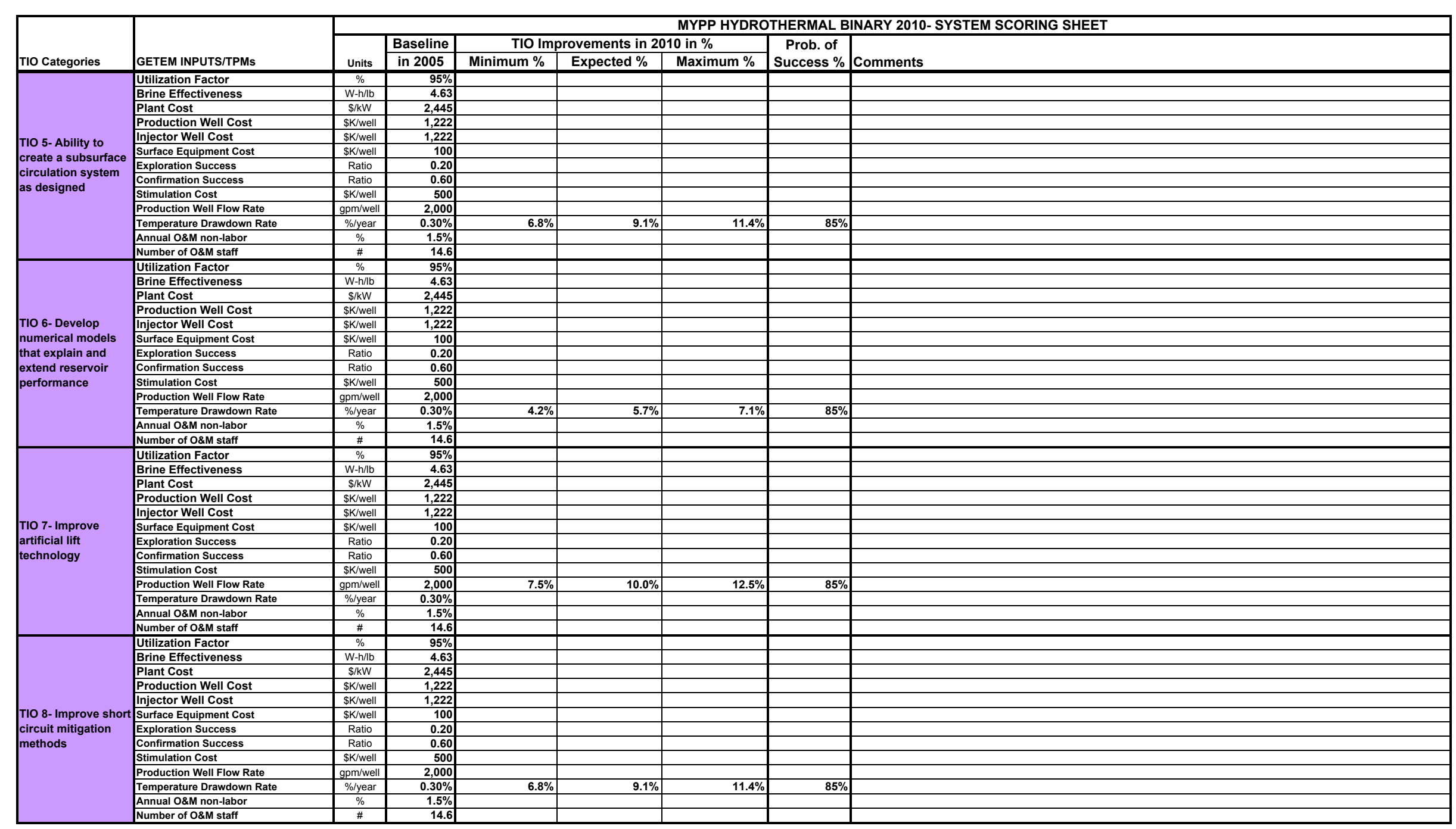




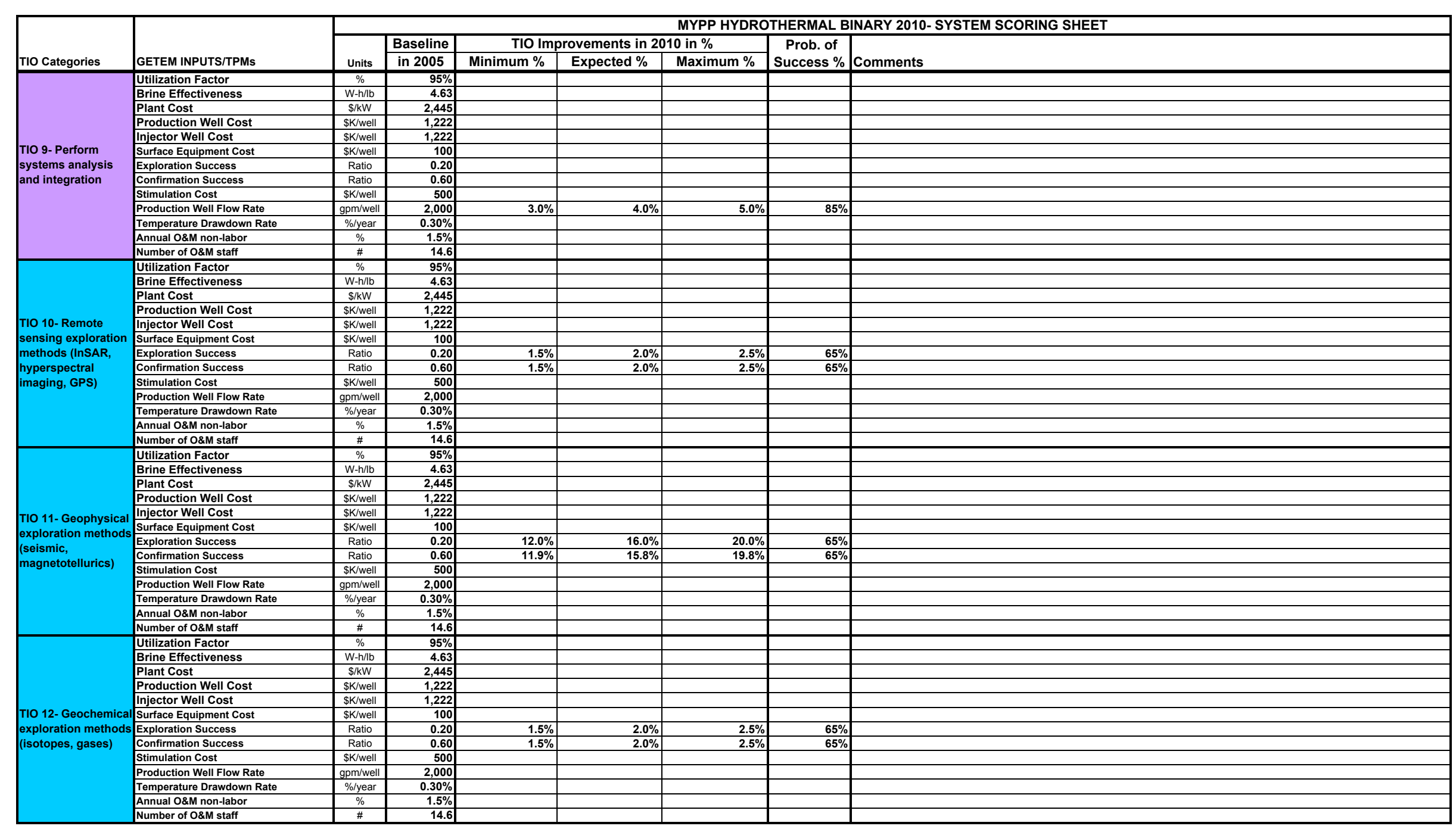




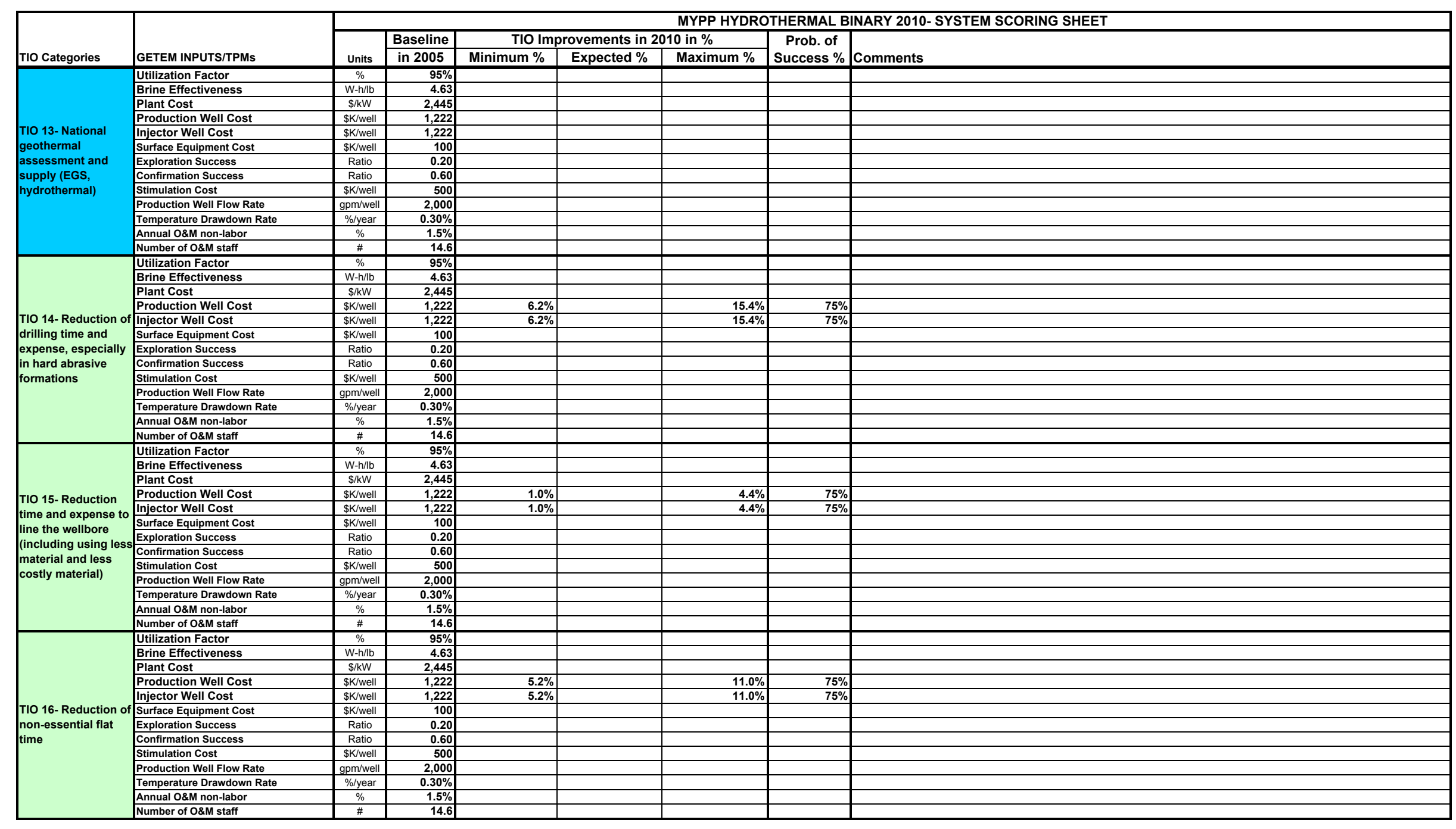




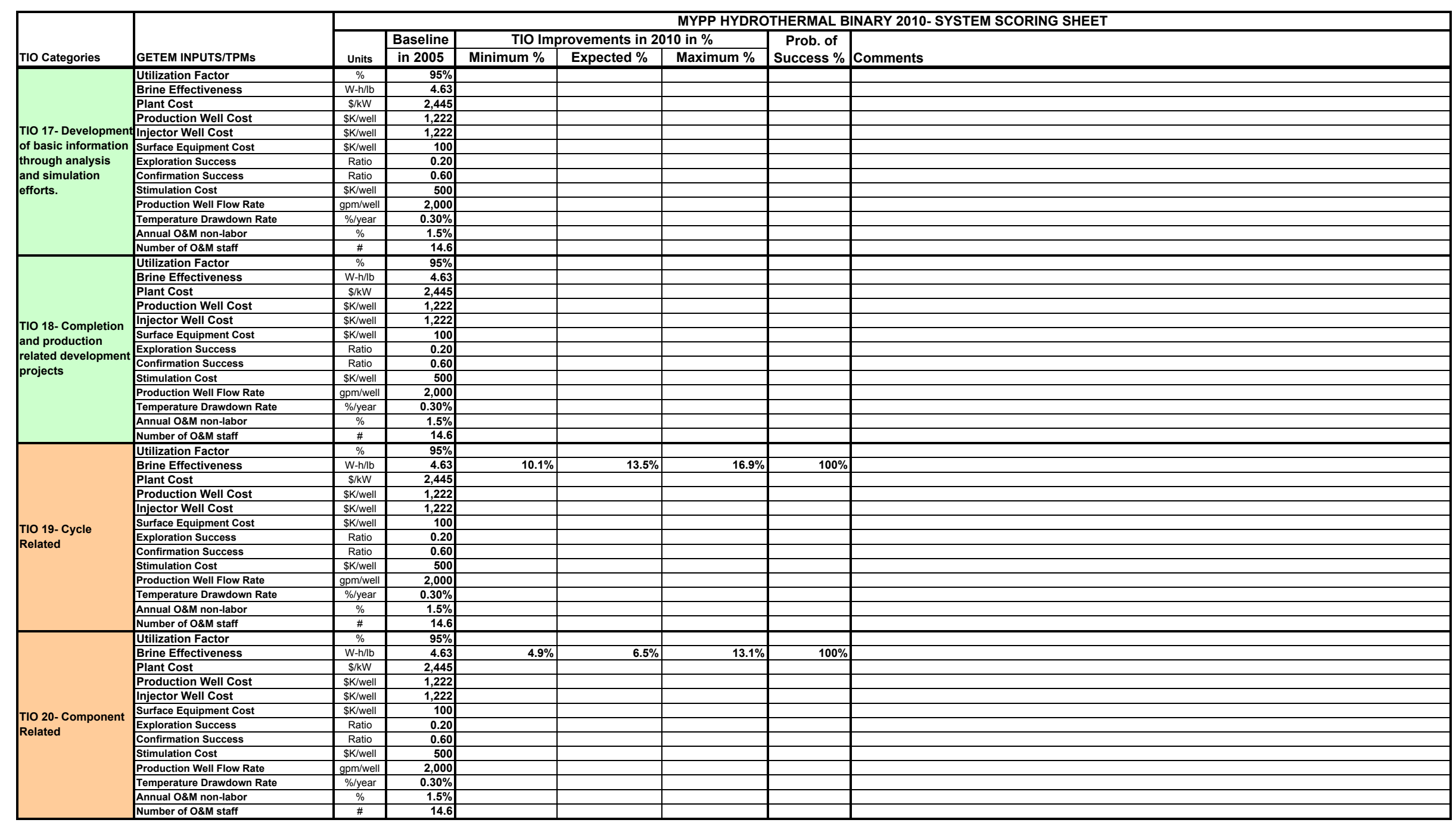




\begin{tabular}{|c|c|c|c|c|c|c|c|c|}
\hline \multirow[b]{3}{*}{ TIO Categories } & \multirow[b]{3}{*}{ GETEM INPUTS/TPMS } & \multicolumn{7}{|c|}{ MYPP HYDROTHERMAL BINARY 2010- SYSTEM SCORING SHEET } \\
\hline & & \multirow[b]{2}{*}{ Units } & \multirow{2}{*}{\begin{tabular}{|l} 
Baseline \\
in 2005 \\
\end{tabular}} & \multicolumn{3}{|c|}{ TIO Improvements in 2010 in \% } & \multirow{2}{*}{\begin{tabular}{|c|} 
Prob. of \\
Success \%
\end{tabular}} & \multirow[b]{2}{*}{ Comments } \\
\hline & & & & Minimum \% & Expected \% & Maximum \% & & \\
\hline \multirow{12}{*}{$\begin{array}{l}\text { TIO 21- Monitoring \& } \\
\text { Scaling }\end{array}$} & \begin{tabular}{|l} 
Utilization Factor \\
\end{tabular} & $\%$ & $95 \%$ & & & & & \\
\hline & \begin{tabular}{|l|} 
Brine Effectiveness \\
Plant Cost
\end{tabular} & 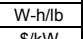 & 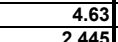 & & & & & \\
\hline & \begin{tabular}{|l|} 
Plant Cost \\
Production Well Cost
\end{tabular} & $\$$ SkW & \begin{tabular}{l|l}
2,445 \\
1,222
\end{tabular} & & & & & \\
\hline & Injector Well Cost & SK/well & 1,222 & & & & & \\
\hline & Surface Equipment Cost & \$K/well & 100 & & & & & \\
\hline & Exploration Success & Ratio & 0.20 & & & & & \\
\hline & Confirmation Success & Ratio & 0.60 & & & & & \\
\hline & Stimulation Cost & \$K/well & 500 & & & & & \\
\hline & Production Well Flow Rate & $\mathrm{gpm} / \mathrm{well}$ & 2,000 & & & & & \\
\hline & Temperature Drawdown Rate & \%/year & $0.30 \%$ & & & & & \\
\hline & Annual O\&M non-labor & $\%$ & $1.5 \%$ & $46.4 \%$ & $58.0 \%$ & $72.5 \%$ & $100 \%$ & \\
\hline & Number of O\&M staff & \# & 14.6 & & & & & \\
\hline \multirow{13}{*}{$\begin{array}{l}\text { TIO 22- } \\
\text { Design/Construction } \\
\text { Related }\end{array}$} & Utilization Factor & $\%$ & $95 \%$ & & & & & \\
\hline & \begin{tabular}{|l|l} 
Brine Effectiveness \\
\end{tabular} & W-h/lb & 4.63 & & & & & \\
\hline & Plant Cost & 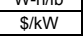 & 2,445 & $15.0 \%$ & $18.0 \%$ & $22.6 \%$ & $100 \%$ & \\
\hline & Production Well Cost & \$K/well & 1,222 & & & & & \\
\hline & Injector Well Cost & \$K/well & 1,222 & & & & & \\
\hline & Surface Equipment Cost & \$K/well & 100 & & & & & \\
\hline & Exploration Success & Ratio & 0.20 & & & & & \\
\hline & Confirmation Success & Ratio & 0.60 & & & & & \\
\hline & Stimulation Cost & \$K/well & 500 & & & & & \\
\hline & Production Well Flow Rate & gpm/well & 2,000 & & & & & \\
\hline & Temperature Drawdown Rate & \%/year & $0.30 \%$ & & & & & \\
\hline & Annual O\&M non-labor & $\%$ & $1.5 \%$ & & & & & \\
\hline & Number of O\&M staff & \# & 14.6 & & & & & \\
\hline \multirow{13}{*}{$\begin{array}{l}\text { TiO 23- } \\
\text { Automation/Enhance } \\
\text { d Controls }\end{array}$} & Utilization Factor & $\%$ & $95 \%$ & & & & & \\
\hline & \begin{tabular}{|l|} 
Brine Effectiveness \\
\end{tabular} & W-h/lb & 4.63 & & & & & \\
\hline & Plant Cost & $\$ s / k W$ & 2,445 & & & & & \\
\hline & Production Well Cost & \$K/Well & 1,222 & & & & & \\
\hline & Injector Well Cost & \$K/well & 1,222 & & & & & \\
\hline & Surface Equipment Cost & \$K/well & 100 & & & & & \\
\hline & Exploration Success & Ratio & 0.20 & & & & & \\
\hline & Confirmation Success & Ratio & 0.60 & & & & & \\
\hline & Stimulation Cost & \$K/well & 500 & & & & & \\
\hline & Production Well Flow Rate & gpm/well & 2,000 & & & & & \\
\hline & Temperature Drawdown Rate & \%/year & $0.30 \%$ & & & & & \\
\hline & \begin{tabular}{|l|} 
Annual O\&M non-labor \\
\end{tabular} & $\%$ & $1.5 \%$ & & & & & \\
\hline & Number of O\&M staff & $\#$ & 14.6 & $40.0 \%$ & $50.0 \%$ & $62.5 \%$ & $100 \%$ & \\
\hline \multirow{13}{*}{ Sum of TIOs } & Utilization Factor & $\%$ & $95 \%$ & $0.0 \%$ & $0.0 \%$ & $0.0 \%$ & & $\begin{array}{l}\text { Cap value at } 100 \% \text { for Util Factor for combined impacts of TIO } 19,21,22 \text { and } 23 \text { (put if statements into model } \\
\text { to limit improvements to } 5 \% \text { increase from } 95 \% \text { baseline). TIO } 20 \text { can add to that and go over } 100 \% \text {. }\end{array}$ \\
\hline & Brine Effectiveness & W-h/lb & 4.63 & $15.0 \%$ & $20.0 \%$ & $30.0 \%$ & $100 \%$ & Cap value at $25 \%$ improvement \\
\hline & Plant Cost & $\$ / k \mathrm{~W}$ & 2,445 & $15.0 \%$ & $18.0 \%$ & $22.6 \%$ & $100 \%$ & Cap value at $50 \%$ improvement \\
\hline & Production Well Cost & \$K/well & 1,222 & $12.0 \%$ & $0.0 \%$ & $28.0 \%$ & $75 \%$ & Mulitplicative combination of $\%$ improvements as per Chip Mansure suggestion \\
\hline & Injector Well Cost & SK/well & 1,222 & $12.0 \%$ & $0.0 \%$ & $28.0 \%$ & $75 \%$ & Mulitplicative combination of \% improvements as per Chip Mansure suggestion \\
\hline & Surface Equipment Cost & \$K/well & 100 & $0.0 \%$ & $0.0 \%$ & $0.0 \%$ & & \\
\hline & Exploration Success & Ratio & 0.20 & $21.0 \%$ & $28.0 \%$ & $35.0 \%$ & $65 \%$ & Cap value at $95 \%$, if it goes over limit, prorate new amount back to each TIO. \\
\hline & Confirmation Success & Ratio & 0.60 & $20.9 \%$ & $27.8 \%$ & $34.8 \%$ & $65 \%$ & Cap value at $95 \%$, if it goes over limit, prorate new amount back to each TIO. \\
\hline & Stimulation Cost & \$K/well & 500 & $0.0 \%$ & $0.0 \%$ & $0.0 \%$ & & Cap value at $75 \%$ improvement \\
\hline & Production Well Flow Rate & gpm/well & 2,000 & $24.0 \%$ & $32.0 \%$ & $40.0 \%$ & $85 \%$ & \\
\hline & Temperature Drawdown Rate & $\% / y e a r$ & $0.30 \%$ & $21.5 \%$ & $28.6 \%$ & $35.8 \%$ & $85 \%$ & Cap value at $75 \%$ improvement \\
\hline & Annual O\&M non-labor & $\%$ & $1.5 \%$ & $46.4 \%$ & $58.0 \%$ & $72.5 \%$ & $100 \%$ & Cap value at $40 \%$ improvement \\
\hline & Number of O\&M staff & \# & 14.6 & $40.0 \%$ & $50.0 \%$ & $62.5 \%$ & $100 \%$ & Cap value at $50 \%$ improvement \\
\hline
\end{tabular}




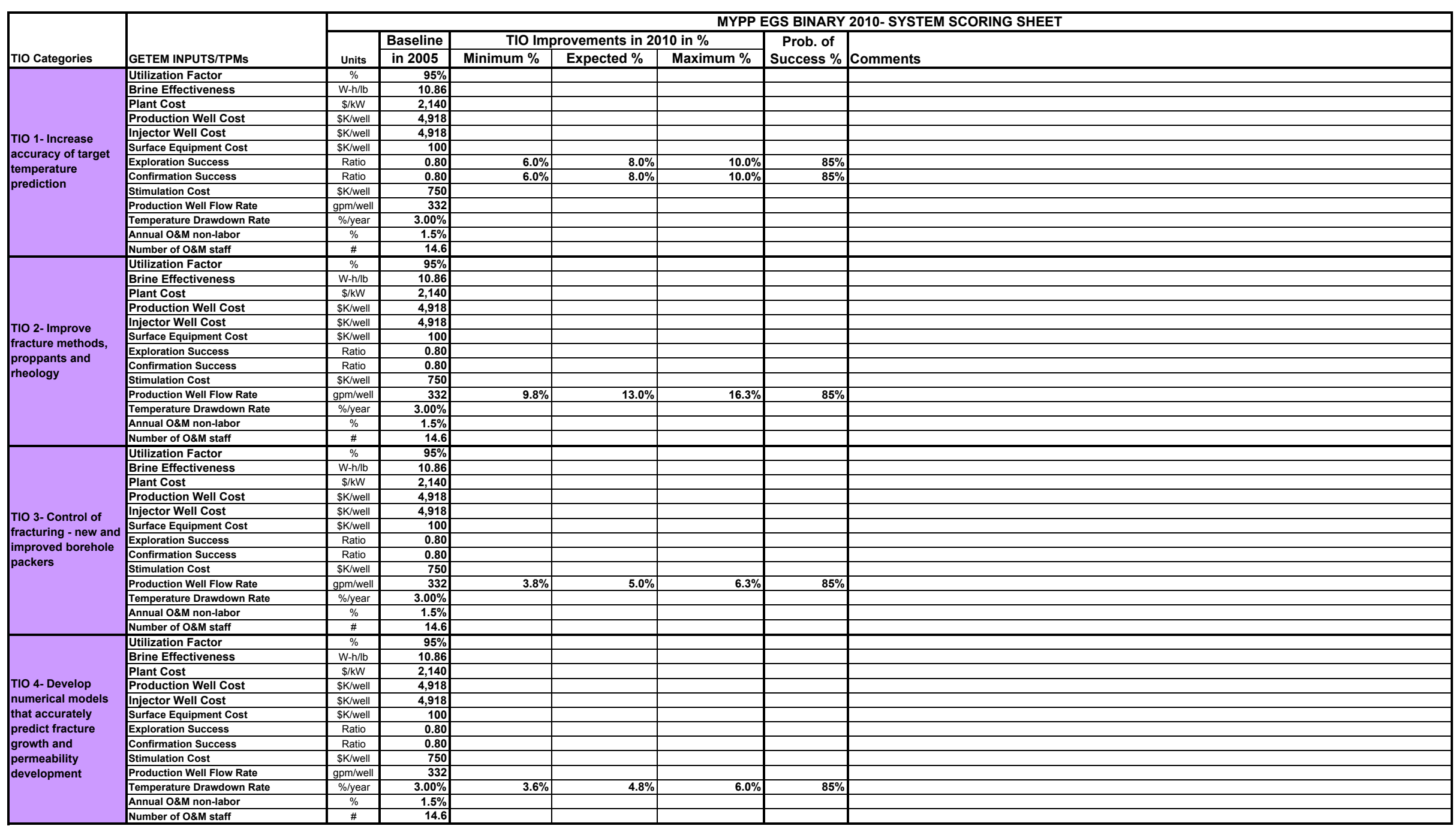




\begin{tabular}{|c|c|c|c|c|c|c|c|c|}
\hline \multirow[b]{3}{*}{ TIO Categories } & \multirow[b]{3}{*}{ GETEM INPUTS/TPMs } & \multicolumn{7}{|c|}{ MYPP EGS BINARY 2010-SYSTEM SCORING SHEET } \\
\hline & & \multirow[b]{2}{*}{ Units } & \multirow{2}{*}{$\begin{array}{l}\text { Baseline } \\
\text { in } 2005 \\
\end{array}$} & \multicolumn{3}{|c|}{ TIO Improvements in 2010 in \% } & \multirow{2}{*}{\begin{tabular}{|c|} 
Prob. of \\
Success \%
\end{tabular}} & \multirow[b]{2}{*}{ Comments } \\
\hline & & & & Minimum \% & Expected \% & Maximum \% & & \\
\hline \multirow{12}{*}{$\begin{array}{l}\text { TIO 5-Ability to } \\
\text { create a subsurface } \\
\text { circulation system } \\
\text { as designed }\end{array}$} & Utilization Factor & $\%$ & $95 \%$ & & & & & \\
\hline & & $\frac{W-h / b}{\$ s / k W}$ & 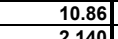 & & & & & \\
\hline & \begin{tabular}{|l} 
Plant Cost \\
Production Well Cost
\end{tabular} & $\begin{array}{ll}\$ \mathrm{~S} / \mathrm{kW} \\
\mathrm{K} / \mathrm{w} \text { ell }\end{array}$ & $\frac{2,140}{4,918}$ & & & & & \\
\hline & Injector Well Cost & SK/well & 4,918 & & & & & \\
\hline & Surface Equipment Cost & SK/well & 100 & & & & & \\
\hline & Exploration Success & Ratio & 0.80 & & & & & \\
\hline & Confirmation Success & Ratio & 0.80 & & & & & \\
\hline & Stimulation Cost & \$K/well & 750 & & & & & \\
\hline & Production Well Flow Rate & gpm/well & 332 & & & & & \\
\hline & Temperature Drawdown Rate & \%/year & $3.00 \%$ & $6.8 \%$ & $9.1 \%$ & $11.4 \%$ & $85 \%$ & \\
\hline & \begin{tabular}{|l|l|} 
Annual O\&M non-labor \\
\end{tabular} & $\%$ & $1.5 \%$ & & & & & \\
\hline & Number of O\&M staff & $\#$ & 14.6 & & & & & \\
\hline \multirow{13}{*}{$\begin{array}{l}\text { TIO 6- Develop } \\
\text { numerical models } \\
\text { that explain and } \\
\text { extend reservoir } \\
\text { performance }\end{array}$} & Utilization Factor & $\%$ & $95 \%$ & & & & & \\
\hline & Brine Effectiveness & W-h/lb & 10.86 & & & & & \\
\hline & Plant Cost & $\$ / k W$ & 2,140 & & & & & \\
\hline & Production Well Cost & SK/well & 4,918 & & & & & \\
\hline & Injector Well Cost & \$K/well & 4,918 & & & & & \\
\hline & Surface Equipment Cost & SK/well & 100 & & & & & \\
\hline & Exploration Success & Ratio & 0.80 & & & & & \\
\hline & \begin{tabular}{|l|} 
Confirmation Success \\
\end{tabular} & Ratio & 0.80 & & & & & \\
\hline & Stimulation Cost & SK/well & 750 & & & & & \\
\hline & Production Well Flow Rate & gpm/well & 332 & & & & & \\
\hline & Temperature Drawdown Rate & \%/year & $3.00 \%$ & $4.2 \%$ & $5.7 \%$ & $7.1 \%$ & $85 \%$ & \\
\hline & Annual O\&M non-labor & $\%$ & $1.5 \%$ & & & & & \\
\hline & Number of O\&M staff & \# & 14.6 & & & & & \\
\hline \multirow{13}{*}{$\begin{array}{l}\text { TIO 7-Improve } \\
\text { artificial lift } \\
\text { technology }\end{array}$} & \begin{tabular}{|l} 
Utilization Factor \\
\end{tabular} & $\%$ & $95 \%$ & & & & & \\
\hline & \begin{tabular}{|l|} 
Brine Effectiveness \\
\end{tabular} & W-h/lb & 10.86 & & & & & \\
\hline & Plant Cost & $\$ / k W$ & 2,140 & & & & & \\
\hline & Production Well Cost & SK/well & 4,918 & & & & & \\
\hline & Injector Well Cost & SK/well & 4,918 & & & & & \\
\hline & Surface Equipment Cost & SK/well & 100 & & & & & \\
\hline & Exploration Success & Ratio & 0.80 & & & & & \\
\hline & Confirmation Success & Ratio & 0.80 & & & & & \\
\hline & Stimulation Cost & \$K/well & 750 & & & & & \\
\hline & Production Well Flow Rate & gpm/well & 332 & $7.5 \%$ & $10.0 \%$ & $12.5 \%$ & $85 \%$ & \\
\hline & Temperature Drawdown Rate & \%/year & $3.00 \%$ & & & & & \\
\hline & Annual O\&M non-labor & $\%$ & $1.5 \%$ & & & & & \\
\hline & Number of O\&M staff & $\#$ & 14.6 & & & & & \\
\hline \multirow{13}{*}{$\begin{array}{l}\text { TIO 8-Improve short } \\
\text { circuit mitigation } \\
\text { methods }\end{array}$} & Utilization Factor & $\%$ & $95 \%$ & & & & & \\
\hline & Brine Effectiveness & W-h/lb & 10.86 & & & & & \\
\hline & Plant Cost & $\$ / k W$ & 2,140 & & & & & \\
\hline & Production Well Cost & SK/well & 4,918 & & & & & \\
\hline & Injector Well Cost & SK/well & 4,918 & & & & & \\
\hline & Surface Equipment Cost & SK/well & 100 & & & & & \\
\hline & Exploration Success & Ratio & 0.80 & & & & & \\
\hline & Confirmation Success & Ratio & 0.80 & & & & & \\
\hline & Stimulation Cost & SK/well & 750 & & & & & \\
\hline & Production Well Flow Rate & gpm/well & 332 & & & & & \\
\hline & Temperature Drawdown Rate & \%/year & $3.00 \%$ & $6.8 \%$ & $9.1 \%$ & $11.4 \%$ & $85 \%$ & \\
\hline & Annual O\&M non-labor & $\%$ & & & & & & \\
\hline & Number of O\&M staff & $\#$ & 14.6 & & & & & \\
\hline
\end{tabular}




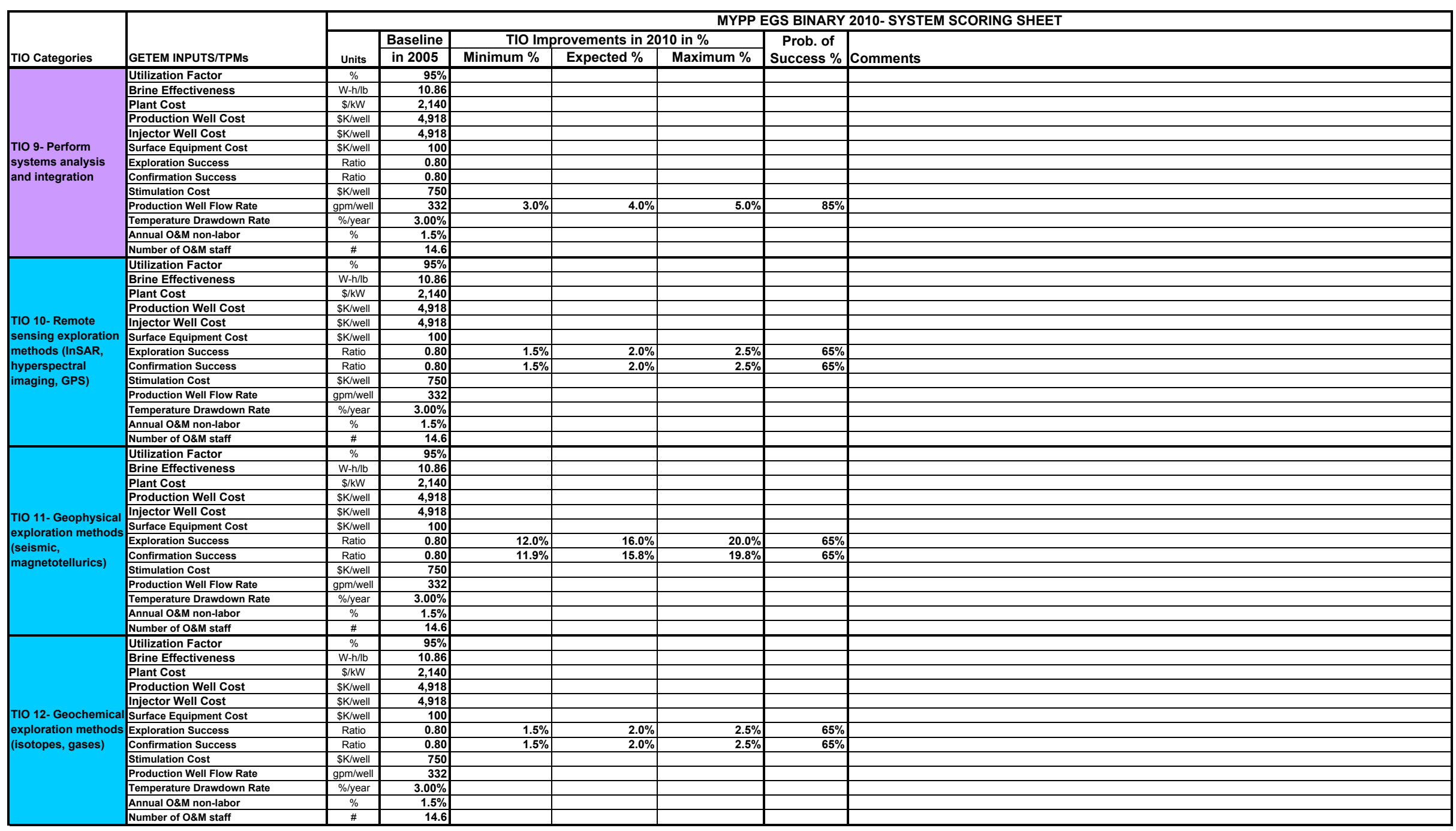




\begin{tabular}{|c|c|c|c|c|c|c|c|c|}
\hline \multirow[b]{3}{*}{ TIO Categories } & \multirow[b]{3}{*}{ GETEM INPUTS/TPMS } & \multicolumn{7}{|c|}{ MYPP EGS BINARY 2010-SYSTEM SCORING SHEET } \\
\hline & & \multirow[b]{2}{*}{ Units } & \multirow{2}{*}{$\begin{array}{l}\text { Baseline } \\
\text { in } 2005 \\
\end{array}$} & \multicolumn{3}{|c|}{ TIO Improvements in 2010 in \% } & \multirow{2}{*}{\begin{tabular}{|c|} 
Prob. of \\
Success \%
\end{tabular}} & \multirow[b]{2}{*}{ Comments } \\
\hline & & & & Minimum \% & Expected \% & Maximum \% & & \\
\hline \multirow{12}{*}{$\begin{array}{l}\text { TIO 13- National } \\
\text { geothermal } \\
\text { assessment and } \\
\text { supply (EGS, } \\
\text { hydrothermal) }\end{array}$} & Utilization Factor & $\%$ & $95 \%$ & & & & & \\
\hline & \begin{tabular}{|l|} 
Brine Effectiveness \\
Plant Cost
\end{tabular} & 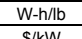 & 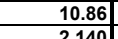 & & & & & \\
\hline & \begin{tabular}{|l} 
Plant Cost \\
Production Well Cost
\end{tabular} & $\begin{array}{lll}\$ \mathrm{~S} / \mathrm{kW} \\
\mathrm{K} / \mathrm{w} \text { ell }\end{array}$ & $\frac{2,140}{4,918}$ & & & & & \\
\hline & Injector Well Cost & SK/well & 4,918 & & & & & \\
\hline & Surface Equipment Cost & SK/well & 100 & & & & & \\
\hline & Exploration Success & Ratio & 0.80 & & & & & \\
\hline & Confirmation Success & Ratio & 0.80 & & & & & \\
\hline & \begin{tabular}{|l|l} 
Stimulation Cost \\
\end{tabular} & SK/well & 750 & & & & & \\
\hline & Production Well Flow Rate & gpm/well & 332 & & & & & \\
\hline & Temperature Drawdown Rate & \%/year & $3.00 \%$ & & & & & \\
\hline & Annual O\&M non-labor & $\%$ & $1.5 \%$ & & & & & \\
\hline & Number of O\&M staff & $\#$ & 14.6 & & & & & \\
\hline \multirow{13}{*}{$\begin{array}{l}\text { TIO 14- Reduction of } \\
\text { drilling time and } \\
\text { expense, especially } \\
\text { in hard abrasive } \\
\text { formations }\end{array}$} & Utilization Factor & $\%$ & $95 \%$ & & & & & \\
\hline & Brine Effectiveness & W-h/lb & 10.86 & & & & & \\
\hline & Plant Cost & $\$ / k W$ & 2,140 & & & & & \\
\hline & Production Well Cost & SK/well & 4,918 & $8.2 \%$ & & $15.4 \%$ & $75 \%$ & \\
\hline & Injector Well Cost & \$K/well & 4,918 & $8.2 \%$ & & $15.4 \%$ & $75 \%$ & \\
\hline & Surface Equipment Cost & SK/well & 100 & & & & & \\
\hline & Exploration Success & Ratio & 0.80 & & & & & \\
\hline & \begin{tabular}{|l} 
Confirmation Success \\
\end{tabular} & Ratio & 0.80 & & & & & \\
\hline & Stimulation Cost & SK/well & 750 & & & & & \\
\hline & Production Well Flow Rate & gpm/well & 332 & & & & & \\
\hline & Temperature Drawdown Rate & \%/year & $3.00 \%$ & & & & & \\
\hline & Annual O\&M non-labor & $\%$ & $1.5 \%$ & & & & & \\
\hline & Number of O\&M staff & \# & 14.6 & & & & & \\
\hline \multirow{13}{*}{\begin{tabular}{|l|} 
TIO 15- Reduction \\
time and expense to \\
line the wellbore \\
(including using less \\
material and less \\
costly material)
\end{tabular}} & \begin{tabular}{|l} 
Utilization Factor \\
\end{tabular} & $\%$ & $95 \%$ & & & & & \\
\hline & \begin{tabular}{|l|} 
Brine Effectiveness \\
\end{tabular} & W-h/lb & 10.86 & & & & & \\
\hline & Plant Cost & $\$ / k W$ & 2,140 & & & & & \\
\hline & Production Well Cost & SK/well & 4,918 & $1.0 \%$ & & $8.8 \%$ & $75 \%$ & \\
\hline & Injector Well Cost & SK/well & 4,918 & $1.0 \%$ & & $8.8 \%$ & $75 \%$ & \\
\hline & Surface Equipment Cost & SK/well & 100 & & & & & \\
\hline & Exploration Success & Ratio & 0.80 & & & & & \\
\hline & Confirmation Success & Ratio & 0.80 & & & & & \\
\hline & Stimulation Cost & \$K/well & 750 & & & & & \\
\hline & Production Well Flow Rate & gpm/well & 332 & & & & & \\
\hline & Temperature Drawdown Rate & \%/year & & & & & & \\
\hline & Annual O\&M non-labor & $\%$ & $1.5 \%$ & & & & & \\
\hline & Number of O\&M staff & $\#$ & 14.6 & & & & & \\
\hline \multirow{13}{*}{$\begin{array}{l}\text { TIO 16- Reduction of } \\
\text { non-essential flat } \\
\text { time }\end{array}$} & \begin{tabular}{|l} 
Utilization Factor \\
\end{tabular} & $\%$ & $95 \%$ & & & & & \\
\hline & Brine Effectiveness & W-h/lb & 10.86 & & & & & \\
\hline & Plant Cost & $\$ / k W$ & 2,140 & & & & & \\
\hline & Production Well Cost & SK/well & 4,918 & $3.1 \%$ & & $6.6 \%$ & $75 \%$ & \\
\hline & Injector Well Cost & SK/well & 4,918 & $3.1 \%$ & & $6.6 \%$ & $75 \%$ & \\
\hline & Surface Equipment Cost & SK/well & 100 & & & & & \\
\hline & Exploration Success & Ratio & 0.80 & & & & & \\
\hline & Confirmation Success & Ratio & 0.80 & & & & & \\
\hline & Stimulation Cost & SK/well & 750 & & & & & \\
\hline & Production Well Flow Rate & gpm/well & 332 & & & & & \\
\hline & Temperature Drawdown Rate & \%/year & $3.00 \%$ & & & & & \\
\hline & Annual O\&M non-labor & $\%$ & & & & & & \\
\hline & Number of O\&M staff & $\#$ & 14.6 & & & & & \\
\hline
\end{tabular}




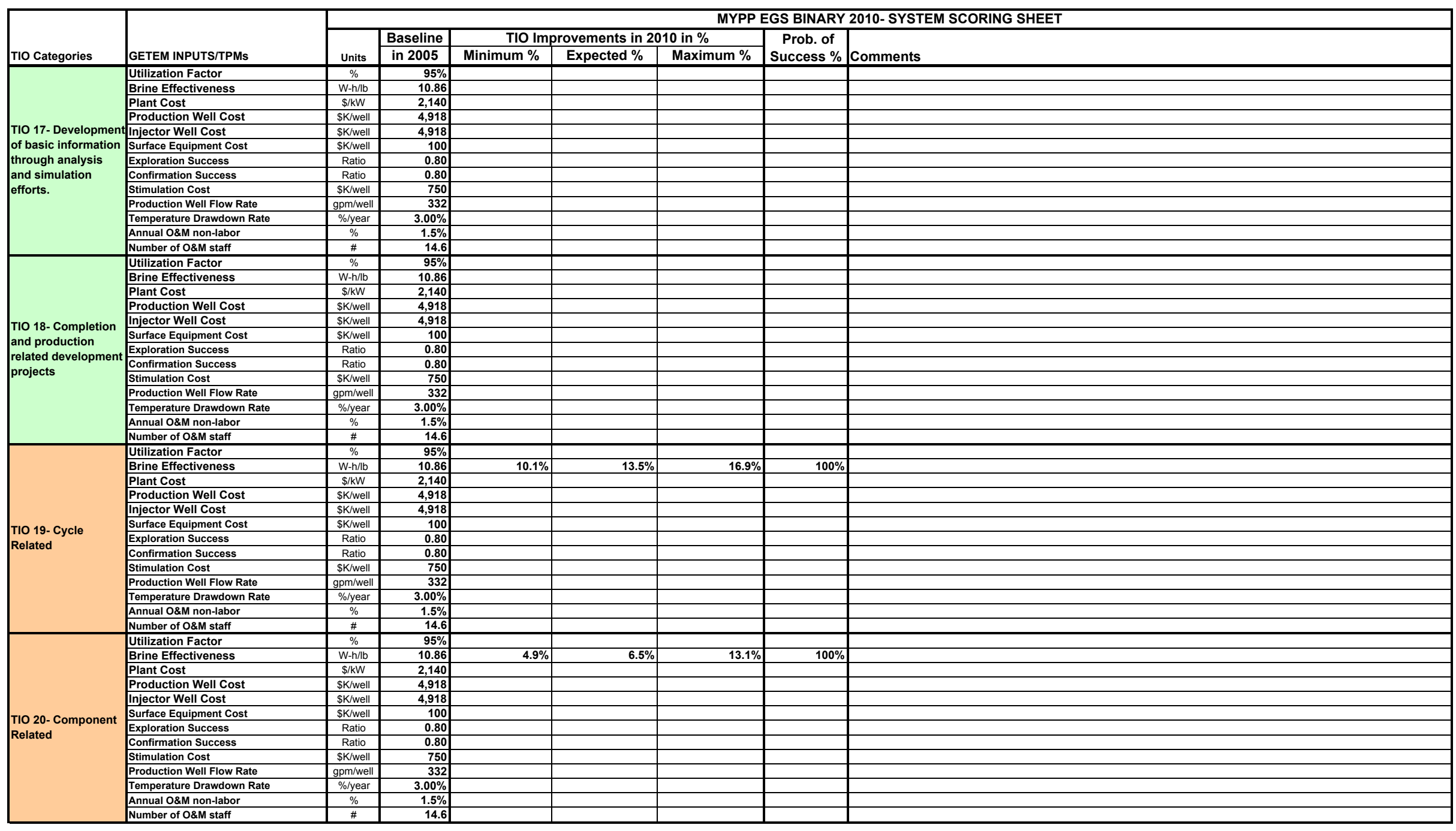




\begin{tabular}{|c|c|c|c|c|c|c|c|c|}
\hline \multirow[b]{3}{*}{ TIO Categories } & \multirow[b]{3}{*}{ GETEM INPUTS/TPMS } & \multicolumn{7}{|c|}{ MYPP EGS BINARY 2010- SYSTEM SCORING SHEET } \\
\hline & & \multirow[b]{2}{*}{ Units } & \multirow{2}{*}{\begin{tabular}{|c|} 
Baseline \\
in 2005 \\
\end{tabular}} & \multicolumn{3}{|c|}{ TIO Improvements in 2010 in \% } & \multirow{2}{*}{$\begin{array}{c}\text { Prob. of } \\
\text { Success \% }\end{array}$} & \multirow[b]{2}{*}{ Comments } \\
\hline & & & & Minimum \% & Expected \% & Maximum \% & & \\
\hline \multirow{13}{*}{$\begin{array}{l}\text { TIO 21- Monitoring } 8 \\
\text { Scaling }\end{array}$} & Utilization Factor & $\%$ & $95 \%$ & & & & & \\
\hline & Brine Effectiveness & W-h/lb & 10.86 & & & & & \\
\hline & Plant Cost & $\$ / \mathrm{kW}$ & 2,140 & & & & & \\
\hline & Production Well Cost & SK/well & 4,918 & & & & & \\
\hline & Injector Well Cost & SK/well & 4,918 & & & & & \\
\hline & Surface Equipment Cost & SK/well & 100 & & & & & \\
\hline & Exploration Success & Ratio & 0.80 & & & & & \\
\hline & Confirmation Success & Ratio & 0.80 & & & & & \\
\hline & Stimulation Cost & SK/well & 750 & & & & & \\
\hline & Production Well Flow Rate & $\mathrm{gpm} / \mathrm{well}$ & 332 & & & & & \\
\hline & Temperature Drawdown Rate & \%/year & $3.00 \%$ & & & & & \\
\hline & \begin{tabular}{|l} 
Annual O\&M non-labor \\
\end{tabular} & $\%$ & $0.5 \%$ & $46.4 \%$ & $58.0 \%$ & $72.5 \%$ & $100 \%$ & \\
\hline & Number of O\&M staff & \# & 14.6 & 40.410 & 00.070 & 72.0710 & 10070 & \\
\hline \multirow{13}{*}{$\begin{array}{l}\text { TIO 22- } \\
\text { Design/Construction } \\
\text { Related }\end{array}$} & Utilization Factor & $\%$ & $95 \%$ & & & & & \\
\hline & Brine Effectiveness & W-h/lb & 10.86 & & & & & \\
\hline & Plant Cost & $\$ / k W$ & 2,140 & $15.0 \%$ & $18.0 \%$ & $22.6 \%$ & $100 \%$ & \\
\hline & Production Well Cost & SK/well & 4,918 & & & & & \\
\hline & Injector Well Cost & SK/well & 4,918 & & & & & \\
\hline & Surface Equipment Cost & SK/well & 100 & & & & & \\
\hline & Exploration Success & Ratio & 0.80 & & & & & \\
\hline & Confirmation Success & Ratio & 0.80 & & & & & \\
\hline & Stimulation Cost & \$K/well & 750 & & & & & \\
\hline & Production Well Flow Rate & $\mathrm{gpm} / \mathrm{well}$ & 332 & & & & & \\
\hline & Temperature Drawdown Rate & $\% /$ year & $3.00 \%$ & & & & & \\
\hline & Annual O\&M non-labor & $\%$ & $3.5 \%$ & & & & & \\
\hline & Number of O\&M staff & $\#$ & 14.6 & & & & & \\
\hline \multirow{13}{*}{$\begin{array}{l}\text { TIO 23- } \\
\text { Automation/Enhance } \\
\text { d Controls }\end{array}$} & Utilization Factor & $\%$ & $95 \%$ & & & & & \\
\hline & Brine Effectiveness & W-h/lb & 10.86 & & & & & \\
\hline & Plant Cost & $\$ / \mathrm{kW}$ & 2,140 & & & & & \\
\hline & Production Well Cost & SK/well & 4,918 & & & & & \\
\hline & Injector Well Cost & SK/well & 4,918 & & & & & \\
\hline & Surface Equipment Cost & SK/well & 100 & & & & & \\
\hline & Exploration Success & $\begin{array}{ll}\text { Ratio } \\
\end{array}$ & 0.80 & & & & & \\
\hline & Confirmation Success & Ratio & 0.80 & & & & & \\
\hline & Stimulation Cost & \$K/well & 750 & & & & & \\
\hline & Production Well Flow Rate & $\mathrm{gpm} / \mathrm{well}$ & 332 & & & & & \\
\hline & Temperature Drawdown Rate & $\%$ \%/year & $3.00 \%$ & & & & & \\
\hline & \begin{tabular}{|l} 
Annual O\&M non-labor \\
\end{tabular} & $\%$ & $3.5 \%$ & & & & & \\
\hline & Number of O\&M staff & $\#$ & 14.6 & $40.0 \%$ & $50.0 \%$ & \begin{tabular}{l|l|l|}
$62.5 \%$ & -1
\end{tabular} & $100 \%$ & \\
\hline \multirow{13}{*}{ Sum of TIOs } & Utilization Factor & $\%$ & $95 \%$ & & & $0.0 \%$ & & Cap value at $100 \%$ for Util Factor for combined impacts of TIO $19,21,22$ and 23 (put if statements into model \\
\hline & Brine Effectiveness & W-h/lb & \begin{tabular}{c|c|c|}
50.86 \\
\end{tabular} & $15.0 \%$ & $20.0 \%$ & \begin{tabular}{|l|l|}
$30.0 \%$ \\
\end{tabular} & $100 \%$ & Cap value at $25 \%$ improvement \\
\hline & Plant Cost & $\$ / k \mathrm{~W}$ & 2,140 & $15.0 \%$ & $18.0 \%$ & $22.6 \%$ & $100 \%$ & Cap value at $50 \%$ improvement \\
\hline & Production Well Cost & SK/well & 4,918 & $12.0 \%$ & $0.0 \%$ & $28.0 \%$ & $75 \%$ & Mulitplicative combination of \% improvements as per Chip Mansure suggestion \\
\hline & Injector Well Cost & SK/well & 4,918 & $12.0 \%$ & $0.0 \%$ & $28.0 \%$ & $75 \%$ & Mulitplicative combination of $\%$ improvements as per Chip Mansure suggestion \\
\hline & Surface Equipment Cost & \$K/well & 100 & $0.0 \%$ & $0.0 \%$ & $0.0 \%$ & & \\
\hline & Exploration Success & Ratio & 0.80 & $21.0 \%$ & $28.0 \%$ & $35.0 \%$ & $70 \%$ & Cap value at $95 \%$, if it goes over limit, prorate new amount back to each TIO. \\
\hline & Confirmation Success & Ratio & 0.80 & $20.9 \%$ & $27.8 \%$ & $34.8 \%$ & $70 \%$ & Cap value at $95 \%$, if it goes over limit, prorate new amount back to each TIO. \\
\hline & Stimulation Cost & \$K/Well & 750 & $0.0 \%$ & $0.0 \%$ & $0.0 \%$ & & Cap value at $75 \%$ improvement \\
\hline & Production Well Flow Rate & $\mathrm{gpm} / \mathrm{well}$ & 332 & $24.0 \%$ & $32.0 \%$ & $40.0 \%$ & $85 \%$ & \\
\hline & Temperature Drawdown Rate & \%/year & $3.00 \%$ & $21.5 \%$ & $28.6 \%$ & $35.8 \%$ & $85 \%$ & Cap value at $75 \%$ improvement \\
\hline & Annual O\&M non-labor & $\%$ & $1.5 \%$ & $46.4 \%$ & $58.0 \%$ & $72.5 \%$ & $100 \%$ & Cap value at $40 \%$ improvement \\
\hline & Number of O\&M staff & \# & 14.6 & $40.0 \%$ & $50.0 \%$ & $62.5 \%$ & $100 \%$ & Cap value at $50 \%$ improvement \\
\hline
\end{tabular}


Appendix F: Cumulative Probability Distribution Functions of LCOE by Case

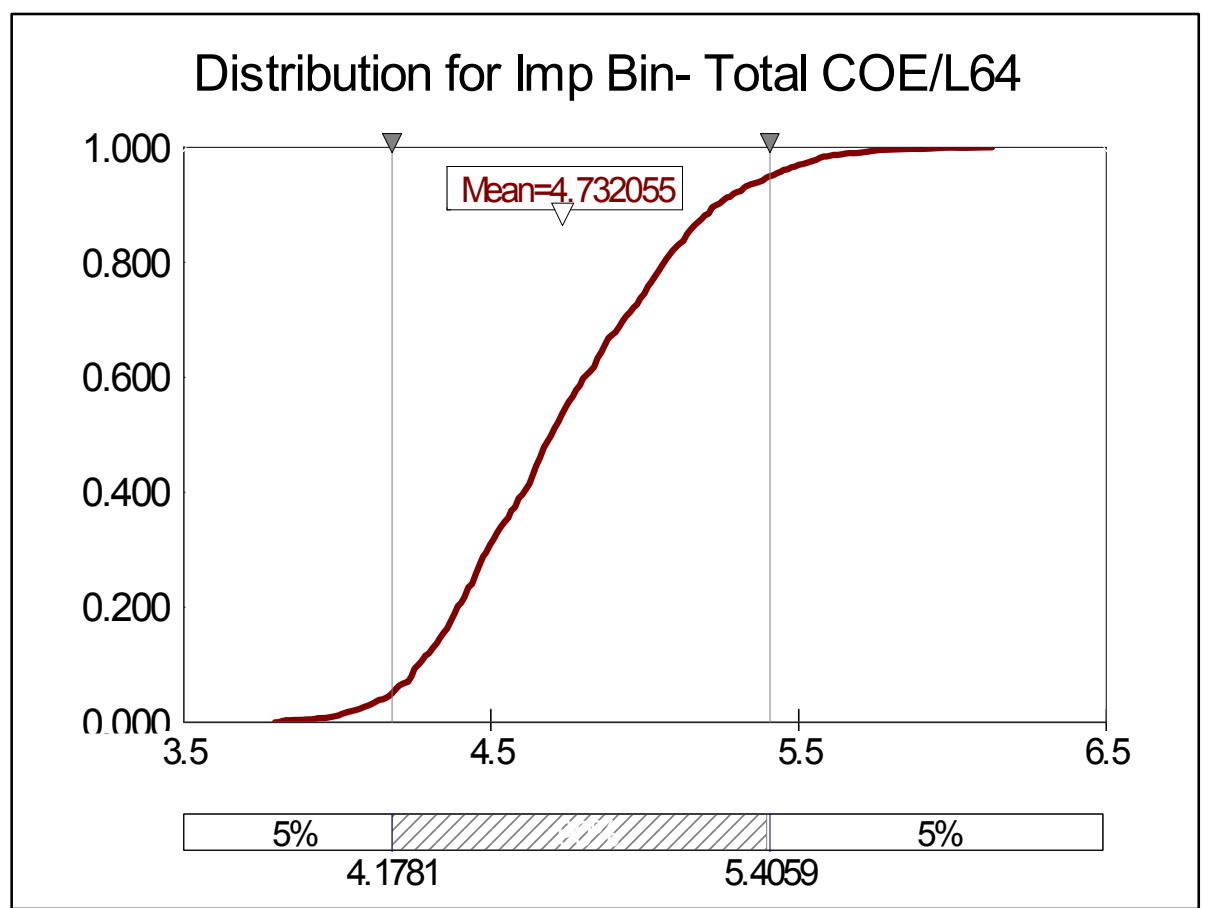

Figure F1. Hydrothermal Binary 2010 Experts Case LCOE ( $\phi / k W h)$

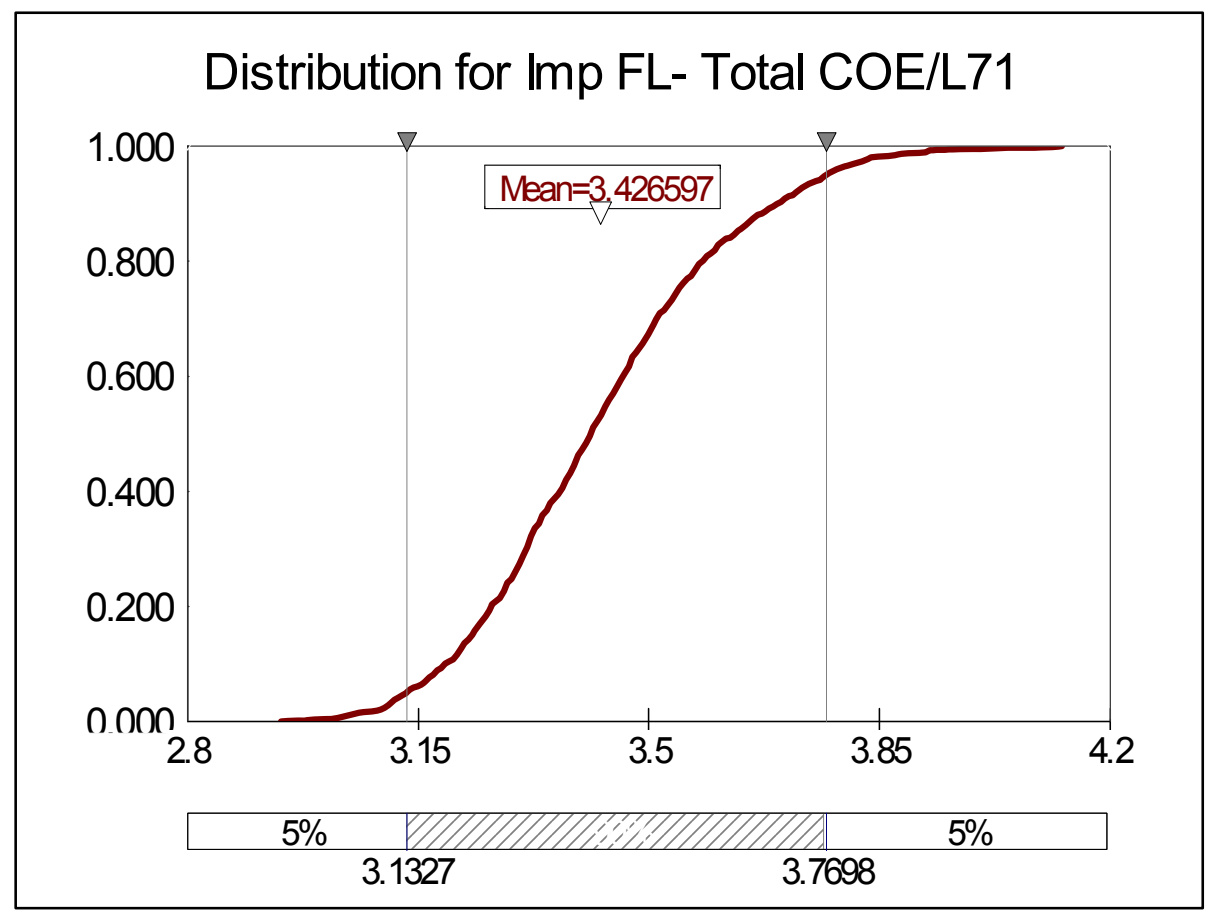

Figure F2. Hydrothermal Flash 2010 Experts Case LCOE ( $\phi / k W h)$ 


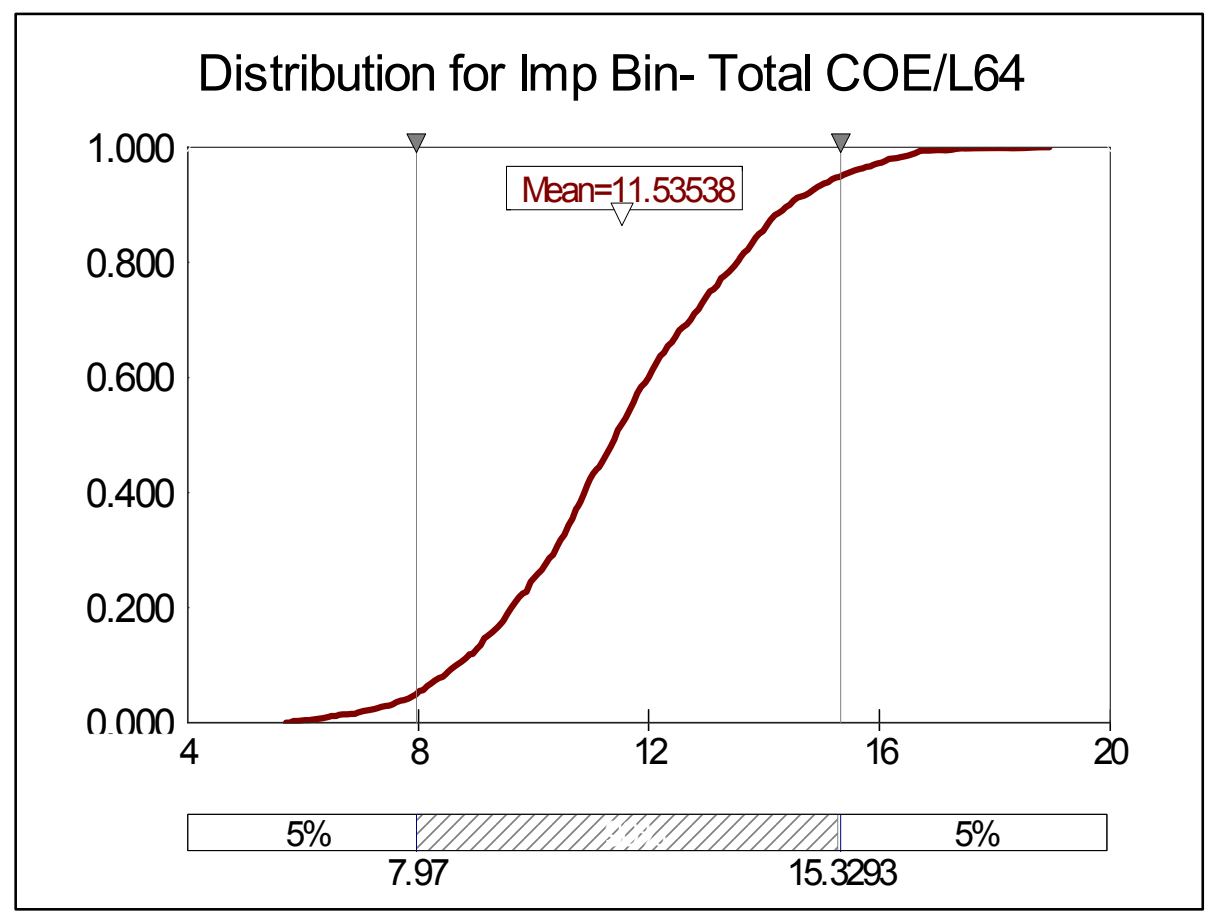

Figure F3. EGS Binary 2010 Experts Case LCOE ( $\phi / \mathrm{kWh})$

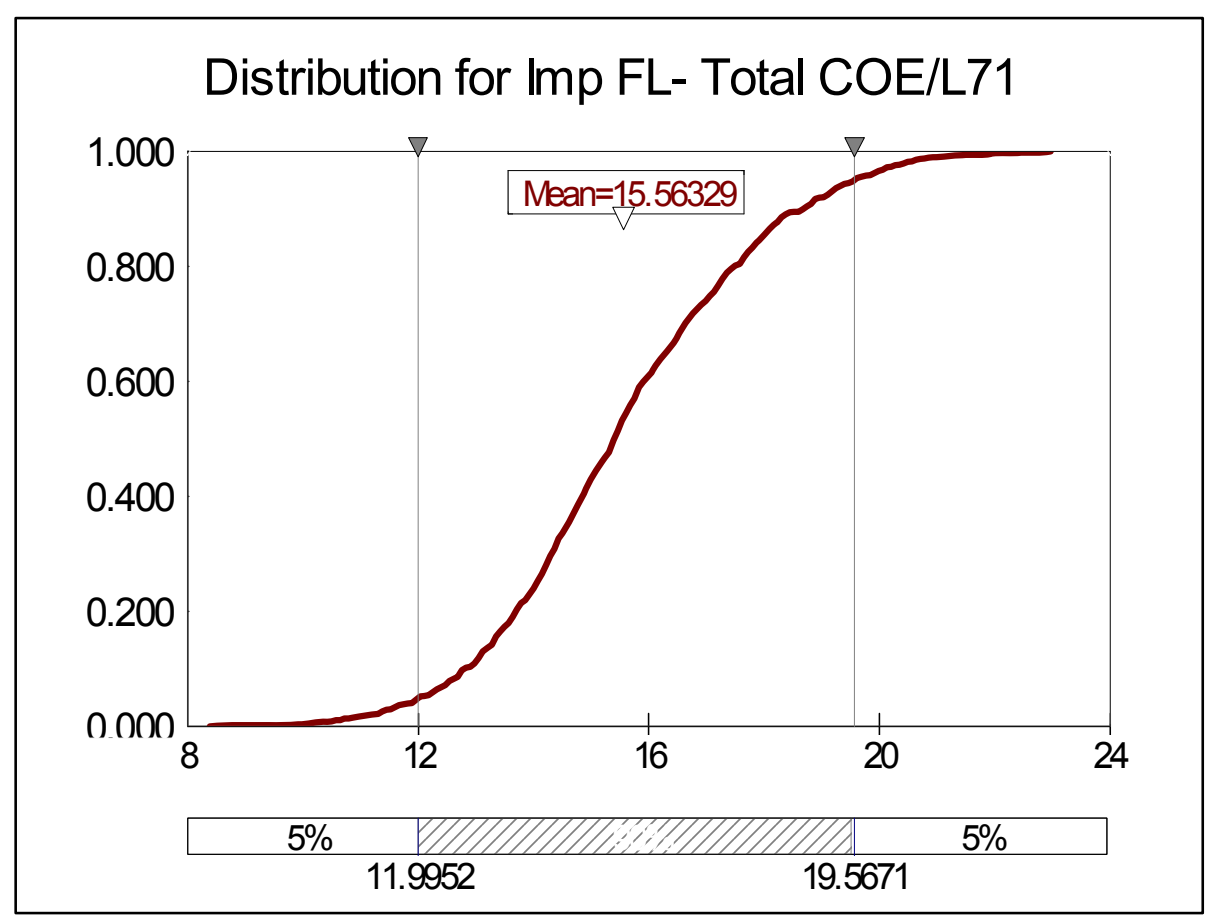

Figure F4. EGS Flash 2010 Experts Case LCOE ( $\phi / k W h)$ 


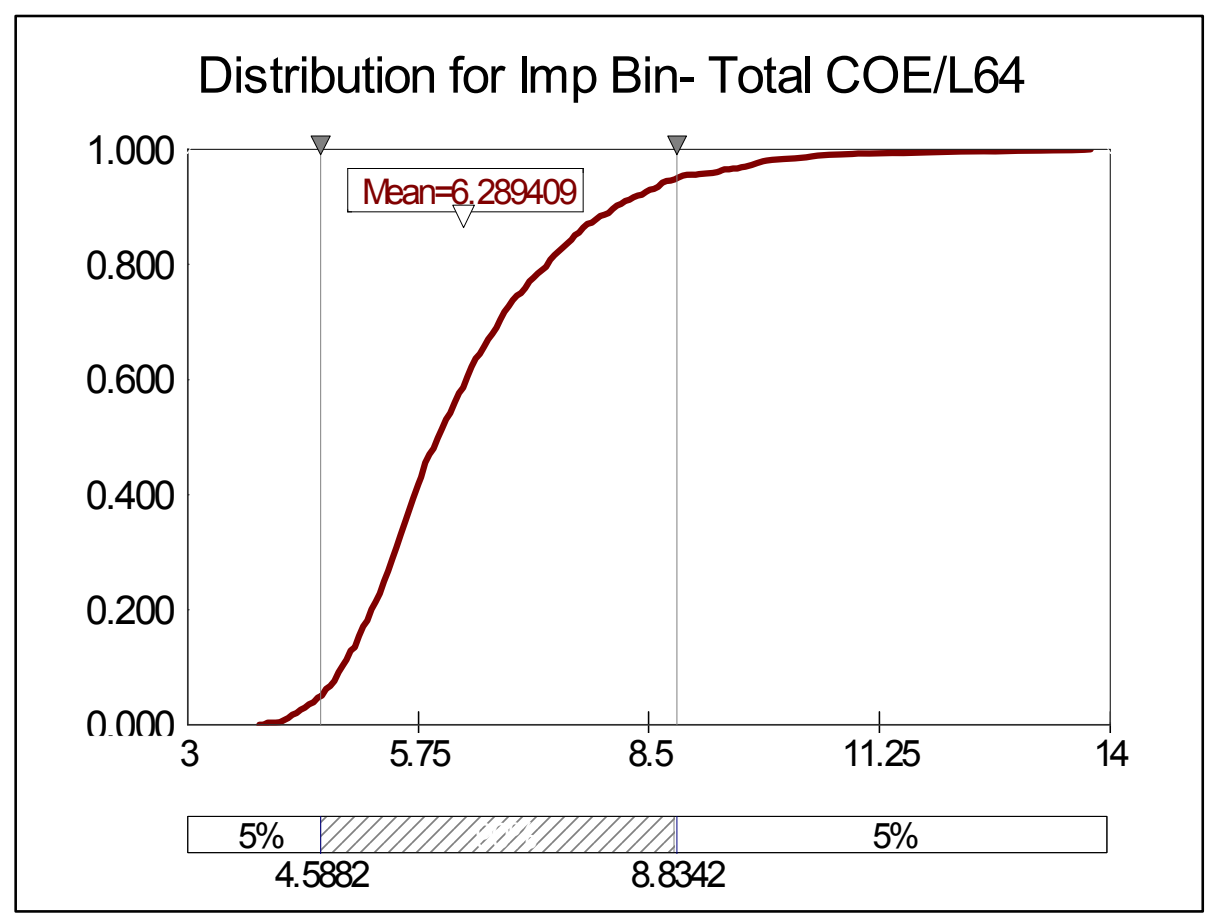

Figure F5. Evolutionary EGS Binary 2040 Experts Case LCOE ( $\phi / k W h)$ 


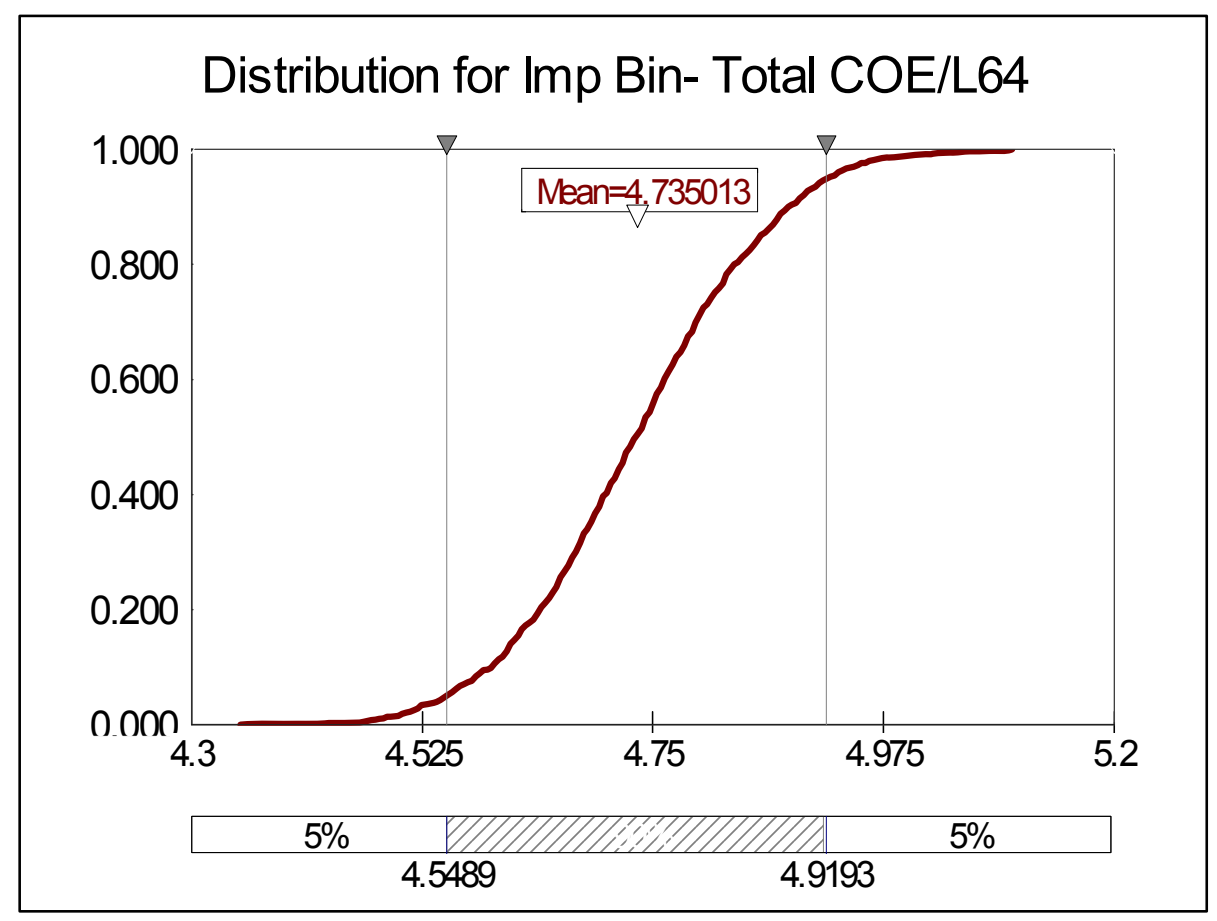

Figure F6. Hydrothermal Binary 2010 MYPP Case LCOE ( $\phi / k W h)$

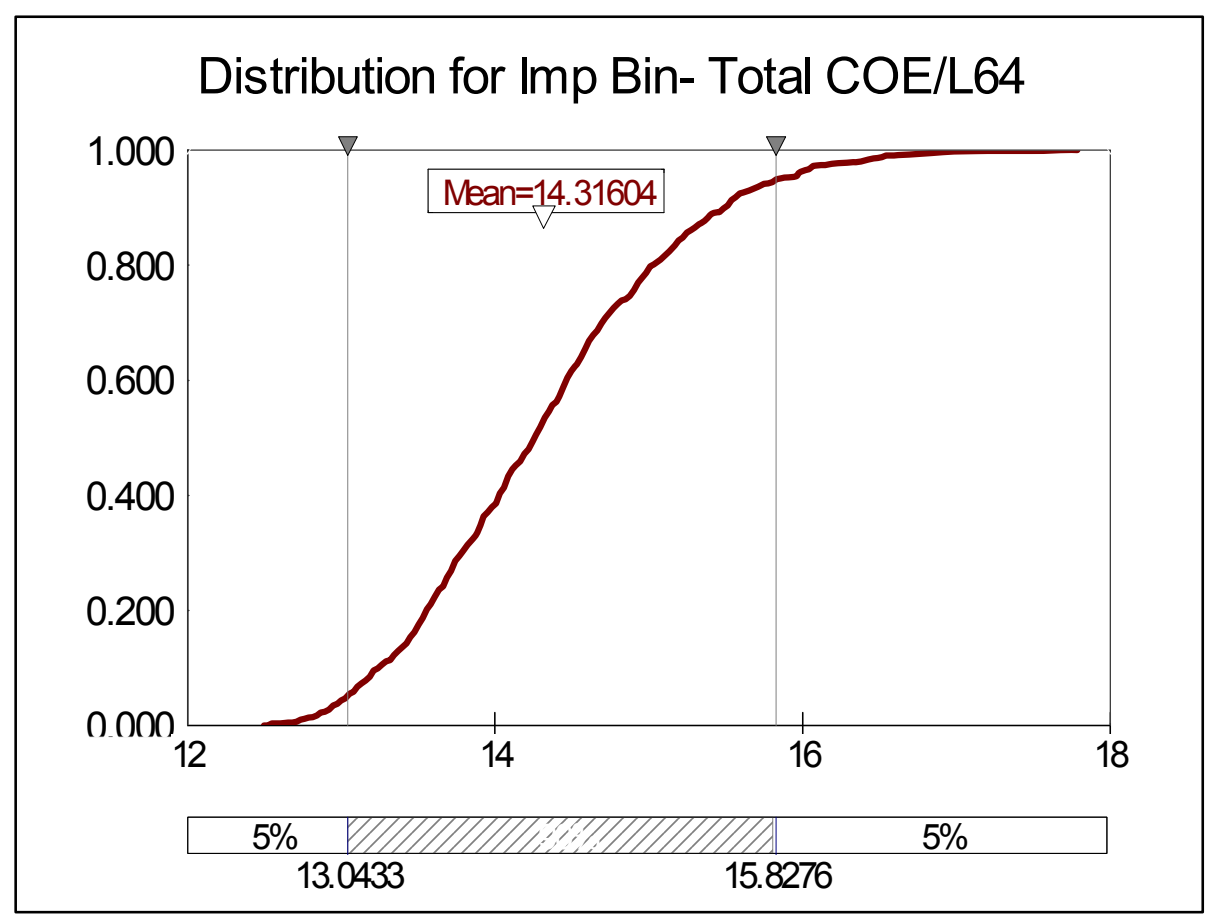

Figure F7. EGS Binary 2010 MYPP Case LCOE ( $\phi / k W h)$ 


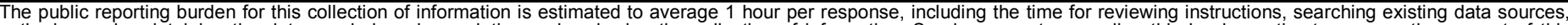

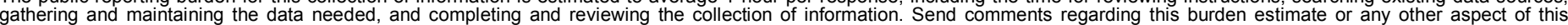

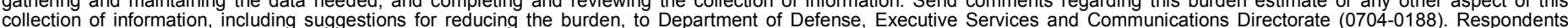

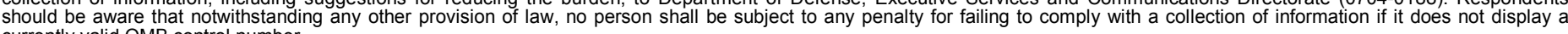

PLEASE DO NOT RETURN YOUR FORM TO THE ABOVE ORGANIZATION.

\begin{tabular}{l|l|l|l} 
1. REPORT DATE $(D D-M M-Y Y Y Y)$ & 2. REPORT TYPE & 3. DATES COVERED (FrOm - TO)
\end{tabular}

March 2007

Technical Report

4.
TITLE AND SUBTITLE
Preliminary Technical Risk Analysis for the Geothermal

Technologies Program

5a. CONTRACT NUMBER

DE-AC36-99-GO10337

5b. GRANT NUMBER

5c. PROGRAM ELEMENT NUMBER

6. AUTHOR(S)

J. McVeigh and J. Cohen (PERI);

M. Vorum, G. Porro, and G. Nix (NREL) 5d. PROJECT NUMBER

NREL/TP-640-41156

5e. TASK NUMBER

GT04.1101

5f. WORK UNIT NUMBER
7. PERFORMING ORGANIZATION NAME(S) AND ADDRESS(ES)

National Renewable Energy Laboratory

1617 Cole Blvd.

Golden, CO 80401-3393

9. SPONSORING/MONITORING AGENCY NAME(S) AND ADDRESS(ES)
8. PERFORMING ORGANIZATION REPORT NUMBER

NREL/TP-640-41156
10. SPONSOR/MONITOR'S ACRONYM(S) NREL

11. SPONSORING/MONITORING AGENCY REPORT NUMBER

12. DISTRIBUTION AVAILABILITY STATEMENT

National Technical Information Service

U.S. Department of Commerce

5285 Port Royal Road

Springfield, VA 22161

\section{SUPPLEMENTARY NOTES}

\section{ABSTRACT (Maximum 200 Words)}

This report explains the goals, methods, and results of a probabilistic analysis of technical risk for a portfolio of R\&D projects in the DOE Geothermal Technologies Program (The "Program"). The analysis is a task by Princeton Energy Resources International, LLC (PERI), in support of the National Renewable Energy Laboratory (NREL) on behalf of the Program. The main challenge in the analysis lies in translating R\&D results to a quantitative reflection of technica risk for a key Program metric: levelized cost of energy (LCOE). This requires both computational development (i.e., creating a spreadsheet-based analysis tool) and a synthesis of judgments by a panel of researchers and experts of the expected results of the Program's R\&D.

\section{SUBJECT TERMS}

NREL; geothermal; Geothermal Technologies Program; risk analysis; research; levelized cost of energy; LCOE; Geothermal Electric Technology Evaluation Model; GETEM; technology improvement opportunities; PERI; Princeton Energy Resources International

\begin{tabular}{|c|c|c|c|c|}
\hline \multicolumn{3}{|c|}{ 16. SECURITY CLASSIFICATION OF: } & \multirow{2}{*}{$\begin{array}{l}\text { 17. LIMITATION } \\
\text { OF ABSTRACT } \\
\text { UL }\end{array}$} & \multirow{2}{*}{$\begin{array}{l}\text { 18. NUMBER } \\
\text { OF PAGES }\end{array}$} \\
\hline $\begin{array}{l}\text { a. REPORT } \\
\text { Unclassified }\end{array}$ & $\begin{array}{l}\text { b. ABSTRACT } \\
\text { Unclassified }\end{array}$ & $\begin{array}{l}\text { c. THIS PAGE } \\
\text { Unclassified }\end{array}$ & & \\
\hline
\end{tabular}

\begin{tabular}{l} 
19a. NAME OF RESPONSIBLE PERSON \\
19b. TELEPHONE NUMBER (Include area code) \\
\hline
\end{tabular}

